Historic, archived document

Do not assume content reflects current scientific knowledge, policies, or practices. 



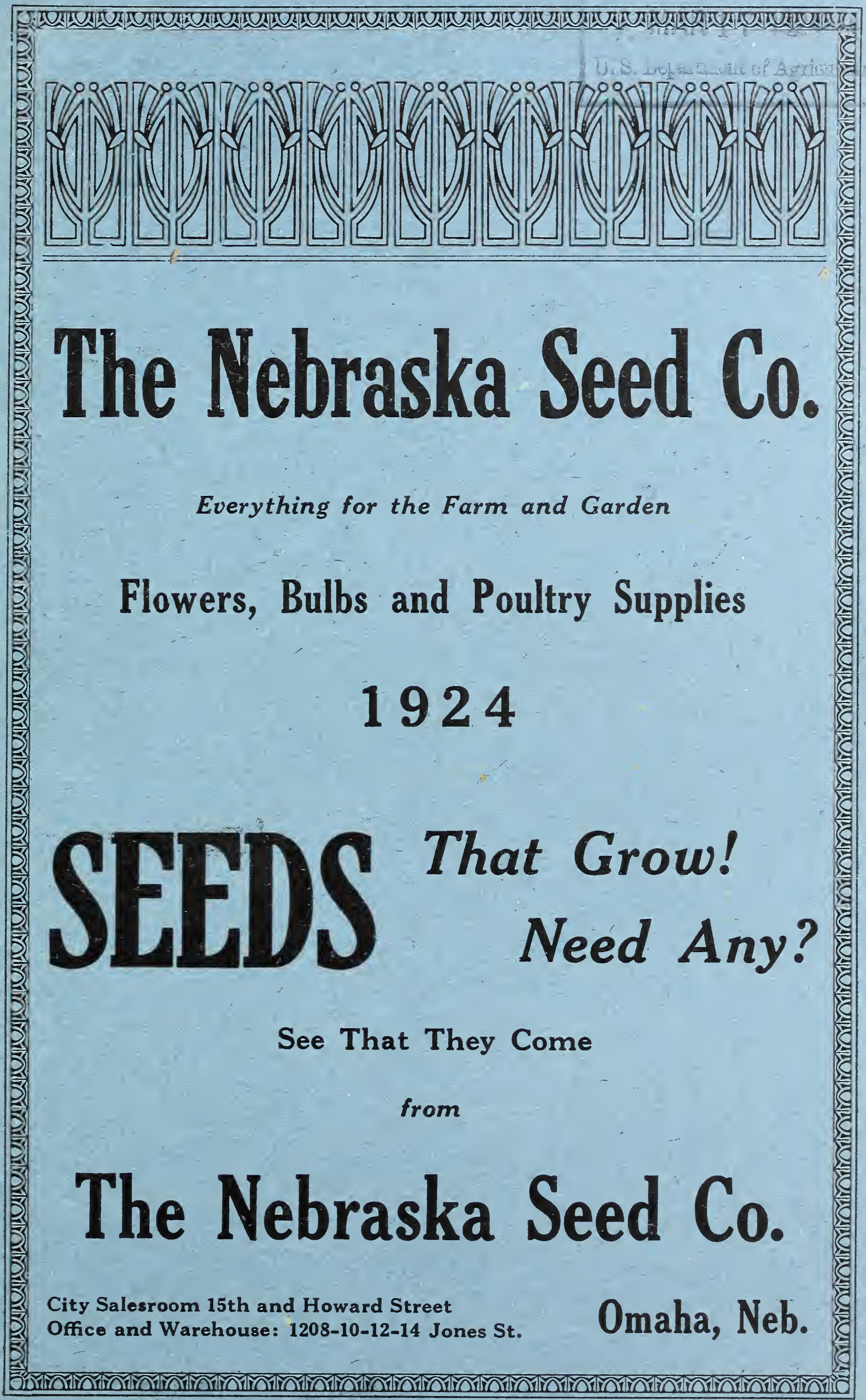




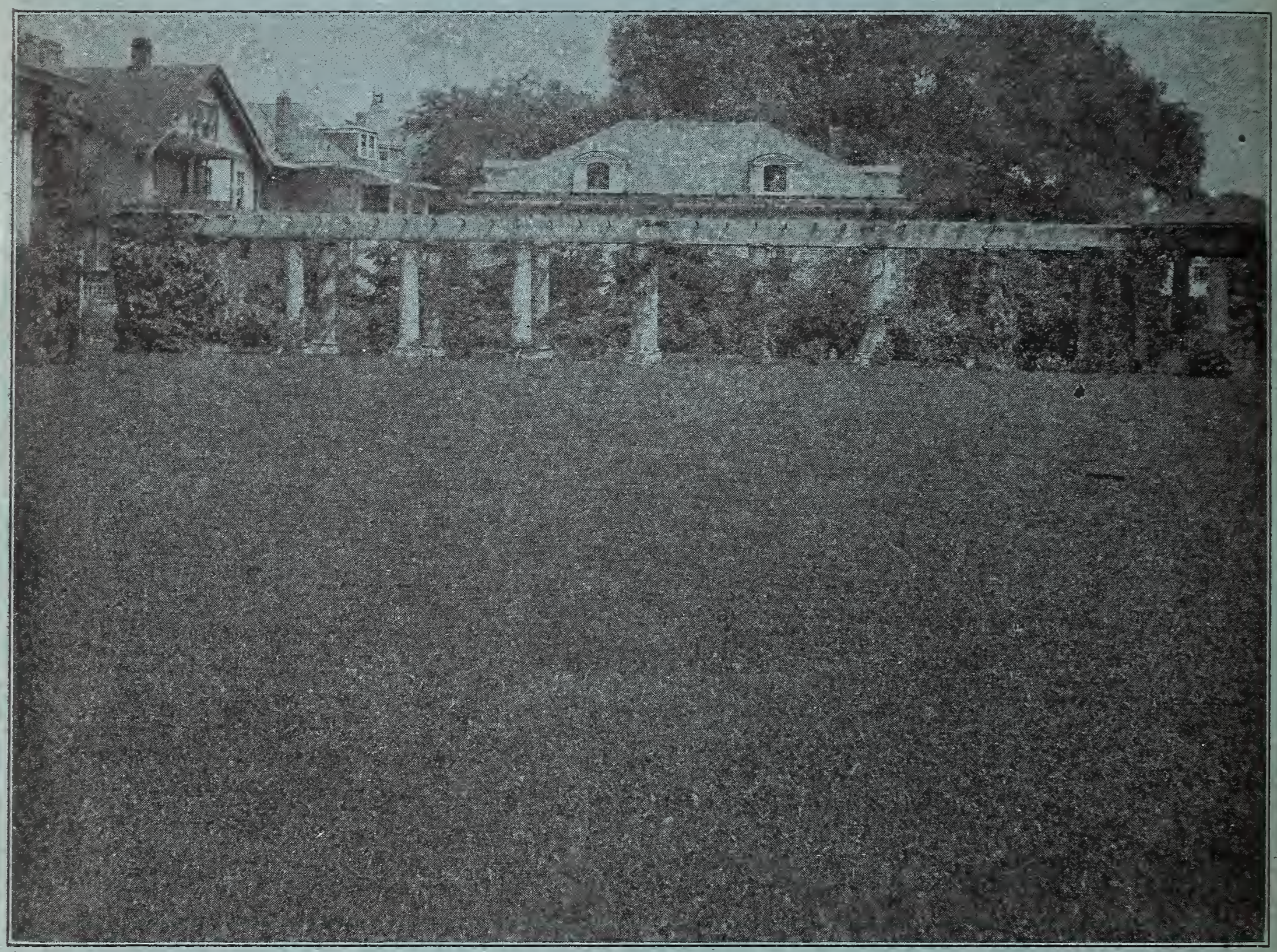

\section{THE LAWN}

PREPARING A D I A NUIING TII GBOUND. First a thorough preparation of the soil is absulutely necessary: If the soil is not naturally rich it should be well fertilized. Pulverized Sheep Manure applied at the rate of one ton to the acre is especially recommended. Plow deep (spading is better), then pulverize, rake and roll until a smooth even surface is obtained.

SOWING THE SEED, ROIIING AND WEEDIrG. In the latitude of Omaha sow seed in March, April or May, but earlier in the season if vou can prepare the soil and sow the better The seed can be sown in September and produce a fine lawn. For small plots sow one pound for each 300 square feet. For large lawns, golf links, tennis, cricket and croquet grounds, use $100 \mathrm{lbs}$ per acre. When the seed is sown, rake it in lightly and after that give it a thorough rolling if possible, so as to have an even surface. Annual weeds, natural to the soil, will appear before the young grass becomes established; none of these should be allowed to ripen their seeds.

TO GRASS A BAIK OR TERIACE. For each square rod, take a pound of lawn grass seed and mix it thoroughly with 6 cubic feet of good, dry garden loam; place in a tub, and adr lia manure, diluted with about two-thirds of water. so as to bring the whole to the consistency of mortar. The slope must be made perfectly smooth, and then well watered, after which the paste should be applied.

CUTPING, FEEDING AND WATERING. When the gress has attained height of 4 inches it should be mown, care being exercised not to cut it too close. Frequent rolling and mowing will make the turf close and compact, strengthen the grass and render the lawn smooth and attractive Lawns require frequent feeding and watering to keep up their vigor.

\section{TRANS-MISSISSIPPI LAWN MIXTURE.}

Will produce a permanent and beautiful lawn wherever sown.

Our Trans-Mississippi Mixture is the result of several years' careful experimenting, and, as we now offer it, is unequalled. This mixture consists of fourteen different kinds of grasses, ane is composed of the best varieties for producing in the shortest possible time, a thick inter-wove carpet of the deepest green color and most las:ing quality. It will not burn out brown in the hottest weather and will not require re-seeding for vears. The quantity required for making nen lawns is 100 lbs, per acre, or for renovating old lawns one to two bushels. For a plot $15 \times 20$, or 300 square feet, one quart is required for new or one pint for renovation.

\section{THE NEBRASKA'S SEED CO.'S "SHADY NOOK" LAWN SEED}

This is especially prepared for shady places under trees and for light sandy soil where it is difficult to get a stand of grass.

\section{KENTUCKY BLUE GRASS}

Many prefer this to a mixture of grasses, and the fact cannot be denied that a lawn of Blue Grass is magnificent; it takes longer, however, to get it established.

\section{WHITE CLOVER}

For Lawns-Fine and Pure. 


\section{CONDENSED PRICE LIST \\ OF \\ Garden and Farm Seeds}

Description of all Varieties in Catalogue. For Larger Quantities Please ask for Special Prices.

ASPARAGUS

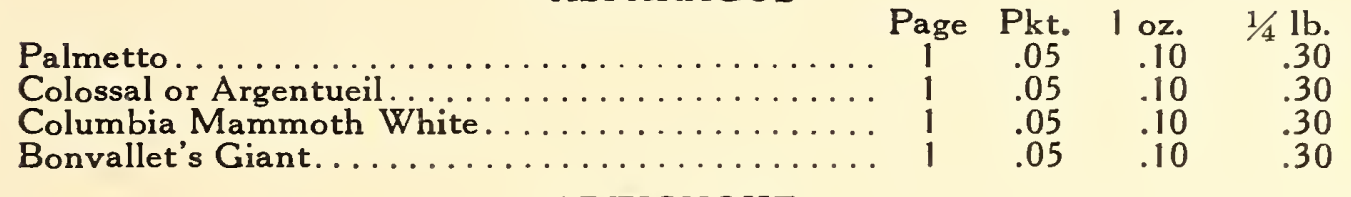

\section{ARTICHOKE}

Large Green Globe BEANS-Green Podded Varieties

Full Measure. . Page 1 lb. 2 lbs.

Burpee's Stringless Green Pod

Early Bountiful

Tennessee Green Pod... .

Giant Stringless Valentine

Early Red Valentine.

Long Yellow Six Weeks.

White Navy.

\section{BEANS Wax Podded Varieries}

Davis Kidney Wax

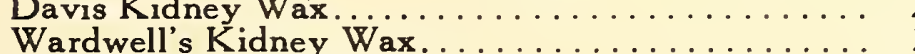

Round Pod Kidney Wax.

Pencil Pod Black Wax

New Hodson Wax.

lmproved Golden Wax.

Rust Proof Golden Wax.

Royal Purple Wax.

Unrivalled Wax

BEANS-Bush Lima

New Wonder Bush Lima...............

Dreer's Bush Lima....................... 3

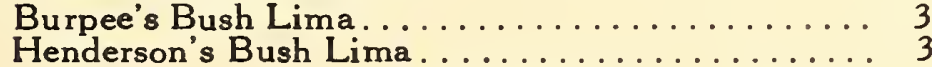

BEANS-Pole or Running

Dutch Case Knife.......................

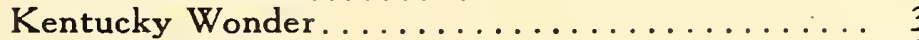

Lazy Wife.

Scarlet Runner.

King of the Garden Lima.

Cut Short or Corn Hill.

Early Jersey Lima.

BRUSSEL'S SPROUTS

Improved Dwarf

\section{BEETS-Garden}

Crosby's Egyptian.

$\begin{array}{rrr}\text { lb. } & 2 \text { lbs. } & 5 \text { lbs. } \\ .30 & .55 & 1.25 \\ .35 & .65 & 1.50 \\ .30 & .55 & 1.25 \\ .30 & .55 & 1.25 \\ .30 & .55 & 1.25 \\ .30 & .55 & 1.25 \\ .30 & .55 & 1.25 \\ .25 & .45 & 1.10\end{array}$

Eclipse.

Detroit Dark Red.

Extra Early Egyptian

Early Blood Turnip.

Edmand's Blood Turni

Long Smooth Blood.

Swiss Chard Lucullus

BEETS-Mangel

Danish Sludstrup.

Giant Half Rose Sugar . . . . . . . . . . . . . . . . . .

Giant Eckendorf

Mammoth Long Red

Golden Tankard

Mammoth Long Yellow.

$\begin{array}{lll}.30 & .55 & 1.25 \\ .30 & .55 & 1.25 \\ .30 & .55 & 1.25 \\ .30 & .55 & 1.25 \\ .30 & .55 & 1.25 \\ .30 & .55 & .1 .25 \\ .30 & .55 & 1.25 \\ .30 & .55 & 1.25 \\ .35 & .65 & 1.50 \\ .35 & .65 & 1.50\end{array}$

BEETS-Sugar

Vilmorin's Improved.

Klein Wanzleben.

Lane's Imperial. 
SWEET CORN-Medium Early Sorts

Page $1 \mathrm{lb} .2$ lbs. 5 lbs.

Crosby's Early ..................... 10 .25

White Mexican...................... $10 \quad .30$

Shaker's Large Early.................... $10 . .25$

$\begin{array}{lr}45 & 1.00 \\ & 1.25\end{array}$

Black Mexican.................. $10 \quad \begin{array}{llll}.30 & .55 & 1.25\end{array}$

SWEET CORN Late and Main Crop Varieties

Stowell's Evergreen.................. 10

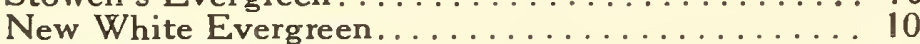

Golden Evergreen...

$.25 \quad .45$

$.45 \quad 1.00$

Country Gentlemen.

\section{CHICKORY}

Large Rooted Magdeburg.

Whitloof.

\section{CORN SALAD}

Large Leaved

CRESS

Curled or Pepper Crass.

\section{CRESS}

True Water Cress.

\section{CABBAGE}

Copenhagen.

Early Jersey Wakefield

$10 \quad .30$

1.00

Early Spring

Henderson's Early Summer . . . . . . . . . . . .

Charleston Wakefield.

Suc cession.

All Seasons.

Surehead

Premium Late Flat Dutch . . . . . . . . . . . . . .

St. Louis Late Market.

Danish Ball-Head.

Large Late Drumhead.

Danish Red Stonehead.

Mammoth Rock Red.

American Drumhead Savoy.

$\mathrm{Pe}$ Tsai or Chinese.

\section{CARROTS}

Early Chantenay.

Guerande or Oxheart.

$\ldots \ldots \ldots \ldots+7$

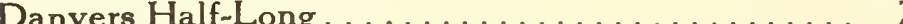

Early Scarlet Horn........................

Improved Long Orange. . . . . . . . . . . . . . 7

Giant White Belgian.

Giant Yellow Belgian.

\section{CAULIFLOWER}

Extra Early Snowball

Nebraska Market.

Extra Early Dwarf Erfurt. . . . . . . . . . . . .

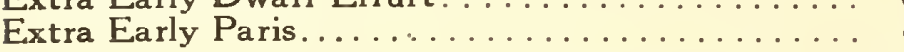

CELERY

White Plume.

Page Pkt. 1 oz. 1/4.lb

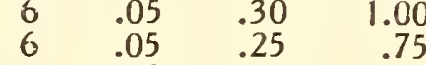

Golden Self-Blanching....................

Giant Pascal

Dwarf Golden Heart .........................

$\begin{array}{llr}.05 & .25 & .75 \\ .05 & .35 & 1.25 \\ .05 & .25 & .75 \\ .05 & .25 & .75\end{array}$

\section{CELERIAC}

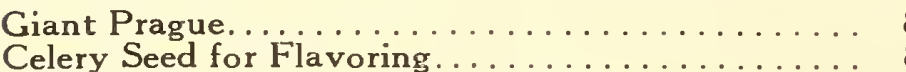

\section{CUCUMBERS}

Davis Perfect. . . . . . . . . . . . . . . . .

Klondike

Arlington White Spine.

Peerless White Spine

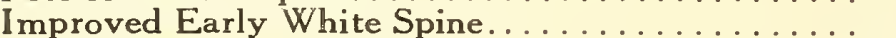

Cumberland. .

Fordhook Famous.

Japanese Climbing.

Chicago Pickling.

Snow's Pickling.

Cool and Crisp.

Early Russian.

Farly Cluster.

Farly Frame or Short

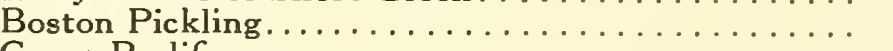

Green Prolific.

Improved Long Gireen.

\section{EGG PLANT}

Improved N.Y. Purple ................

Black Beauty....................... I

Florida High Bush................... 


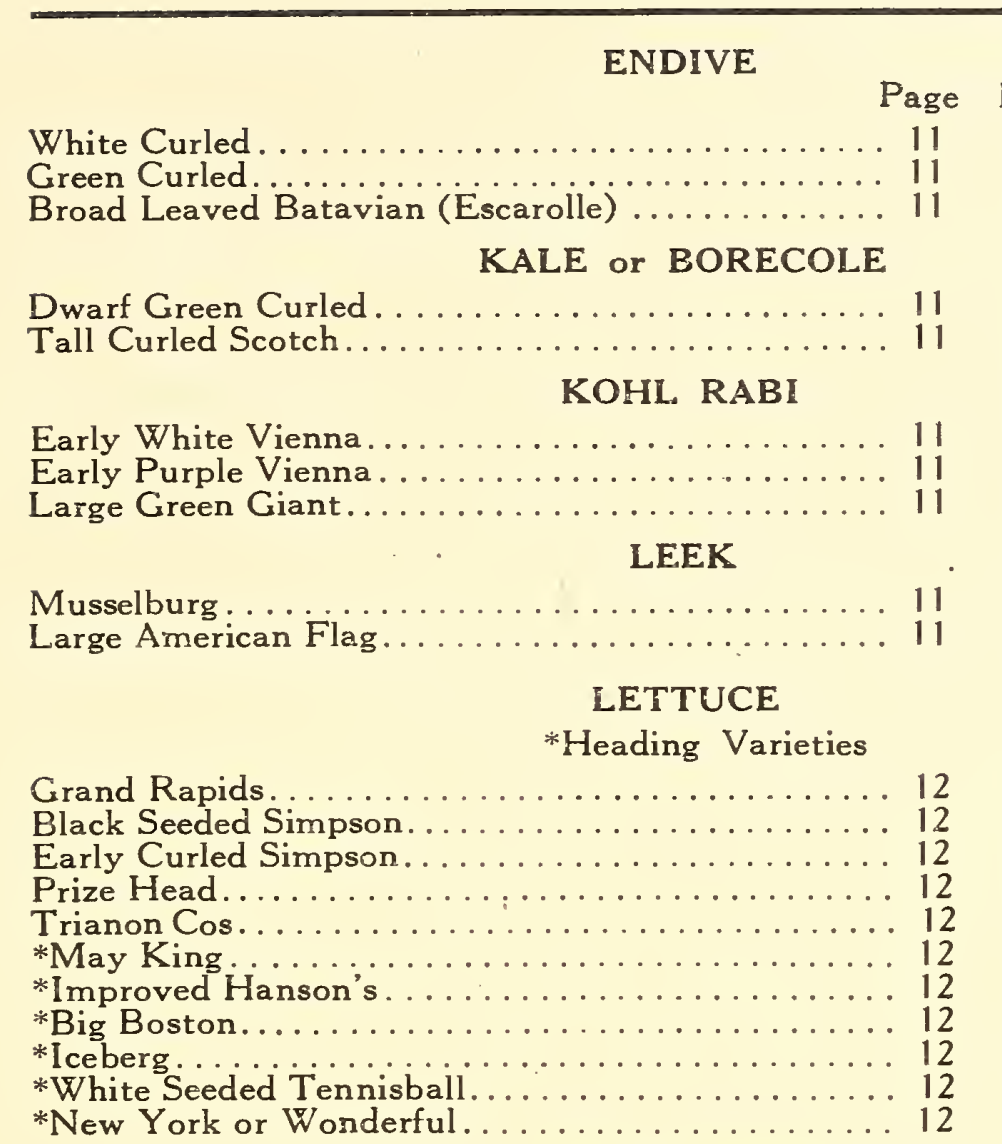

$\begin{array}{lrr} & & \\ & & \\ .05 & .10 & .35 \\ .05 & .10 & .35 \\ .05 & .10 & .35\end{array}$

$.05 \quad .20 \quad .75$

$\begin{array}{lll}.05 & .20 & .75 \\ .05 & .20 & .75 \\ .05 & .20 & .75\end{array}$

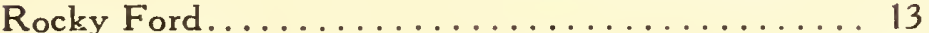

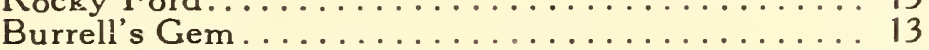

Nebraska Gold Lined........................... 13

Rocky Ford Salmon Tinted................ 13

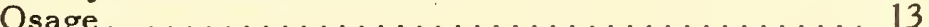

New Honey Dew. . . . . . . . . . . . . . . 13

Hackensack........................ 13

Long Yellow Cantaloupe................ 13

Prolific Nutmeg. ...................... 13

\section{MELON, WATER}

Tom Watson....................... 14

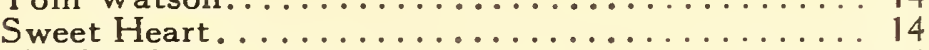

Kleckley's Sweet......................... 14

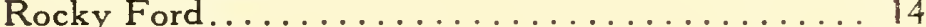

Cuban Queen........................ 14

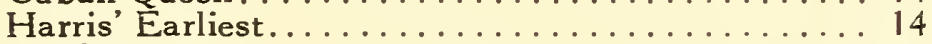

Cole's Early.......................... 14

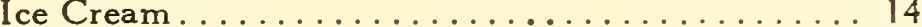

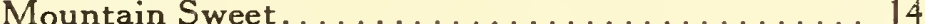

Phinney's Early..................... 14

Halbert's Honey..................... 14

Alabama Sweet...................... 14

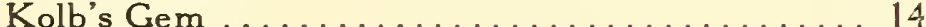

Vick's Early............................ 14

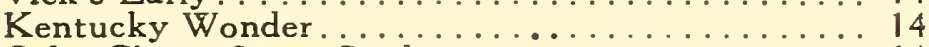

Colo. Citron Green Seed. ..................... 14

Colo. Citron Red Seed................... 14

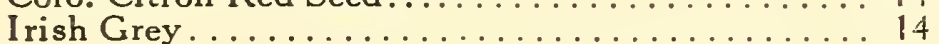

$\begin{array}{lll}.05 & .10 & .30 \\ .05 & .10 & .30 \\ .05 & .10 & .30 \\ .05 & .10 & .30 \\ .05 & .10 & .30 \\ .05 & .10 & .30 \\ .05 & .10 & .30 \\ .05 & .10 & .30 \\ .05 & .10 & .30 \\ .05 & .10 & .30 \\ .05 & .25 & .90\end{array}$

$\begin{array}{lll}.05 & .10 & .30 \\ .05 & .10 & .30 \\ .05 & .10 & .30 \\ .05 & .10 & .30 \\ .05 & .10 & .25 \\ .05 & .15 & .45 \\ .05 & .10 & .25 \\ .05 & .10 & .25 \\ .05 & .10 & .25\end{array}$

MUSTARD

Yellow or White London................. $11 \quad .05 \quad .10 \quad .25$

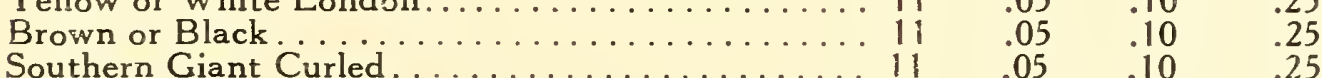

\section{OKRA or GUMBO}

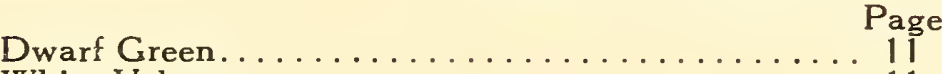

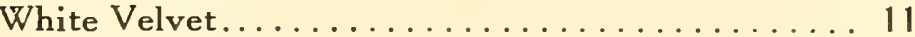

Tall Green Perkins........ 11

$\begin{array}{lll}.05 & .10 & .25 \\ .05 & .10 & .25 \\ .05 & .10 & .25 \\ .05 & .10 & .25 \\ .05 & .10 & .25 \\ .05 & .10 & .25 \\ .05 & .10 & .25 \\ .05 & .10 & .25 \\ .05 & .10 & .25 \\ .05 & .10 & .25 \\ .05 & .10 & .25 \\ .05 & .10 & .25 \\ .05 & .10 & .25 \\ .05 & .10 & .25 \\ .05 & .10 & .25 \\ .05 & .10 & .25 \\ .05 & .10 & .25 \\ .05 & .10 & .30\end{array}$

\section{ONIONS}

Southport Large Red Globe.................... 15

Southport Large White Globe............... 15

Large Red Wethersfield. . . . . . . . . . . . . . 15

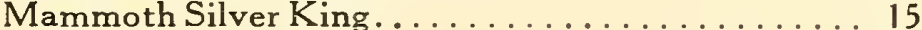

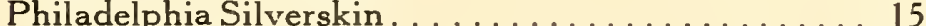

White Portugal

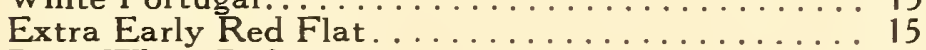

Paris White Pickling.................. 15

Prize Taker

Danvers Yellow Globe................... 15

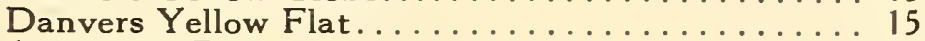

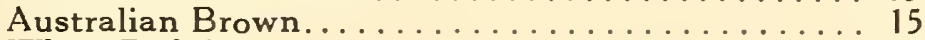

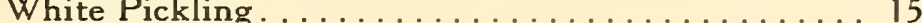

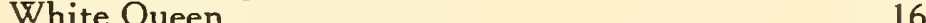

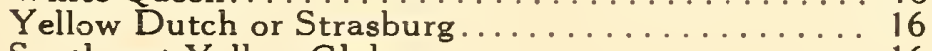

Southport Yellow Globe . ................... 16

$\begin{array}{lll}.05 & .20 & .60 \\ .05 & .25 & .75 \\ .05 & .20 & .60 \\ .05 & .25 & .75 \\ .05 & .20 & .60 \\ .05 & .20 & .60 \\ .05 & .20 & .60 \\ .05 & .25 & .75 \\ .05 & .20 & .60 \\ .05 & .20 & .60 \\ .05 & .20 & .60 \\ .05 & .20 & .60 \\ .05 & .20 & .60 \\ .05 & .25 & .75 \\ .05 & .20 & .60 \\ .05 & .20 & .60\end{array}$




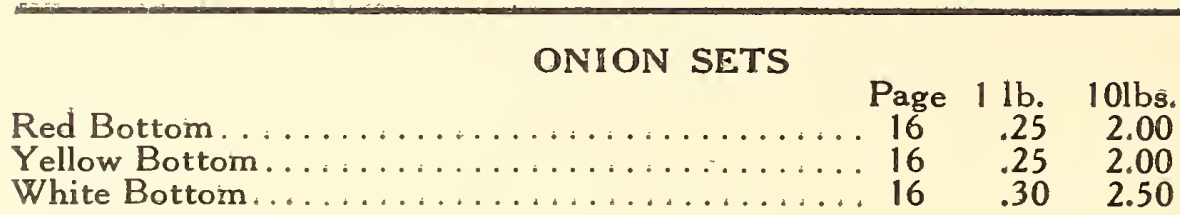

PARSNIP

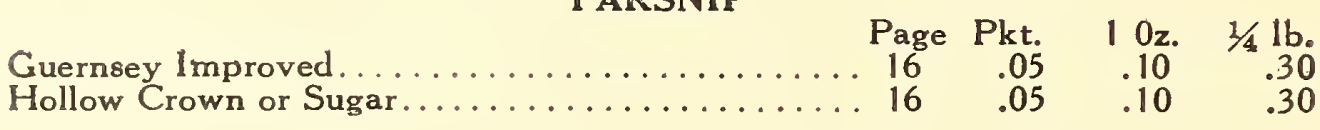

\section{PARSLEY}

Double Curled . ....................... 16

Champion Moss Curled................... 16

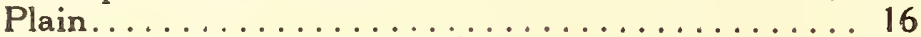

Hamburg or Turnip Rooted............. 16

$\begin{array}{lll}.05 & .10 & .30 \\ .05 & .10 & .30 \\ .05 & .10 & .30 \\ .05 & .10 & .30\end{array}$

\section{PEPPER}

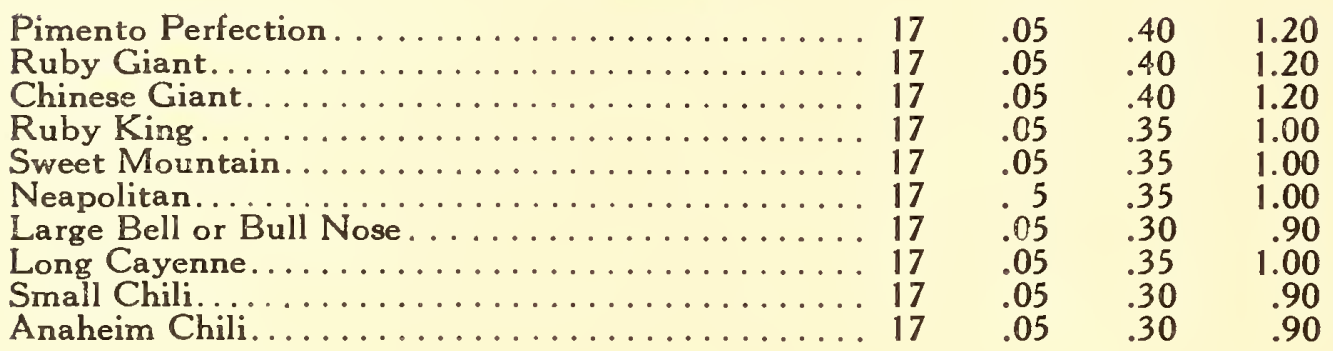

PEAS-Extra Early Varieties *Wrinkled Varieties

Nebraska Lightning.

Alaska or Earliest of All . . . . . . . . . . . . $\ldots \ldots$

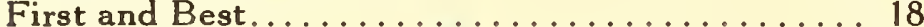

* Little Marvel .............. 18

*American Wonder.................... 18

*McLean's Little Gem..................... 18

Carter's Premium Gem.................. 18

*Gradus........................ 18

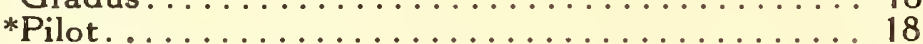

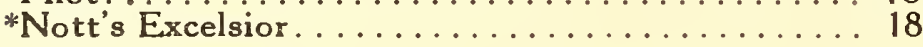

$\begin{array}{rrr}\text { llb. } & \text { 2 lbs. } & 5 \text { lbs } \\ .30 & .55 & 1.25 \\ .30 & .55 & 1.25 \\ .30 & .55 & 1.25 \\ .35 & .65 & 1.50 \\ .30 & .55 & 1.25 \\ .30 & .55 & 1.25 \\ .30 & .55 & 1.25 \\ .35 & .65 & 1.50 \\ .35 & .65 & 1.50 \\ .30 & .55 & 1.25\end{array}$

PEAS-Second Early Varieties

*Bliss Everbearing. ................... 18

*N. S. Co. Favorite.................... 18

\section{PEAS-Late or Main Crop Varieties}

*.Admiral Dewey........................... 19

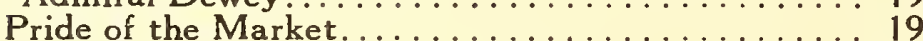

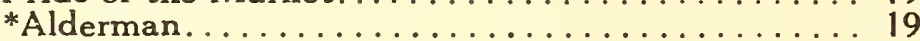

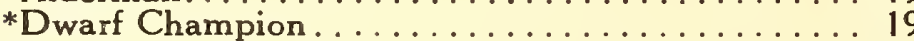

*Dwarf Telephone....................... 19

*Stratagem

*Improved Telephone.......................... 19

* Champion of England . . . . . . . . . . . . . . 19

Long Island Marrowfat. ................... 19

Large White Marrowfat. ............... 19

Black Eye Marrowfat.

$\begin{array}{lll}.35 & .65 & 1.50 \\ .30 & .55 & 1.25 \\ .35 & .65 & 1.50 \\ .30 & .55 & 1.25 \\ .35 & .65 & 1.50 \\ .30 & .55 & 1.25 \\ .30 & .55 & 1.25 \\ .30 & .55 & 1.25 \\ .30 & .55 & 1.25 \\ .25 & .45 & 1.00 \\ .25 & .45 & 1.00\end{array}$

PEAS-Edible Pod Sorts

Improved Sugar Marrow . . . . . . . . . . . . 19

Dwarf Gray Sugar....................... $19 \quad .35 \quad .65 \quad 1.50$

PUMPKIN

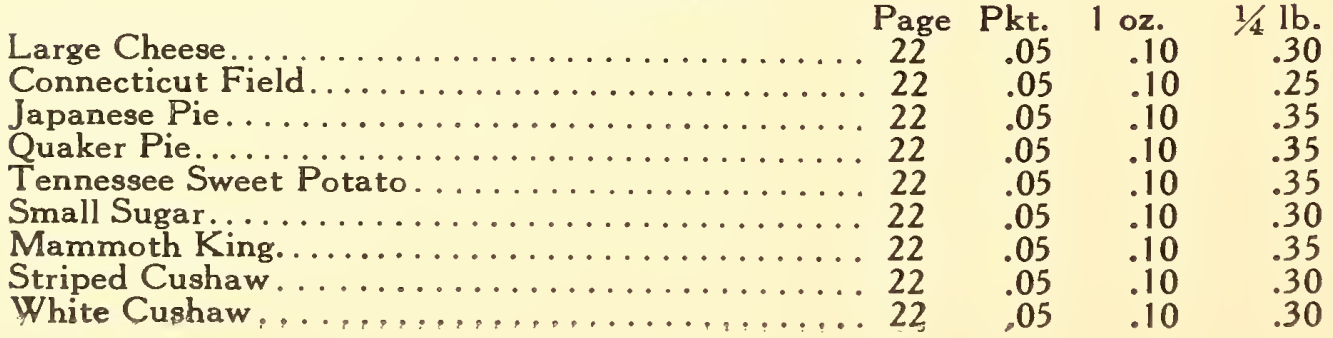




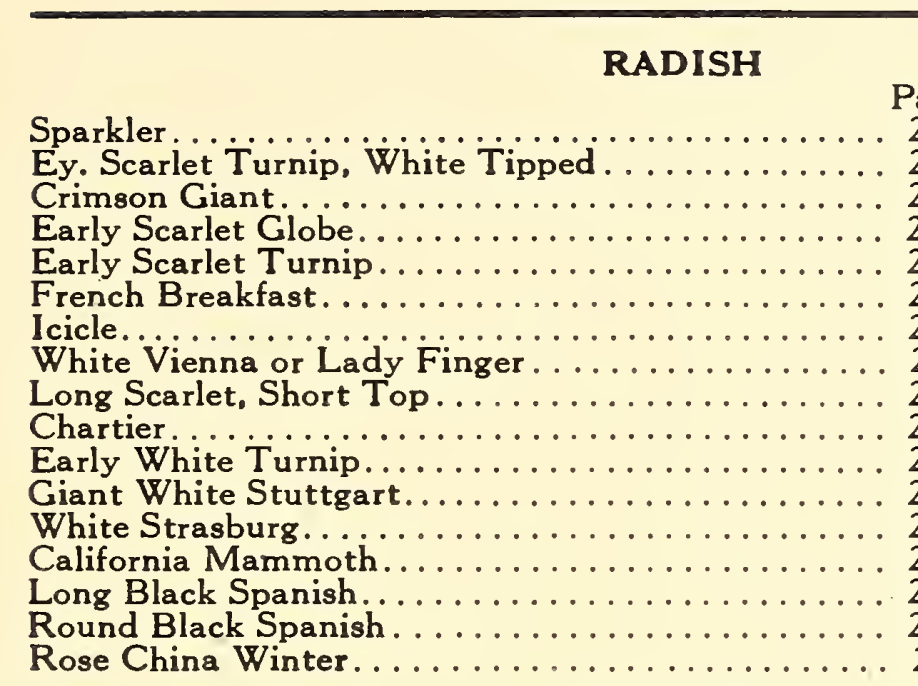

RHUBARB

Victoria. .......................... $21 \quad .05 \quad .20 \quad .60$

RUTABAGA

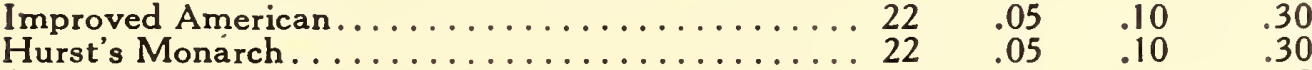

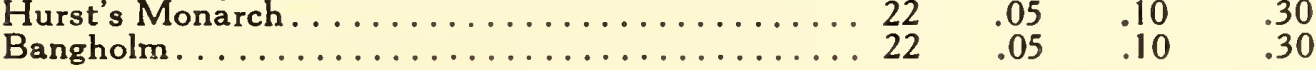

SALSIFY OR OYSTER PLANT

Mammoth Sandwich Island................ $17 \quad .05 \quad .20 \quad .60$

\section{SQUASH}

Pike's Peak or Sibley.................. 21

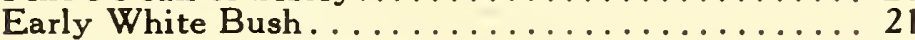

Chicago Warted Hubbard ................. 2

Improved Hubbard ..................... 2

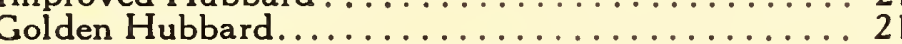

Mammoth Summer Crookneck............... 2

Delicata.

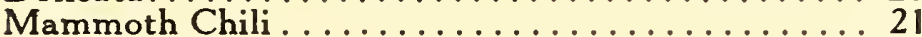

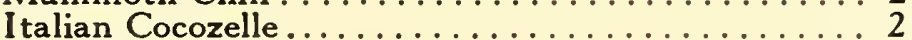

Marblehead......................... 21

SPINACH

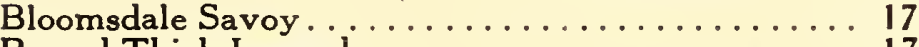

Round Thick Leaved...................... 17

Long Standing Prickly.................. 17

King of Denmark, new

TURNIP

Extra Early White Milan ................ 22

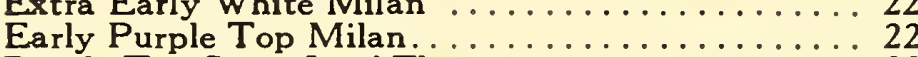

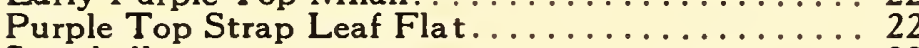

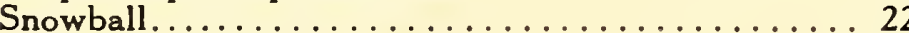

Purple Top White Globe.................. 22

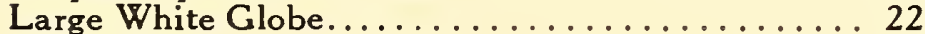

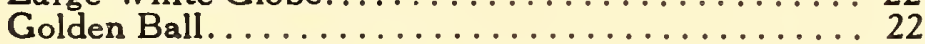

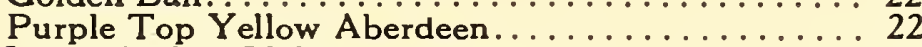

Large Amber Globe..................... 22

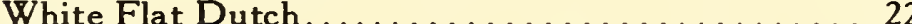

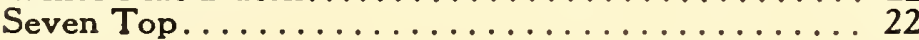

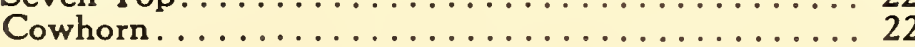

$\begin{array}{rrr}\text { Pkt. } & 1 \text { oz. } & 1 / 4 \text { lb } \\ .05 & .10 & .30 \\ .05 & .10 & .25 \\ .05 & .10 & .25 \\ .05 & .10 & .25 \\ .05 & .10 & .25 \\ .05 & .10 & .25 \\ .05 & .10 & .25 \\ .05 & .10 & .25 \\ .05 & .10 & .25 \\ .05 & .10 & .25 \\ .05 & .10 & .25 \\ .05 & .10 & .25 \\ .05 & .10 & .25 \\ .05 & .10 & .25 \\ .05 & .10 & .25 \\ .05 & .10 & .25 \\ .05 & .10 & .25\end{array}$

$\begin{array}{lll}.05 & .15 & .40 \\ .05 & .15 & .40 \\ .05 & .15 & .40 \\ .05 & .15 & .40 \\ .05 & .15 & .40 \\ .05 & .15 & .40 \\ .05 & .15 & .40 \\ .05 & .15 & .40 \\ .05 & .15 & .40 \\ .05 & .15 & .40\end{array}$

TOMATO

Earliana............................ 23

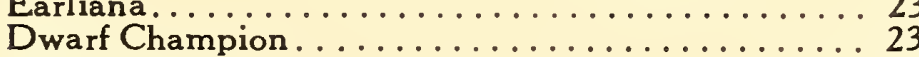

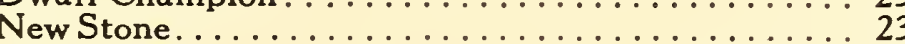

Early Detroit....................... 23

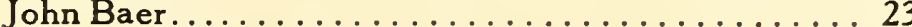

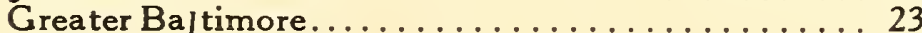

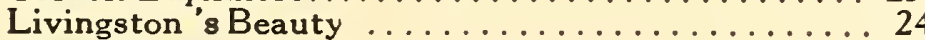

Dwarf Stone. . . . . . . . . . . . . . . . . . 24

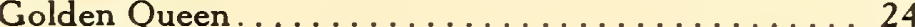

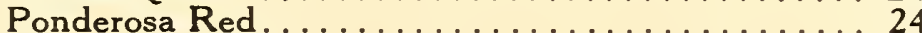

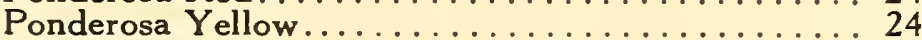

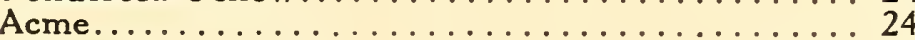

Livingston's Globe ................... 24

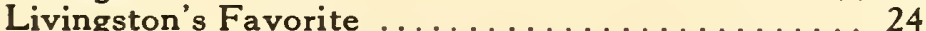

Livingston's Perfection .................. 24

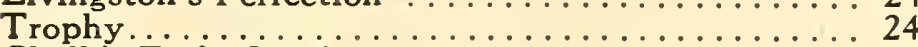

Chalk's Early Jewel. . . . . . . . . . . . . . . 24

June Pink . . . . . . . . . . . . . . . . . . . 24

Red Cherry....................... 24

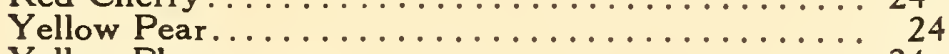

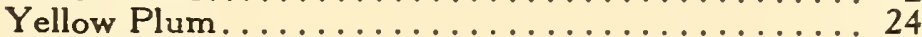

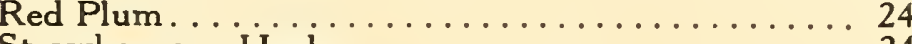

Strawberry or Husk................... 24

$\begin{array}{lll}.05 & .10 & .25 \\ .05 & .10 & .25 \\ .05 & .10 & .25 \\ .05 & .15 & .40\end{array}$

$\begin{array}{lll}.05 & .15 & .50 \\ .05 & .15 & .50 \\ .05 & .10 & .30 \\ .05 & .10 & .30 \\ .05 & .10 & .30 \\ .05 & .10 & .30 \\ .05 & .10 & .30 \\ .05 & .10 & .30 \\ .05 & .10 & .30 \\ .05 & .10 & .30 \\ .05 & .10 & .30 \\ .05 & .10 & .30\end{array}$

$\begin{array}{lll}.05 & .35 & 1.10 \\ .05 & .35 & 1.10 \\ .05 & .30 & 1.00 \\ .05 & .35 & 1.10 \\ .05 & .35 & 1.10 \\ .05 & .35 & 1.10 \\ .05 & .30 & 1.00 \\ .05 & .30 & 1.00 \\ .05 & .35 & 1.10 \\ .05 & .35 & 1.10 \\ .05 & .35 & 1.10 \\ .05 & .30 & 1.00 \\ .05 & .35 & 1.10 \\ .05 & .30 & 1.00 \\ .05 & .30 & 1.00 \\ .05 & .30 & 1.00 \\ .05 & .30 & 1.00 \\ .05 & .30 & 1.00 \\ .05 & .35 & 1.10 \\ .05 & .35 & 1.10 \\ .05 & .35 & 1.10 \\ .05 & .35 & 1.10 \\ .05 & .35 & 1.10\end{array}$




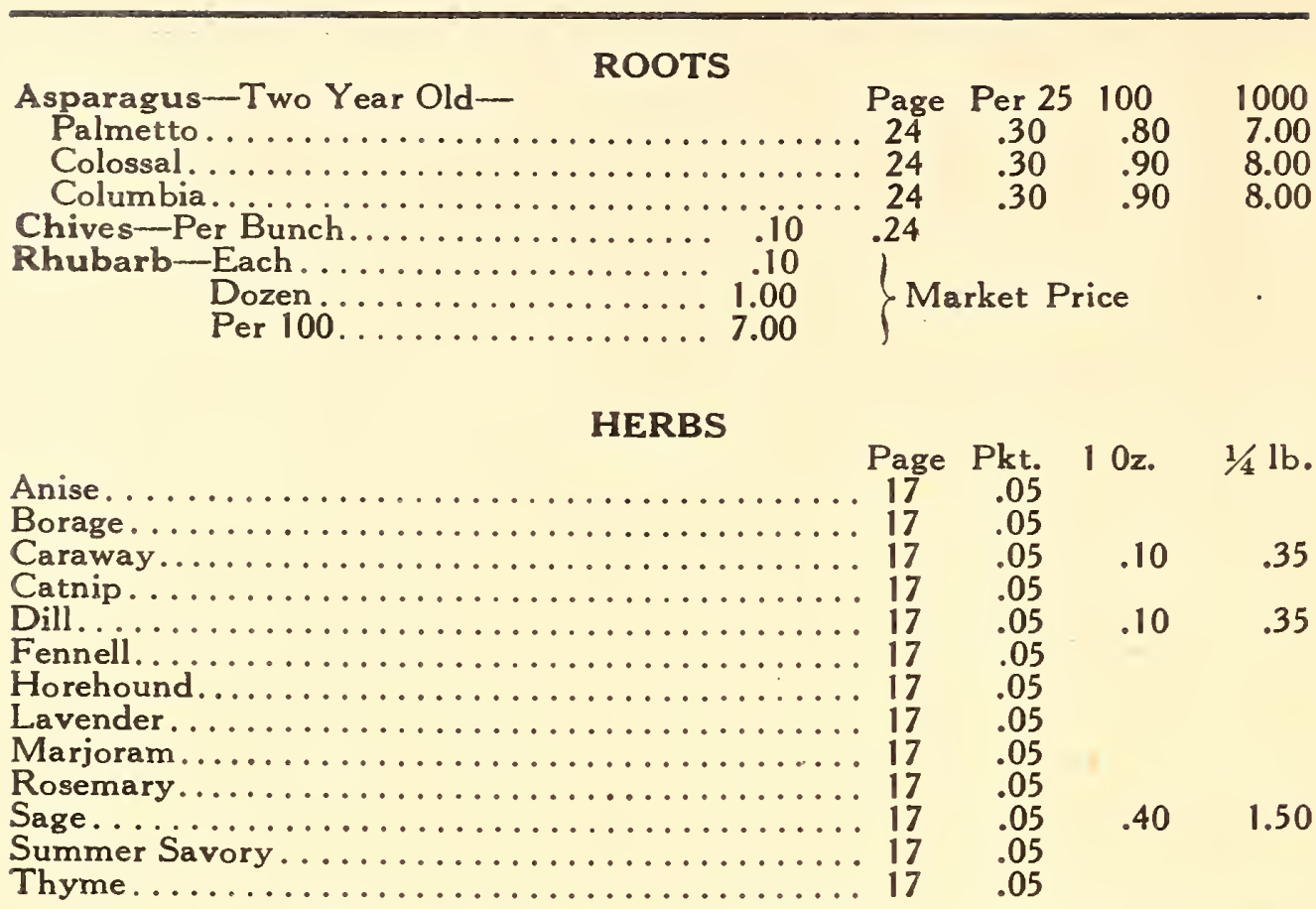

\section{Prices on Field and Grass Seed subject to market changes}

\section{NORTHERN GROWN SEED POTATOES}

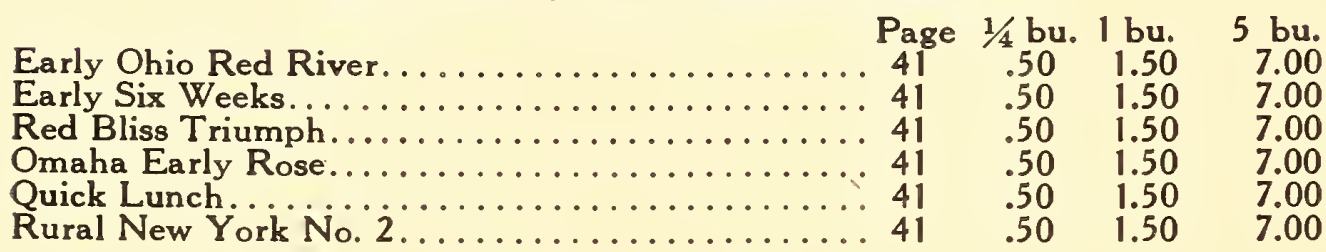

\begin{tabular}{|c|c|c|}
\hline 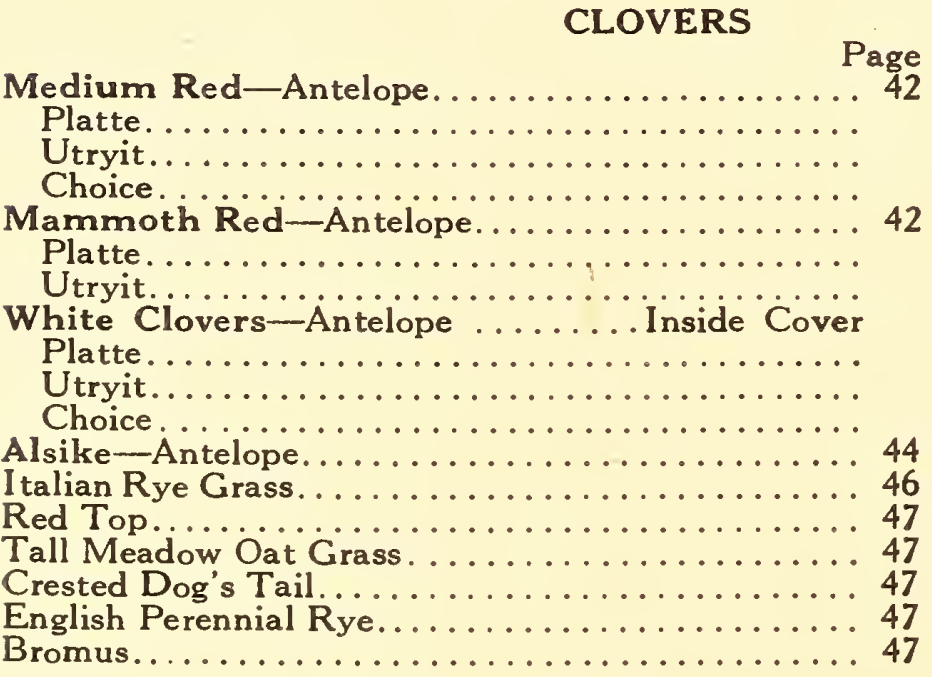 & $\begin{array}{ll}11 b . & 10 \\
.35 & 2.90 \\
.30 & 2.80 \\
.28 & 2.60 \\
.25 & 2.40 \\
.35 & 3.00 \\
.30 & 2.90 \\
.28 & 2.80 \\
.80 & 7.50 \\
.75 & 7.00 \\
.70 & 6.50 \\
.65 & 6.00 \\
.25 & 2.25 \\
.20 & 1.75 \\
.25 & 2.25 \\
.40 & 3.75 \\
.35 & 3.25 \\
.20 & 1.75 \\
.20 & 1.75\end{array}$ & $\begin{array}{l}001 \mathrm{lb} \\
27.50 \\
27.00 \\
25.00 \\
22.50 \\
28.00 \\
27.00 \\
21.00 \\
73.00 \\
68.00 \\
63.00 \\
60.00 \\
21.00 \\
16.50 \\
18.00 \\
35.00 \\
30.00 \\
16.00 \\
14.00\end{array}$ \\
\hline \multicolumn{3}{|l|}{ TIMOTHY } \\
\hline 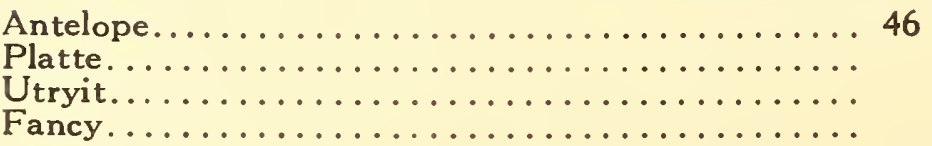 & $\begin{array}{r}1.25 \\
1.10 \\
1.00 \\
.95\end{array}$ & $\begin{array}{r}10.50 \\
10.00 \\
9.50 \\
9.00\end{array}$ \\
\hline
\end{tabular}

\section{SPECIAL GRASS SEED MIXTURES}

Trans-Mississippi Lawn . . . . . . . . . . . . . . . $48 \quad .50$

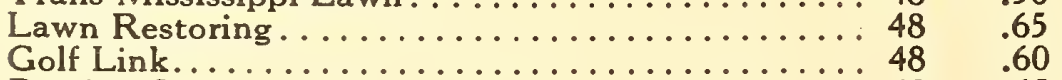

Putting Green.......................... 48

\section{MILLET}

German, Antelope.

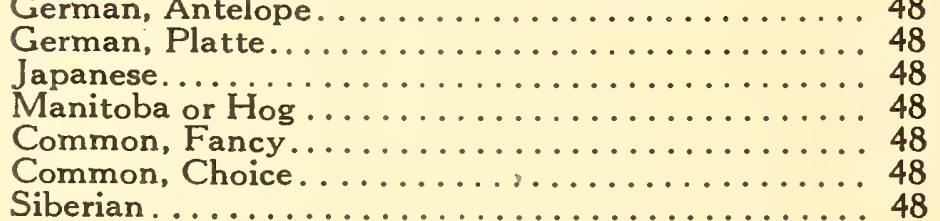

ALFALFA

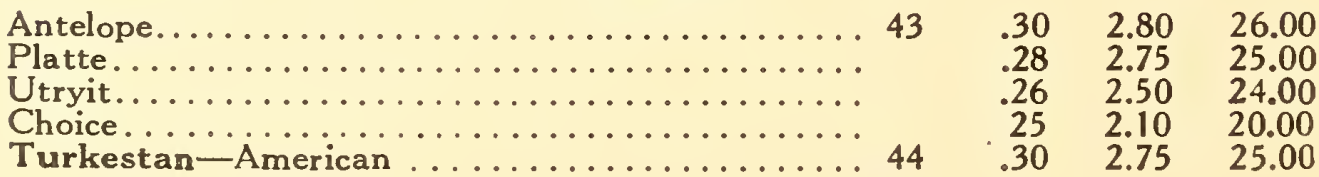




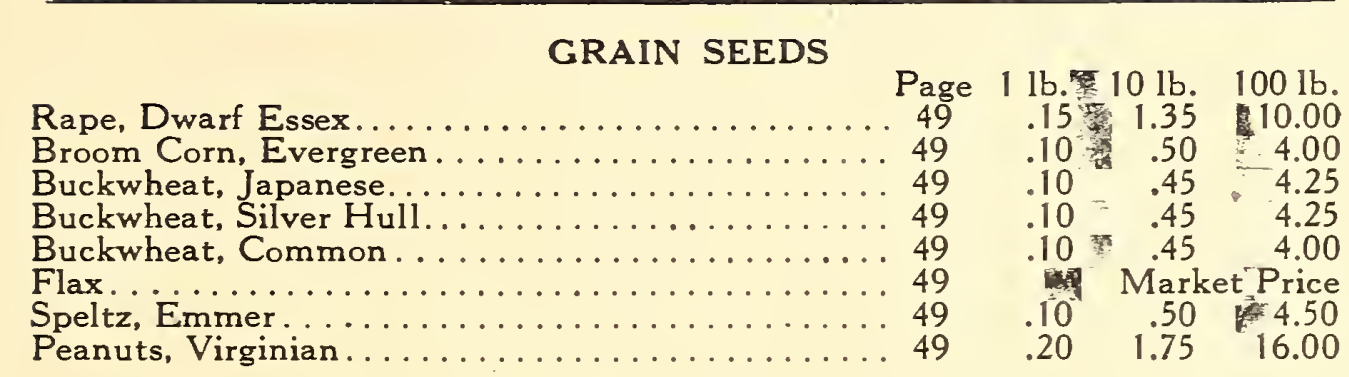

\section{COW PEAS}

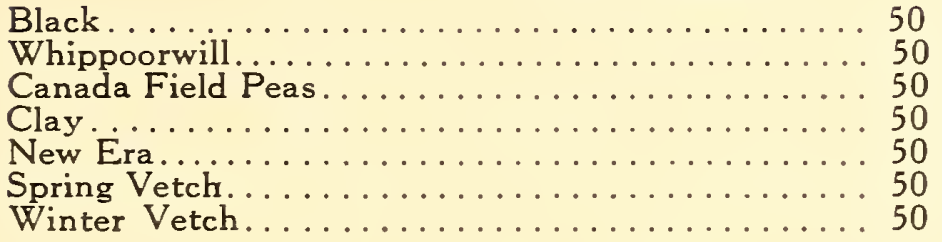

$\begin{array}{rrr}.10 & .70 & 6.50 \\ .10 & .70 & 6.50 \\ .10 & .70 & 6.50 \\ .10 & .70 & 6.50 \\ .10 & .70 & 6.50 \\ .15 & 1.25 & 10.00 \\ .25 & 2.00 & 18.00\end{array}$

SPRING WHEAT

Velvet Chaff Blue Stem . . . . . . . . . . . 51

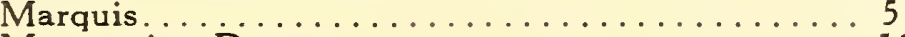

Macaroni or Durum.................... 51

BARLEY

Manshury....................51

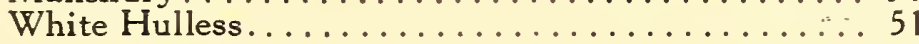

RYE

Winter.

5

Spring............................

\section{SORGHUM}

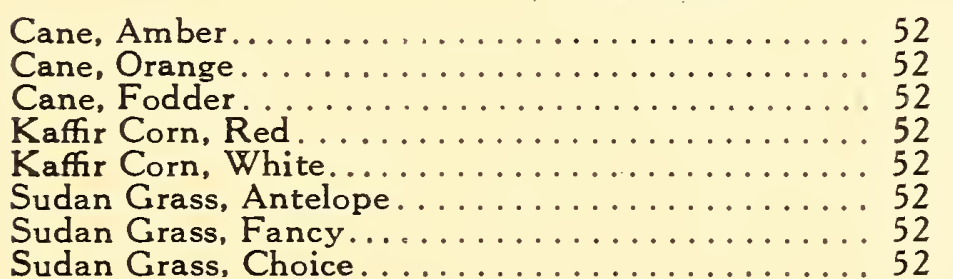

Market Price Market Price Market Price

Market Price Market Price

SEED CLEANERS

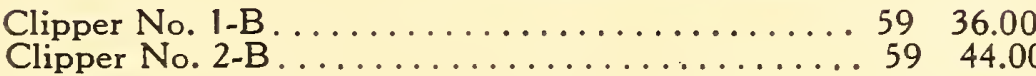
$59 \quad 36.00$

BROADCAST SEEDERS

Ideal, each

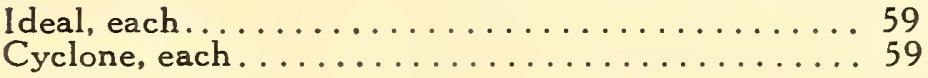
$59 \quad 1.00$ 3.00

\section{FIELD CORN}

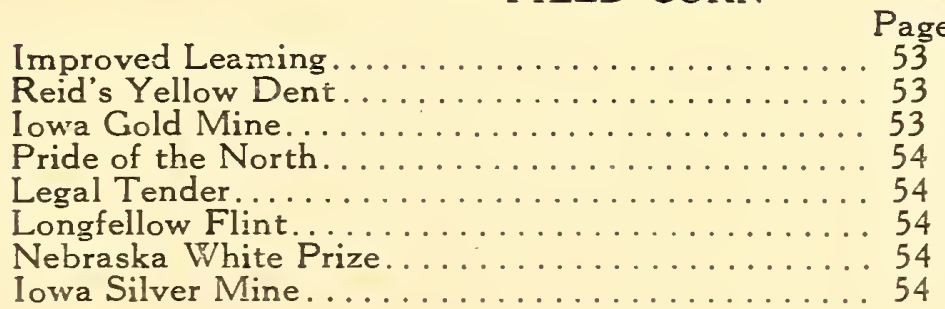

$\begin{array}{rrr}.05 & .45 & 4.00 \\ .05 & .45 & 4.00 \\ .05 & .45 & 4.00 \\ .10 & .40 & 3.00 \\ .10 & .40 & 3.00 \\ .15 & 1.25 & 11.00 \\ .12 & 1.00 & 10.00 \\ .10 & .90 & 9.00\end{array}$

\section{SWEET CLOVER}

White Biennial-Antelope............. 45 Platte.

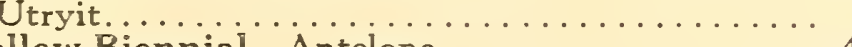

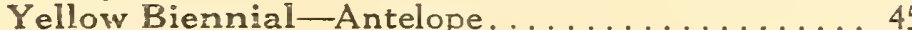

Flatte

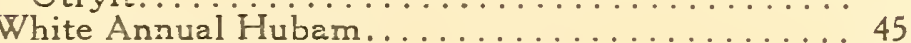

\section{KENTUCKY BLUE GRASS}

$\begin{array}{cccc}\text { Page } & 1 \text { lb. } & 2 \text { lbs. } & 5 \text { lbs } \\ \text { Antelope........ Inside Cover } & .60 & 1.10 & 2.75 \\ \text { Utryit......... Inside Cover } & .50 & .90 & 2.25 \\ \text { Fancy......... Inside Cover } & .45 & .80 & 2.00\end{array}$

$1 \mathrm{lb} .1 / 4 \mathrm{bu} .1 \mathrm{bu}$. $.10 \quad 90.3 .00$

$\begin{array}{lll}.25 & 2.25 & 18.50 \\ .23 & 2.00 & 18.00 \\ .20 & 1.75 & 16.00 \\ .20 & 1.75 & 16.00 \\ .18 & 1.60 & 15.50 \\ .16 & 1.50 & 15.00 \\ .80 & 7.50 & \end{array}$

\section{GRASS SEED}

Creeping Bent. 
HARDY PERENNIAL ROOTS AND PLANTS

\begin{tabular}{|c|}
\hline 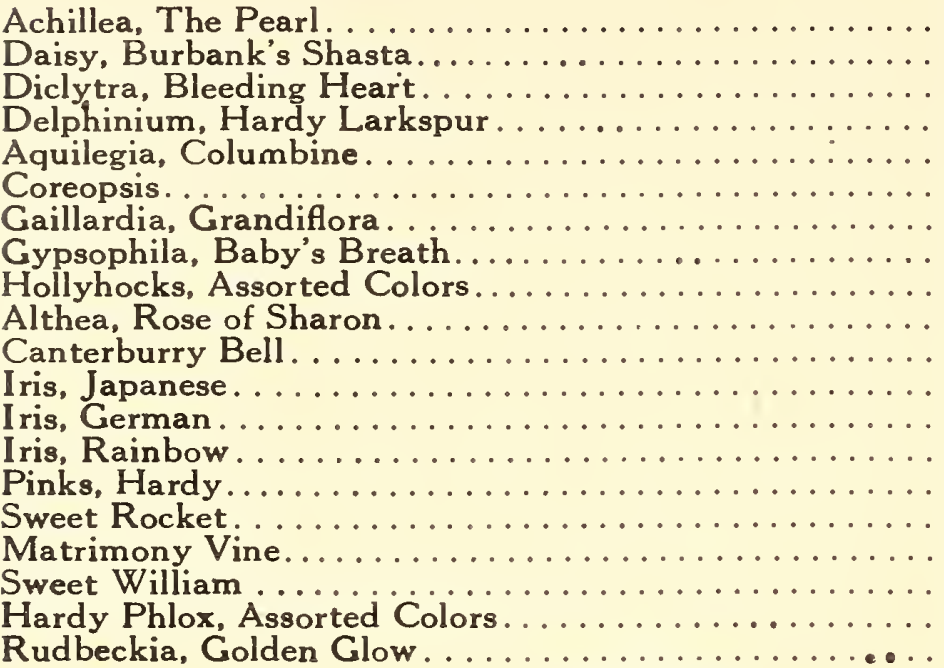 \\
\hline
\end{tabular}

Page
34
34
34
34
34
34
34
35
35
35
35
35
35
35
35
35
35
35
35
35

Each Doz

Doz
1.50

$.15-1.50$

5.00

2.00

2.50

1.50

1.50

2.00

1.50

1.50

1.50

1.50

1.00

1.50

1.50

1.50

1.50

1.50

2.00

PEONIES

Named Varieties as described on ............. Page Each $\begin{array}{r}\text { Doz. } \\ .40\end{array}$

Unnamed Varieties in Colors ................... $36 \quad .30 \quad 3.00$

CANNAS

Named Varieties as described on............... $37 \quad .15 \quad 1.50$

\section{CINNAMON VINE}

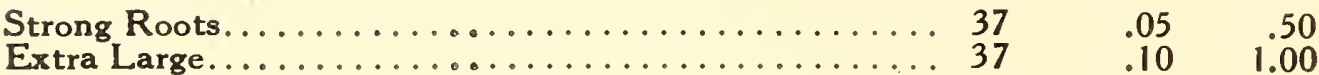

MADEIRA VINE

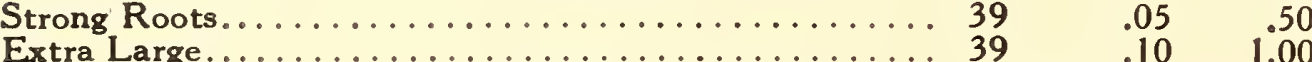

HARDY LILIES

Auratum, Gold Banded................... 37

Rubrum, Red Banded..................... 37

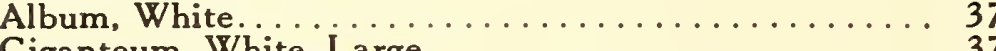

Giganteum, White, Large.

\section{GLADIOLUS}

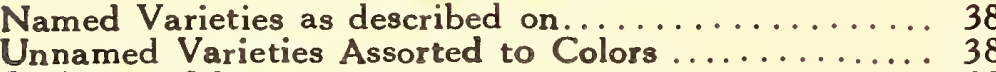

Perfection Mixture........................ 38

CALADIUM-Elephant Ears

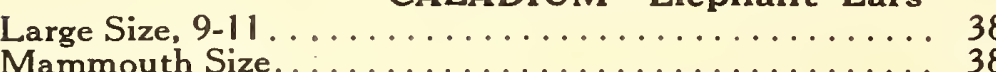

\section{TUBEROSES}

Excelsior Pear

DAHLIAS

$.35 \quad 3.50$

$\begin{array}{rr}.40 & 4.00 \\ .35 & 3.50\end{array}$

$.40 \quad 4.00$

$.10 \quad 1.00$

$\begin{array}{ll}.07 & .70 \\ .05 & .50\end{array}$

.35

Mexicanum

Assorted Colors

Named Varieties.

\section{PLANET JR IMPLEMENTS}

Each

No. 25 Combined Drill ............................. 26.00

No. 4 Combined Drill . . . . . . . . . . . . . . . . . . . . . . 21.50

No. 4 Drill Plain................................... 17.00

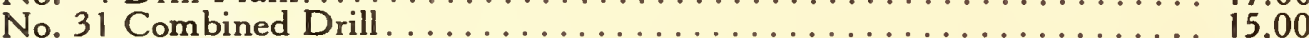

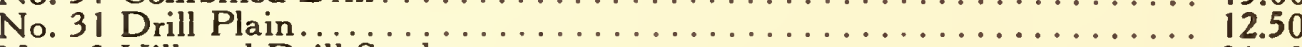

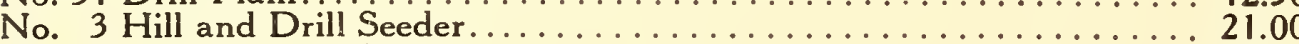

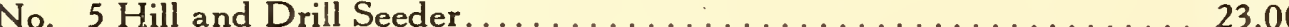

No. 1 Drill Seeder...................................... 15.00

No. 11 Double Wheel Hoe. . . . . . . . . . . . . . . . . . . . 16.75

No. 12 Double Wheel Hoe. . . . . . . . . . . . . . . . . . . 13.00

No. 13 Double Wheel Hoe. . . . . . . . . . . . . . . . . . . . . . . . . 9.25

No. 16 Single Wheel Hoe............................... 10.75

No. 17 Single Wheel Hoe....... 9.00

No. 18 Single Wheel Hoe . . . . . . . . . . . . . . . . . . . . . 7.00

No. 19 Single Wheel Hoe. . . . . . . . . . . . . . . . . . 7.00

No. 8 Horse Hoe............. 21.50

Complete Planet Jr. Catalogue on Application POJLTRY SUPPLIES

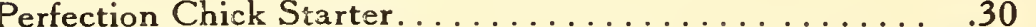

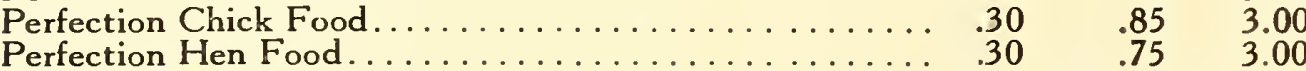

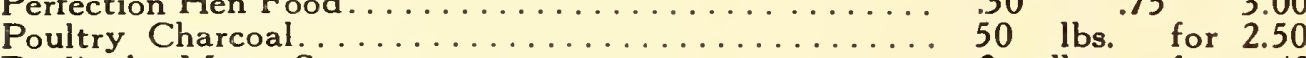

Darling's Meat Scraps................... 3 lbs for .40

Darlings' Meat Scraps....................6 $61 / 2$ lbs. for .80

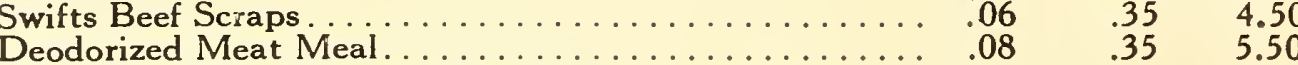

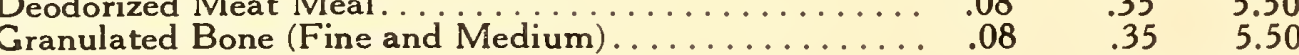

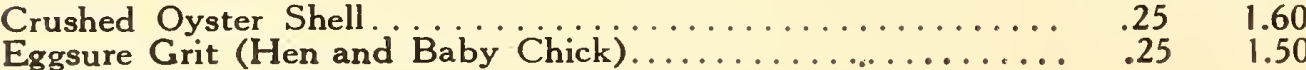

10 lbs. 100 lbs. 


\section{General and Descriptive List of Tested}

\section{VEGETABLE SEEDS}

Comprising All the Leading and Most Popular Varieties With Brief Cultura] Directions.

\section{ASPARAGUS}

\section{Spargel. Asperge.}

OUITURF.-Sow thinly in drills 1 inch deep 1 foot apart in April or May. Thin to \& inches, leaving only the strongest plants. Transplant when one or two years old in a thoroughly enriched soll, dug up to a depth of 18 inches. Set three rows 1 foot apart in a 5 -foot bed, plants 1 foot apart in the row. Never cut too closely, as the roots need some follage to continue their growth.

PAIMETrO. An exceedingly early wright green Asparagus of good size and splendid flavor. Very productive.

COIOSSAI OR ARGFITEUII. The famous French variety, large and productive.

COLUMBIAN MAMMOTE WEITE. A fine large white variety.

BARB'S MAMMOTH. The stalks are very large, cometimes nearly an inch in diameter, with few cales; the stalks retain their thickness completely up to the top and have close round heads. They are quick growing, tender and succulent.

\section{ASPARAGUS ROOTS}

For the private garden we strongly advise plantIng asparagus roots, saving thereby a year's time.

Plant our 2-year-old selected roots and a full crop can be cut the next year.

PAIMETTO. 2-yearold selected.

CoIossaI, 2-year-old selected.

COIUMBIAN. 2-yearold selected.

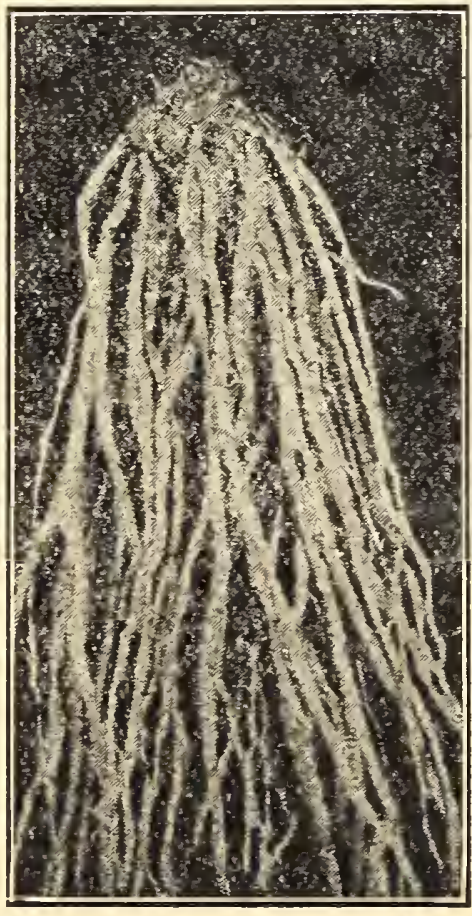

TWO-YEAR-OLD ASPARAGUS ROOTS.

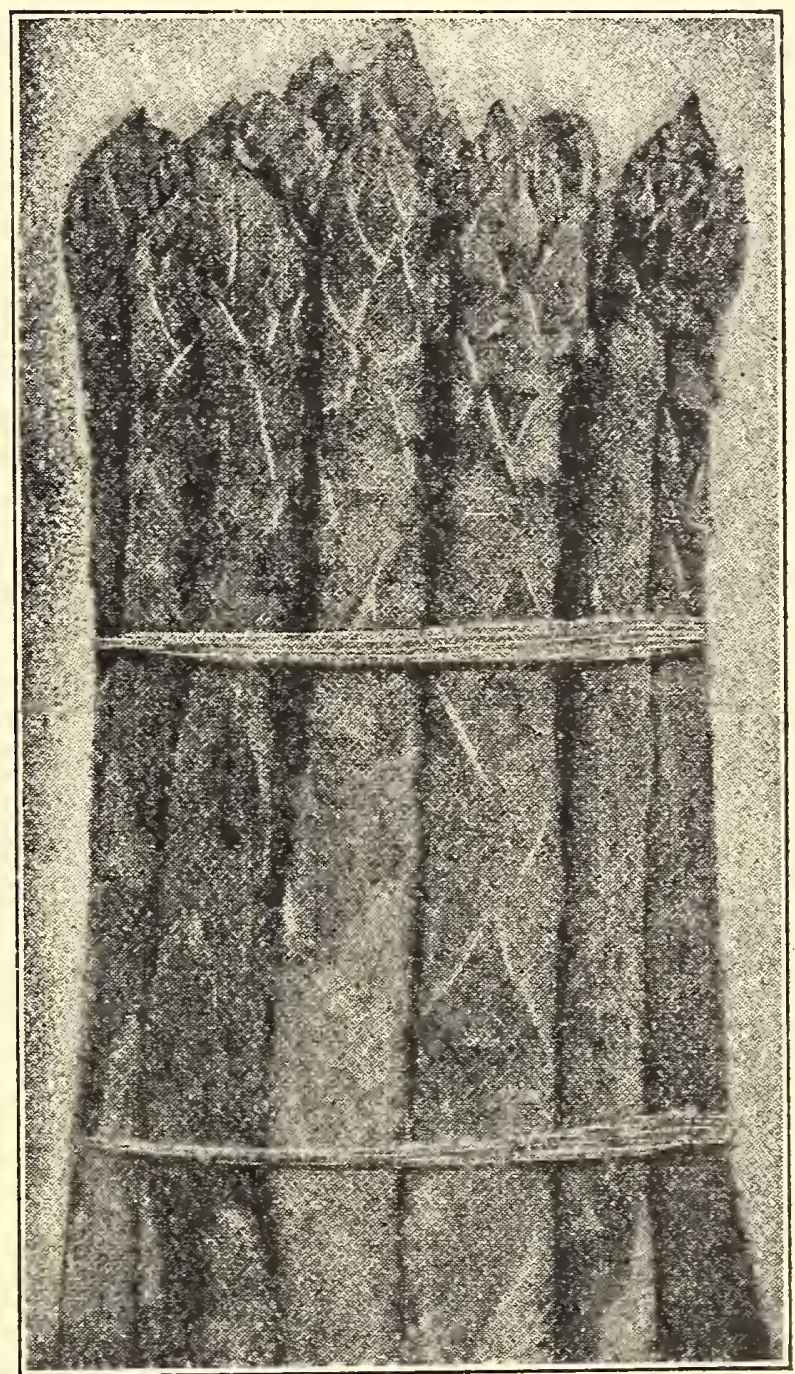

ASPARAGUS, PALMETTO.

\section{ARTICHOKE}

\section{Artichoke. Artichaut.}

The popular European vegetable, grown for the flower heads, which are cooked in the unripe state, similar to Asparagus.

CUITURE.- Sow in February or March in hotbed or boxes. When ground is ready transplant 2 feet apart in rows 3 to 4 feet apart.

IARGE GREEN GTOBE. Largest and best.

\section{BRUSSELS SPROUTS}

Rosen-Kohl. Chou de Bruxelles.

CUITURE.- Sow in March or April like Cauliflower and transplant in July 1 foot apart rows 1 1/2 feet apart. Highly esteemed for bolling during the late fall and winter months. The "sprouts" resemble miniature cabbage, growing closely on the stalk of the plant.

ducing compact heads of fine quality.

IMPROVID DWARE. A istandard variety. 


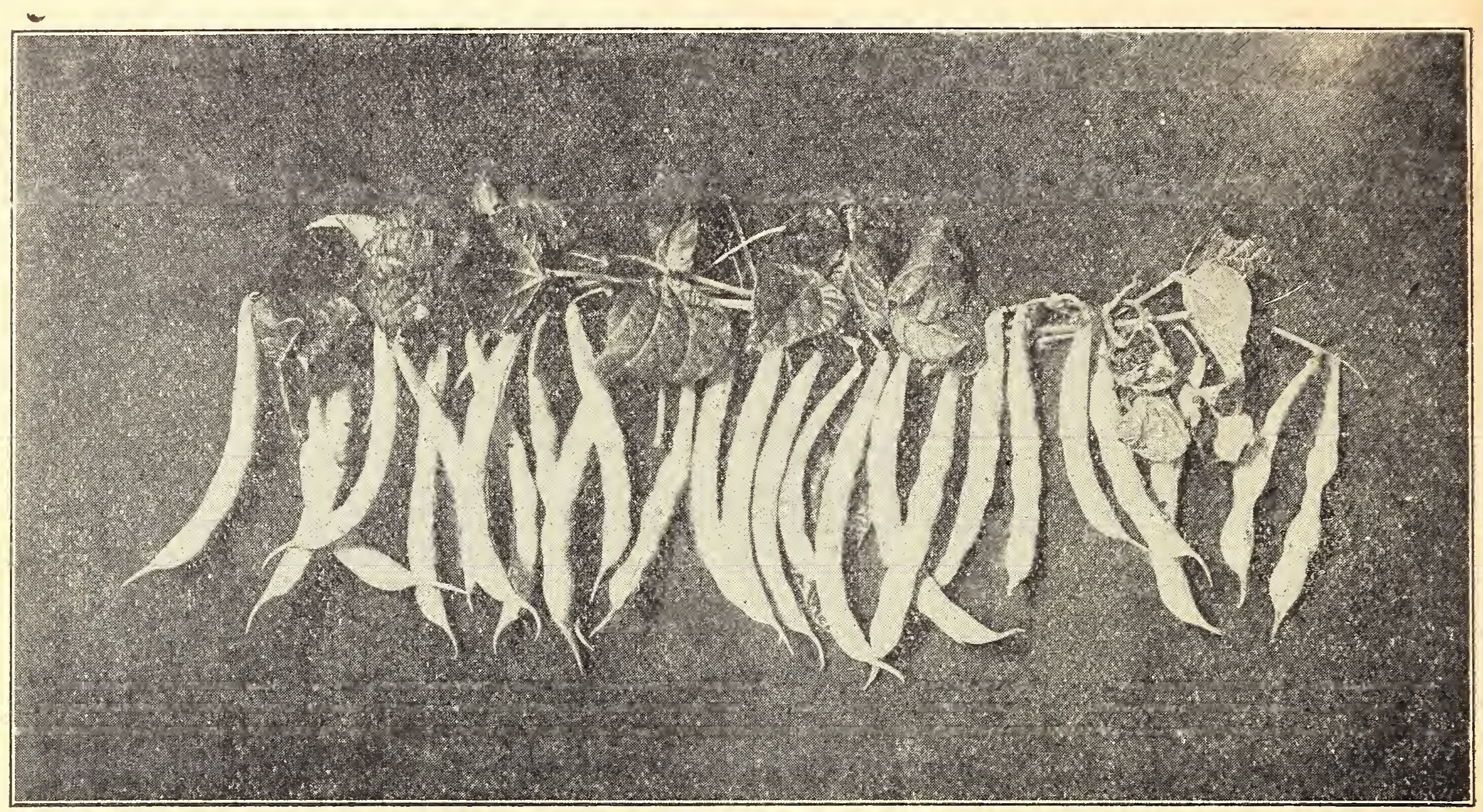

BEANS - DWARF, BUSH OR SNAP

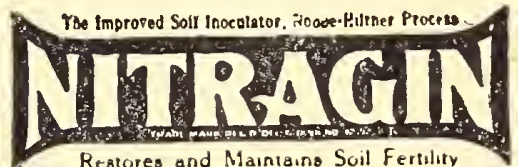

\section{GREEN PODDED VARIETIES}

CUITUEF.-Early in the spring, after the gro und is perfectly warm, the Beans should be sown in drills 2 inches deep and 18 inches apart, dropping the Beans 3 inches apart in the drills. Hoe well in dry weather and plant every two weeks for sucomion.

FUII MEASURE. Pods round and extremely long, many measuring five inches, and perfectly stringless. The quality is excellent, being very tender and remaining so even after pods mature.

STRINGIJSS GREET ROD. This variety is ready for use several days ahead of Valentine, is absolutely stringless, retains its tenderness long after maturity, and remains longer crisp and brittle after picking than any other variety. Tta earliness and unequaled productiveness make it positively the best green bean.

EARHY BOUNTIFUH. This is one of the best green podded beans, especially for the market gardener. It is as hardy and productive as Six Weeks and has stringless pods of unusua!ly good quality. The pods are borne early and are 5 to 6 inches long, broad, flat and meaty and almost lacking strings.

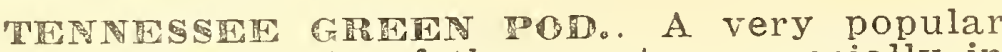
sort in some parts of the country, especially in the south. The plants are large spreading and prolific: the foliage dark green and crumpled. The pods are long-5 to $5 \frac{1 / 2}{2}$ inches-flat, irregular in shape, light green and of exceptionally fine flavor.

FORDHOO聚 HAVORITE. A round podded variety maturing a few days later than Stringless Green Pod. The plant grows 18 to 20 inches in height, bears an abundance of fleshy pods 5 to 6 inches in length and half an inch in diameter and entirely stringless. The seed, being white, may be used as shell beans in winter.

GIANT STRINGIESS VAIRNPINE. A mammoth podded selection from the original Stringless, not quite so early, but the pods are onethird larger. They are always absolutely stringless, round. full and fleshy, surpassing all others in crispness and flavor.

EARLY RED VALENTINE. A long variety of vigorous, upright growth and an excellent yielder. The pods are round, light green, tender and of fine quality.

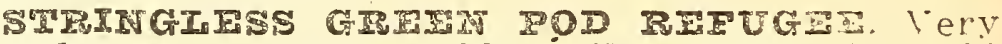
popular: enormous yielder. For more than 20 years the originator of this variety has been working to eliminate the string of the old Green Pod Refugee. In this new bean he has succeeded, and we are glad to be able to offer our customers this Stringless Refugee. Its habit of growth is practically the same as the old Thousand to One Refugee, but maturing its beans earlier. Vers productive; of true bush form: attains a height of eighteen inches. The handsome, round, green pods average about 5 inches long and are brittle. tender fleshy and perfectly stringless. Its quality is superfine; beautiful green color, entirely stringless, makes it superior to any other variety. Very popular with canners.

IONG YEITOW SIX WEEKS. Early, productive and of excellent quality: pods often eight inches long; a popular rariety.

TाTT: YAVY. Grown exclusively as a shell bean for winter use. 


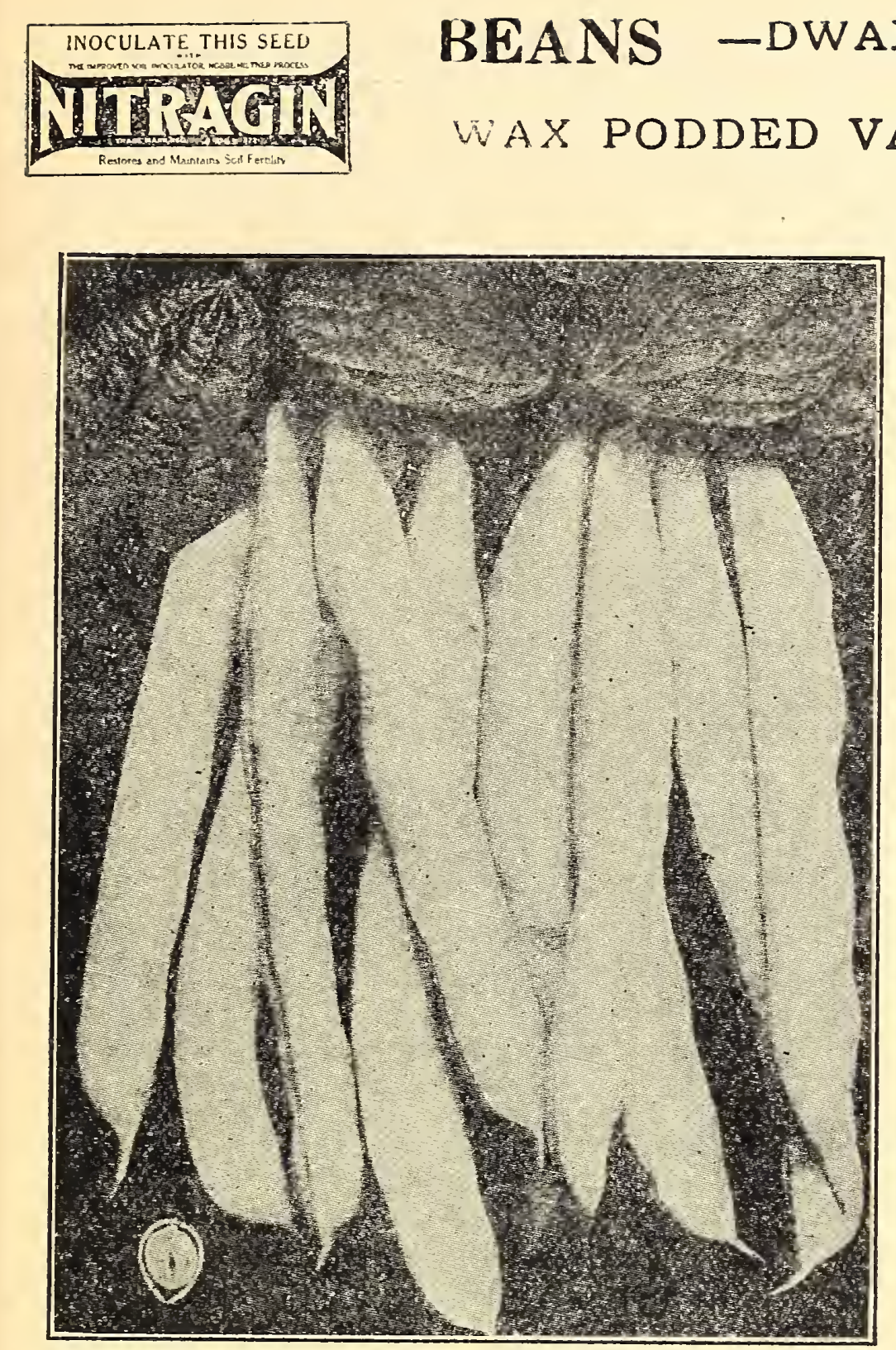

UA VIS' KIDNEY WAX.

DAVIS' KIDNEY WAX. The pods are long, straight, of a waxy white color, do not stain in canning, and are very brittle, crisp and tender The vines are vigorous and well nigh rustproof. It is positively the most productive wax bean in existence and remains fresh and brittle long after picking, making it an excellent shipper. It is also unequalled for baking.

WARDWELL'S KIDNEY TVAX. The large size, fine appearance and good quality. of the pods make this one of the most popular varieties of wax beans. The plant is upright in growth, bearing broad, flat pods of light waxy color and 5 to 6 inches in length.

ROUND POD KIDNEY WAX. The pods of this new variety are perfectly round, long and entirely stringless. It fully equals its parent, the well known Wardwell's Kidney Wax, in every respect. It is decidedly an acquisition.

PROLIFIC BLACK WAX. The most improved type of the Black Wax Bean, combining the qualities of earliness, productiveness and size of pod with excellent flavor and handsome appearance. Easily harvested, free from rust.

PENCII POD BIACE WAX. The best quality round pod early Wax Bean. It has a bushy growth, height 15 inches; is extremely productive. Pods are straight, round, six to seven inches long, thick, absolutely stringless, of fine flavor; color medium vellow. The seed is black. An all round high quality sort for the kitchen garden or the market gardener.

ROYAI PURPIE WAX. The best wax bean for the market gardener. The flat lemon-yellow pods are stringless and quite meaty. Very early, one of the earliest wax varieties, and an enorm. ous yielder. It is disease resistant, hardy and 9.1together a very dependable sort.
IMPROVED GOLDEN WAX. This is a vast mprovement on the old strain of Golden Wax. The new strain is so much hardier and less liable to blight or rust that it has become one of the most desirable of the wax podded varieties. Pods are $31 / 5$ to 4 inches long, flat, straight, meaty and of highest quality.

RUST PROOF GOLDEN WAX. The vines are vigorous, the foliage abundant and absolutely rust proof. It is early, very productive and as a market variety it is unsurpassed.

UNRIVALLED WAX. A new Wax Bean-Earls, prolific and lucious. This bean is early, hardy, very prolific, entirely stringless, and as good, in quality and productiveness as Burpee's Stringless Green Pod. Unrivalled Wax grows upright, bearing the beans well off the ground and is loaded with large, handsome pods. The pods arerage six inches in length. are light yellow in color, well filled and meaty; they are entirely stringless and of the most delicious flavor. It is the most prolific bush bean we know of, and this combined with its large, handsome, delicious, stringless pods, makes it most valuable for any and ever. purpose.

\section{BUSH LIMA BEANS}

NEW WONDER BUSF IIMA. Earlier and more prolific than Burpee's. The plants are large. compact and very prolific. The pods are green, uniform and large, and excellent quality.

DREgR'S BUSF IIMA. Is the bush form of Dreer's Pole Lima. It is very early in maturing and productive.

BURPEF'S BUSH IIMA. Grows elghteen to twenty inches high, and is very productive.

FENDERSON'S BUSF IIMA. Smallest of the dwarf Limas and at least a week the earliest.

\section{POLE OR RUNNING BEANS}

\section{Stangenbohne. Haricots a rames.}

CUITURE. These are more tender and require more care in culture than the bush bean's and should be planted two weeks later. Plant in hills from three to four feet apart; plant five or sis. beans in a hill, leaving a space in the center for the pole.

DUTCF CASE RIIFE. A standard sort.

KENTUCKY WONDER. Vines vigorous climbing well and very productive, bearing its pods in large clusters; pods green, very long, often reaching nine or ten inches.

IAZY WIFE. One of the best for snaps of the later green podded pole beans.

SCARIFT RUNAIE. Chlefly grown for 1 ts brilliant scarlet flowers.

FING OF THF GARDET ITMA. Vines very vigorous and productive. Pods five to six inches long, filled with four or five immense white beans of the finest quality. On account of its large pods it is a favorite with market gardeners. It will come into bearing sooner and will make larger pods if not more than iwo vines are left to grow on a pole. Seed very large, ovold, flat, with slight greenish tinge.

CUT SEOET, OR CORN EIII. An old variety, very popular in the central and southern states for planting among corn. It will give a good crop without the use of poles.

EARLY JERSEY LIMA. This variety is ready for use a few days earlier than King of the Garden. Pods contain three or four large beans each.

WHITE CREASFBACK. Early, round green pods, tender and prolific. This green podded, white seeded creaseback variety is valuable for its extreme earliness, producing pods in 45 days in clusters of from four to twelve. The pods are about 6 inches long, perfectly round and stringless. Dry, white beans are excellent for winter. 


\section{GARDEN BEETS}

CUITURE.-Sow as early in the spring as the ground cen be worked (one ounce will sow 6u feet of drill, ive pounds will sow an acre) in drills 1 foot to 15 inches apart; and when the seed is well up thin them out from 4 to 6 inches apart. Sow overy two weeks for a succession, up to the 1st of July.

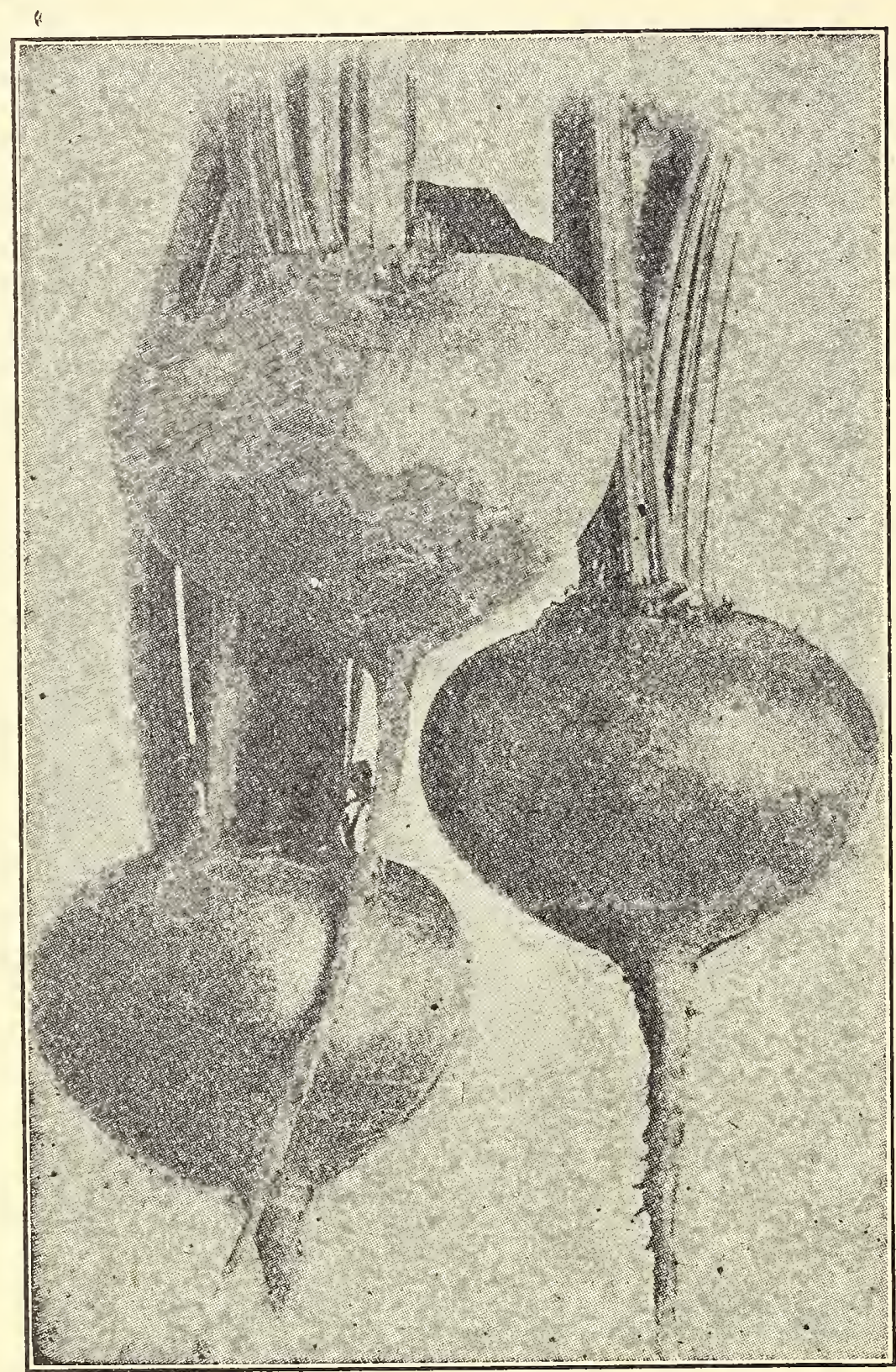

CROSBY'S EGYPTIAN. fault with most turnip beets is the occasional appearance of white rings, but by careful selection this has been overcome, and this will be found one of the deepest red beets. Valuable for market gardeners.

EXTMA IARIY EGYPTIAN. The best variety for forcing and unexcelled for first early crop out of doors. The roots are of a deep crimson color, rounded on top and flattened beneath. The tops are unusually small.

EARIY BIOOD TURITI. A standard second early variety which attains a good size ind is excellent for late keeping. The old istandby.

FDMANDS BIOOD TURNIP. The best bet for late keeping. Attains a good size, grows smooth and uniform roots, tops are small. Flesh deep red zoned with lighter shade. We recommend this for a main crop beet.

IONG SMOOTE BIOOD. The standard lone sort.

SWISS CEARD, OB SPINACE BLयL. This VAriety does not produce an edible root like the resular garden beet, but is highly esteemed for the broad white leaf stalks and midribs which are cooked and served in the same manner as asparagus, making a delicious vegetable. The leaves are also cooked like spinach and considered equally as palatable. Two separate dishes may thus be grown from one plant at the same time.

\section{CHIVES}

Chives are perfectly hardy little perennial mem. bers of the onion tribe and are grown exclusively for their tops, which are used wherever the flavor of onion is desired. Planted in small clumps in any common garden soil, they will grow readily.

\section{CHERVIL}

CROSBY'S IGYPTIAN. One of the best for early planting out doors. It is a most excellent sort, becoming fit for use sooner than any other variety. An improved strain of the Early Egyptiar. being much thicker, smoother and of better color ad quality. We recommend this variety as an extra early beet for bunching.

ECIIPSE. An extra early beet of smooth and uniform growth, with very small collar and tap root. Color an intense crimson, with lighter zones. Exceptionally crisp, sweet and tender. Stands up exceptionally well after pulling, hence is a splendid market beet.

DETROII DARE RED TURIIP. A grand beet for bunching for market; tops are exceptionally small and uniformly upright; roots are perfect turnip shape with small tap roots. The principal
By many this is preferred to parsley for garnishing, and its aromatic leaves are much used for seasoning and in salads. Sow early in the spring in rich, well prepared sand soil.

\section{CHICORY}

IARGE ROOTED, OR COFFrE. Sown in drills, the roots become well developed. When they are dried, roasted or ground, they become the chicory of commerce, and are used in adulterating coffee.

WITIOOF. Witloof is used principally as a winter salad. The seed should be sown in the open ground not later than June. The plants form long, parsnip-shaped roots which are lifted in the fall, trimmed of leaves. and stored in soll in a cool place until wanted for forcing. The roots can be forced in any warm cellar or room, requiring about one month to make edible sprouts. 


\section{MANGELS OR STOCK BEETS}

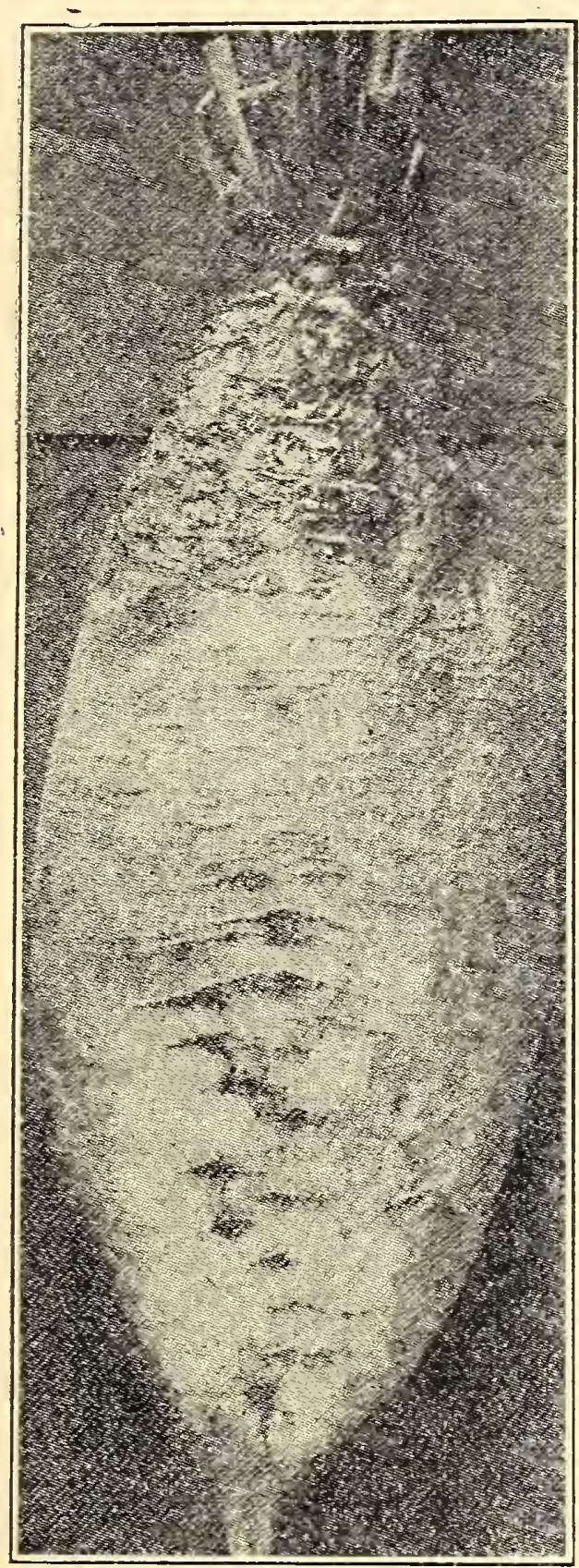

HALF SUGAR MANGEL.

Root crops are highly valuable and worthy of more general cultivation in the United States. The feeding value of roots is directly proportional to the dry matter content. This dry matter, pound for pound, is equal to any grain; when fed to cattle is more eagerly eaten and more digestible. This dry matter runs from 10 to 14 per cent of total weight. Thus a low yield of 20 tons would give over tons of dry matter equal to 65 oushels of corn. A supplementary ration of cereal is good.

Successful cultivation depends largely upon a well prepared seea bed. ploughed deep and well pulverized. Sow 6 pounds of seed per acre. On carefully prepared land yields of 40 and 50 tons per acre have been taken not uncommonly. The Mangel is a dependable cropper, ripening after harvest, is ready to feed January 15 th. Mangel diet gives one-third more milk than potatoes when fed to milch cows.

DANISE SIUDSTRUP. The Danish government encourages the growing of root crops by offering certificates of merit to growers who select and produce sorts which are of distinctive value. Sludstrup is considered the best of all mangels, having been awarded first-class certificate. In color it is reddish-yellow and of a distinct type. It contains the largest per cent of nutriment found in any sort. It is very hardy, grows well above ground and is easily pulled.

GIAN'T HALF-SUGAR ROSE. The roots of this new variety are valuable for their very high dry matter content, being, pound for pound, nearly equal to the best strains of sugar beets. Besides which they are mole succulent in feeding than the latter. Moreover, as they grow out of the ground, they are much more easily harvested than are sugar beets.

GIANT FCKENDORF MANGㅍ. This is the most popular German variety of mangel. In Germany is more largely planted than any other sort. Selected especially for a square, chunky type, it is valuable not only for its high percentage of dry matter, but also for Its phenomenal yields. Roots weigh as high as fifteen and twenty pounds apiece. They grow cylindrical in shape and are yellow. As the greatest portion of the root grows above the surface of the soil, they are easily harvested, and their chunkiness prevents their breaking in handling. This is one of our best varieties.

MAMMOTF LOKG RED. This is the most productive mange] variety, yielding enormously. Crops as high as forty to sixty tons to the acre have been produced, and a single root often weighs twenty to thirty pounds. It grows well above the ground, and is easily pulled; very hardy and a good yielder.

GOLDEN TANKARD. This is the best known yellow mangel. It is a very distinct variety and contains probably the largest per cent of dry matter of any of the mangels. It is cylindrical in shape and easily pulled; very hardy. and a good yielder.

MAMMOTH IONG TrIIOW. Similar to Irong Red except in color.

\section{SUGAR BEETS}

The growing of Sugar Beets in the United states has become one of our most important industries. Our seed is from the best growers, who select all their beets by laboratory tests for hion sugar content. Our seeds will raise beets witis a much higher percentage of sugar than seed Grdinarily offered. They are also superior fnr stock feeding, as they are very high in dry matter content.

VILMORIN'S IMPROVID. An improvedFrench variety, exceedingly rich in sugar. Under average conditions it has yielded 14 tons of roots to the acre, containing about 16 per cent of sugar.

KIFIN-WANZLFBFN. This kind is cultivated on a larger scale than any other sugar beet. Th* root is conical. straight and even, quite large at the head and rapidly tapering. It is easy to dig and is a heavy yielder.

IANE'S IMPERIAI. Heavy yielder, flesh snow white.

\section{CORN SALAD}

CUITURE,-Sow early in the fall or first of the spring, in shallow drills, about twelve inches apart. Cover lightly and if very dry occasionally water. To protect through the winter cover with straw or light evergreen brush.

IARGE IFAVFD. The best variety cultivated

\section{CRESS}

CUITURE.-Sow peppergrass early in the spring in shallow drills, and every two or three weeks for a succession; cut often, as it will continue to grow. The watercress must be sown on the margin of a stream or running water or in $a$ very moist location.

CURIFD, OR PFPPRGRASS. Common and well known.

TRUE WATERCRISS, Leaves tender and high. ly flavored. 


\title{
CABBAGE
}

\author{
Kopfkohl. Choux Pommes.
}

CUITURE-To secure early cabbages sow seed in fall in boxes and winter the young plants in cold frames, or it may be sown in February or March in hotbeds. The latter plan is generally adopted in this neighborhood. The February sown plants, when large enough, should be transplanted into cold frames, and as early as the ground is in fit condition they should be planted into the garden in rows about two feet apart and about eiristeen inches apart in the row. The late varieties should be sown about the 1st of May and set out in the garden in July. As these grow larger than the early varieties, they should be planted in rows about three feet apart and about two feet apart in the row.

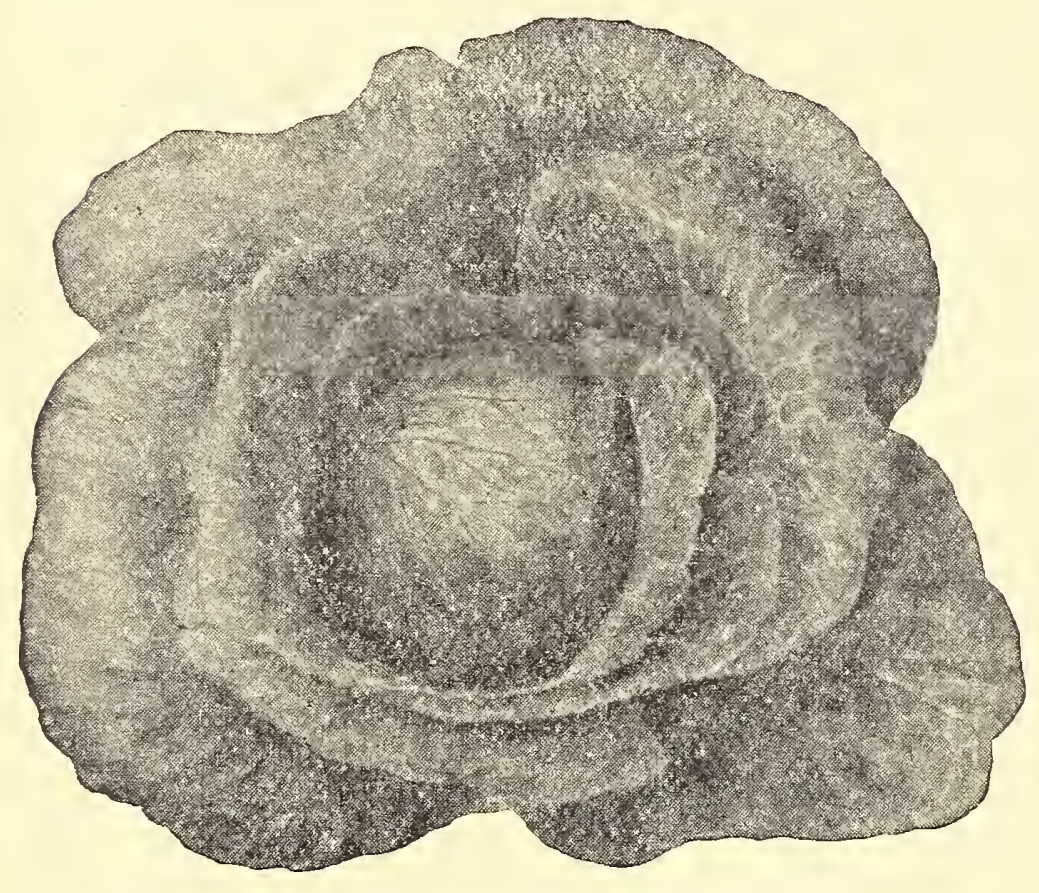

COPENHAGEN MARKET.

COPENGAGEN IMARTET, OR DANISE SUMMTR BAIIIEAD. This splendid new variety, first introduced by us in 1912, is an extra early round-headed sort, maturing with the Wakefields and is of much larger size. Where grown alongside of all other early sorts it was ready for cutting a week sooner than any of them. Each plant formed a perfect, tightly-folded head, averaging five to eight pounds in weight and about eight inches in diameter each way. The compact growth of the plant the solidity of the head. its excellent flavor and extreme earliness-all combine to make Copenhagen Market one of the most meritorious cabbages that have come to our notice in a decade. We pronounce it, without reserve, the finest and earliest round-headed sort in cultivation today.

FARIY JFRSEY WATEFIFID SEIFCTED. This is positively the best first early cabbage in existence, comblning a uniformity of earliness and of crop most unusual in first early varieties It forms fine, solid heads of good size and the best quality, conical in shape, with very few outslde leaves, admitting of close planting. Its extreme earliness makes it a sure money maker for the gardener who plants it for the early markets. The purity of our strain is unsurpassed.

PREMIUM IATE DRUMIFAD. We recom. mend this sort to market gardeneris and growers for shipping purposes. In good, rich soil and with a favorable season, the heads will grow to an enormous size. Very compact and solid and of excellent flavor.

FENDFRSON'S FARII SUMMER. This varlety is deservedly popular with market gardeners. It forms large, solid, round, compact heads of excellent quality.

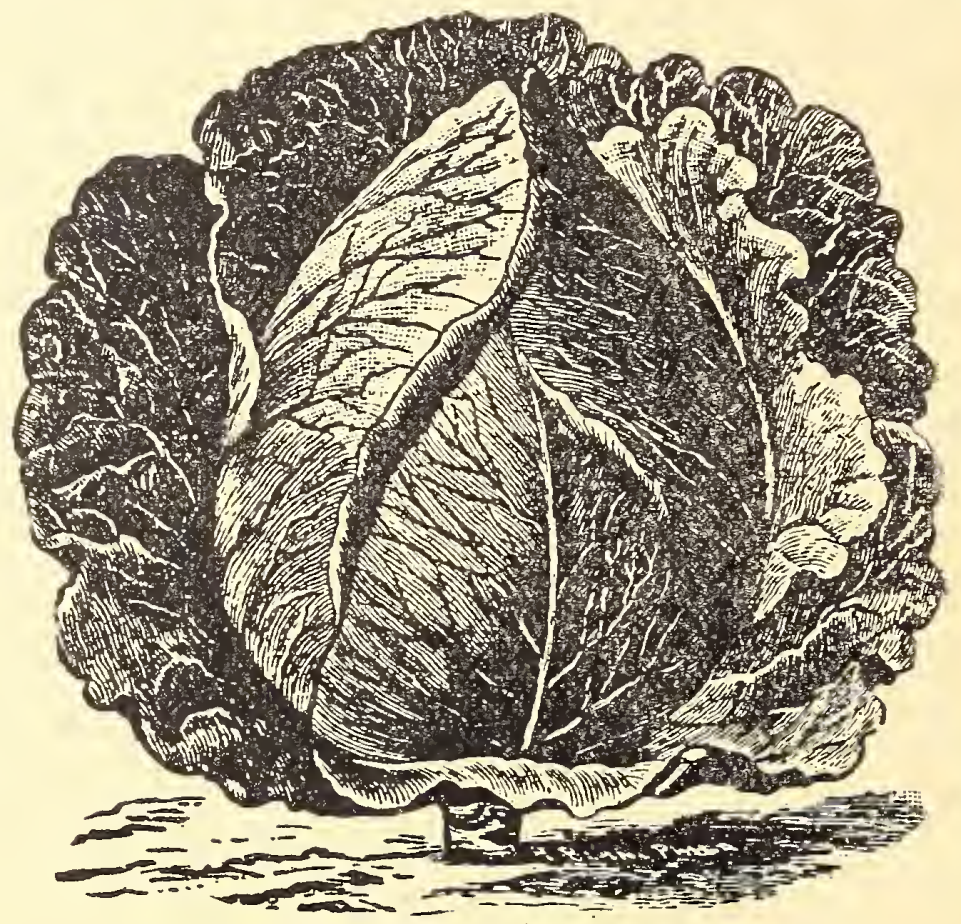

EARLY JERSEY WAKEFIELD.

TARGE JFRSTY OR CEARIFSTOIT WAFI FIFID. While but a few days later, this sort forms heads nearly double the size of the Early Wakefield.

FARIY AIIHEAD (BURPFF'S). For uniformity, reliability of heading, size, quality and earliness, this variety is unequalled. Its fow outer leaves allow close planting, Increasing its profitableness.

HFNDERSON'S SUCCFSEION. One of the finest second early cabbages yet introduced. It is about one week later than the Early Summer, but is double the size and is so finely bred that, in a field of ten acres, every head was a perfect specimen, fit for exhibition purposes.

AII SFASONS. This variety is certainly one of the very best for all the year around, forming a solid and compact head of very fine quality.

SURFEFAD. Very reliable cabbage, large, round, flattened heads of the Flat Dutch type. A good keeper and shipper, and has become very popular.

PREMIUM IATP FIAT DUTCH. N. S. Co.' Selected stocie. This is a sure heading strain of the Late Flat Dutch. Its large, solid heads, uniform cropping and splendid keeping qualities, recommend it particularly to the market gardener for late or main crop use Our stock of this variety has been especially raised for us from carefully selected heads, and is unsur. passed.

ST. LOUIS IATP MARKFT. This is a large, late strain of market gardener's cabbage. The heads are of large size, hard and firm, with but few outside leaves; stems short, foliage compact and of a beautiful green color. It is a very desirable variety for a late crop on account of its solidity and because it is an excellent winter keeper. It also stands a considerable time without bursting. The hard, thick, flat heads are remarkably uniform in color, as well as in shape and size. 


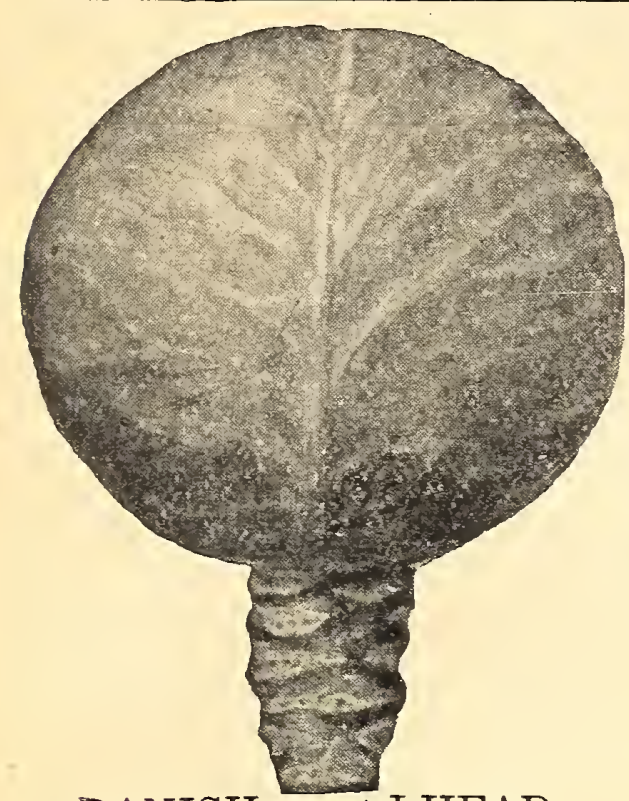

DANISH BALLHEAD.

PE-TSAI OR CHINGSF CABBAGF was introduced into this country by the Chinese of the Pacific Coast. Pe-Tsai may be grown more closely in small gardens, its leaves are more tender, and its uises wider than most salad vegetables. The Pe-Tsai belongs to the cabbage family, and produces quickly from seed sown in the open ground very attractive heads somewhat resembling a well-grown Cos Lettuce. The best results have been obtained from seed sown about August first, and it is optional with the planter as to whether plants should be started in the frames or the seed simply sown where plants are to remain, and the plants thinned out to

\section{CABBAGE}

DANISH BALLHEAD OR HOLLANDER. Because of its "great solidity" of head and its unequaled keeping an dshipping qualities, Danish Ballhead has supplanted nearly all other varieties for Danish seed of this variety over that grown in other countries and localities. The Ballhead we offer is the tall-stemmed strain, be distinguished from the short-stemmed "Hollander" or Dwarf Amager, the Danish grow nstrain of the Hollander. The heads are of an excellent market size-not too large. They are very hard, almost round, fine grained, and will weigh one-fourth more than other varieties of equal size.

stand about fifteen inches apart in the row, as the heads develop rapidly and grow to a large size.

\section{RED CABBAGE}

DAIISE RED STONgERA. A new, solid, fine ribbed, dark red cabbage, similar in shape to the red cabbages. Pkt., $5 \mathrm{c} ; 0 \mathrm{z} ., 35 \mathrm{c} ; 1 / 4 \mathrm{lb} ., \$ 1.25$.

MAMMOTH ROCK RED. This is the standard red cabbage. Pkt., $5 \mathrm{c}$; oz, $35 \mathrm{c} ; 1 / 41 \mathrm{~b} ., \$ 1.25$.

\section{SAVOY CABBAGE \\ Wirsingkohl. Chor de Savole.}

AMERICAN DRUMERAD SAVOT. This is a fine American-grown strain of beautifully crumpled and wrinkled Savoy cabbage, being far superior in every way to the imported Savoy seed a usually sown. The heads are large, solid and compact, and its fine appearance, coupled with the delicious flavor and tenderness, never fail to find ready sale.

\section{CARROT \\ Moohre. Carotte.}

CUITURE.-For successful cultivation soll $\mathbf{s}$ hould be light (sandy soll is the best) and deeply tilled. For an early crop the seed should be sown as early as the ground can be properly worked. For late crops it may be sown until about the middle of June.

FARTY CHANTEMAY. Has no equal as a bunching carrot. The roots are uniformly smooth, regular and perfect in shape. The flesh is of a beautiful deep orange, fine in texture, solid, but tender, and very sweet.

GUERANDE OR OXERARI. A variety with short, thick roots, the diameter often exceeding the length. Color bright orange, sweet and fine grained, good for table or stock.

DANVERS. There is no variety grown which will produce as much to the acre, with a minimum length of root, as this one. Under proper conditions of the soll and cultivation, it may reasonably be expected to produce, which it has done, 25 to 30 tons pe: acre. It is of medium length and heavy at the neck, but pointed and quite smooth, color a rich orange.

FARTY SCARIET HORN STUMP-ROOTED. A fine variety of medium size; color scarlet; fine flavor.

IMPROVED IONG ORANGE. A well known standard sort, roots long, thicliest near the crown, tapering regularly to a point; color deep orange; suitable for the table and main field crop.

GIANT WHITP BEIGIAN. For Feeding.

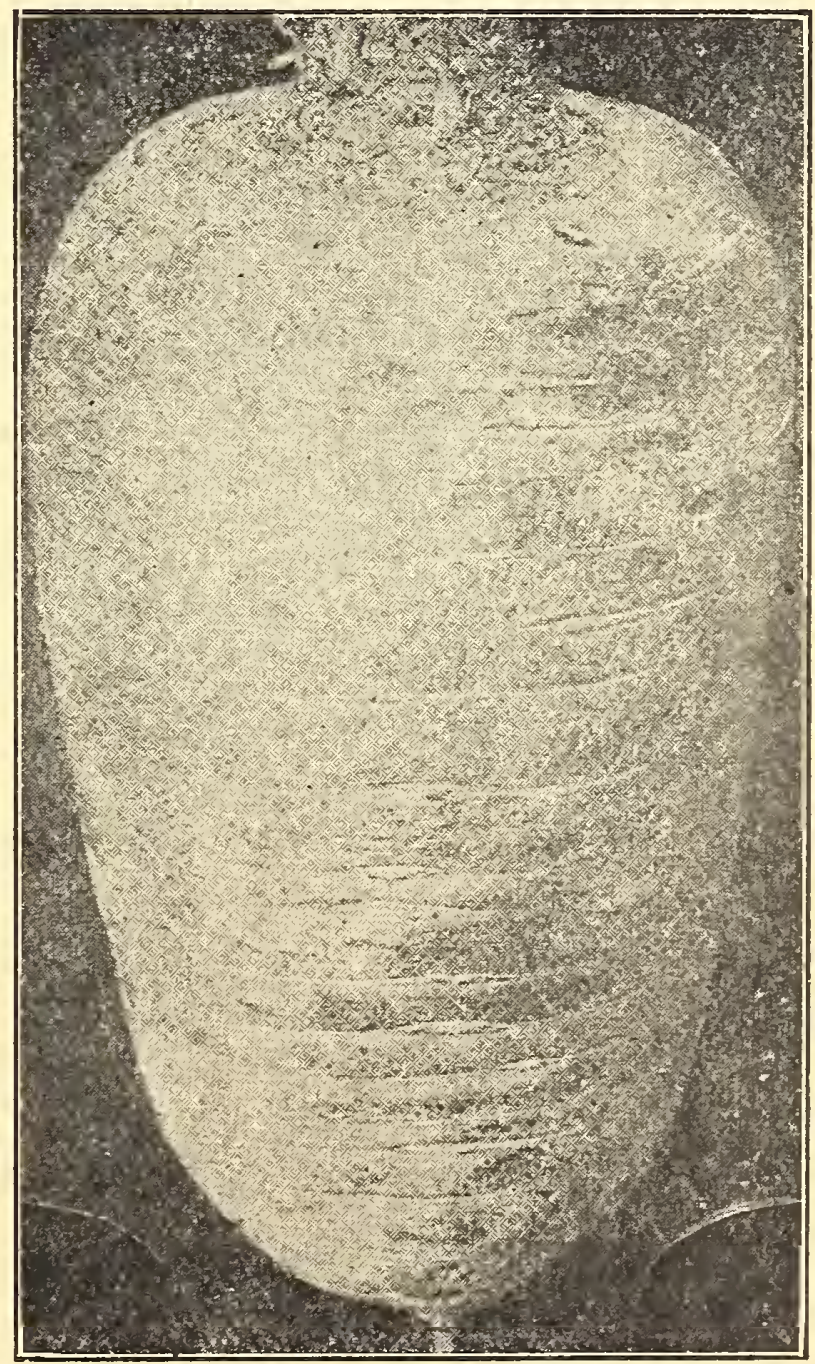

GIANT YEIIOW BELGIAN. For Feeding. 


\section{CAULIFLOWER}

Blumenzoh. Chou-now.

Success with this cholce vegetable depends very largely upon the rapld growth of the plant rom the time the seed has germinated until it is established in its permanent location. Make the oil as fine as possible for every transplanting, and do not allow the young plants to become checked at any time for want of water. For spring and early summer use sow in January or February in hot bed, and transplant to cold frame when sufficiently large, and to the garden as soon as ground is warm enough. For lato autumn crops sow in the early part of June, and transplant in July. In dry weather water Preely and as they advance in growth hoe deep and draw earth to the stem. When heading tle the outside leaves loosely over the heads to protect from the sun.

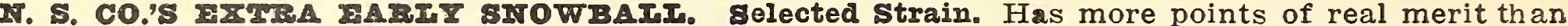
ny other caulifiower in cultivation. Extreme earliness, unusual hardiness, compact growing habit and an almost certainty to head, give it the preference over all other varieties. The heads are of large size, deliciously fiavored, of the finest texture and of the purest snow-white color; in form they are beautifully rounded, uniformly large, smooth and symmetrical. Its compact growth makes it unequaled for hothouse or cold frame culture; its very superior quality has made it the leading favorite for late crop out of doors. Our seed we import direct from our grower in Denmark. where climate, soll and season exactly fill the requirements for perfect maturing of seed as well as for perfect development of plant.

NIBRASRA IIARIRT. Every market gardener ought ro use some of this cauliflower, as this strain will head where others fall, and whether we have a dry or a wet season this cauliflower will always produce solid and pure white head.

FXTRA FARIY DWARF ERTURT. An excellent variety, producing magnificent heads of the finest quality. A reliable cropper which we recommend highly to market gardeners.

EXTRA FARIY PARIS. Head rather large.

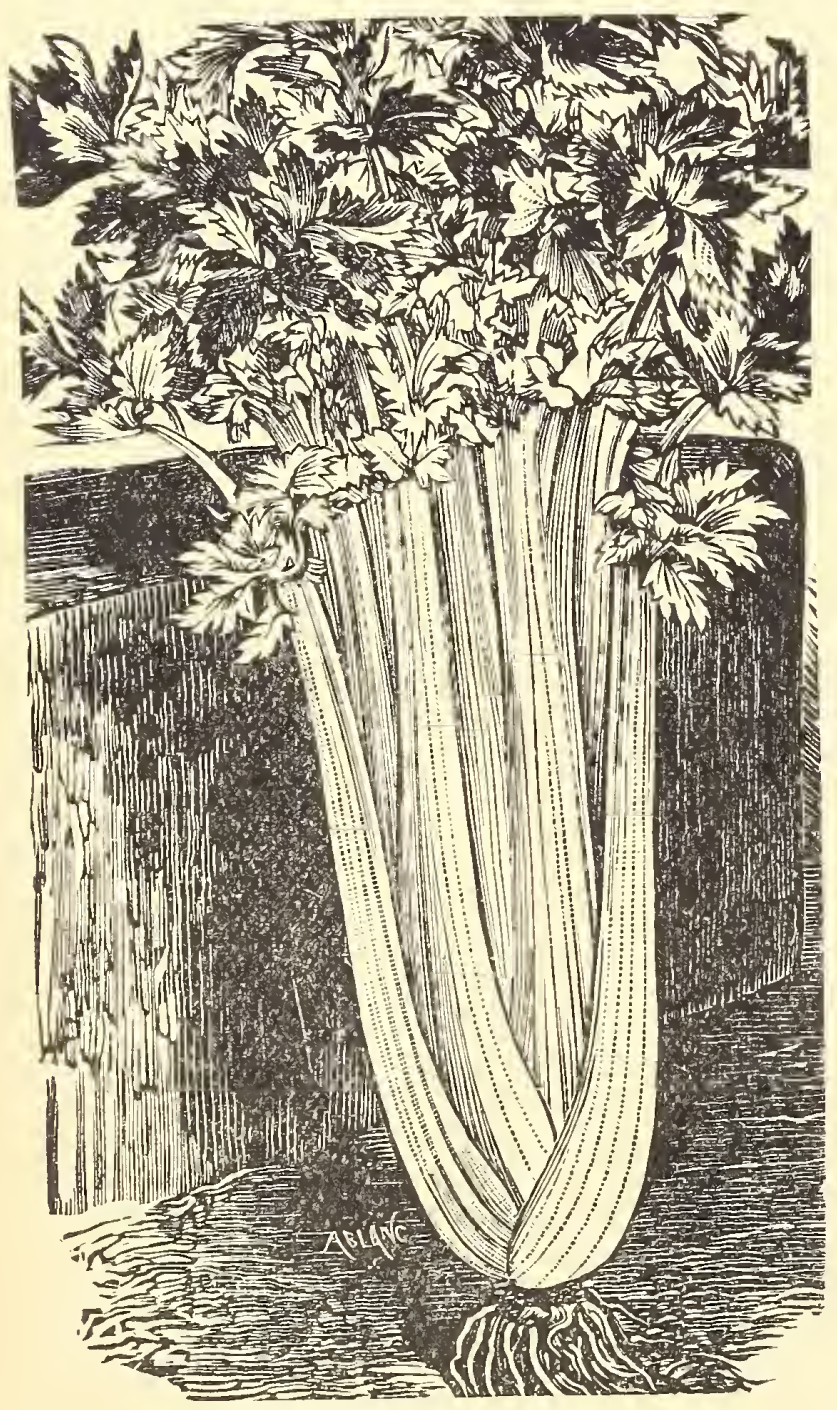

IF'H TTF PLUMr

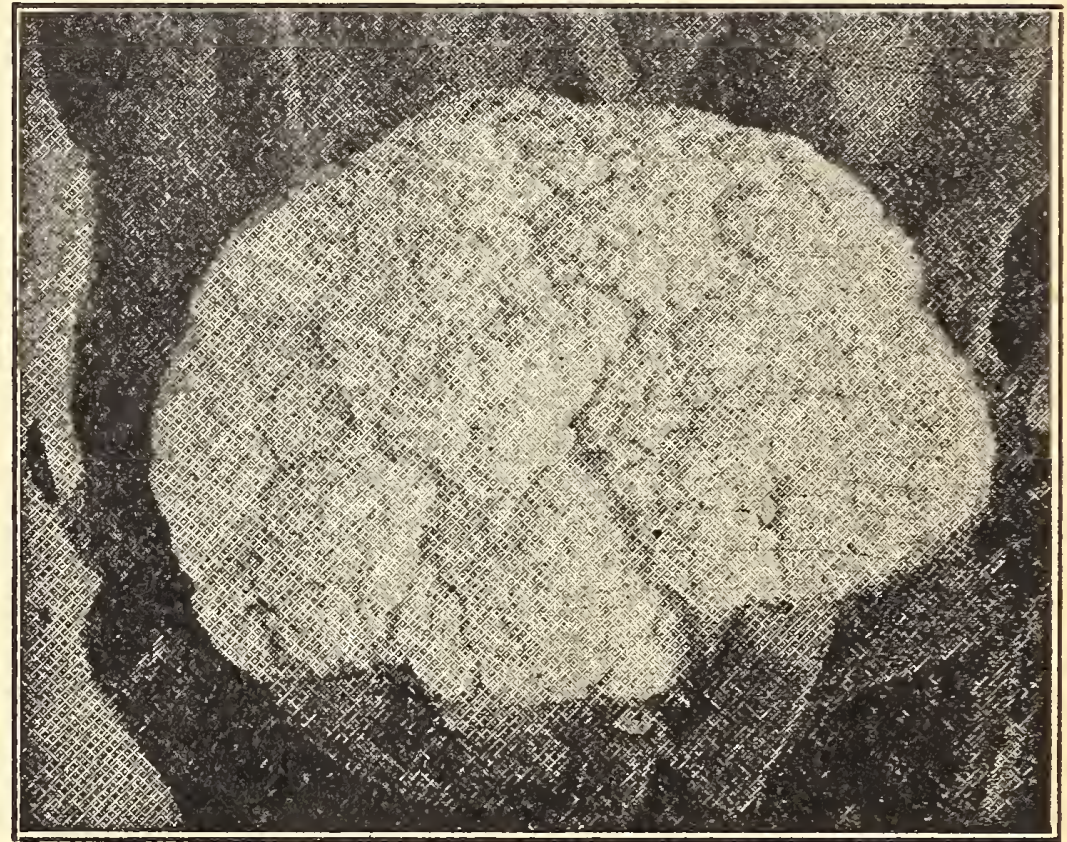

N. S. CO.'S EXTRA EARLY SNOWBALL.

\section{CELERY}

sellerie. Celert.

CUITURE.-Sow in April and May and rake seeds in light$y$; water and shade from strong sun. Prepare trenches from wo to four feet apart, a foot wide and a foot deep; dig into the bottom plenty of well rotted manure and set the plants when they are three or four inches high, six to eight inches part in each trench. Keep shaded until started and gradually warth them up as they grow.

WIIII PUUIME. Unlike all other varieties this one does not require to be earthed up, but if only loosely tied or a few landsful of earth brought closely around the base of the paves to keep them close together, all the inner leaves or thin stalks will turn white and crisp.

GOLDEN SELF BLANCHING. The best celery for early use. Our seed is a specially selected strain, produced by a celery seed ispecialist.

GINT PASCAL. The standard variety to grow for fall and early winter use, either in the home garden or for market. The plants are stocky, with thick, broad heavily ribbed leaf-stalks. The color is a rich green until blanched, when it changes to a yellowish white. Has a rich nutty flavor.

DWAR GOLDEN HEART. A popular variety for winter use. Solid, shapely stocks, surrounding a large solid heart that blanches to a beautiful yellow after storing. A fine keeping sort.

\section{CELERIAC-Turnip Rooted Celery}

GIANT PRAGUE. This is unquestionably the largest and best Celeriac in existence, The roots are very large, almost globe shaped, smooth, with only a few roots at the bottom. Flavor is excellent. 


\section{SWEET CORN}

CUrTURI.-Plant in hills three feet apart and leave four plants to the hill. Plant at intervals of ten days from early spring to middle of summer.

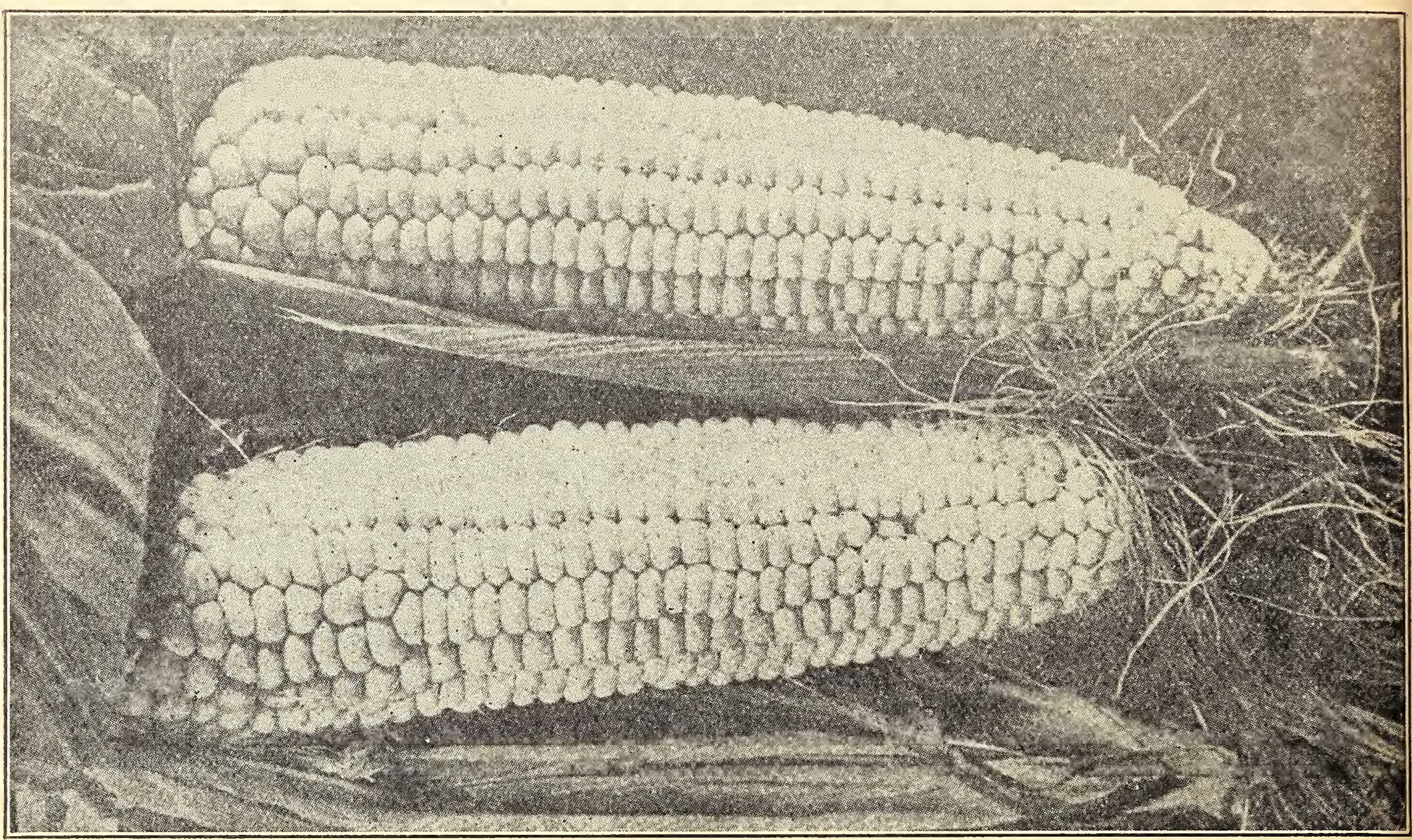

GOIDEN BANTAM

\section{EXTRA EARLY SORTS}

GOIDEN BANTAM. A new variety, by many considered the richest and sweetest of all corns. In eating from the cob the grain comes off clean, no particle of cob adhering. Its extreme hardiness admits of very early planting. so that it may be had for market as early as Cory, to which it is much superior in quality. A tight, firm husk protects the ear from the ravages of disease smut, etc. and from worms. We recommend it unqualified.

PEIR O'DAY. The two points of this remarkable corn, to which we wish to call most particular attention, are its extraordinary earliness and unparalleled stveetness, surpassing in these particulars any other known variety, early or late.

FARIY MINIFFSOF. One of the best and most porular of the older varieties, both for the market and private gardener. Stalk short and bearing two long ears, eight-rowed, very sweet and tender, and shrinks but little in drying.

IRAMINIOTH UVEITE CORZ. An Improvement on the White cory. The ears are twelve-rowed and nearly twice as large as the White Cory and covered with very large white grains of good quality: It is extra early. No market gardener should be without it. Lb., 25c; 2 lbs., $45 \mathrm{c} ; 5$ lbs., $\$ 1.00$.

FXTRA EARIY ADAMS, Very early, small ear.

\section{MEDIUM EARLY SORTS}

HOWIING MOB. Early and a great favorite in the market. Lb., 30c; 2 1bs., $55 \mathrm{c} ; 5$ lbs., $\$ 1.25$.

WFITE MIXICAN. An early sweet corn of very rich and excellent flavor. Ears elght inches long, usually eight rowed; about the same season as Crosby's Early and of better quality than any other early variety of equally large size. $25 \mathrm{c} ; 2$ lbs., 55c; 5 lbs., $\$ 1.00$.

\section{LATE AND MAIN CROP SORTS}

STOWELL'S EVERGREEN. The general favorite with canners, market gardeners and for the hom garden.

NEW WHITE EVERGREFN. A high-bred, ideal type of Stowell's. The ears are uniformly large and well filled to the tip. Its sweetness, tenderness and flavor are unequalled. Both cob and grains in the green state are white as snow.

COUNTRY GENTLEMAN. This is the variety par excellence for quality. It is medium early, rows zigrag, grains long, flavor bejond description. 2yxcellent corn canning.

SHAKER'S EARLY. A very productive variety coming in soon after Early Minnesota, but bearing larger ears and frequently bearing two ears to the stalk. A fine market gardeners strain.

HLACK MEXICAN. A very tender, fine flavored variety, producing $\&$ to 10 rowed ears about 8 inches in length. Although the ripe kernels are deep blue or black, when ready for table use they are white.

\section{POP CORN}

QUEFI'S GOIDEI. A handsome and distinct variety of popcorn, producing large golden ears in zreat abundance. When popped it is of a handsome white appearance and of a delicate flavor. A single grain will often expand to a diameter of nearly one inch.

WHITE PEARI.

WHITE RICE. The popular variety.

JAPANESE HUIL. ESS.

Special Prices on Irarge Quantitles. 


\section{EGG PLANT}

Herpfianze. Auberglne.

CULTURE.-Sow in hot beds very early in the spring and transplant to two or three feet apart, in very rich, warm ground. Hoe up gradually until they blossom.

IMPROVED NEW YORK PURPLE. The best known and for years the leading variety of egg plant. The fruit is large, oval and deep purple in color. A sure cropper.

BLACK BEAUTY. An early maturing variety bearing deep purplish black fruit. The "eggs" are nearly as large as those of New York Purple and mature about ten days earlier.

FLORIDA HIGH BUSH. Plants of this variety grow strong and tall and the fruits are borne high on the bush. It is very prolific and bears continuously throughout the growing season. The blossoms are not easily blighted by the hot sun and the fruit seldom drops to the ground. Fruits are dark and purplish, about the size of Improved New York.Purple, but a little more rounded and of delicious flavor.

\section{ENDIVE}

\section{Endivie. Chicoree.}

CUITURE.-Sow in August in shallow drills, twelve to fifteen inches apart, and thin to one foot in drills. When fully grown tie over the outer leaves of a few plants every week or ten days to blanch.

\section{WIIIY CURIZD. Self blanching.}

GREFIT CURIPD. Leaves curled dark green.

BROAD IEAVED BATAVIAIY. Leaves are broad, thick, green, more or less twisted and waved, with white mid-ribs. It forms large hearts, which when blanched, form one of the best winter salads. Crisp, tender and fine flavor.

\section{KALE OR BORECOLE}

\section{Blaetter-Iohl. Chon Vert.}

The Kales make excellent greens for winter and oring use. Sow the seed about the end of spring nd then transplant and cultivate like cabbage.

DWARF GREEN CURIED. A sort of especial excellence, being a very fine curled variety of yellowlsh-green color, growing very close to the ground.

TALL CURLED SCOTCH. Grows about 18 inches in height and spreads. The leaves are bright green, beautifully curled.

THOU8ATD-EEADED KAIE. Fine for stock and poultry.

\section{KOHL RABI}

\section{Eohl-Rabi. Chon-rave.}

CUITURE. - Same as directed for cabbage, takIng care to set the plants no deeper than they stood in the seed bed, and in hoeing not to heap much earth about them.

PARIIHST WHITE VIELNA. The earliest and best for forcing.

FABIIEST PURPIE VIFITA. Differs from the Early White Vienna only in color, which is bluish purple.

LARGE GREEN. This sort, also known as Large White, is grown for feeding stock. The bulbs when fully grown weigh eight to ten pounds and are stored like turnips.

\section{MUSTARD}

\section{Senf. Moutard.}

YEIIOW OE WHITE IONDON. Best for salad.

BROWI OR BIACR, More pungent than the white.

CHINASE CORIFD OB GIANT, Leaves twice the size of the white.

SOUTHERN GIANT CURLED. The true curled leaf variety.

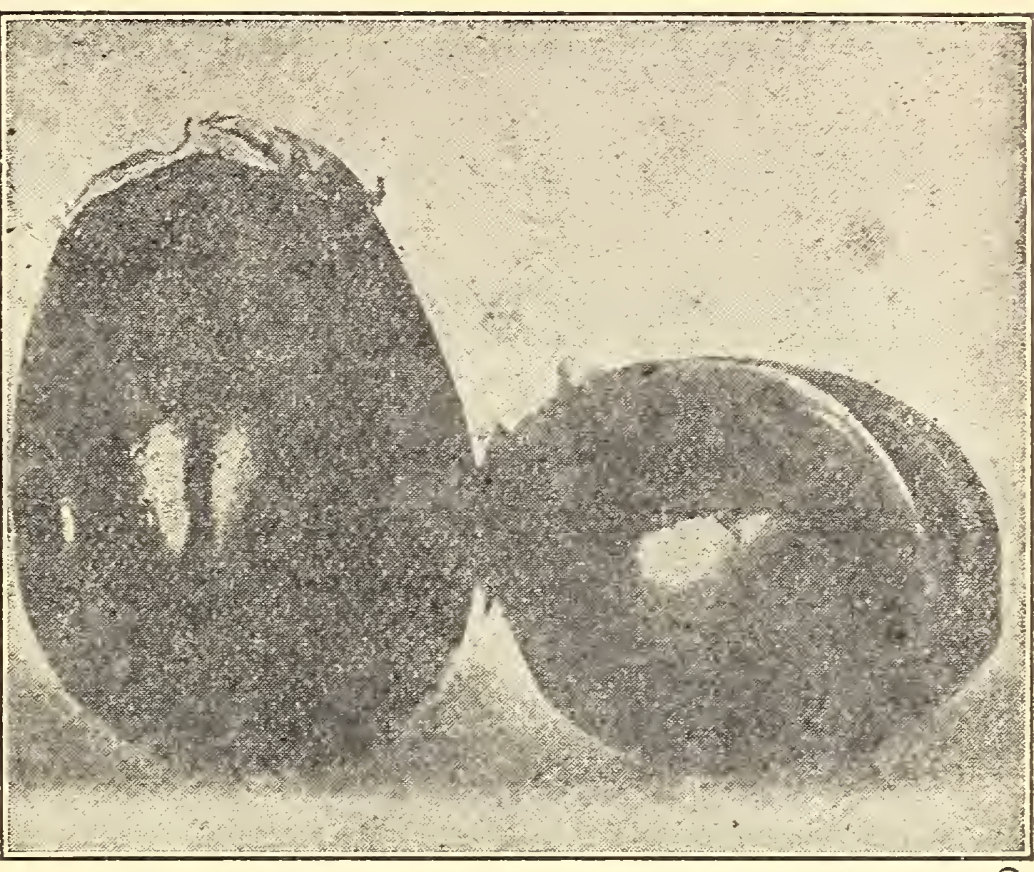

N. Y. IMPROVED PURPLE EGG PLANT

\section{LEEK}

Iauch. Folreau.

CUITURE.- Sow early in spring. When about six inches high transplant into rows about tea inches apart each way and as deep as possible to perfect the blanching process. The richer the soll the finer the leeks will grow.

MUSSPIBURG. Very dark colored leaves, stout and hard.

IARGE AMERICAN FIAG. Pods.

\section{OKRA OR GUMBO}

Ocher. Gumbo.

CUITURE. Sow about the middle of spring in drills, and thin the plants to $a$ foot or more apart. Highly esteemed and cultivated for its green seed pods, which are used in soups or stewed and served like Asparagus.

IONG GEJEN OR IONG WEITE. Long ribbed pods.

MMPROVED DWARF GREFN. Early and very productive. Smooth pods.

\section{MUSHROOM SPAWN}

\section{Charnpignonbrut. Mousseron.}

Mushrooms are much enjoyed as a table uxury. They may be grown in a variety of ituations-a dark room, cellar, stable, in sheds, inder greenhouse benches-where the tempera. ure can be maintained at 50 to 65 degrees. Ten counds of spawn are required for ten reet iquare.

Cultural Direetions.-Two or three weeks beore the bed is to be made, collect a quantity of horse manure, free from straw, and mix an: equal weight of loam from an old pasture with it. Place it under cover, turning it over once. or twice a week until the fiery heat has become exhausted. When the manure is in condition to be made up, lay out the bed, say three feet wide, ten feet long, and make the bed in layers of about one foot deep; press it down firmly as the process of building goes on. When the bed has been made some time, say a week or thereabouts, and the heat is sufficiently declined to a temperature of about 65 or 75 degrees, the spawn may be put into it. Break the spawn in pleces. two inches square, and put them six inches apart, all over the bed, then cover the bed with two inches of rich soll, not too wet or overdry. Cover the bed with a foot of dried straw or hay, and the work it done. If everything goes. on well, you may expect mushrooms in about. five or six weeks. Our leaflet on Mushroom Culture free on request. 


\section{LETTUCE}

\section{Ealat. Ialtuo.}

CUITURב.-For an early crop sow under glass in February ard transplant on a well prepared bed, in some sheltered corner, in April. For successive crops sow in beds of well pulverized soil in March and at intervals of about a fortnight until the end of May.

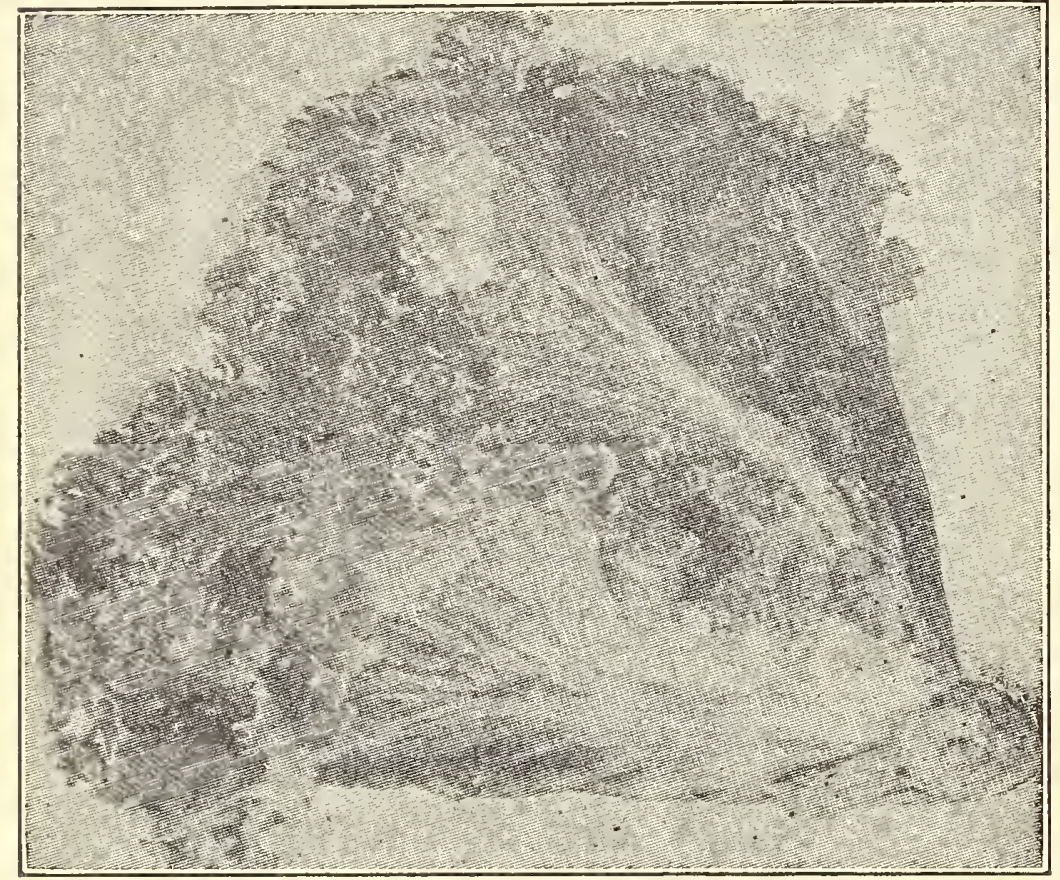

8

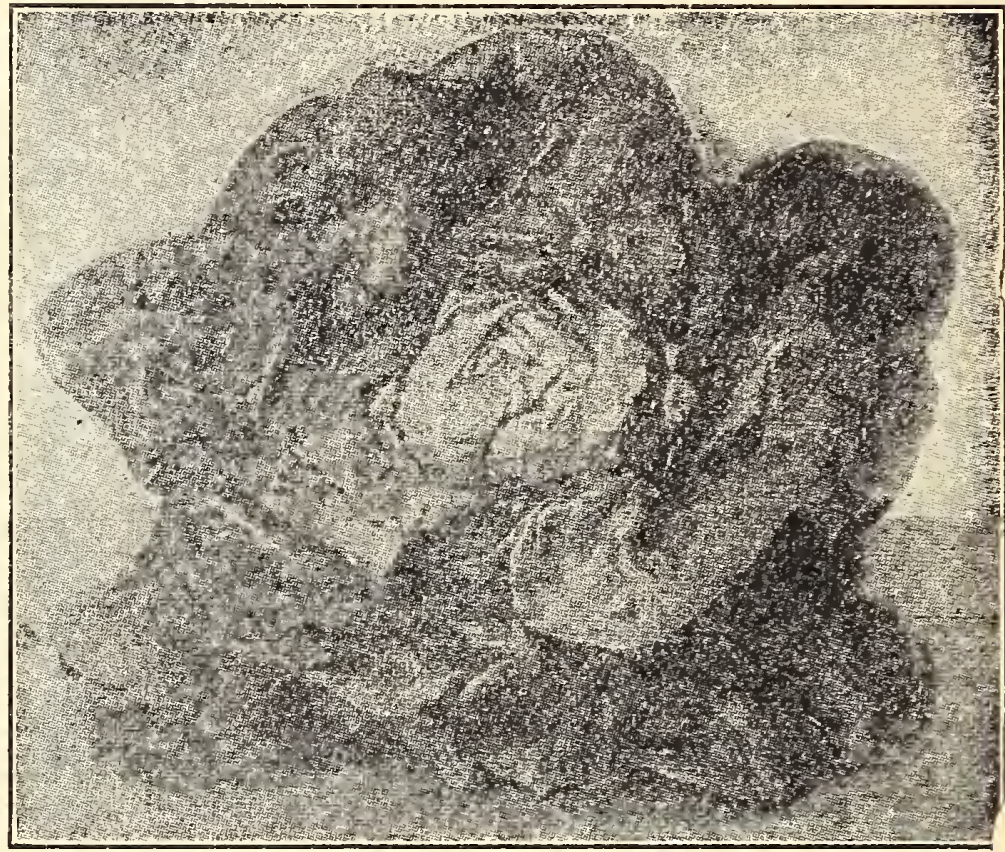

LETTUCE-MAY KING.

GRAND RAPIDS FORCING. The most profitable and most satisfactory variety for greenhouse culture. It is of quick and strong growth, not liable to rot, can be planted closely, is of handsome appearance. Stands shipping better and lasts longer after cutting than any other variety.

BIACK SEFDED SIMPSON. Forms large, loose curled leaves of light green color and remarkably crisp and tender. Equally suitable for hot bed, cold frame or outdoor culture. A most profitable variety for the market gardener.

FARIY CURIPD SIMPSO 3. This variety does not head, but forms a compact, close mass of leaves.

DENVFR MARIRI. An early variety, forming medium-sized loose heads of light green, finely-crumpled leaves. An outdoor summer sort, but used by many for forcing.

PRIZE FEAD. For many years the most popular of the large, loost-headed sorts. The leaves are very crisp and tender and finely-crimped, bright green in color, tinged with brown. Excellent for the home gardner, but too tender for handling on the market.

TEF TRIAINON COS, OR CETERY IFTIUCF. This new varlety from France is by far the best Cos lettuce wo have ever grown, and we recommend it very highly.

EARLY MAY KING.. This valuable new Lettuce comes from Germany. It is, without any question, one of the best Lettuces on the list for

early spring planting in the open ground. The heads are 6 to 7 inches in diameter, with the outer leaves very closely folded in. The heads are of a clear light green, the outer leaves being slightly tinged with brown, the inner being clear, bright yellowish, with a very rich oily flavor.

FANSO1. A very fine heading variety of large size. The heads are very solid, sweet, tender and crisp throughout and entirely free from any bitter taste.

BIG BOSTON. This variety resembles the well known Boston Market, but produces heads aboul double the size and matures a week later. A valu. able sort for open' ground or forcing.

ICFBIRG. The unusual solidity of the heads is insured by the large white main ribs of the leaves, each of which, curving strongly into the center, acts like a truss, making it impossible for the leaves to open outward and expose the center, which is constantly thoroughly blanched. It matters not whether grown to head in the early spring or the hottest days of summer, the leaves are always crisp and tender.

WHITE SEEDED TENNIS BALL. This is a verY popular, medium sized, compact heading variety. Is especially adapted for early outdoor culture, and for forcing under glass. On account of the small com. pact heads, it can be grown more closely than other sorts. It is especially fine during the cool moist weather in early spring and late fall. It is sometimes called "Boston Market."

NFW YORK OR WONDERTUL. For all sections and all seasons. Excellent for mid-summer; one of the best for resisting heat. Heads large, well blanched, crisp, tender and sweet. Slow to run to seed. A popular cabbageheaded sort. 


\section{MUSK MELONS}

CUITURE.-Musk melons grow best in light soil. Plant in hills about six feet apart, mixing in each hill about a shovelful of well rotted manure. Sow about a dozen seeds in every hill, early in May, and when well started thin out to three or four of the strongest plants.

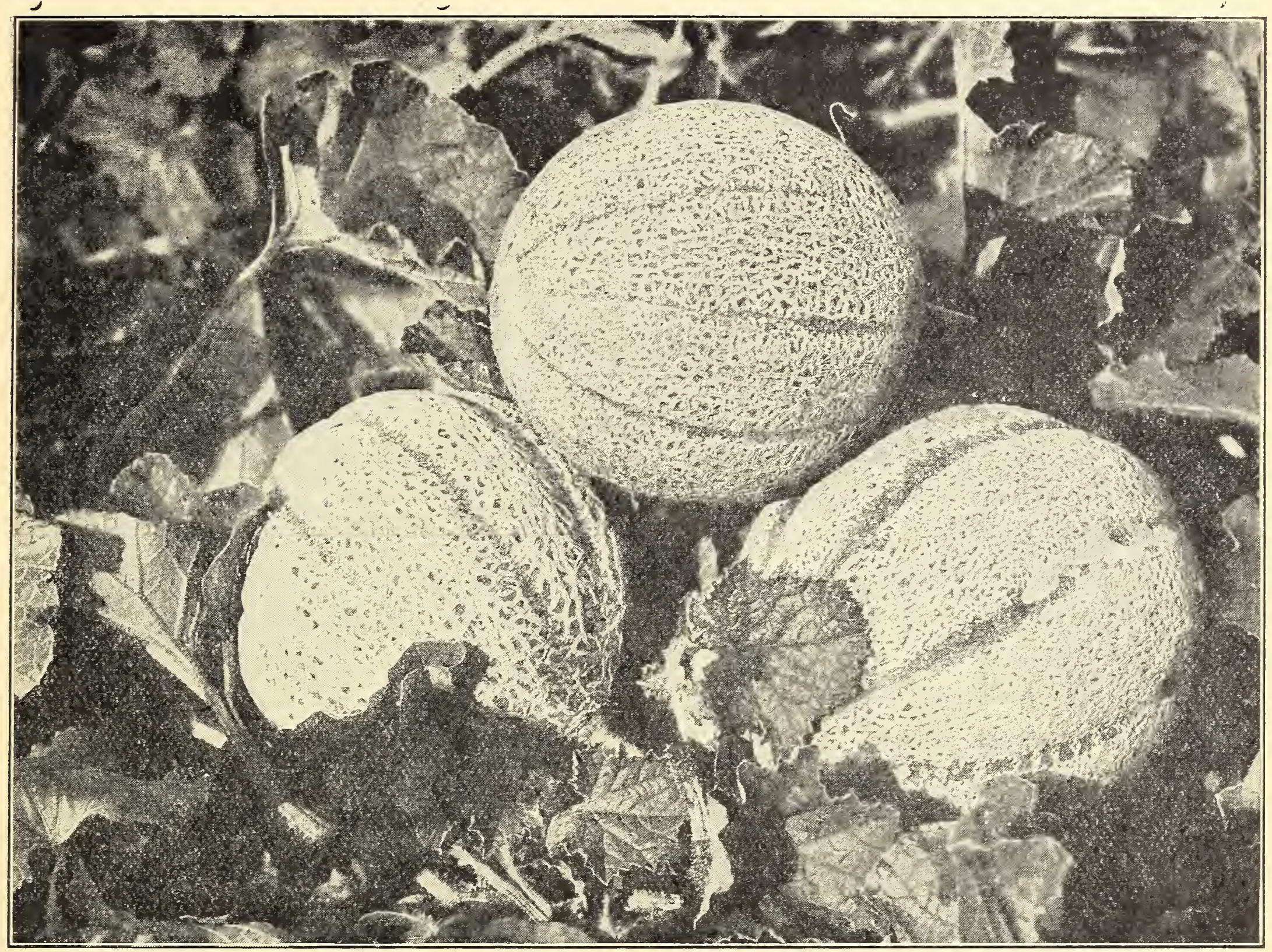

ROCKY FORD

ROCKY FORD. This popular variety sells more readily than any other kind. It is of the netted gem type, but more oval in shape. The surface is very deeply netted and presents a most attractiva appearance. The flesh is green in color, ver thick and of a delicious sugary flavor unapproached by any other variety. Produces abundantly and continuously. Our seed is genuine. from selected and perfect melons, grown by experts a the original home of the variety, Rocky Ford. Colo.

BUREEII'S GFM. This melon has a tough thin rind, well-arched ribs with a closely interlaced gray netting and is protected at the blossom end by a well developed button. The meat is of a reddish orange color, very thick, finegrained and spicy. It is a money making melon for the gardener and a delight to all who love good melons.

NFBRASEA GOID IINED. To the grower of musk melons, whether for the home or market, we recommend this new variety. It is the same size as Rocky Ford, being the result of several years' selection from that popular sort. In shape it is sligthly oval has no ribs, and is heavily netted over the entire surface. Its flesh is bright green with a golden lining next to the seed cavity. The meat is thick, fine-grained and Juicy. Its early maturity, uniform size and shape and excellent shipping qualities make it ideal for the home gardener as well as the large grower.
BOCKY FORD, SALMON TINTED. This melon has been grown for the market intensively, for only a few years but has proven itself to be one of the very best for long distance shipping. The vines are highly resistant to rust. The flesh is of fine texture, deep and very firm. The color is green for one-half the depth from the rind while the other half is a rich salmon, which gives it a very attractive appearance.

OSAGE. A large, orange fleshed melon of unsurpassed table quality and increasing popularity. It is productive, a splendid shipper and commands a good price.

NEW HONEY DEW MUSKMELON. A new type the result of crossing the Rocky Ford with an African melon. The fruits are very uniform in size, about 6 inches in diameter and 7 to 8 inches long. The rind is smooth, dull white, when ripe and tough. The flesh is rich green in color and of a delicious honey-like flavor. The vines are very productive and the melons keep for several weeks after they are ripe.

Also the following standard popular sorts.

Extra Early Hackensack, Large Hackensack, Enerald Gem, Long Yellow Cantaloupe, Acme, Banana, Prolific Nutmeg, Miller's Cream. Paul Rose, Defender, Princess. 


\section{WATER MELONS}

CUITURF.-Plant in hills eight to ten leet apart each way with a shovelfull of well rotted manure mixed with the soil in each hill. Put six or eight seeds in each hill and finally leave when danger from insects is past but three strong plants. Hoe often. If extra large fruit is desired have but two or three melons to the vine.

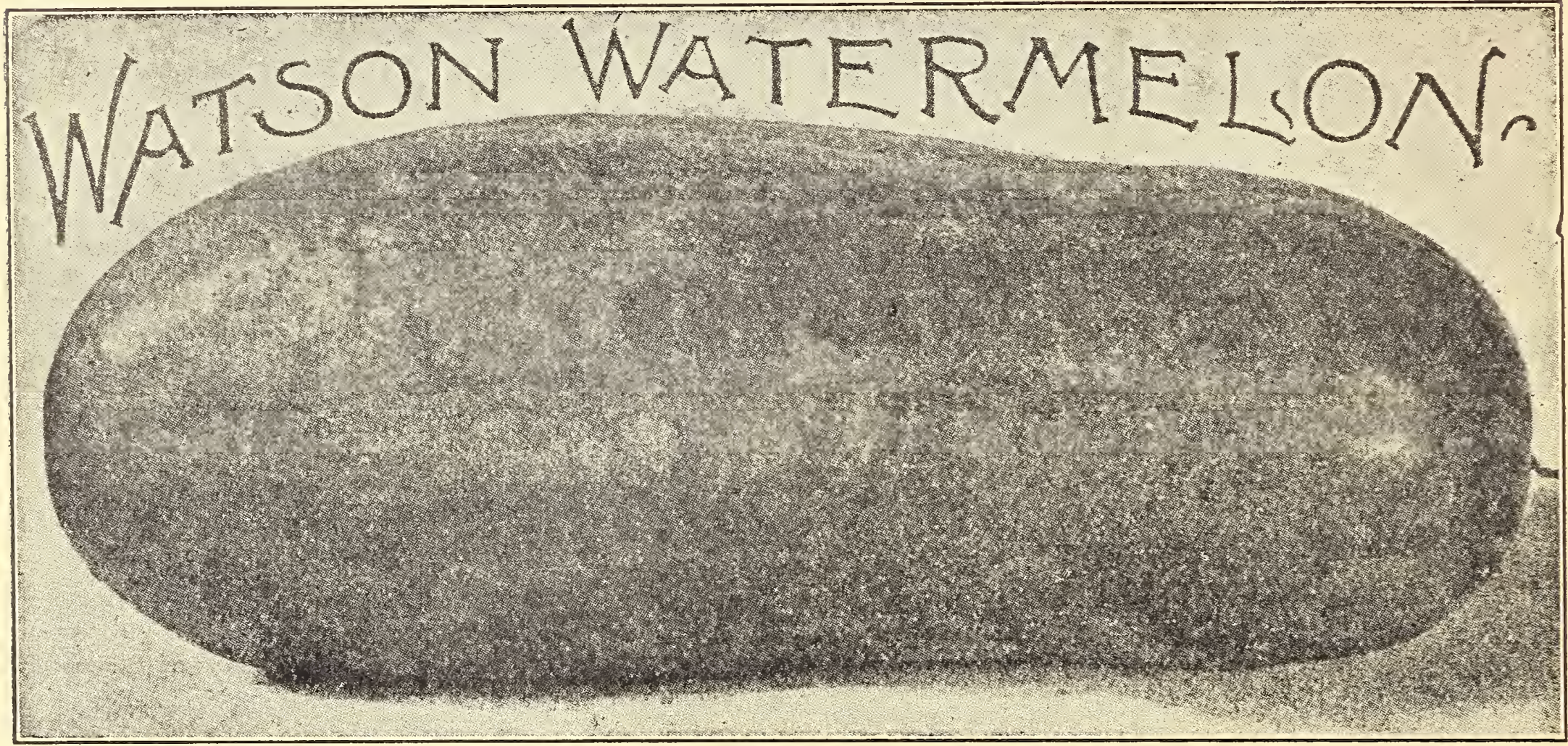

TOM WATSON. Typical fruits of this variety reach a size of twenty-four inches in length and twelve inches in diameter. The rind is dark mottled green, thin but tough enough to endure shipping to very distant markets. Of the long shaped melons it is the best shipper. The flesh is deep red and comes very close-about three-fourths of en Inch-to the rind. The exquisite deliciousness of flavor possessed by the fine quality flesh of this melon places it in the very front rank of melon excellence. For the home or market garden, or for shipping, it is a money maker for the growers. Our strain of this is not surpassed in the market.

SWEETHEART. A delicious melon for home use. Vine vigorous and productive: Iruit large, oval, uniformly mottled light and dark green; rind thin but firm; flesh tender and melting.

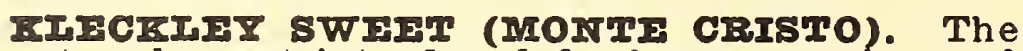
inest melon yet introduced for home growing and table use The fruits grow 18 to 20 inches long and 12 inches in diameter. The skin is a rich. dark green; flesh iright scarlet. The rind is but half an inch thick, so that shipping it long distances is not practicable. The seeds are white, lying close to the skin and leaving a very large, solid heart, crisp, sugary. melting and entirely free from stringiness. The handsome appearance, uniform growth and luscious sweetness make it one of the finest melons in cultivation. Our seed was saved from carefully selected melons, and is strictly pure and true.

ROCRY FORD. A hard shelled shipping strain of Kleckleys.

CUBAN QUEEN. An excellent shipping varlety of medium to large size, and globular to oval shape. Rind quite thin, flesh bright red and firm. Skin striped with light and dark green.

HARRIS' FARIIEST. This excellent watermelon grows rather large for an early variety. slightly oval in shape, skin mottled lisht and dark green. It is uniform in size and shape; the flesh is solid, bright red, very tender and $s$ weet.

IRISH GREY. A very fine melon of uniform large size. Color of rind, Jellowish gray and almost as tough as that of a citron. Ripens earlier than Tom Watson and will keep in good condition for a long time after picking. Very prolific and one of the best shippers. A very fine melon for the market.

TRUI ICE CREAM. The great home-market melon. It has too thin a rind for shlpping. Fow, if any, surpass a True Ice Cream for quality and productiveness. Flesh bright scarlet, solld to center, melting and delicious.

MOUNTAIN SWEET. Early and very large, oblong shape, rind dark green; flesh red solld and sweet, a gigantic variety from whence Its name is derived.

PHINNEY'S EARIT. Very early; flesh bright red, sweet, tender and well flavored. Reliable for market gardeners.

Also the following popular kinds.

Fordhook झarly, Citron, red-seeded, Ironclad.

Halbert's Honey.

Alabama Sweet.

Kolb's Gem

Citron Colorado, green-seeded.

IfcIver's Wonderfu Eugar.
New Triumph,

Vick's Earls.

Fentucky Wonder.

Rattlessake.

Black Spanimh. 


\section{ONIONS Zwiebel. Ognon.} Cofruza. The ground for Onions should be well prepared by digging in plenty of well-
rotted manure. The seed may be sown from the first of April to the middle of May. Sow in drills one inch deep and twelve inches apart. When the onions are up thin them out to a distanca of three inches apart.

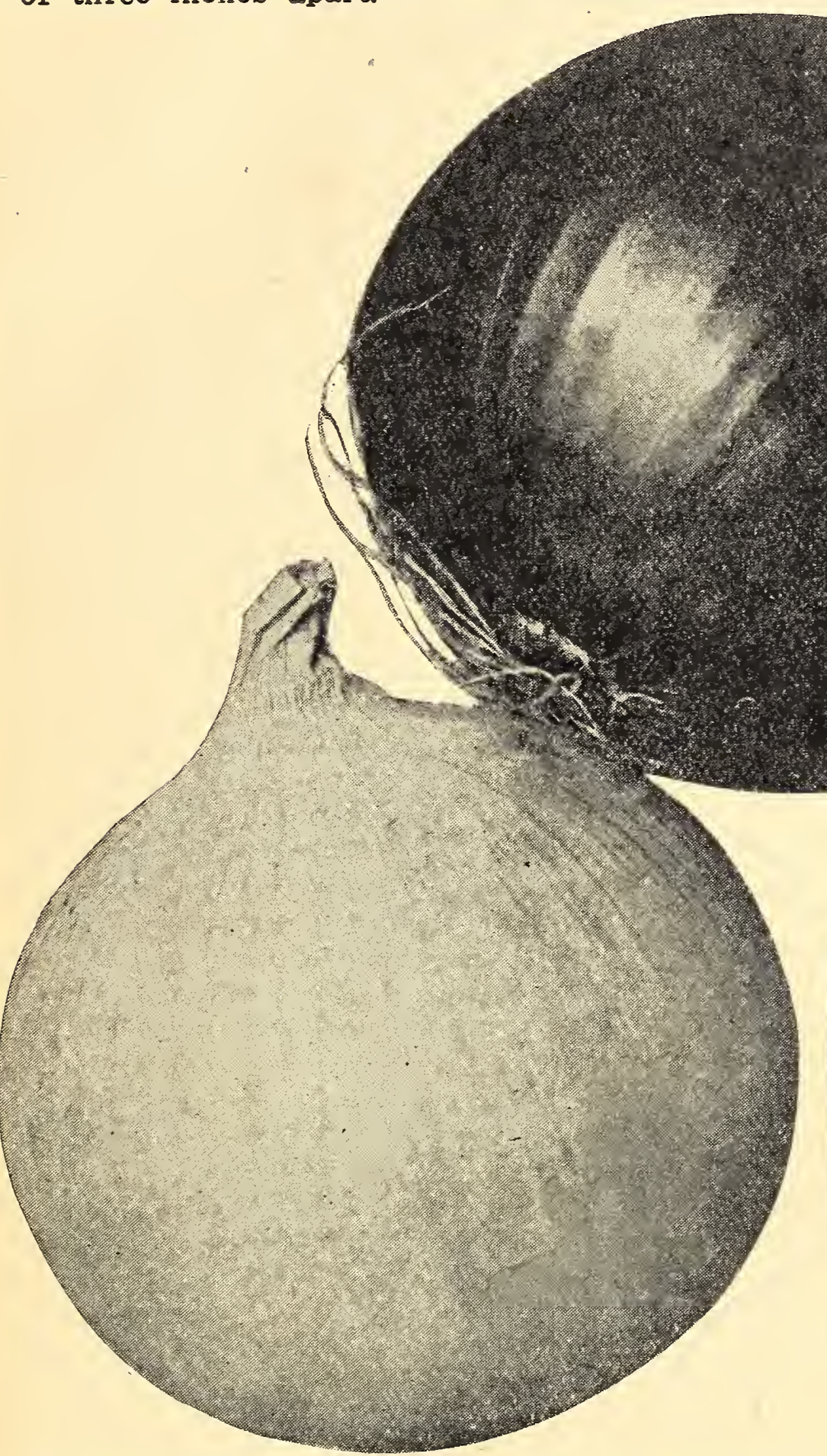

SOUTHPORT IARGI RED GIOBE (Seiected Btock). This is the most perfect market type of Red Globe Onion. It is of large size. deep crimson in color and of mild flavor. Our seiected stock excells all others in earliness, productiveness, perfection of shape and long-keeping qualities. Choice new seed.

IARGE RED WFrHFRSIFID. The standard red variety and the favorite onion in the West, where Immense crops are grown for shipment. Large sized, skin deep purplish, form round, comewhat flattened. Flesh purplish white, moderately fine grained and stronger flavor than any of the other kinds. Very productive, the best keeper, and one of the most popular for general cultivation.

32TRA BARII RED FIAT. A medium-sized ant varlety, producing abundantly and coming into ase about two weeks earlier than Red Wethersfleld.

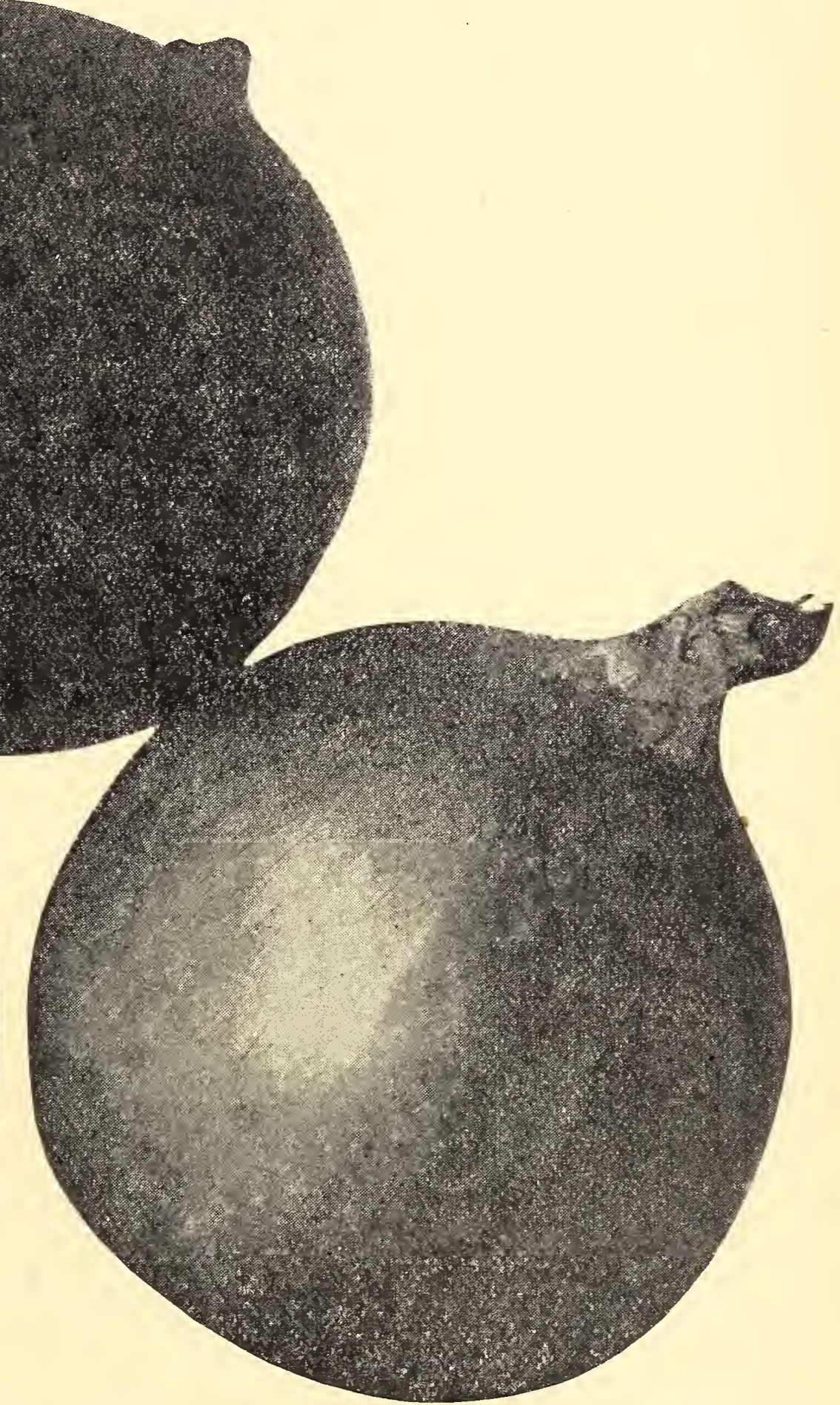

SOUTHPORT IARGI WHITI GIOBE. This is one of the finest onions in cultivation, both in appearance and quality. It is large, globe shaped, firm, fine grained, and of excellent flavor, and commands a higher price in the market than any other white onion grown. Its skin is pure white, and its keeping qualities particularly good.

MAMMOPH SIIVPB KING. The largest onion in cultivation. Has been grown extensively in the past few years in all sections of the country. especially in the West, and has given universaj satisfaction.

PEITADPIPEIA SIIVPRSKIN (White Portagal). A large flat onion of mild flavor with a beautiful white glistening skin. A good keeper and much used for bunching and for pickles. Par. ticularly desirable for isets.

PARIS WEITI PICKIING OR SMAII SIIVRBSKIN. For pickling. This is of small size, silvery white, and used almost entirely for pick: ling on account of its small size. 


\section{ONIONS-CONTINUED}

PRIZE TAKER. This is one of the best of the huge foreign varieties. When started early under glass, and transplanted into open ground, they bottom fairly well, are nearly free from stiff necks, and when offered for sale always attract marked attention. This variety is without a doubt the largest onion grown, samples under special culture sometimes weighing five pounds. We offer this season American grown seed.

DANVERS YILIOW GLOBE. Distinct in form, being nearly globular, of a beautiful golden yellow. Mild flavor and good keeper.

DAIVIRS YrIIOW FIAT. This fine variety is a thick, flat, straw colored onion, mild flavored, yields aboundantly, ripens early, and keeps equal to the best.

AUSTRAIIAN BROWI. This new onion is of neat, round shape, medium size, with skin of a deep amber brown, distinct from all other unions, extremely hard and firm, of fine flavor and will keep almost indefinitely. Australian Brown is the only onion Australian growers will plant. We offer choice Australian grown seed from the original importation.

TEE IN .S. CO.'S PICKLING. For early buncning, pickling or sets, the finest strain offered. This may seem a broad statement, but for these purposes we have never sold or seen its equal

WIITE QUEFN. A very early variety, white, small and fine flavor.
YEITOW DUTCE OR STRASBURC. Ripens early and forms large bulbs rather flat in shape with outer skin of bright straw color and mild creamy white flesh. We recommend this variety on account of its excellent keeping qualities.

SOUTHPORT YELLOW GLOBE. A very hardy and proudctive late variety of the same general character as the Southport Red Globe but the skin is yellow and the bulbs are a little larger and later maturing. The globe shaped bulbs ripen very evenly, are excellent keepers. The flesh is white. mild and of excellent flavor.

Onion seed is one of our leading specialties. We grow ourselves a large portion of the seed we sell; the remainder is raised by expert onion seed growers under our supervision. We are the largest growers of onion sets in the West and use all unsold seed for sets. We are thus enabled to offer our customers absolutely fresh seed every year. Grown only from the choicest selected bulbs under expert care, our onion seed is always thoroughly reliable. Special prices to gardeners and others using large quantities.

\section{ONION SETS}

\section{Prices Subject to Market Fluctuations WHITE BOTTOM SETS.}

RED BOTTOM SETS.

YELIOW BOTTOM SETS.

RED TOP SETS.

EVERGREEN TOP OR WINTER ONION. ThEY are planted in september.

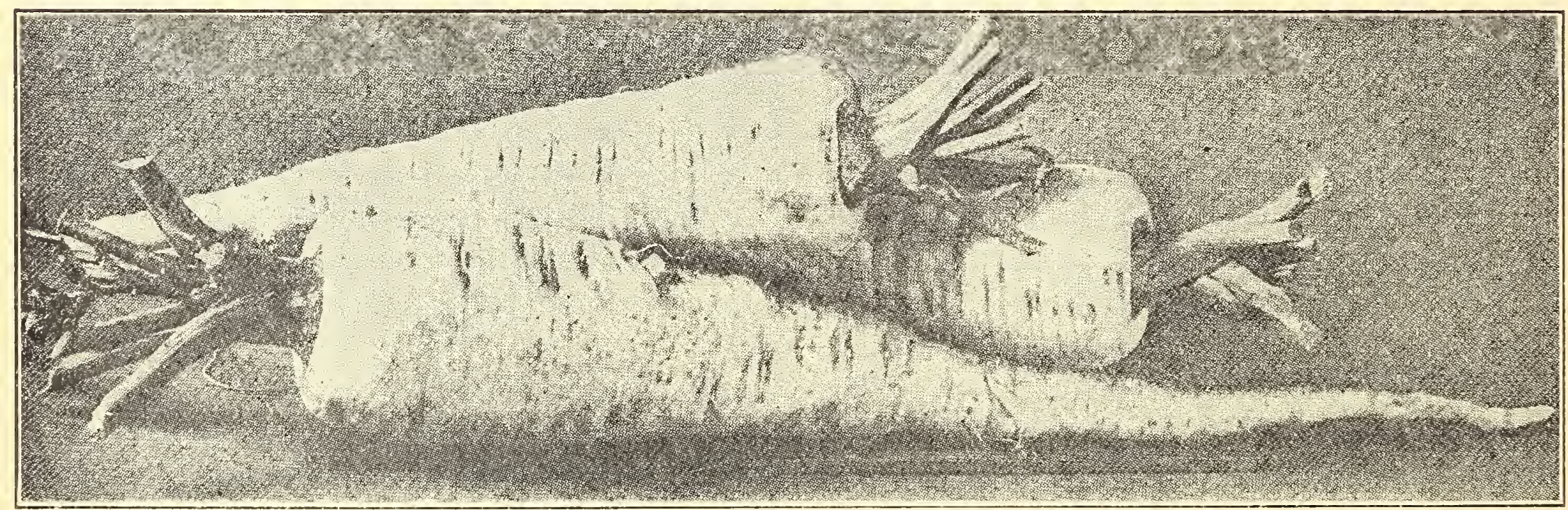

\section{PARSNIP}

\section{Pastinake. Panais.}

CUITURE.-Sow as early in the spring as the weather will permit, in drills 15 inches apart, and half an inch deep, in rich, well-manured ground. well dug. Cultivate similar to carrots and thin out to six inches apart in the rows.

GURRNSEY, OR FAII IONG. As name indicates, not as long as the Hollow Crown. Quality very sweet and delicate.

HOJIOW CROWIT, OR IARGI SUGAR. The largest variety in cultivation. Roots long, white, smooth, tender, sugary and of excellent flavor

\section{PARSLEY Petersilie. Persil.}

CUImTIRF.-Parsley thrives best in a rich soll.
The seeds germinate very slowly, three to fous weeks generally elapsing before it makes its ip. pearance. Sow early in the spring, half an moch deep, previously soaking the seeds for a few hour: in tepid water.

DOUBLE: CURIED. This is an English variety of quick, robust growth with leaves so much curled as to give thern the appearance of muss It is rich green in color and of excellent flavor. It is slow to go to seed and very hardy.

CEAMPION MOSS CURIED. A compact grow ing, finely curled variety of a bright, slightly yellowish green color

PLAIN. This is the hardiest variety.

HAMBURG, OR TURNIP ROOTED. Fleshy rooted. The roots are used for flavoring soups 


\section{PEPPER}

CULTURE.- Sow early in hot bed, or in open sround about the middle of spring. Transplant when three inches high, to one foot apart, in drills twenty inches apart, and earth up a little in hoeIng, which can be continued until the plants are in zuli bloom

PIMENTO. A new introduction of the oimento type, very smooth and uniform in shape. The flesh is much thicker than in the various "bell" peppers, ylelding a half more edible portion and also making the fruits easily peeled. The flesh is sweet and delicious being entirely free from pungency. The plants are very prollfic, producing heavy crops untll killed by frost. In view of its many superior qualities we expect to see Pimento become the leading variety of Pepper.

RUBY GIANT PEPPER. This beautiful Pepper is a cross between the Ruby King and the Chinese Giant. The Chinese Giant is the largest of all Peppers, but is rough and ungainly in shape; whereas the New Ruby Giant, while quite as large round as the Chinese Giant, has the ideal shape of the Ruby King, being longer than the Chinese Giant, and much larger round than the Ruby King. Plants vigorous in growth. The flesh is mild, sweet as an apple, making a good salad sliced and served with Tomatoes.

RUBY KING. The fruits are about 5 to 6 inches long by about $3 \frac{1 / 2}{2}$ inches through. They are bright red, remarkably mild and pleasant in flavor, hav. ing no fiery taste. The most popular red pepper.

SWFET MOUNTAIN. Larger, milder and more productive than Bull Nose. Color deep green, turning to red when ripe.

NEAPOLITAN. The earliest of all Peppers, coming in fully two weeks earlier than Ruby King and Bull Nose. Flesh thick and mild Fruit of medium size; very prolific.

IARGE BEII OR BUII IOSE. A large, thlok fleshed, mild variety, used for stuffing and for mixed pickles.

CAYEN2E. Long red hot and pungent.

CFIII. Like C'ayenı́, but smaller and later used for pepper iauce.

\section{SPINACH}

\section{Spinat. Epinard.}

CUITURE-This is one of the most important of our market garden crops and one that requires very little care. For summer use sow at intervals of two or three weeks from April to August, and for early spring crop sow in September, covering it in exposed places with straw to brotect it from severe frost.

BIOOMSDAIF CURIFD SAVOY-IEAVED The leaves are crinkled like Savoy Cabbage, from whence the name; it is a very valuable variety. particularly for market gardeners.
ROUND TEICK-IFAVED VIROFIAY. Excel lent market sort; equally good for spring and fal sowing; leaves large, thick and fleshy; in general use for early spring planting; also for fall sowing

KING OF DENMARK. - A new Savor leaved spinach which stands longer before going to seed than ang other variety. One of the best and most prolific market sort; leaves rery large and juicy and wrinkled.

\section{SALSIFY OR OYSTER PLANT}

\author{
Bocksbart. Salsifis.
}

CULTURE-Sow early in the spring in drilis 14 inches apart. Culture same as carrots or parsnips.

MAMMOTH SANDWICE ISTAND. A neW and large growing variety of best value to the market gardener.

\section{HERBS}

\section{Sweet, Pot and Medicinal.}

No garden is complete without a few herby for culinary and medicinal purposes, and car should be taken to harvest them properly. This should be done on a dry day, just before the: come into full bloom, then dried quickly anc packed closely, entirely excluded from the air Sow in spring in shallow drills one foot apart and when well up thin out and transplant to a proper distance apart.
ANISE (Pimpinella Anisum). Used for cor. dials; also for garnishing and seasoning.

BORAGE (Borago Officinalis). For flavoring excellent for bee pasture.

CARAWAY (Carum Carfi). Used in pastry confectionery, etc.

\section{CATMIP (Neptea Cataria).}

DIII (Anethru GraveoIens). Used in mak ing pickles.

FENNFI, SWEET (Anethum Foenicuinm) Ornamental leaves.

EOREFOUND (Marrubinm Vulgare). FOE making cough remedies.

IAVEIDER (Iavendula Vera). Aromatic med icinal herb.

MARJORAIM, SWEET (OrIgantum Majorana) Desirable for seasoning.

ROSFMARY (ROsmarinus Officinalis).

SAGE (Salvia Officinalis). Extensively used for seasoning.

SUMMER SAVORY (Satureja Fortensis). EXtensively for seasoning.

THYME (Thymus Vulgaris). Extensively used for seasoning. 
INOCULATE THIS SEED

\section{PEAS}

CUITURE-The planting of an early crop of Garden Peas should be made in the spring, as soon as the ground can be worked, in a warm, dry location and covered about 3 inches. They are usually planted in double rows three to four feet apart, and, those requiring it, bushed when about six inches high. The large and later sorts do better at a greater distance apart, leaving a broad space for planting low growing vegetables between.

\section{EXTRA EARLY VARIETIES}

MPBBASKA IIGEHMITG (30 inches). No extra early peg has ever given the universal satisPaction among market gardeners that this one has. It is without doubt the earliest and most productive pea in existence, being ready for use 42 days from planting. They ripen up so uniformly as not to require over two plckings to clean up the entire crop. The pods are well filled and the peas of fine flavor.

AIASKA OR FARIIEST OF AII (28 Inches). The earlist of all the Blue Peas. Very productive; pods filled with peas of good size that retain their color after cooking. This is distinctively a market gardener's sort, as it can always be picked in two pickings.

THE NEBEASTA SEED CO'S FIRST ATD BEST (30 inches). Vines small, bearing three to seven stralght handsome pods, each containing six to eight medium sized round peas of good qual1ty. The stock we offer is especially grown for us.

MARVII* (15 inches). A new extra early wrinkled pea of dwarf even growth and great productiveness. The vines average fifteen inches in height with ample, though rather small, dark green foliage and are heavily set with fine pods, frequently in pairs. The pods are rounded and well filled, being blunt or square at the bottom, two and one-half inches long, and contain six or seven quite large dark green peas. In season it is fully as early as Nott's Excelsior and a much better cropper. On account of its very desirable habit of growth, its productiveness and the firm, well-filled pods, it is a distinct acquisition either for the home garden or for the market gardener who desires an early good crop of fine quality wrinkled peas. Most highly recommended.

AMRRICAN WOIVDR* (10 inches). Of fine quality and flavor, and wonderfully productive. Its great distinctive feature, however, is its compact and dwarf growth.

M'IEAN'S IITXIE GEM* (16 inches). A dwarf, prolific, green wrinkled marrow, habit simllar to the Tom Thumb. It has all the sugary flavor of the late wrinkled peas.

CARTrR'S PRIMIUM GFIN (16 inches). A valuable extra early dwarf, wrinkler pea, robust in growth with long pods.

GRADUS* (30 1nches). A grand new extra early wrinkled variety with pods of a beantifu light green color and as large as those of Tele phone The pess are large sweet and meltingly tender and retain their color and handsome appearance after cooking. Its hardiness, productiveness, attractive appearance and high table qualfty make this the most desirable pea to date

PILOT* (36 inches). An excellent pee to use for following the smooth seeded varieties. The pods are of a deep emerald color, long and straight or but slightly curved, are borne in clusters and come to maturity before Gradus. The peas are sweet and of luscious flavor when cooked. The handsome appearance of the pods makes it a first-class market varietv.

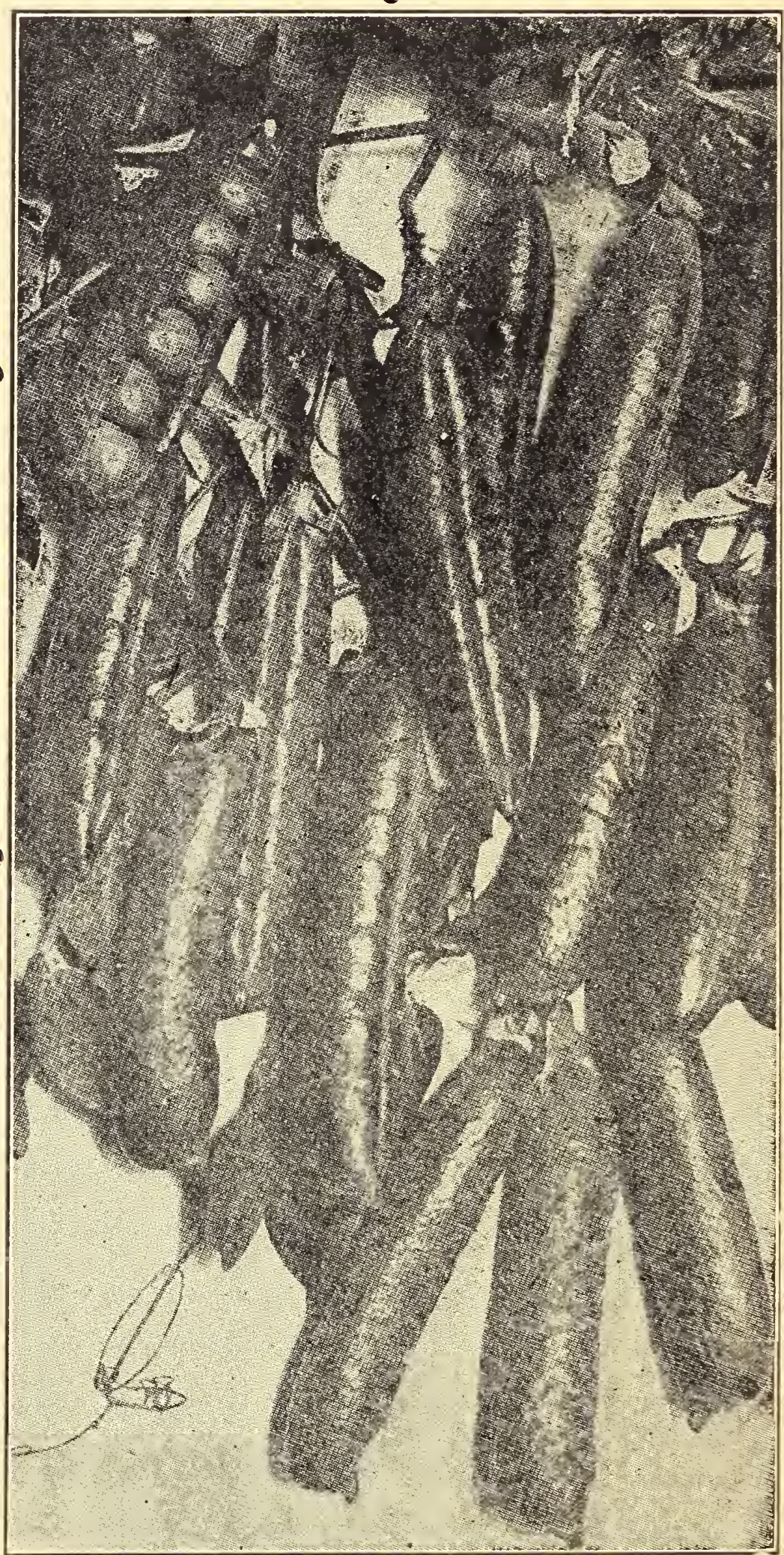

NOTT'S EXCELSIOR

NOTT'S EXCEISIOR* (15 inches). Pods are square and chunky, always containing from five to seven large peas, packed so closely together in the pods that the peas are always more square than round. It grows to a uniform height, and is at all times very tender and of fine flavor. $\mathbf{L b}$. 


\section{SECOND EARLY VARIETIES}

BIISS IVFRBFARING* (28 inches). The vines are very prolific. As many as one hundred pods have been counted on a single vine.

TIE IN. S. CO.'S FAVORITE* (30 inches). The seeds are white wrinkled, of vigorous growth, branching habit, prolific, pods large sized, which grow in pairs well filled with large peas of fine quality.

\section{LATE OR MAIN CROP VARIETIES}

ADMIRAI DEWEY. Vines vigorous, about 4 feet high. Pods usually borne in pairs, curved, bright green crowded with six to nine peas of the very best quality and color. We know of no pea which remains palatable longer after it becomes large enough to use. Seed much wrinkled, of medium size, cream color. Uwing to its great vigor, productiveness, fine color, quality and suitable size of the green peas, it is admirably adapted for canners' use.

PRIDF OF TEF MAREgT (24 inches). Vines tiff with large, dark green leaves, bearing at the top, generally in pairs, a falr crop of very large. dark green pods well filled with large peas of good flavor.

AIDFRMAR* (48 inches). Slightly later than the ordinary Telephone type. The pods are of $1 \mathrm{~m}$ mense slze, the largest of all peas. For exhibition purposes it has no superior. Should be orushed or poled for best results. The peas are very large, sweet and sugary. Quite prollfic. A splendid shipper and we recommend this to all large pea growers.

DWARE CEATEPIOI* ( 84 Inches). The Champlon of England has long been a standard variety; the long vines, however, were an objection. This variety is hardy and of fine quality, but has less vine and produces larger pods and more of them; height, 2 feet.

DWABF FमIFPEONF* (18 Inches). Grows one and one-half or two feet in height, very tock, heavy, vigorous vine; productive. Pods are long and remarkably woll nlled. Peas are large and wrinkled.

IMPROVID BHRATAGFM (18 Inches). Green, quare, wrinkled, vigorous, branching habit. $\mathrm{Re}$ markably luxuriant follage, leaves unusually large. Pods long, well filled with from seven to nine peas of enormous size.

TFIFPHONI* (40 inches). Vines very strong. It branches considerably, the branches bearing from three to five pods. The pods average six to seven large wrinkled peas, of the first quality.

POTIATCE OR BIG DINTTIR PEA (18 inches). A wonder in productiveness. The seed is similar to Pride of the Market, bu somewhat more dented. Pods like Telephone. The erowth of the vine is arnidy and the rods are borne in pairs. No variety known will produce more pods, and no pods could possibly shell out better.

CEAMPION OF FNGIAND* (50 iuches). Un' versally admitted one of the best peas grown

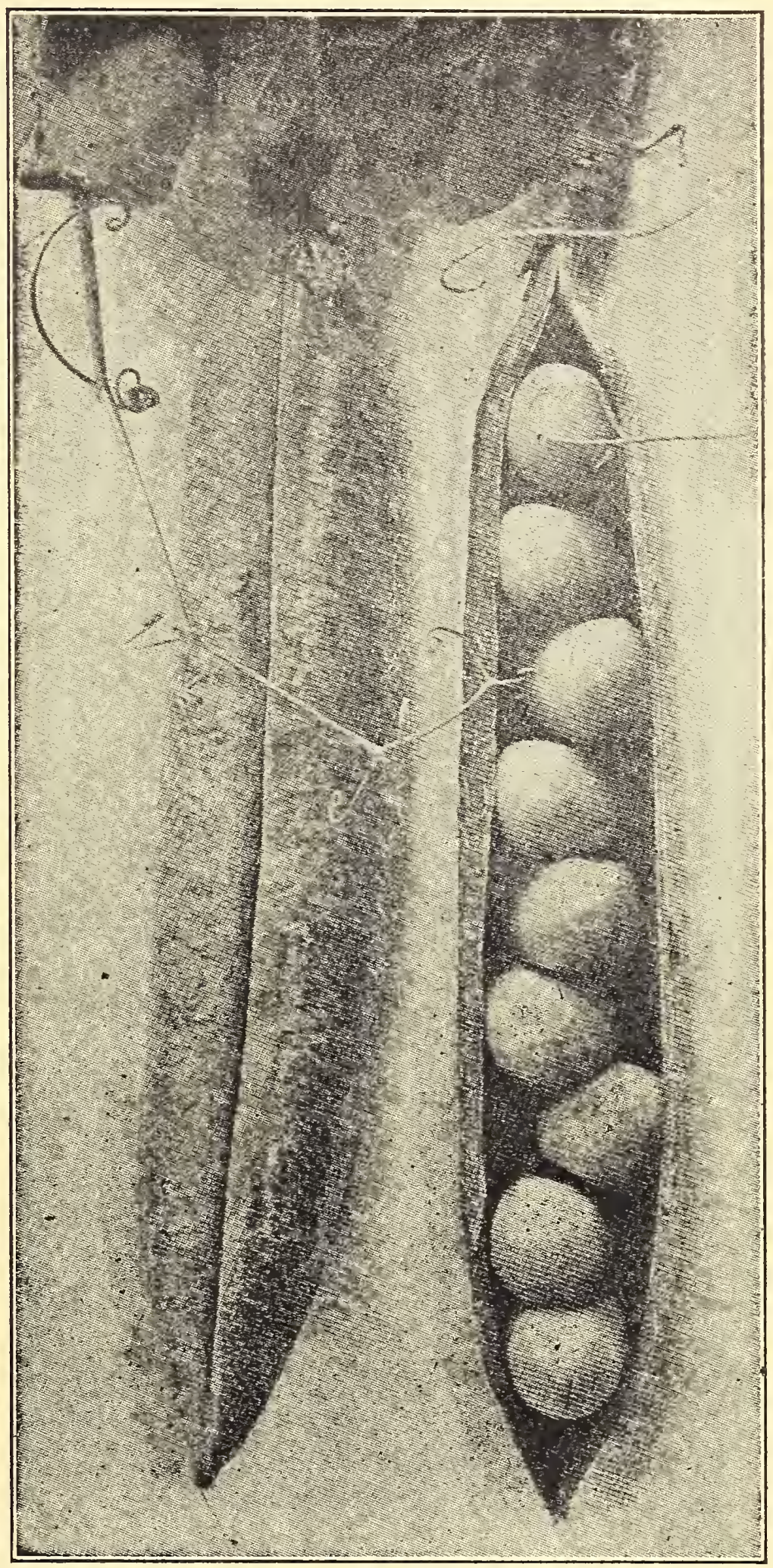

ALDERMAN

IONG ISIAND IMARROWFAT (36 IncheE) Used profitably by market gardeners in New Jersey in place of the old White Marrowfats; belng productive, more showy in the basket and far better in flavor, the pods having somewhat th appearance of Telephones, but are earlier by four or five days, being ready to pick for market in sixty days after germination.

IARGE WHITE IMARROWFAT (36 inchos) One of the oldest varieties in cultivation and favorite market sort.

BIACR EYED MARROWFAT (36 inches). An excellent variety.

\section{EDIBIE PODDED SORTS}

IMPROVED SUGAR MARROW. Belng hardy may be planted early and will produce plants of strong upright habit. The pods, which are prepared like wax beans, are stringless, and when cooked are tender sweet and delicious.

DWARF GRAY SUGAR. Similar to the above but dwarf in habit, growing 15 to 18 inches in height. 


\section{RADISHES}

\section{Radieschen. Radis.}

CUITURE-For a successive supply sow from the middle of March until September, at intervals of two or three weeks. For an early supply they may be sown in a hot bed in February, care being taken to give plenty of ventilation, otherwise they will run to leaves.

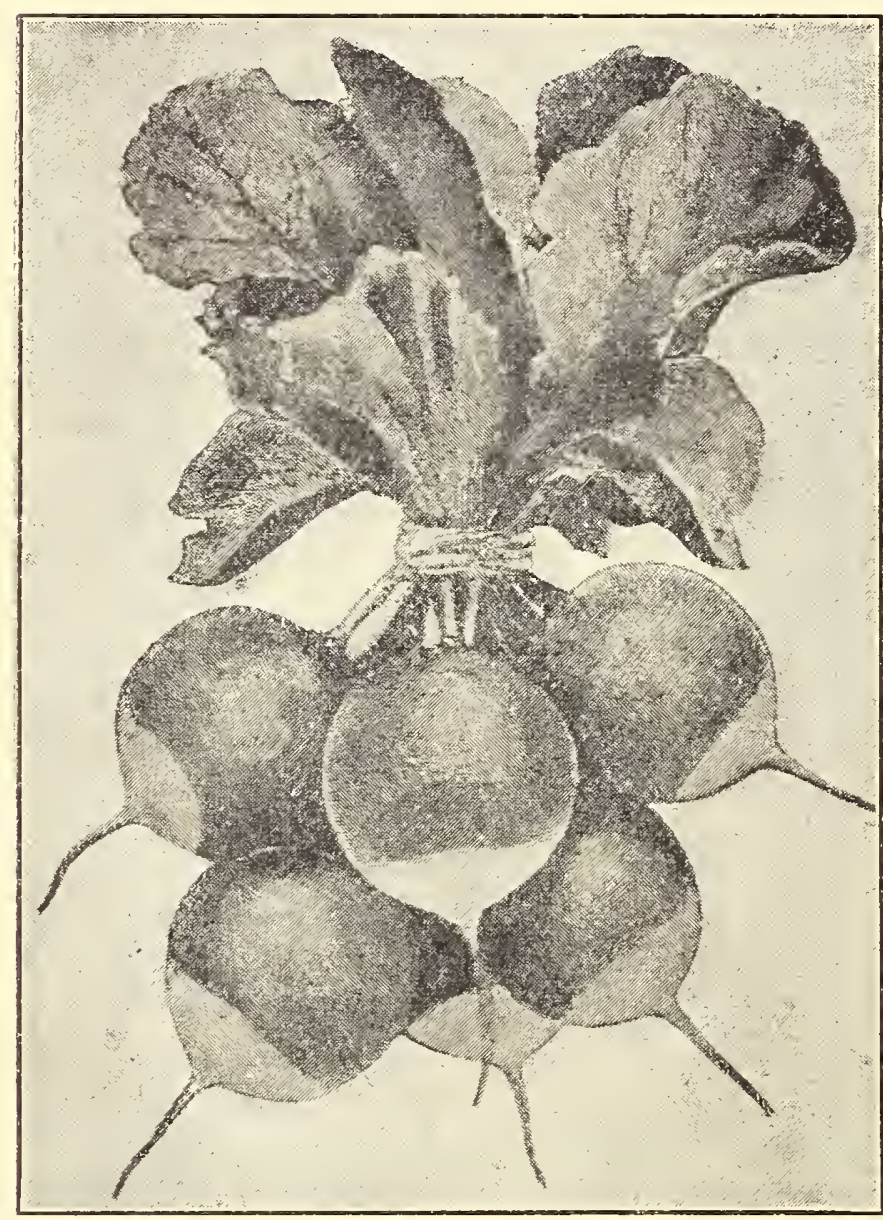

SCARLET TURNIP WHITE TIPPED

SPARIIIR. A white tipped variety that is destined to become very popular on account of its ttractive appearance and excellent quality. The solor is a rich carmine scarlet with a pure white tip, the roots are solid, crisp and sweet and remain fit for use a long time.

PAREI SCARIET TURNIP, WEITE TIPPED. Very early; color bright scarlet, tipped with white, an excellent market variety fine for forcing. Their shape is perfectly globular with rich deep scarlet top, blending into pure white at the bottom. Tender, crisp and delicious.

RADISI, "CRIMSON GIAINT." This radish is an entirely new type and differs radically from all varieties hitherto in cultivation, in so far as its roots attain more than double the size of those of other forcing varieties, without getting pithy or hollow. It is very early notwithstanding its size. Color crimson, flesh pure white, of the best qualsty. Fine for outdoors and forcing The seed should be sown very thinly to permit full development of the roots.

EARIY SCARIET GIOBF. one of the quickest growing and handsomest extra early radishes in cultivation. It is crisp and tender, while its perfect globe shape leaves nothing to be desired.

EARIY DEFP SCARIFT TURATP A small round red turnip-shaped radish. with a small top and of very quick growth. Mild and crisp when young.

FREMCH BREARFAST. Bright rich carmine color with clear white lower portion; very tender and mild.

WEITE ICICIE. A fine long, pure white and very early sort, ready in 20 to 25 days after planting. Its small foliage makes it most desirable for forcing. The snowy whiteness of the roots. their crispness and fresh mild flavor, make

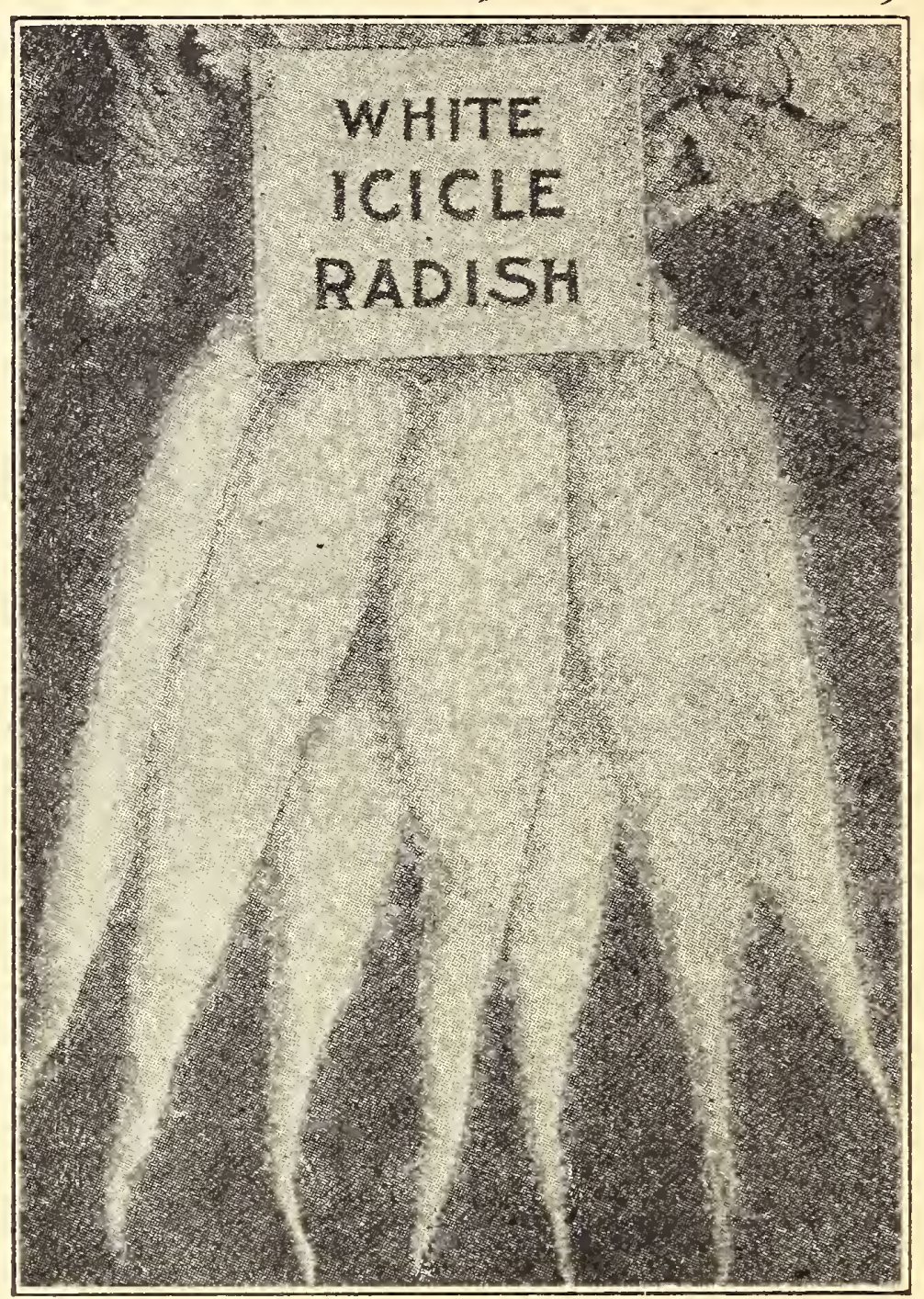

it one of the very finest for market or table.

IONG WHITF VIENINA OR IADY FINGER One of the best long white radishes.

IONG SCARIET SEORT TOP. Standard sort grown for private gardens and for market.

LONG BLACK SPANISH. The skin of the Black Spanish Radish is almost black on the outside, but the flesh is pure white, very hard and crisp, and of pungent flavor. Keeps well all winter in sand.

ROUND BLACK SPANISH. Similar to the long except in shape, which is indicated in the name.

CHINA ROSE, or SCARLET CHINA. This is more largely planted as a winter radish than any other variety. This skin is a bright scarlet flesh pure white, crisp, hard and pungent. Oval in shape.

CEARTIER OR IONG ROSE. TIIITE TIPPED. A very distinct variety, being dark red at the top, and merging into pure white at the base. It stands well and will grow to a large size before it is unfit for the table.

Also the following well-known standard sorts.

Farly White Turnip. TRos $\nabla$ Gem.

Giant White Stuttgart. Half Iong Deep Scarlet. White Strassburg.

Philadelphia White Box. Callf, Mammoth Winter. 


\title{
SQUASH
}

\author{
Kuchen Kuerbis. Courge.
}

CUITUIE-Plant in hills, in well prepared ground, mixing plenty of well-rotted manure ly each hill. Light soils are best suited for their growth. Plant six to eight seeds in each hill and thin out to three or four after they have made partial growth. Plant bush varieties from three to four feet apart each-way, and the trailing sorts six to eight.

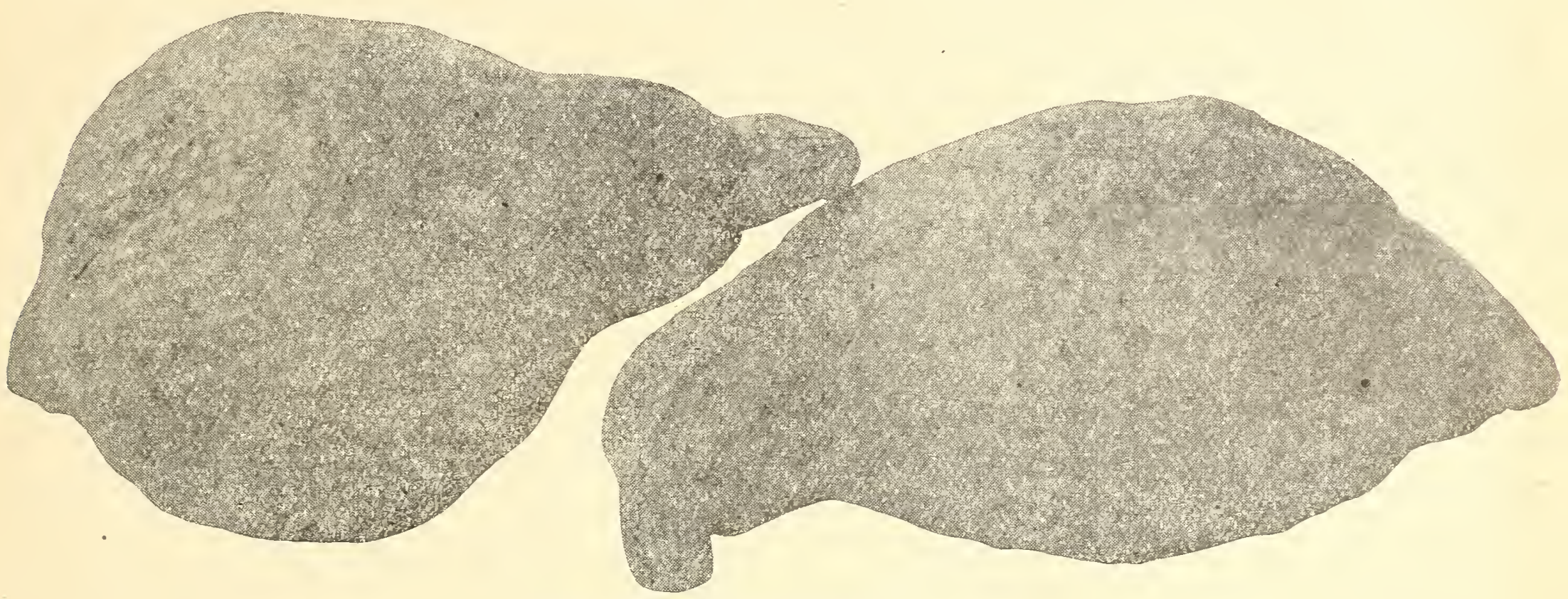

CHICAGO WARTED HUBBARD

PIEE'S PIAT OR SERIEY, A very vigorou= and productive old standard variety. The fruits are large, oval in shape, the blossom end taper. ing. The color outside is dark green and inside the flesh is light yellow and of superior quality

EARLY WHTTE BUSH. The best strain of white scalloped squash in existence. It grows to a large size, and in quality it is simply delicious

CHICAGO WARTED EUPERD. A new, very large strain of the old Hubbard, retaining all of its good features with the added merits of larger size, increased productiveness, and a hard, green, warty shell, rendering it the best keeper of all

IMPROVED EUBBARD. An old favorite, stili retaining its place as one of the best winter squashes; vines luxuriant, healthy and very productive; fruits dark, bluish green, 10 to $25 \mathrm{lbs}$ each; flesh rich yellow, always richly flavored, sweet and dry, whether boiled, steamed or baked; good keeper.

RED OR GOIDEN FUBBARD. A perfect type of the Green Hubbard, except in color, which is a bright, deep orange-yellow, very showy and attractive. Flesh deep golden yellow, much richer in color than Hubbard, fine grained, cooks very dry, and is of excellent flavor. Its keeping qualities are fully equal to, while in productiveness it far excells the Green variety.

MAMMOTH SUMMRㅛ CROOKNECK. This strain is a great improvement on the old variety of Crookneck. It is larger and better in every way.

FORDHOOK. One of the earliest winter squashes, a good yielder, an excellent keeper ano of the best quality. Bug and borer proof.
DEITCATA, Orange-vellow, splashed and striped with very dark green. The quality is rich and dry, wonderfully solid and heavy. For priv. ate use particularly we can recommend this squash, as it far surpasses in richness of flavor any of the large isorts.

IEAMINOHE CEIII. A very large growing squash, often attaining the enormous weight of 250 pounds. Excellent for culinary purposes, and especially desirable for stock.

IRAIIAN (Cocozelle di Fayoli). Vines produce large, much elongated fruits, dark green at first but as they mature becoming marbled with yellow and lighter green in stripes. Fruits in best condition for the table when six to eight inches long, but ean be used when much larger. The young and tender fruits when sliced and fried in oil constitute a vegetable delicacy very popular, especially in Naples.

\section{POPULAR VARIETIES}

Marblehead, Boston Marrow, Yellow Bush Scalloped.

\section{RHUBARB}

Rhabarber. Rhubarbe.

COITORz-Sow in April in drills one foot apart, thinning out to about the same distance apart in the rows when a few inches high. Transplanting into deep rich soll in fall or the following spring, about three feet apart each way.

VICTORIA. Very large, later than Linnaeus.

RHUBARB ROOTs (Cholce Selected). Any of the above named varleties with three or four eyes. 


\section{PUMPIIN}

Kuerbis. Potiron.

CUImUzF-Plant in hills, in well prepared ground, mixing two or three shovelsful of well. rotted manure in each hill. Light soils are best suited for their growth. Plant six to eight seeds in each hill and thin out to three or four after they have made partial growth.

LARGE CHEESE. Cheese shaped; in flavor like Crookneck Squash; yellow fleshed; fine grained and very productive. Superior to most field var1eties.

CONNECMTCUT TIEID. A large yellow variety. hard shell. An excellent variety for tield culture.

JAPANESE PIE. This remarkable variety comes from Javan, and makes a valuable addition to our nie and cooking pumplkins. The Hesh is very thick and nearly solid.

BURPEB'S QUARIR PIE. A distinct and valuable variety.

\section{TURNIP}

Weisse Rueben. Navet.

CUITURE-Light, well manured soil is best suited for turnips. Sow the earliest varieties in April, in drills about fifteen inches apart, an thin out to from 6 to 9 inches in the rows. For a succession sow at intervals until the en d of August.

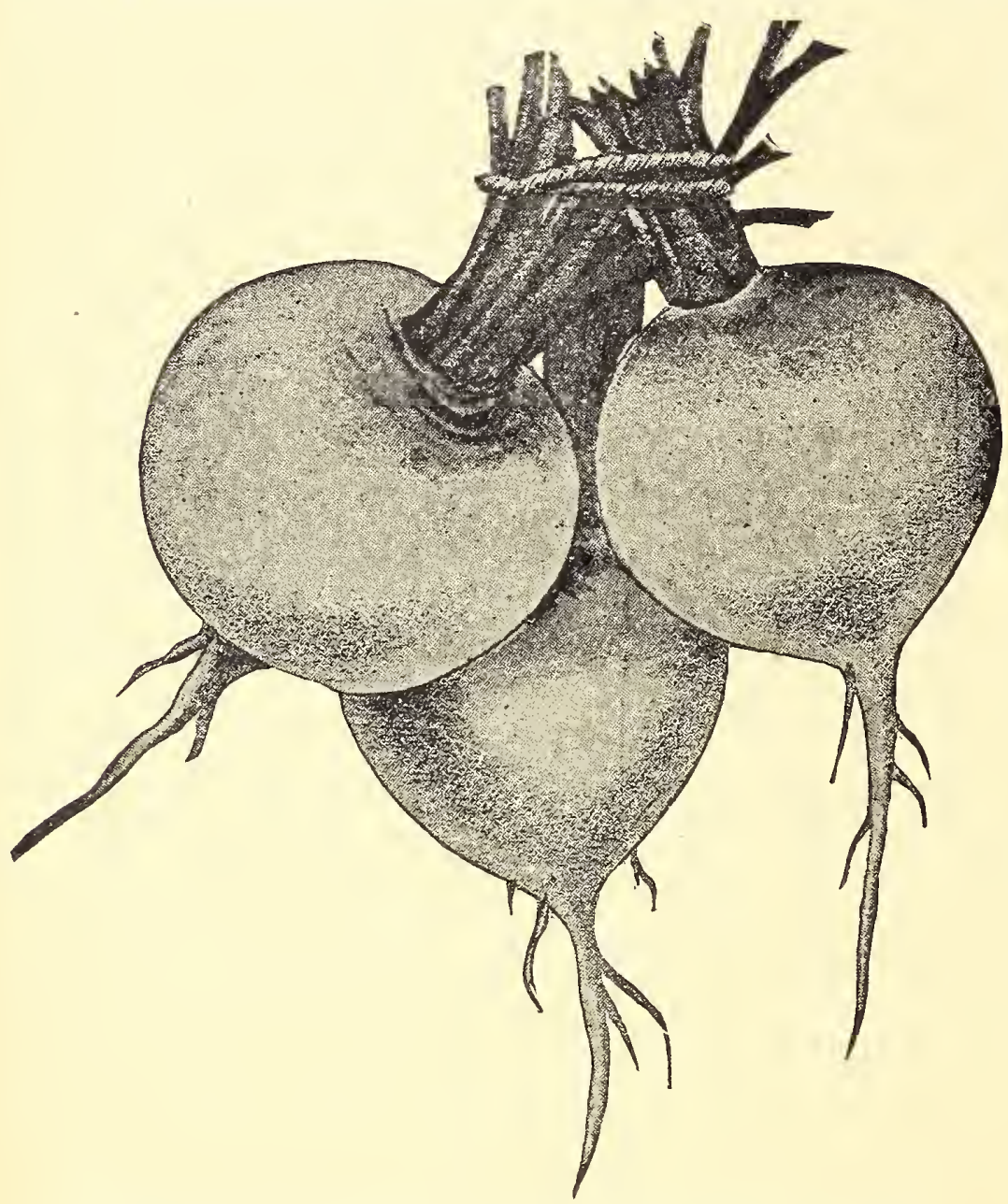

PURPI

TOP WEITE GIOBE. Handsome globular shape, fine grained, tender and sweet the best table turnip and a splendid keeper; a rapid grower and a heavy yielder, producing enormous crops. Our stock has been speclally selected for yeans and cannot be equalled.

IARGE WIITE GLOBE. One of the most productive. In rich soil the roots will frequently grow to 12 pounds in weight. Globe-shaped, skin white and smooth.

GOIDEN BAII (ROBERTSON). A rapld grower; globe-shaped, and of a beautiful color and a good keeper.

PURPLE TOP YELLOW ABERDEEN. A modIum sized, round, late maturing, long keeping, yellow fleshed turnip. Roots yellow with pur: ple top. Flesh pale yellow and of very firm texture, approaching the Rutabaga in this rogard, but tender and sweet. Since it requires a longer time to mature, the seed should be sown about two weeks earlier than most sorts. It is hardy, productive and valuable for stock foeding.

LARGE AMBER GLOBE. One of the best yellow fleshed varieties, grown usually for stock feeding. The roots are of large size and of globular shape. The skin is clear yellow, except the top which is tinged with green. The flesh is light yellow, fine grained and sweet. Tho variety keeps well and is a good cropper.

\section{RUTABAGA}

TURNIP, PURPLE TOP WHITE GLOBE.

FITRA BARIY WHITI MIIAN. Extra-early, cender and delicately flavored; the bulb is of medium size, very handsome, smooth and of a clear ivory-white, both inside and out.

FXTRA EARIY PURPE TOP MIIAIT. FUIIy a week earlier than the Munich, which has heretolore been considered the very earliest. It is of medium size and flat-shaped, pure white flesh, of excellent flavor, very small top and a good keeper.

PURPIF OF FTD TOP STRAP IFAF. Flat; ine flavor and one of the most popular varieties grown. and when sown late is one of our best varieties, being an excellent keeper.

SNOUBALI. A fine-looking. pure white variety which matures in from six to seven weeks. The bulbs have a smooth white skin and are nearly round. This turnip does not grow large, but is very tender and sweet.
CUITURE-The roots may be preserved in a pit or cellar during the winter, and are excellent for table use. Sow from the tenth of June to the middle of July in drills two feet apart and thin out to eight inches.

IMPROVED AMERICAN PURPIE TOP. This is a selected strain of the finest yellow-fleshed rutabaga, suitable either for table use or stock; flesh remariably fine-grained and of a sweet fiavor; the bulb grows clean and smooth, with 8 small top; an immense yielder.

FURST'S MONARCF IRUTABAGA. Distinct in type, being of tankard shape. On account of the size it attains it will yield from two to seven tons more to the acre than any other variety.

BANGHOLM. Oblong in shape with very small neck. The flesh is yellow with dark purple top. Awarded certificate by Danish government as the best yielding rutabaga. 


\section{TOMATO}

Cormori-Sow in early March, in hot-beds or seed-boxes, and when plants have four leaves transplant to four or five inches apart; give plenty of air and endeavor to secure a vigorous and healthy growth. When all danger of frost is past, transplant to open ground, four to six feet apart each way.

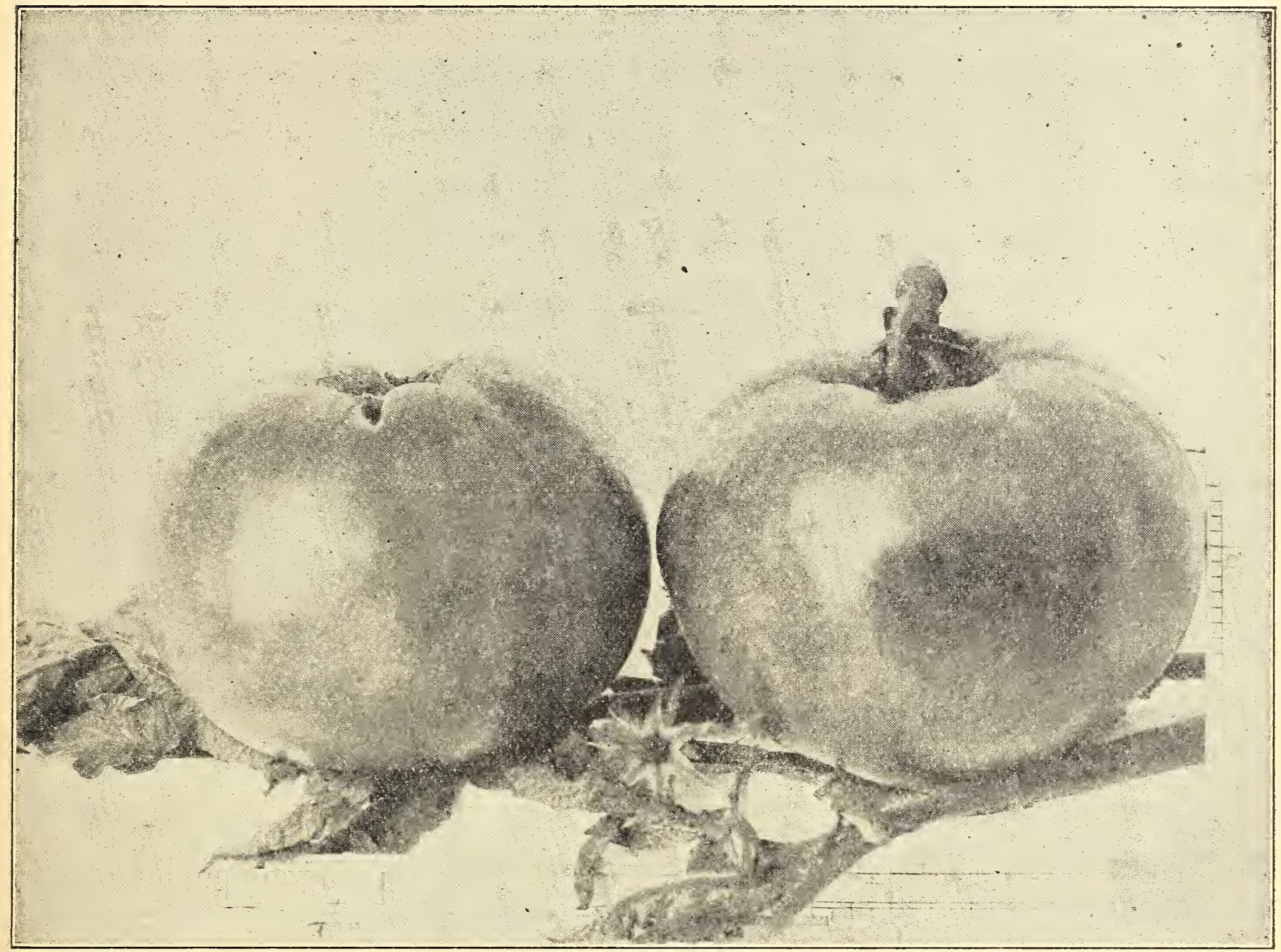

EARLIANA.

DARIIANA. The earliest large smooth rei tomato. This tomato is not only remarkable for Its earliness, but for its very large size, hand. some shape and bright red color. Its solidity and fine quality are quite equal to the best medium and late sorts. One of our growers has a speci. men plant that had by actual count forty-five ripened fruits at time of the first picking, and thirty-five green ones of good size. No marke? gardener should be without this tomato.

DWARE CEAMPION. A great favorite; 1 : dwarf habit and upright, tree-like growth permi close planting; resembles the Acme and is harc to beat for home use. Color, purplish-pink smooth and symetrical; fine quality and solic meated. This is the kind gardeners should grop who sell tomato plants; its stalky, tree-like growth makes most salable plants, outselline other kinds of lanky, scraggily growth.

NIW STONE. Positively the best all round main crop Tomato whether for the market, for canning purposes or for the home garden. The fruit is large, smooth, solld, firm-fleshed, of a handsome deep red color and ripens evenly to the stem without a crack. Our stock of this splendid variety is far superior to what is usually sold under this name.

NEW EARIY DETROIT. Largest and best of the early purplish pink tomatoes. The vines are very vigorous and productive. The fruit is very smooth, not liable to crack, runs uniform in size and is of excellent quality. While one of the newest tomatoes it has proven itself to be one of the best varieties for shipping yet produced.

JOHN BAER. An extra early scarlet fruited variety of superior merit. The vines are very hardy and exceptionally productive. The fruits are the largest of the extra early sorts and are also most attractive in color. They are nearly round, smooth, firm and of excellent quality. It is one of the very earliest to ripen its first fruits and it continues to furnish marketable fruits much longer than other very early varieties. It is an invaluable sort for market gardeners' use. 


\section{TOMATO---Continued}

LIUITCSTOIN'S BEAUTY. Originated with the late Mr. A. W. Livingston, of Franklin County, Ohio, and is one of the best ever introduced. Its size, beauty, shape, color, flavor, durability and productiveness make it desirable to growers.

DWARF STONE. This tomato was origInated b. "Livingston," the tomato specialist. IX habit of vine it resembles Dwarf Champion, bu is of stronger growth, and stands more erect The tomatoes resemble the original Stone in colot shape, and what is remarkable for an erect sort they are practically the same size. The shap is perfect, with good skin, very solid flesh, ripers evenly and is of excellent flavor.

GOIDEIT QUTEN. This is the only first-class large, pure yellow tomato.

POIIIFIOSA. The fruits often weigh two o? three pounds each: of $a$ rich, bright crimson color and all solid meat; exceptionally free from seeds. Extremely delicious in flavor, whether used raw or cooked; a single tomato is enough for a meal. Very desirable for family and market purposes.

ACMIE. One of the earliest and handsomest varieties. The fruit is of medium size, perfectly smooth and regular in shape; very solid and 2 great bearer; color dark red with a purplish tint.

\section{POPULAR VARIETIES}

Livingston's Favorite, Livingston's Perfeco tion, Tropiny, June Pink.

\section{SMALI-FRUITED SORTS}

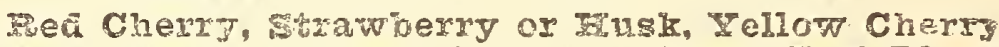
Yellow Pear, Tellow Plum, Red Pear, Red Plum.

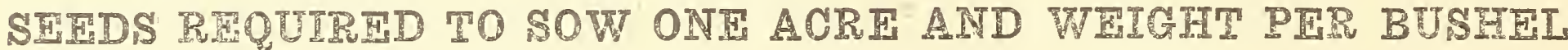

\section{Weight Weight To. Sow Fer. Bu. An Acre}

Alfalfa or Lucerne

Alsvke Clover

Blue Grass Brome Grass (Bromus)

Beans in Hills 20 to 25

Beans in Drills

Broom Corn

Buckwheat $\quad 30$ to 60 ،

Barley _..._._._._._._._. 95 to 110 “"

Clover, Red

Clover Thite

Cow Peas, Broadcast___- 60

Cow Peas, in drills

Cane, Broadcast

Corn Field, in Yills

Corn, Field in Drills

Corn, Field, Broadcast_-_-175

Corn, Pop, shelled

Corn. Sweet, Drills

Corn, Sweet. Broadcast--- 150

Clover, Crimson or Scarlet 10 to 15

English Blue Grass or

Meadow Fescue _-_._-_-_-30 to 40

Flax Seed

Lawn Grass

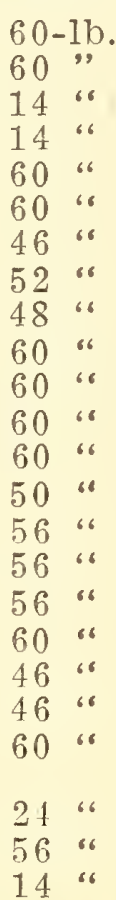

Weight Weight
Tro Sow Per Bu An Acre

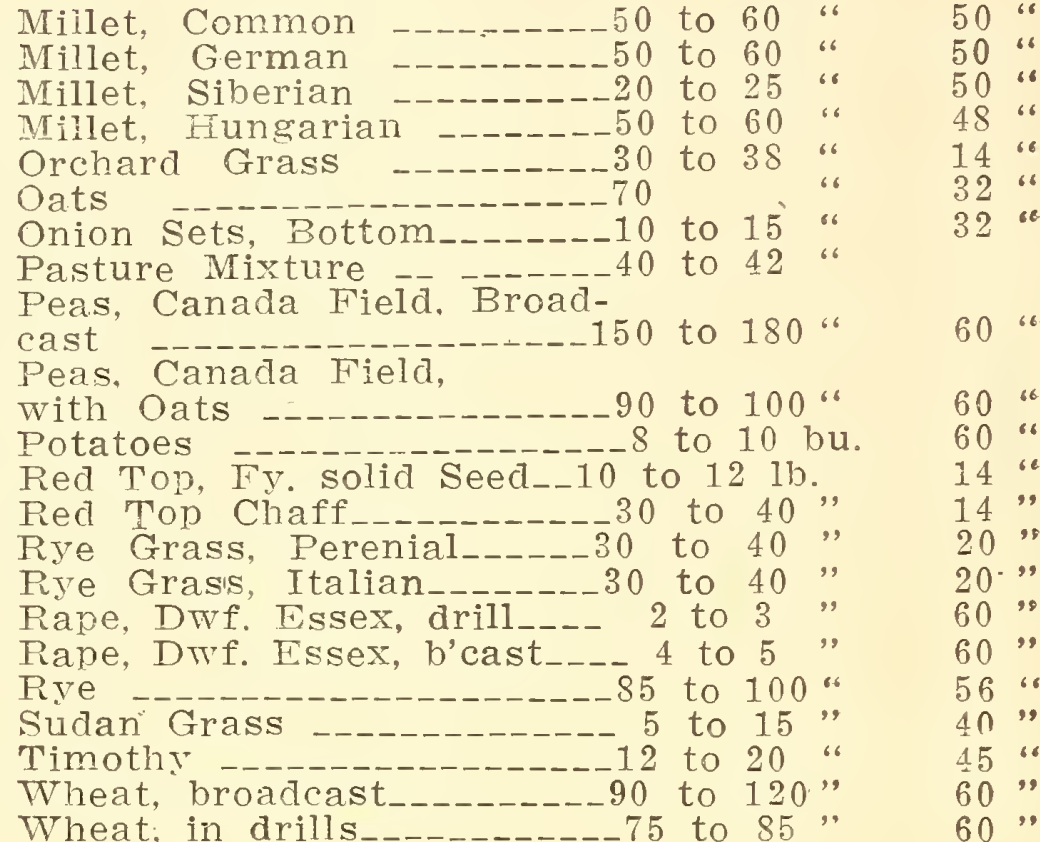

\section{Sowing Table for the Carden}

Artichoke

1 oz. to 500 plants Asparagus --_-1 oz. to $60 \mathrm{ft}$. of drill. 500 plants Beans, Dwarf__-_____-1 1b. to $50 \mathrm{ft}$. of drill Beans. Tall____._. 1 lb. to 75 hills Beets_._-_____-_ oz. to $50 \mathrm{ft}$. of drill Broccoli___________-_1 oz. to 2,000 plants Bruissels Sprouts___-___-_-1 oz. to 2,000 plants Cabbage_____._._-__-_-_ oz. to 2,000 plants Carrot__._______-_ oz. to $150 \mathrm{ft}$. of drill Cauliflower._-_____- 1 oz. to 2,000 plants Celery _._._._._. 1 oz. to 5,000 plants Chicory_._._._._._-_ oz. to $100 \mathrm{ft}$. of drill Corn. Cress Cucumber Egg Plant_............... 1 oz. to 2,000 plants

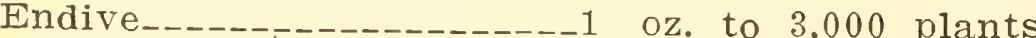
Kale_._._. Kohl Rabi__._._._._. 1 oz. to 2,000 plants Leek
Lettuce 1 oz. to 5,000 plants Melon, Water._._._._._...1 oz. to 30 hills Melon, Musk__._. Okra________._._. 1 oz. to $50 \mathrm{ft}$ of drill Onion Seed_._. Onion, Top Sets._._-_-_- 1 1b. to $60 \mathrm{ft}$. of row Onion, Bottom Sets__-__-_-1 lb. to $755 \mathrm{ft}$. row Parsnip____________. $1 \mathrm{lb}$. to $100 \mathrm{ft}$. of drill

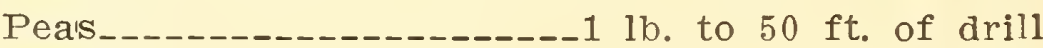

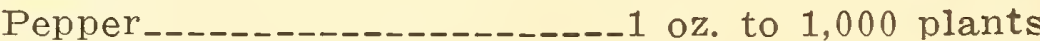

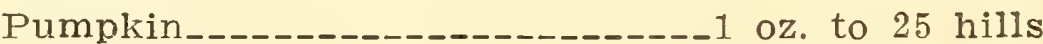
Radish_________-_-_ oz. to $50 \mathrm{ft}$. of drill Salsify__._._._._._._. $1 \mathrm{oz}$. to $50 \mathrm{ft}$. of drill Sage Spinach_________-_1 oz. to $50 \mathrm{ft}$. of drill Squash, Early__-__-__-_-_-_-1 oz. to 50 hills Squash Winter.--_.-_on. to 15 hills Tomato_-_._-_ oz. to 3,000 plants Tobacco_-__-_-_-_ oz. to 10,000 plants Turnip, Early___-__-_-_-_ oz. to $75 \mathrm{ft}$. of drill Turnip, Rutabaga_______-1 oz. to 100 ft. ofdrill 


\section{SELECTED LIST OF FLOWER SEEDS}

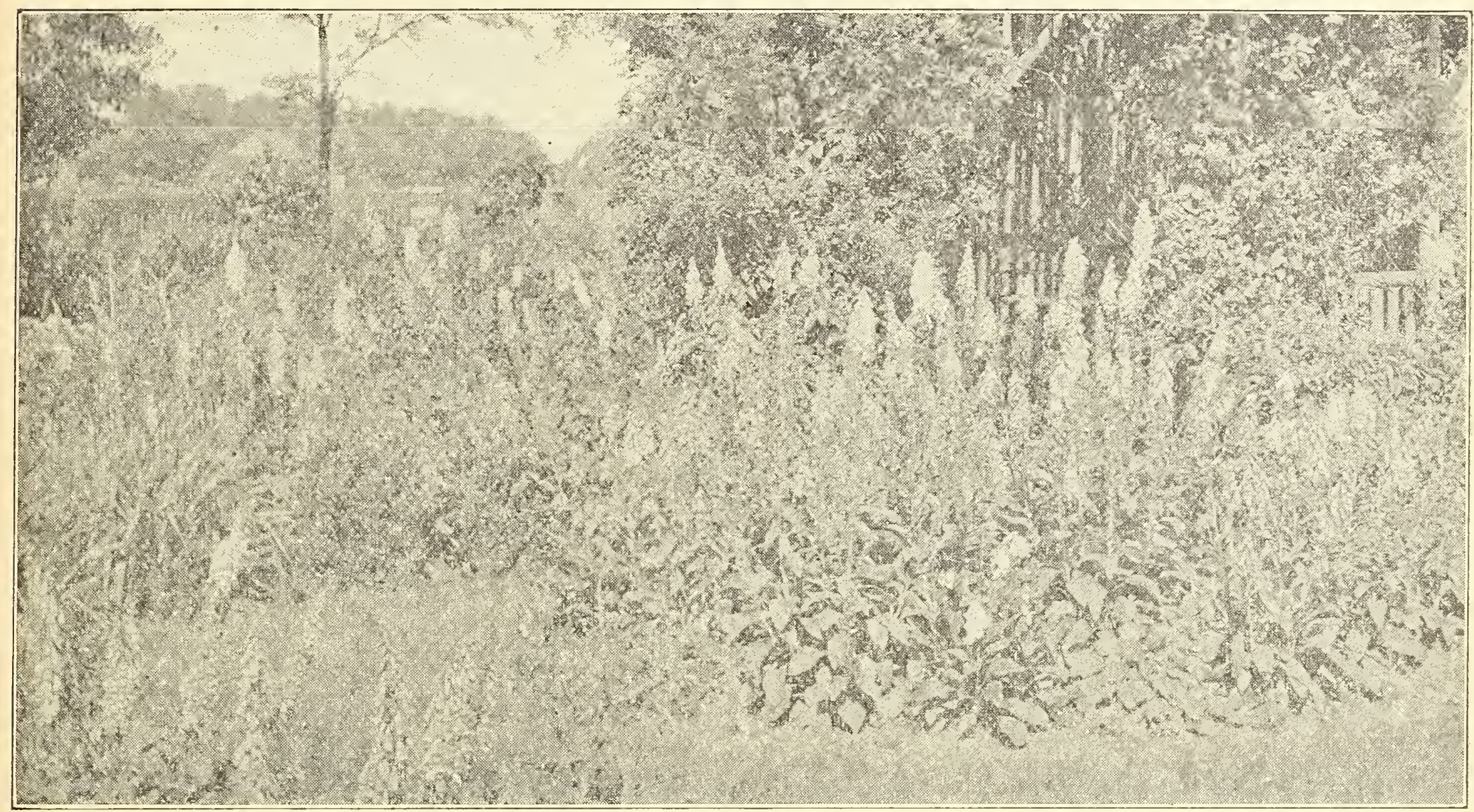

A common mistake in sowing flower, as well as other seeds, is covering too deeply As a general rule, cover only to the depth of the thickness of the seeds; or, with medium-sized seeds, like Balsams, Zinnias, etc., half an inch or so is none too much. Such fine seeds as Portulacas need only to be pressed into the soil with a piece of board or the palm of the hand. Always press the earth down firmly after sowing all flower seeds, else there is danger of their drying before the roots can get firm hold of the soil. Seeds of the hardier Annuals may be sown where they are to grow; but, as a rule, it is preferable to transplant, as the plants are generally stronger and stand the drought better. During very ary weather, and when the seedlings are first set out, they should be watered frequently. Provide some support for all such Annuals as require it.

The weeds should be kept down and the ground loosened often, so that the plants will receive the full benefit of the rains and dews, which they will not if the ground is allowed to become hard and baked.

\section{ASTER}

(HAlf-hardy Annual) One of the best Annuals for cut-finvers

The Aster is of easy culture and very popular. Plants from seed sown in the open ground in May bloom finely in September and October. For July and August flowers, sow in March or April in cold frame, spent hotbed, or in pots or boxes in the house. Cover the seeds about half an inch deep with rich, light soil, and, when the plants have three or four leaves, transplant about 18 inches apart each way into well-prepared beds. Manures too fresh or used in too large quantities sometimes induce disease in Asters. When used, they should be thoroughly well decayed and mixed with the soil. Small quantities of slaked lime or fresh wood-ashes stirred into the surface of the Aster beds form good tonics for the plants and keep disease and insects from the roots.

COMET-Giant. Very large flowers.

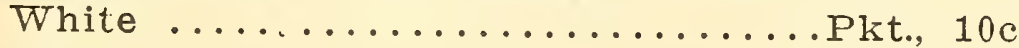

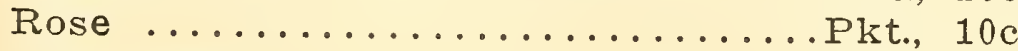

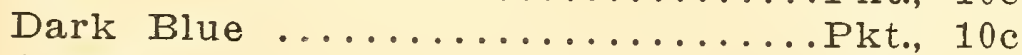

Crimson ........................ 10c

DOUBLE QUILLED. Very free bloomers.

Mixed Colors ........................ 10c

VICTORIA-Tall. Large flowers, imbricated petals.

White ............................ 10c

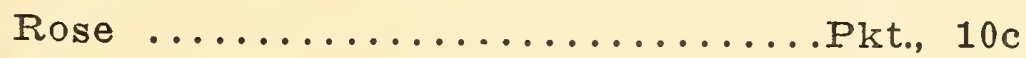

Dark Scarlet......................... 10c

Dark Blue ........................ 10c
CREGO Immense Flowers.

Mixed Colors ......................... 10c

PRANCHING. Forms large bushes.

White ...................... 10c

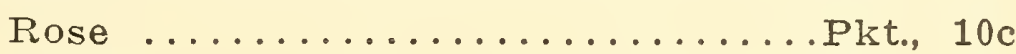

Purple ............................ $10 \mathrm{c}$

Crimson .................. Pkt., $10 c$ Mixed .....1/4 oz., 40c; 1 oz., $\$ 1.25$; Pkt., $10 \mathrm{c}$

Extra Choice Mixture of All the Above, $1 / 4$ oz., 40c; 1 oz., \$1.25; Pkt., 10c.

Fine Mixture, $1 / 4$ oz., 35c; 1 oz., $\$ 1.00$; per pkt. 


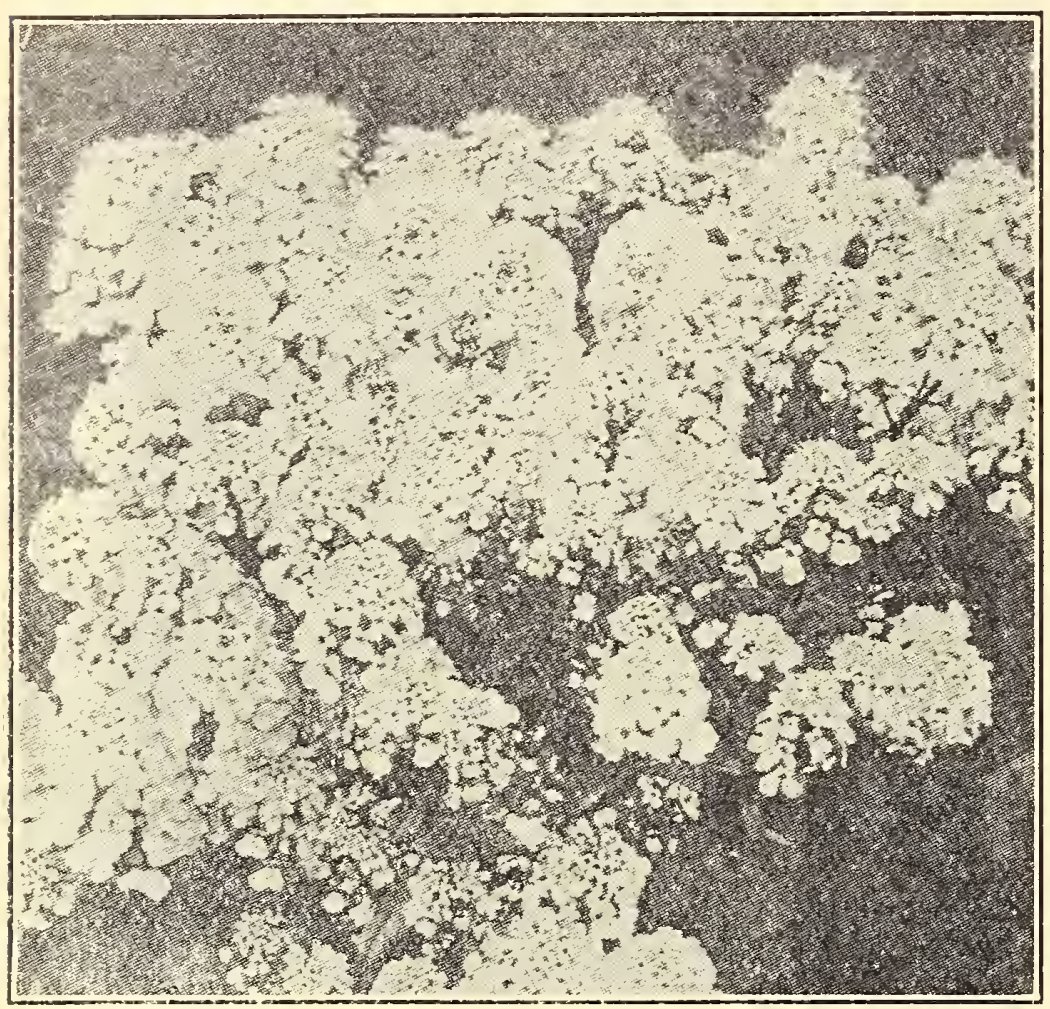

ALYSSUM, LITTLE GEM

\section{AGERATUM}

MFXICANUM (Blue). Easily started from seed, grows well gimost anywhere and bloom: profusely throughout the season. Pkt., 5c.

\section{BALSAMS-LADY SLIPPERS}

COITURE-Sow in the open ground in May. Transplanting two or three times has a tendency to dwarf the plants into better shape, and is advantageous. Give them plenty of room, as they easily cover 12 to 18 inches of space each way.

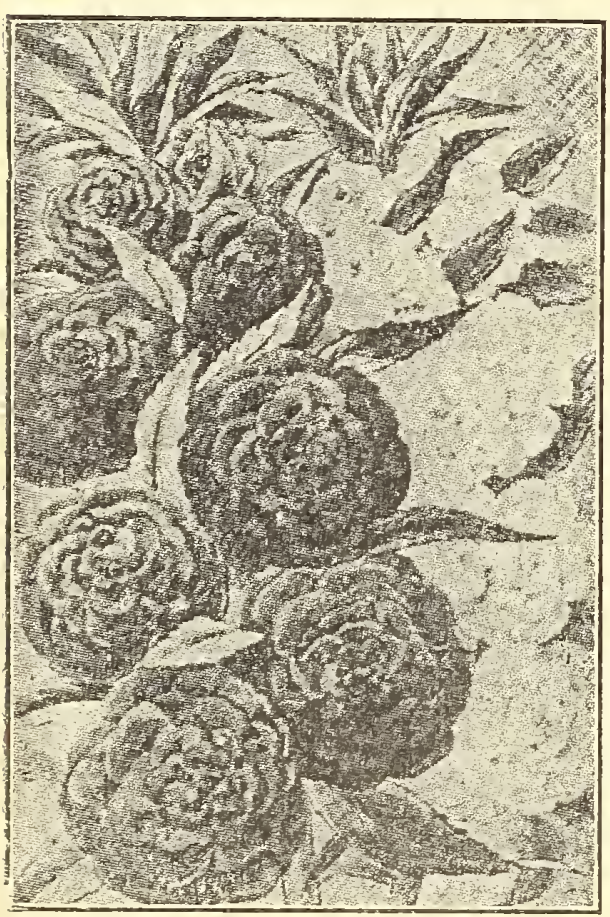

SITOW W EITI. ery double, perfect form. Pkt., $5 \mathrm{c}$.

CRIMSOW. C o nrast $s$ beautifully with above. Pkt. $5 \mathrm{c}$.

DOUBI표 MIERD. All colors. Pkt., 5c.

\section{DOUBIE CAMPI-} IIA PIOWIRED. A fine strain of very double flowers of exyuisite shades. Pkt.

I IVIN CIBID MIXTURE. The fin est mixture in cultivation. The flowers are evry large, measuring from 2 to 3 inches in dlameter, of perfect form, resembling the flower of the Camellia, and are as double. The coiors of the flowers are varied and brilliant, comprising pure white, crimson, white shaded lilac, rose, spotted, scarlet, blue, purple and many other tints. Pkt., $5 \mathrm{c}$.

LANCEOLATA GRANDIFLORA. A very hardy perennial, blooming the first year and producing on long stems a succession of rich bright yellow flowers two to three inches across. Very valuable for cutting. Seed may also be sown in fall outdoors. About two feet high. Pkt., 10c.

\section{BALSAM APPLE AND}

\section{PEAR}

Very curlous; rapid and dense climbers, with

ornamental foliage and golden yellow fruit, which opens when ripe, showing the seed and blood-red inside.

BALSAM APPLE. Orange fruits. Pkt., 5c.

BALSAM PEAR. Coppery scarlet. Pkt., 5c.

\section{ALYSSUM}

IITIIF GEM. A dainty pragrant little flower much used for borders, ribbons, edging, rockwork and baskets and window boxes. Should be sown thickly and the seedlings thinned out to proper distance. Pkt., 5c; 1/4 oz., 15c; 0z., 50c.

SWIET AIYSSUM. Fragrant flowers, taller than little Gem. Pkt., 5c; 1/4 oz., 10c; oz., 30c.

\section{ANTIRRHINUM-SNAP- DRAGON}

Snapdragon is one of our finest perennials. If planted early will flower the first year as an annual. Sow seed in the open ground, trans. planting to 1 foot apart each way. They will bloom in July and August.

LARGE FLOWERING TALL. Mixed, pkt., Бc.

\section{AMARANTHUS}

CAUDATUS, IOVE-IIES BIEFDING. A very ornamental foliage plant. Pkt., 5c.

TRICOIOR, JOSEPE'S COAT, 2 feet high. Pkt., 5c.

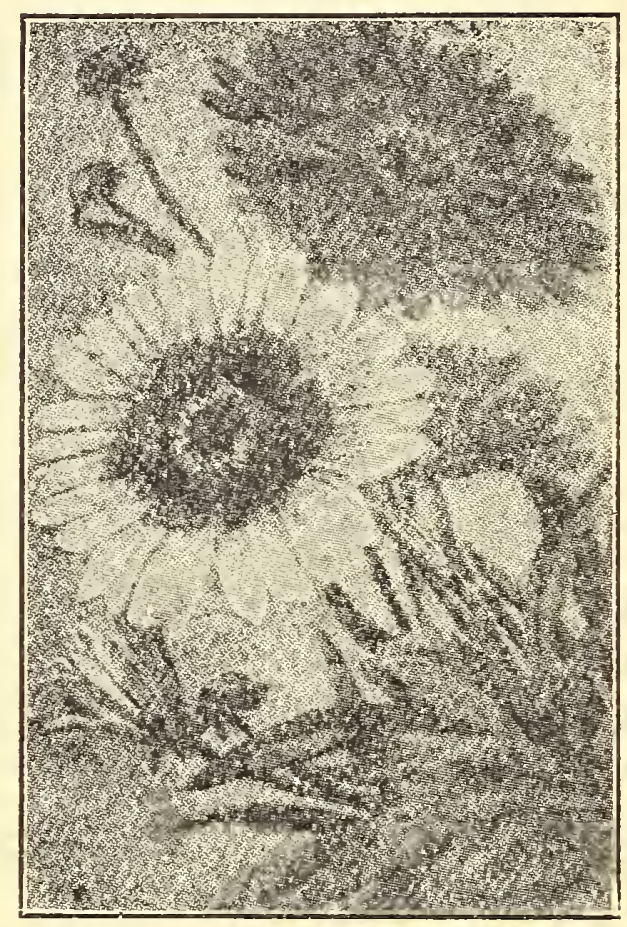

CALLIOPSIS

\section{CATTIOPEI:}

Very showy; freob l o o m ing plants. Flowers yellow, with centers of rich rea maroons and browns. Sow in open ground in spring and thin. giving plants plenty of room. Finest mixed colors. Pkt $5 \mathrm{c}$.

\section{CARNATIONS}

\section{W $\mathrm{E}$ F MAB}

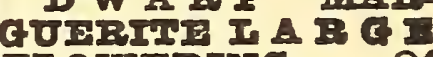
FIOW ERING. Of vigorous growth, especially adapted for outdoor culture These are the most abundant bloomers of all the Carnation Pinks. The flowers are of brilliant coiors, ranging through many beautiful shades of red, pink, white, varlegated, etc.; they are of perfect form and large size. Those grown in spring commence flowering in early summer, and continue to bloom in lavish profusion until checked by frost. Pkt., 10c.

\section{CASTOR BEANS}

Tall, majestic plants for lawn, with leaves or rlossy green, brown or bronzed metallic hue, and long spilkes of scarlet and green prickly fruit. Of very quick growth in rich soll. Tender annual, 6 to 15 feet high.

GIANT ZANZIBAR. A new form of Ricinus; of short-jointed, stout growth and extraordinarily large leaves, which are produced in such aboundance that the plant is a perfect pyramid of beautiful follage. The most tropical and ornamental Castor Beari yet introduced. Pkt., $5 \mathrm{c}$.

SANGUINENS. Red follage and 6 to 8 feet tall, very strong. Pkt., 5c; oz., $35 \mathrm{c}$.

CASTOR BEANS, MANY SORTS MIXED. PKt. Sc; 1 oz., $30 \mathrm{c}$. 


\section{CYPRESS VINE}

A summer climbing annual with fine feathory foliage and pretty star-shaped flowers.

Mixed Colors

\section{CANNAS}

Cannas will bloom the first year if the seed is soaked in warm water for 24 hours after cutting off about one-sixteenth of an inch from one of the ends. Sow indoors in January or February and they will flower in June.

CROZY'S DWA A IARGE FIOWERIRG FBENCE. In this new class of Cannas the foliage is luxuriant and the plants dwarf in habit. Their great merit, however, lies in the large size and brilliant hues of the flowers, ranging through all shades of yellow and orange to the richest crimson, scarlet and vermillion: some are also beautifully spotted. Mixed. Pkt., 5c.

CANDYTUF'. The Candytufts are among the best flowers for edging, bedding, massing or rockeries, and for cutting. Several of the varleties are fragrant, and all are profuse in bloom. Sow out doors in April, and thin well when the plants grow about an inch. Sow again in a month, and late in July for fall flowers. Give rich soil and water freely.

Empress white, 1 ft......1/4 oz., 20c; pkt., 10c Lilacinia, Lilac, 1 ft........1/4 oz., 25c; pkt., 10c Mixed choice colors.......1/4 oz., 10c; pkt., $5 \mathrm{c}$

\section{CENTAUREA}

BACERIOB'S BUTTON. Also known as Corn Flower, Blue Bottle, etc. If the seed is sown just as soon as the ground is fit in spring, will furnish a profusion of white, blue and pink fiowers from July until late in autumn. Hardy annual. Two or three feet high. Mixed, pkt., 5c.

GIMMOCARPA (Dusty miller). Planted for bedding, not for flowers. Silver-gray foliage Pkt., 7c.

SWEET SULTAN. Stiffly erect plants, slightly resembling the thistle in growth, with very double, rich yellow, pure white, and mauve flowers. The small petals are finely fringed and flowers are of a delightful fragrance. Of easiest culture, blooming profusely in cool locations. Pkt., $5 \mathrm{c}$.

\section{COBAEA SCANDENS}

\section{CATHEDRAL BELLS}

PURPLE. $\quad 30 \mathrm{ft}$. One of the handsomest and most rapid growing climbers. The flowers are bell. shaped and of a purplish-lilac when full grown. It is a very prolific bloomer and vigorous in vines and flowers. It is very free from insect pests. Pkt., 5c.

\section{CELOSIA}

CRISTATA, CoCksconb. Annual plants of tropical origin. One of the most satisfactory and showy for garden decoration. Fine Mixed. Pkt., 5c.

PLUMosa. Beautiful foliage plants blooming in late summer and autumn, and producing large, showr plumes, curled and curved, very much resembling ostrich feathers. Pkt., 5c.

CHILdsI, Chinese Wool Flower. This is a new species of this popular variety. Very showy flowers, deep scarlet and represent a ball of yarn with open ends. Very striking. Good for cut flowers and easy to raise. Pkt., 10c.

\section{CHRYSANTHEMUM}

Do not confound these annuals with the winter-flowering sorts of the florists. They bloom profusely from early summer until frost, and when grown in large beds or masses, their bright colors make a splendid show. The plants can be brought into bloom early by sowing the seeds in frames or window-boxes, and afterwards transplanting to the gardea; or seed may be sown where the plants are to flower, if the seedlings are thinned to 8 to 10 inches apart. A little pinching back in early growth makes the plants bushy and shapely. All are fine for cut-flowers. Average height, 1 to $11 / 2 \mathrm{ft}$.

Mixed. Yellow, white, etc., pkt., $5 \mathrm{c}$.

CARDINAL CLIMBER. A valuable novelty of recent introduction. It is a rapid grower, soon forming a vine 20 to 30 feet in length, with dark green, deeply cut leaves and bearing quantities of cardinal red flowers. Should be planted in rich soil in warm sunny situation. Best results will be obtained by planting seeds in the house. Per Plit. 15c.

CAMPANULA MEDIUM (Canterbury Bell). This plant is a biennial and seeds should be sown in late spring or early summer and transplanted to their permanent location as soon as strong enough. Protect through winter and fertilize well in spring. Mixed colors. Pkt., $5 \mathrm{c}$.

\section{COLUMBINE-AQUILEGIA}

Hardy perennial, luxuriating in the moister sit uation in the garden, where they form permanent clumps, growing from $1 \frac{1 / 2}{\text { to } 3}$ fet high. The large, unique, long-spurred flowers, gracefully hung on long $s i \geq m s$, are not only brillianty effective on the plar.: but equally as desirable when cut for vase and house decorations. Pkt., $10 \mathrm{c}$.

\section{CUSMOS}

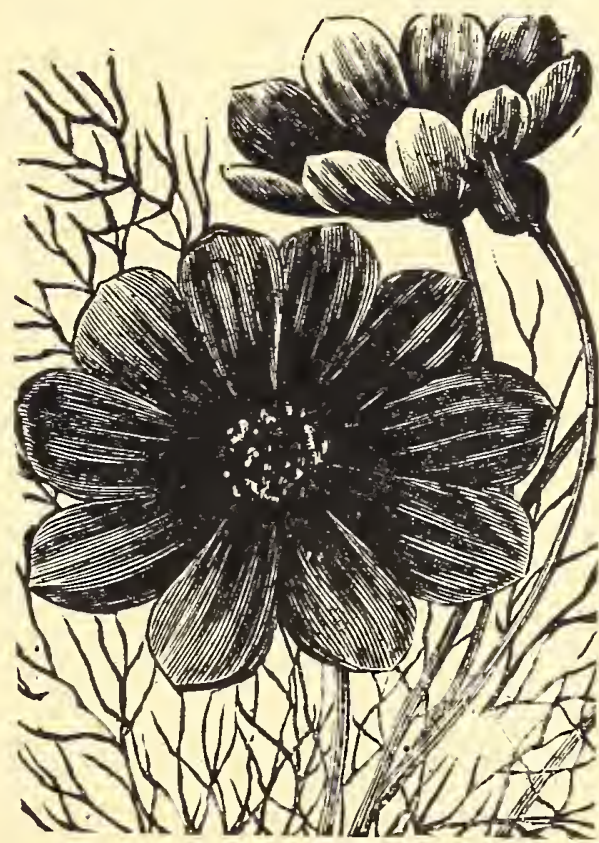

One of the no. table fall fowers. A strong, tall. growing a n i u a with bold flowers of exquisite daintines: ind airness, height ened in effect by $t h$ e ir foliage-setting of feathery green. It is most effective when planted in broad masses, or $10 \mathrm{ng}$ background borders against evergreens or fences. From seed started early in the house or frame, the plants will flower profusely in late June or early July. If topped when hall grown, they will cusius bloom quicker, the check seeming to induce earlier flowering. We offer only the choice. large-flowering strains.

Early Flowering, mixed, oz., 50c; pkt., 5c.

Giant Autumn Filowering, oz., 30c; pkt., 5c.

\section{DAHLIAS}

Although perennial, these will lloom the first year from seer, if sown indoors is boxes during March or April and transplanted, hen danger o? Prost is over.

CEOICE DOUBIE MIXED, Sa ed from the finest varieties in cultivation. Pkt., $5 \mathrm{c}$

CHOICE SINGLE MIXED. Pkt., $5 \mathrm{c}$. 


\section{DAISY - BELLIS PERENNIS}

May be sown in February or March in shallow boxes of light, rich soil, covering the seeds to about three times their own thickness, and pressing soil firmly over them. Keep in a warm window, hotbed or greenhouse. When well out of the seed-leaf transplant to new boxes, and set out in the open ground when danger from frost is past. Or, sow in beds outside in August or September; protect with straw or litter over winter, and transplant to their permanent positions in the spring.

Mixed. Very fine.................pkt., 10c Shasta Daisy. Very large, white...pkt., 10c

\section{ESCHSCHOLTZIA}

(Commonly called Califormia Popp.)

The state flower of California. An annual, very bright and rich in its pure tints of yellow, orange, etc. The plants average about a foot in height, with silvery foliage, and produce their large, poppy-like flowers from early spring until frost. They are most effective when grown in beds of considerable size, over which the seed may be sown broadcast thinly and lightly raked in. These sowings may be made early in spring or late in autumn for earlier germination, blooming the next spring. Useful as a pot-plant and for cut-flowers. Pkt. jc.

\section{DIANTHUS OR PINIKS}

The family of "Pinks" is unrivaled for brilliancy and rich variety of color, blooming profusely until late in the autumn, rendering them one of the most satisfactory of all our annuals for garden decoration. Height about 1 foot.

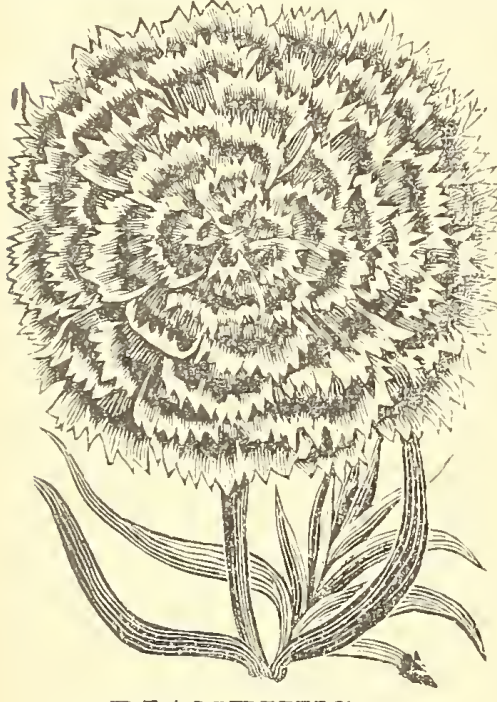

DIANTHUS

HEDDEWIGGII

DOUBI, CEINESE. Large, double fragrant flowers, mixed. Pkt., 5 c

\section{FORGET-ME-NOT MYOSOTIS}

Pretty little favorites with lovely clucters ine, delicate flowers. Blue, $1 / 2$ foot. Pkt., $5 \mathrm{c}$.

\section{EVERLASTING FLOWERS}

These are very popular and desirable for winter decorations, bouquets, wreaths, etc. They should be cut when they come into full bloom, tied into bunches and dried in the shade, with their head. downward.

REODANTHE AIBA. Pure silver white; very beautiful. Pkt., $5 \mathrm{c}$.

RHODANTHE IMACUIATA. Bright rosy crim. son with yellow disc. Plit., 5c.

EEIICIRYSUM. Finest mixed. Large bealit ful, with double white, yellow, scarlet. Pkt., $5 \mathrm{c}$.

\section{FOUR O'CLOCKS}

Also called Marvel of Peru. Handsome, freelowering, sweet scented annuals. Blossoms striped and variegated and of various colors.

CHOICW MIXED. .Pkt., 5c; oz., 20c.

\section{FOX GLOVE - DIGITALIS}

Beautiful hardy perennials of easy culture, bearing long spikes of showy flowers, many beautifully spotted; height 3 to 5 feet.

FINE MIXED. Pkt., 10c.

\section{GERANIUM}

Although perennials, these grow readily from seed and if planted early will produce blooming plants the first year.

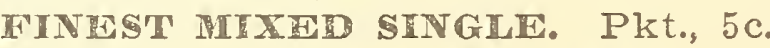

\section{GOURD}

Rapid growing annuals, suitable for covering old stumps, fences, etc. The small ornamental sorts make fine toys for children.

MIXED GOURDS. Pkt., $5 \mathrm{c} ; 1 / 2$ oz., $15 \mathrm{c}$

GYPSOPHILA (Baby's Breath). The feathery plant with little star-shaped flowers used in making up bouquets. Grows easily in every garden; 2-3 feet.

Paniculata. Fine for bouquets; white flowers; perennial. Pkt., $5 \mathrm{c}$

\section{JOR'S TEARS}

Useful as a remedy for sore throat, goitre and teething infants. Pkt., 5c; oz .,15c.

\section{HUMULUS-JAPANESE}

A most rapid growing annual climber covered densely with light-green leaves. Easily grown everywhere and will attain a height of twenty to thirty feet in a single season from seed. Per plit., $7 \mathrm{c}$.

JAPANESE VARIEGATED HOP. (Humulus Japonicus Variegatus.) The leaves are strikingly variegated; the first color is bright deep green, distinctly marked and blotched with silvery white tinged with yellow; now and then a leaf will be almost snowy white, and another one, not far away, almost green. A strong xrower, twenty to thirty feet in a few weeks' time. Fer pkt., 5c.

\section{HELIOTROPE}

Deliciously fragrant flowering plants, 1 to 2 eet bigh. Favorites for pot culture in winter alld bedding in summer.

FINE MIXED. Pkt., $5 \mathrm{c}$.

\section{HIBISCUS}

AFICANUS. One of the most ornamental, watiful and showy plants cultivated. Hardy inuals, cream color, rich brown center. One and one-half efet high. Pkt., $5 \mathrm{c}$.

VEV GIANT FLOWERING MALLOW MARVELS

One of the most striking productions of recent years in hardy plants. They form bushy plants 5 to 6 feet high and 3 to 4 feet across and blossom profusely from July to late Fall. The flowers when well grown are immense in size 6 to 8 inches across-and range in color from crimson through various shades of red and pink to white.

They are perfectly hardy and easily grown succeeding best if planted in a deep rich and moist soil. Price per pkt., 15c. 


\section{HOLLYHOCKS}

MAMMOTH AIIEGHENY. If sown early, blooms the first year from seed. The flowers of this new variety are so different from the old conventional ones that but for the similar habit of the plant it would not be taken for a Hollyhock. They are from 4 to 6 inches in diameter, ranging from semidouble to double, and finely fringed and are shell-pink, rose and ruby red, a shade or two deeper at the center, and exquisitely tinted toward the edge. Plit. 10c; pkts. $25 \mathrm{c}$.

DOUBIF DAR I RFD. Pkt., 10c. DOUBIE WHIT: Pkt., 10c.

DOUBIE PIN Pkt., 15c.

DOUBLI CRIMsoN. Pkt., $10 \mathrm{c}$.

D O UI I YII LoW. Pkt., 10c.

Double Mixed Extra Choice seed saved from exhibition flowers. Pkt., పc.

\section{KOCHIA -SUMMER CYPRESS}

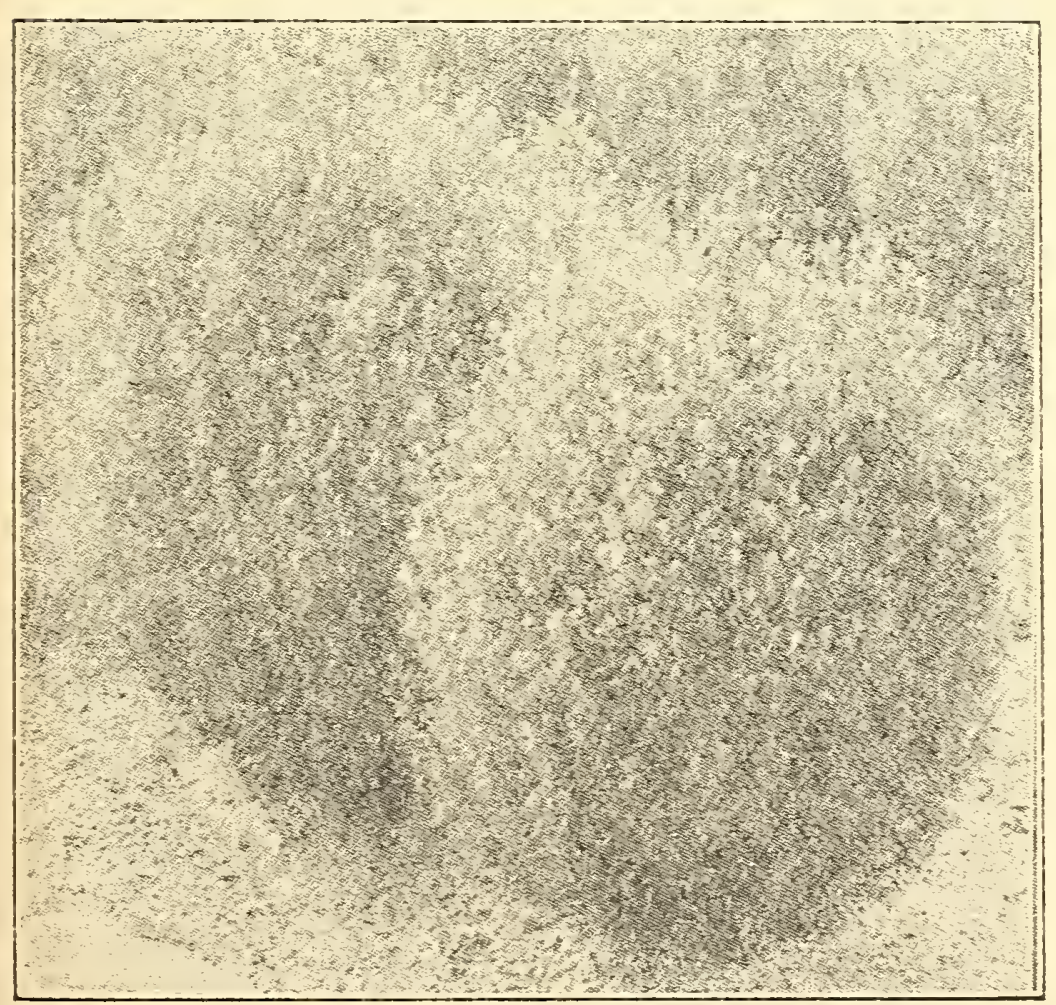

TRICHOPHYIIA. A splendid annul, growing two to two and one-half feet high. The slender-leaved plants are of a cypress-like appearance during summer, changing their light green foliage to carmine and fiery red colorings toward autumn. Forms beautifully decorative bushes on the lawn. Pkt., 5c.

\section{HYACINTH BEAN}

\section{DOLICHOS}

DOLICHOS-(Hyacinth Bean). Of extra rapid growth; makes a dense attractive screen. The New "Darkness" and Darlight" introduced bs us from Japan, are incomparabiy superior to the "Lablab" varieties, previously in cultivation. "DARKNESS." Both stems and under side of leaves purplish red. Numerous long spikes of pea-like flowers, deep redđish violet, followed by beautiful seed-pods; blooms early and free15. Per pkt., 5c; per oz., 20c.

DOLICHOS, "DAYIIGHT," The vines grow quickly to a height to eight to ten feet, and blossom profusely from base to summit, the large spikes of pure white flowers standing out boldly from the rich green foliage. As the flowers drop from the long spikes they are succeoded by broad, velvety, showy white pods which retain their purity and fressness of color a long time. Per pkt., 5c; per oz., 20c.

KUDZU VINE

PUERARIA THUNBERGIANA

A perfectly hardy perennial climber attaining a height of twenty to thirty feet in a season Purple flower. Per pkt., $10 \mathrm{c}$.

\section{MORNING GLORIES}

JAPANESE IMPEPIAI, One great charm of these plants lies in the great variety and infinite charm of its foliage, as well as the size and beauty of the flowers, the latter varying from pure white to rose, crimson and carmine through blues and purples of every shade, being streaked mottled, striped, and bordered in wonderful fashion. The vines are vigorous, growing to $a$, helght of 30 or 40 feet in rich soil. Soak the seed in water 24 hours before sowing. Pkt., $5 \mathrm{c}$; oz., $15 \mathrm{c}$. MAJOR, MIXPD (Common Morning Glory). Pkt., 5c; $0 z_{\text {e, }} 15 \mathrm{c}$.

\section{MARIGOLD}

Well-known annuals. Very free-flowering and of easy culture. The African varieties have large yellow or orange-colored flowers, and are adapted to large beds. The French are dwarfer in growth, with beautiful striped flowers, and are better suited to pot culture.

EIDORADO. Immense flowers, 9 to 14 inches around; double primrose. orange, and golden shades. Pkt., 5c; $1 / 4$ oz., $15 \mathrm{c}$

TALI AFRICAN. Mixed. Pkt., 5c.

DIVARE FRENCH MIXED. Pkt., $5 c$.

\section{MOONFLOWER}

One of the most rapid-growing of all annua] climbing vines. The vines are literally covered with thousands of immense, pure white, fragrant flowers, opening in the evening and remaining open until noon the following day, and if cloudy, all day, many of them measuring over seven inches across. Planted in rich ground, in a sunny situation, and given plenty of water, the vines attain a height of seventy-five feet. Pkt., 10c; $1 / 2$ oz., $25 \mathrm{c}$.

\section{NICOTIANA}

\section{- Sweet Scented Tobacco}

AFIIIS. The popular free-flowering variety; iragrant, star-shaped, white flowers; annual; feet high. Pkt., 10c.

SATDFAE. New. A profuse-flowering an nual of bushy branching growth, 2 feet high, bearing large carmine-rose flowers during summer and fall. Pkt., $10 \mathrm{c}$. 


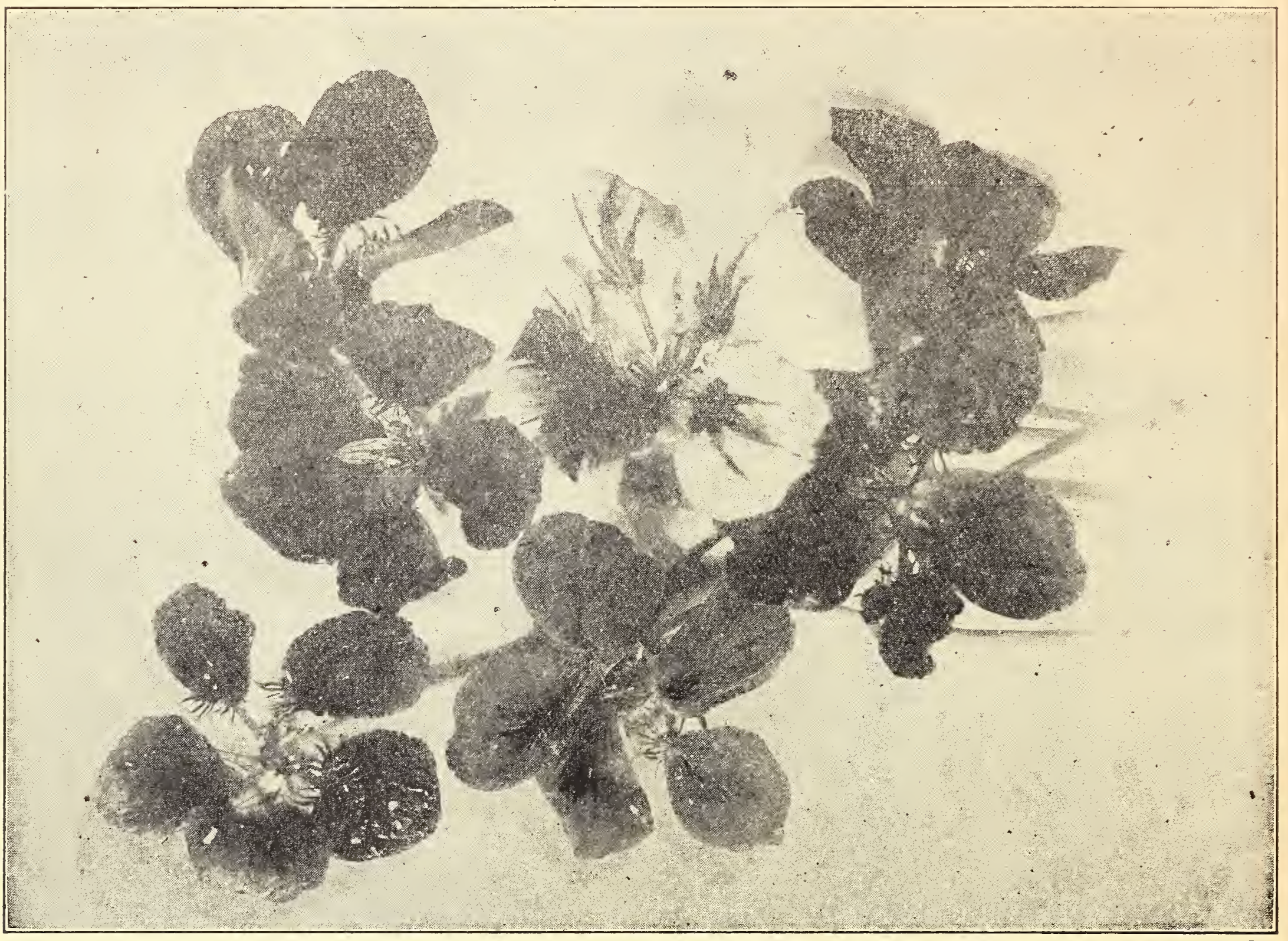

\section{NASTURTIUM}

A marvelous range of new colors has been developed in this favorite flower, which for three or four months of the season makes a better display than almost any other plant. No other annual will produce such a lavish profusion of flowers for so long a time with the same small outlay of time and labor. The maximum of bloom is produced in thin soils, and never flags through the hottest weather. In soils too rich leaves predominate and the plants are apt to rot off in wet weather, especialiy is standing too close.

\section{DWARF, or TOM THUMB}

EMPRESS OF IFDIA. Intense scarlet. Pkt. $7 \mathrm{c} ;$ oz., $20 \mathrm{c}$.

PEARL. Creamy white. Pkt., 5c; oz., 20c. RUBY KING. Dark red. Pkt., 5c; oz., 20c.

GOLDEN KING. Bright yellow. Pkt., 5c; oz., $20 \mathrm{c}$.

ROSE. Pkt., 5c; oz., 20c.

FXTRA CHOICE MIXIP. This mixture is composed of the choicest large-flowering named varieties and grown both in mixture and separate strains properly blended. Pkt., 5c; oz., 10c; $1 / 4$ lb., $35 \mathrm{c}$; $1 \mathrm{~b}$., $\$ 1.25$.

VARIEGATED-LEAVED. Every leaf is varie. gated with white, green and yellow, but each different from the other. The flowers are large and full and of various colors. Pkt., 10c.

\section{LOBB'S CLIMBING}

MADAME GUNTHER HYBRIDS. A French strain noted for wide range of colors. Pkt., $5 \mathrm{c}$. oz. $20 \mathrm{c}$.

DARK CRTMSON. Pkt..5c; oz., 15c.

PEARL-(Moonlight). Whitish. Pkt. 5c; oz. 15c

YELLOW-(Luteum). Pkt., $5 \mathrm{c}$; oz., $15 \mathrm{c}$.

VESUVIUS. ' Salmon; dark leaved. Pkt., 5c; oz. $15 \mathrm{c}$.

FINE MIXED. Pkt., 5c; oz., 10c; $1 / 4$ lb., 35c; lb., 1.25 .

CÁNARIENSIS. Yellow flower. Pkt., 5c; Canary Bird Flower.)

\section{LARKSPUR-DELPHINIUM}

Verv elegant and ornamental plants, producing in great variety of form and color some of the most beautiful flowers in cultivation.
DOUBIF DWARF ROCKFT, MIXFD COTOBS.

Pkt.o 5c.

TALL DOUBLE STOCK FLOWERED. The finest variety splendid spihes of double flowers. Pkt., 10c.

\section{LOBELIA}

Dwarf-growing plants, with blue, white, crimson and rose flowers, adapted for ribbon borders and for vases or hanging baskets.

FINED MIXED. Pkt. $5 \mathrm{c}$

CRYSTAL PALACE COMPACTA. A rich deep blue with dark foliage. The finest dark blue variety for bedding. Pkt., $10 \mathrm{c}$.

\section{PHLOX DRUMMONDI-Grandiflora}

The annual varieties should be sown in masses or ribbon beds. They are very easily grown from seed, giving a brilliant display of color. Sow as soon as the frost is out of the ground in the spring and for later blooming in May. For beds and massing nothing can surpass these beautiful annuals. They produce immense trusses of large, brilliant flowers of numberless hues throughout the summer. Hardy annual; 11/ feet ALBA. Pure white. Pkt., 10c.

COCCINEA. Brilliant scarlet. Pkt., 10c.

ISABELLINA. Yellow. Pkt., $10 \mathrm{c}$.

EXTRA CBOICE. Contains the above and many other excellent large flowering sorts. Pkt $10 \mathrm{c}$

STARRID AND FRINGED. These are the most distinct and striking Phlox we have. The flowers have a most distinct and starlike appearance, their attractiveness being greatly enhanced by the broad. white margins whlch border the edges of the petals. Pkt., $10 \mathrm{c}$. 


\section{PANSY (Viola tricolor. Heartease.)}
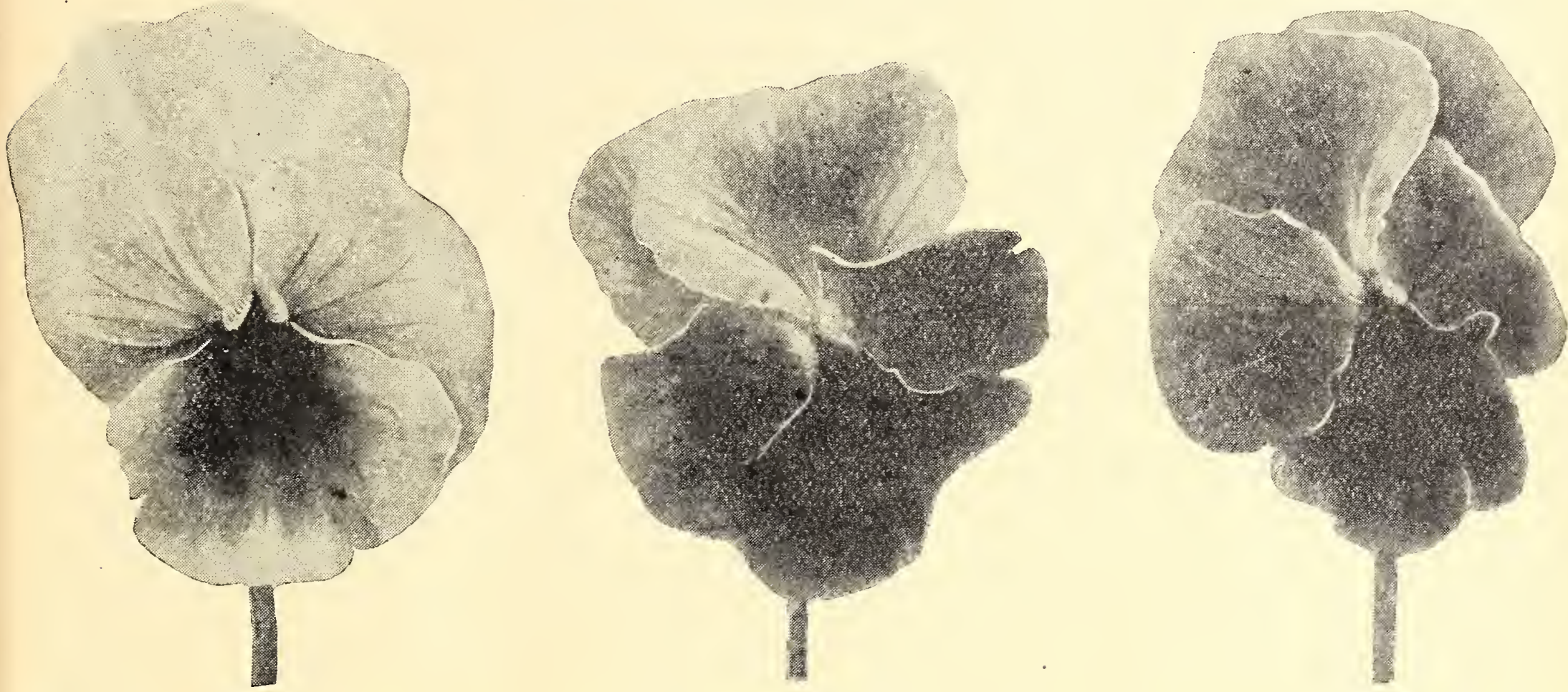

The Pansy is a plant that we all delight to grow in plentiful supply for flowers all the year. For very early outdoor bedding, the seed is. sown from August to October, in a coldframe, or in rich, moist garden beds, from which the plants can be transferred to a coldframe, setting them 2 to 3 inches apart each way before severe winter weather begins. In spring, three-fourths of them can be lifted out for bedding and the rest left to bloom in the frame. For winter blooming in a frame, set the plants about twice as far apart, and thin out half of them in the spring. Cover the blooming plants with sashes, adding a cove ering of matting or straw in very cold weather. In mild weather, remove the mats and tilt the sashes to admit light, heat and fresh air. In outdoor beds, raised a few inches above the ground, with a mulch of dry leaves and some brush to hold them in place, pansies will often winter nicely and bloom until midsummer, when a relay of young, virgorous plants should be ready to replace them. Spring sowings should be made early so as to secure good flowers during the early rains. Seed sown in a cool, moist place in June and July, and well tended, will give good flowering plants for fall. If they come into bloom in the heat of the summer, the flowers may be small at first, but as the weather becomes cooler, they will increase in size and beauty. Through summer heat the flowers are finer in a somewhat shaded place, but in almost any situation good Pansy seed will give fine flowers in spring and fall. Early fall sowings give the finest flowers. The higher-priced sorts produce the largest flowers. This should be borne in mind when ordering.

IMPERIAL MIXED. This is the finest strain of Giant Pansies it is possible to produce. It is a blend of all that is finest in Pansies from France, England and Germany. It is absolutely unrivaled in range of magnificient cloors, size and substance. To this mixture we are constantly adding the newest novelties as they are introduced, and our customers can confidently rely upon getting all the finest it is possible to procure in this choice blend. Pkt., $20 \mathrm{c}$.

CAOICE MIXED. Pkt. $5 \mathrm{c}$.

\section{PRIMROSE - PRIMULA VERIS}

TEIIOW FNGISF PRIMROSE. The plants commence to bloom when only about 4 inches high and in a little over a month from sowing the seed, and continue to grow and bloom unti Irost. The plants will live over if given slight protection and the flowers are even more beautiful the second season. Pkt., $10 \mathrm{c}$.

\section{PETUNIA}

For outdoor decoration or house culture few plants equal the Petunia in effectiveness. They commence flowering early and continue a sheet of bloom throughout the whole season until killed by frost; easily cultivated, requiring only a rich soil and a sunny position.

IARGE FIOWERING FIINGED. A strain of incomparable beauty, size and luxuriance. The flowers are exquisitely ruffled or fringed on the edges, and are enormous. Pkt., $5 \mathrm{c}$.
FXIRA IARGE FIOWIRING, DOUBII ERINGID. This extra choice strain produces about 30 per cent of splendid double fringed Howers. Pkt. 25c.

BEDDHNG MIXED. Pkt., 5c.

HOWARD'S STAR. These beautiful Petunias have large, intensely colored flowers from the centre of each of which start the points of $a$ five-rayed star, which broadens half way up, narrowing to a point at the margin of the flower. The star is a light bluish pink, deepening in color as it reaches the margin, finally blending into the dark crimson-maroon ground color of the flower. Very prolific bloomers, excellent for bedding. Pkt. $5 \mathrm{c}$.

\section{PORTULACA}

This plant will grow and bloom profusely in a dry, hot situation, where almost any other plant would soon die. It is the easiest plant to transplant, and can be taken up and set out when in bloom without being injured. It is a very pretty annual, and blooms till frost.

IARGE FIOWERING DOUBIE. Finest mixed. Pkt., 5c; $1 / 4$ oz., $40 \mathrm{c}$.

SINGLE. Choice mixed. Pkt., 5c; 1/2 0z., 25c.

\section{PYRETHRUM -FEVERFEW}

GOIDEN FEATrFR. A highly ornamental goiden yellow foliage plant, unexcelled for bed. ding. Hardy perennial; 1 1/2 feet. Pkt., 5c. 


\section{POPPY (Papaver)}

Before Tulips are fairly gone, our gardens begin to be gay with Poppies. Few flowers have th same grace of stem, ariness of poise and delicacy of tissue. For beds and borders with a background of green there is nothing finer; some sorts are admirable for naturalizing in open wooded grounds; others, like the Shirley, are beautiful for cutting. A sandy loam suits Popples best, and, as their strong tap-roots are difficult to transplant, it is well to sow seed where the plants are to bloom. Sowings made in fall and at intervals in spring will provide a long succession of flowers. Sow thinly, covering very lightly, and thin the plants to stand about a foot apart. The best plants are those grown from early sowings while the earth is cool and moist.

PERENNIAL VARIETIES. Tall, large-flowered and showy; average height, 2 to 4 feet. ORTENTALTS MIXED HYMPIDS. Finest shades. Pkt. 10c; oz. 75c

NIDICAULE-(Teeland Popny). These dwarf, bright yellow Poppies form one of the chief attractions of the garden through several months. They are most beautiful when grown in masses from seed sown every year; 1 foot. Pkt. 10c; oz. $75 \mathrm{c}$.

ANNUAL VARTETIES. This section includes double and single flowers of greatly varying sizes, self-colored and daintly edged. 'All are easily cultivated and greatly admired. Average height, 3 feet.

CARNATION-FLOWLRED DWARE. Large carnation-like flowers, very double and most excellent for massing. Pixt., $5 \mathrm{c}$.

SHIRLEY MIXED. Considered by many the finest poppy in cultivation. The colors range from deepest red through the lighter shades of red and pinks to pure white. Pkt., $5 \mathrm{c}$.

MIXED SINGLE. All colors. Pkt., 5c.

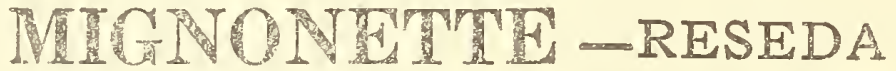

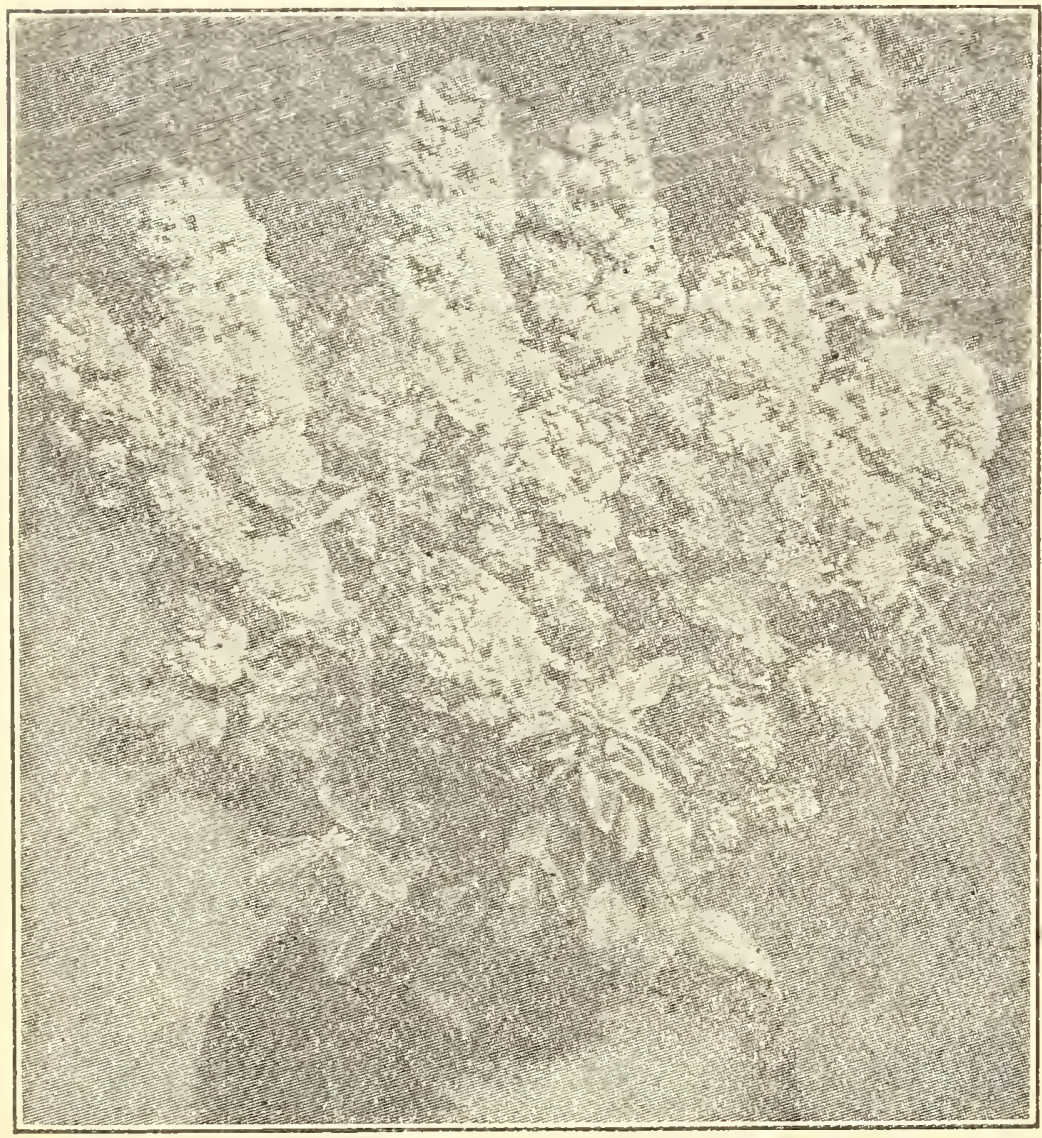

MIGNONETTE

This deliciously fragrant annual is a favorice with all. For best results give a cool location.

GOIDEN QUEEN. Golden yellow flowers exceedingly fragrant. Pkt. 10c.

ODORATA. Mixed, many orts. Pkt., 5c.

MACHET. Of dwarf habit with large number of flower stalks. Very fragrant. Pkt., 10c.

\section{SALVIA}

Gorgeous effects can be produced by massing on the lawn or in the garden, or planted in rows along a sunny drive. A perennial. but blooms the first season from seed.

SPIENDENS. Bears a brilliant mass of scarlet bloom until frost. Pkt., $10 \mathrm{c}$
SCABIOSA (Mourning Bride). One of the handsomest summer border plants, producing in great profusion splendid flowers for table bouquets, etc. Hardy annual; 2 to 3 feet.

Double. All colors mixed. Pkt., $5 \mathrm{c}$.

SCARLET RUNNER. An old favorite prized not only for the bright scarlet flowers but well for the delicious beans it produces. Pkt., $5 \mathrm{c}$.

\section{STOCRS}

Stocks are among the finest annuals. The seed will germinate in from 3 to 5 days, and the plants commence to bloom in about 10 weeks, and continue until frost. Give good rich soil and good cultivation to get double flowers. In warm climates shade from the noonday sun. They are very thirsty plants; be sure to water well.

GTANT FIOWEIED TEN WEEKS. In finest mixture. Pkt. 10c.

CHOICE MIXED. Pkt., 5c.

\section{SUNFLOWER}

GIOBOSUS FISTUIOSUS. Flowers immense, from 12 to 15 inches in diameter. Globular and extremely double, the mosi effective of all annual sunflower. Pkt., $5 \mathrm{c}$.

\section{SWEET WILIIAM}

Exceedingly beautiful ant showy, plants hardy perennials.

SINGIE FINEST MTXED. Pkt., $5 \mathrm{c}$.

THUNBERGIA.. (Black Eved Susan). Beautiful, rapid growing annual climbers, useful for boxes, vases hanging baskets and the like. Has profusion of flowers in buff, white and orange with dark eyes. Prefers warm sunny situation and grows 4 feet high. Price per pkt., $5 \mathrm{c}$.

\section{VERPENA}

Pretty annual creepers finwering all summer.

MAMMOTH WHITE. Pkt., $10 \mathrm{c}$.

MAMIOTI SCARLET. Pkt., 10c.

MAMIIOTH PURPLE. Pkt., 10c.

CRAIDIYIORA TYIEIDS. In finest mixture. Pkt., 5c.

\section{VIOLETS}

\section{SWEET SCENED BLUE. Pkt., 10c. WILD CUCUMBER}

Most rapid climber known. Pkt., 5c; $1 / 2$ oz.

\section{WILD FLOWER GARDEN}

Choice mixture of annual flowers. Over 25 varieties. Large plet., 5c.

\section{ZINNIAS}

Are undoubtedly among the most showy and ornamental of flowers for either beds or borders

CHOICE MIXED. Very fine. Pkt, 5c.

DAHLIA, Flowering. New. Very large. Pkt, 


\section{SWEET PEAS \\ ¿PENCER VARIETIES OR GIANT ORCHID FLOWERING}

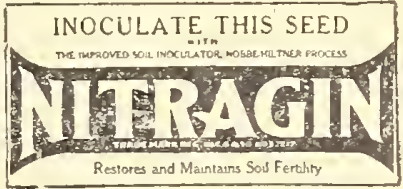

Because of such enormous size, of waved or fluted appearance and charming blendings of harmonious colors, this New Type can only be appropriately described as Truly Gigantic "Orchid fowered." The flowers are not only of extremely large size, but are distinct in having the outer edges of the standard and wings beautifully crumpled or waved; the tissue being so full that there is not room for it to lie flatly expanded or smoothly rolled. The standard is broad and tall; the wings are broad, well spread and held erect by the keel.

The stems are very long and strong, and remain in bloom for a much longer period than nther varieties of Sweet Peas. In size and quality the blossoms cannot be surpassed for cutting.

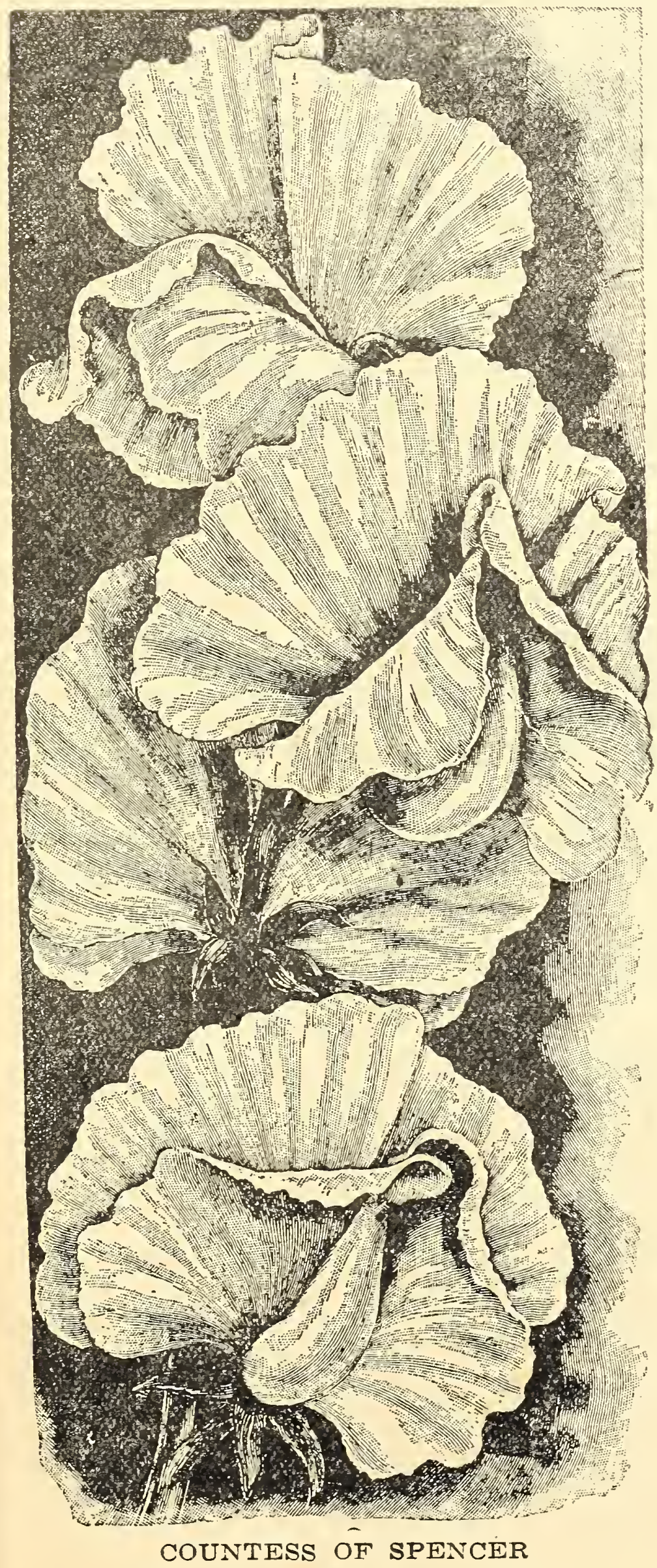

AMPrICA. Red and White striped.

APEIF BLOSSOM. Rose White Wings.

ASTA OIN, Lavender.

CIARA CURTIS. Primrose.

COUNTES OF SPRNCER. Deep Pink.

DAINTY SPENCER. White Pink edge.

DOBPIES CREAM. Deep Cream

EIFRIDA PEARSON. Shell Pink

F'IOPA TORTON. Light Blue.

IELIN PIPRCE. Blue White, uncottled.

AERCUIES. Laree Soft Pink.

IIUIMINATOR. Salmon Cerise.

IING EDWARD. Pure Self Red.

KING WIITE, Giant White.

MARGARTT ATIEE. Rosy Salmon.

MARGARET IMADISON. Azure Blue.

IIARIE CORREIII. Bright Rose.

MARTIA WASHINGTON. White and Deep Pink edge.

MRS. TOUTZAIN, Apricot Pink.

IUUIAN. Giant Chocolate Brown.

OTHEIIO. Dark Maroon.

THOMAS STEVENSON. Orange.

WEDGEWOOD. Silvery Lavender.

All of above Pkt., 10c; oz., 25c; 1/4 1b., 75̃c.

\section{SUPERB MIXTURE OF GIANT SPENCER HYBRIDS}

Containing all varieties named above. Per plat 10c; per oz., 20c; $1 / 4$ ib., 70c.

ECIKFORDS EXTRA FINE MIXED.

Contains about fifty varieties and is a splendid assortment of shades and colors. Pkt. 5c; oz., $15 \mathrm{c} ; 1 / 4 \mathrm{lb}$. $50 \mathrm{c}$. 


\section{HARDY PERENNIAL ROOTS AND PLANTS}

Or all the plants that are cultivated for purely ornamental purposes, there are none that have made the rapid strides in public favor like the Hardy Perennial or old-fashloned garden flower. The love for them of late years has increased so much and it is not surprising when we consider the many uses to which they adapt themselves so readily. There are so mang of them that will give an abundant blossom the same year as planted, and for cut flowers we know of no class of plants that will give the same satisfaction for so little care. Planting should be commenced as early as possible, usually about ten days after the irost has ifted. If this is done the plants get well established before the hot weather comes in. In preparing the border, dig deeply and freely, add well decayed stable manure. Plant only when the soil is in a iriable condition. It is better to heel plants in if the ground is not in good working order and wait until favorable weather, rather than plant in wet and clammy soil.

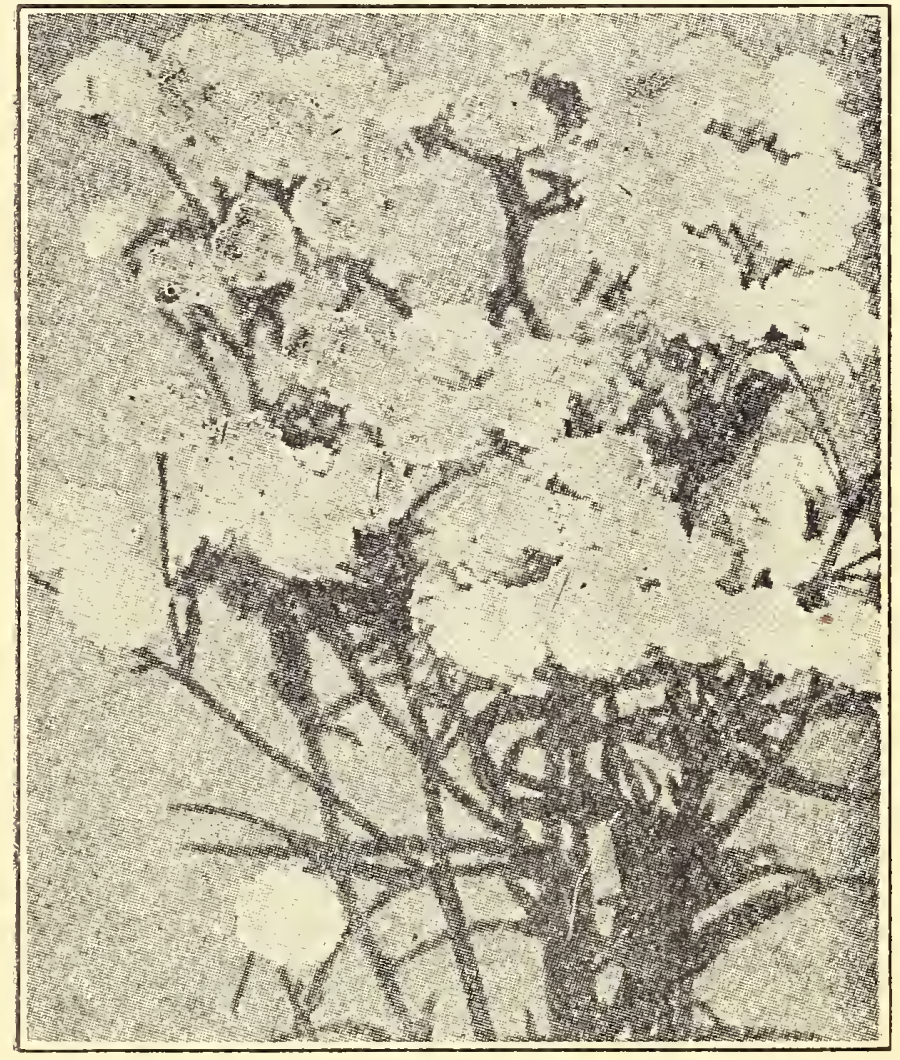

ACHILLEA "THE PEARL"

\section{ACHILLEA}

"Frig PIAI." Flowers borne in the greatest profusion the entire summer on strong, erect stems, 2 leet high, of the purest white; as a summer cut bloom it is of great value.

\section{DAISY}

BURBAITE'S SHASTA. Large snowy-white fowers, in bloom continuously throughout the summer and fall.

\section{DICLYTRA OR DICENTRA}

8PFCYABIIS (Bleeding Beart or seal Flower). An old-fashioned favorite; its long racemes of graceful heart-shaped pink flowers are always attractive; it is used largely for forcing, and is perfectly at home in any part of the hardy border, and especially valuable for planting in the shade.

\section{DELPHINIUM}

\section{(Zardy Iarispur)}

These are deservedly one of the most popular subjects in the hardy border, bold, attractive and highly prepossessing plants of easlest culture; perfectly hardy. They will establish themselves in almost any garden soll, but respond quickly to liberal treatment.

\section{AQUILEGIA OR COLUMBINE}

The Columbines are one of the most elegant and beautiful of hardy plants, producing their graceful spurred flowers on stems rising 2 leet or more above the beautifully divided foliage, and are highly prized for cutting.

They are not at all particular as to soll or location, although they prefer a sandy loam and moist but well drained, sunny position.

COFRUIEA (Bocky Mountain Columbine). Bright blue and white, long-spurred flowers.

\section{COREOPSIS}

IANCEOIATA GRANDIFIORA, One of the most popular hardy plants. The flowers are rich golden-yellow, of graceful form and invaluable for cutting: the main crop comes during the latter part of June, but it continues in bloom the entire summer and autumn; it succeeds everywhere.

\section{GAILLARDIA}

\section{(Blanket Flower)}

GRANDIFIORA. One of the showiest hardy plants, growing about 2 feet high and succeeding in any soil in a sunny position; beginning to flower in June, they continue the entire season. The large flowers are of gorgeous coloring. The center is dark red brown, while the petals are marked with rings of brilliant crimson, orange and vermillion, and often a combination of all in one flower; excellent for cutting.

\section{GYPSOPHILA}

\section{(Baby's Breath)}

The Gypsophilas will thrive in any soil in sunny position, and on account of their grace fully arranged large panicles of minute flowers, should be in every garden.

PAITICUIATA. A beautiful old-fashioned plant, possessing a grace not found in any other perennial. When in bloom during August and September it forms a symmetrical mass 2 to 3 feet in height, and as much through, of minute pure white flowers; forming a beautiful gauze. like appearance. For cutting it is exquisite, especially in combination with high-colored flow: ers.

\section{HOLLYHOCKS}

Whether planted with shrubbery, as clumps on the lawn or in the mixed border their colossal spikes of bloom produce bold and showy effects, which cannot me secured with any other flowering plant. The Hollyhock requires a deeply dug, well-drained soll, enriched with thoroughly decayed manure, and should be liberally supplied with water during dry weather. A slight protection through the winter will be beneficial; a light covering of loose leaves or evergreen branches will be suitable for this purpose. 


\section{AGROSTEMMA}

(Rose of Heaven)

A remarkably pretty hardy plant, having glowing crimson flowers like a single pink and silvery white foliage.

CANTERBURY BELLS (Campanula Medium). Beautiful large bell-shaped flowers in blue, rose and white colors. The medium is the most satisfactory of the Campanulas. It grows 3 feet high on good soil and blooms for a long time, if flowers are cut immediately upon fading and if planted in a half-shady place.

\section{IRIS}

Easily grown and live for years. Bloom for several weeks.

\section{HARDY, GARDEN PINKS (Mixed)}

Strong. year-old roots grown from seeds from fine strains.

\section{SWEET ROCKET}

An old-fashioned hardy plant yet a most desirable one. It grows 2 to 3 leet high and blooms treely bearing large clusters of white, lilac and purple flowers. Fine for border or for planting among shrubbery.

\section{MATRIMONY VINE}

A vigorous, hardy climbing plant. It covers a great amount of space in a short time, and every new growth is at once covered with bright purple flowers, which are succeeded by brilliant scarlet berries nearly an inch long. It will grow and thrive in any situation, either shade or bright sunlight.

\section{SWEET WILLIAM}

Well known, free blooming. hardy perennial plants which produce masses of lovely, brilliant, sweet-scented flowers through a long period, making a splendid effect in beds. One foot high. Flowers are borne on heads or umbels with individual flowers nearly an inch across. Color white, pink, crimson, purple, etc., with rich markings.

\section{HARDY PHLOX}

The beauty and usefulness of these grand border plants give them a deservedly first place amongst hardy plants. They succeed in almost any soil enriched with manure, but are much benefited by a mulching of well rotted manure in spring, and in hot weather an occasional soaking of water. If the first flower spikes are cut off as soon as over, and the plants are given 2 good soaking, a second crop of bloom extending until late in the fall may be expected. The best effects to be had with Phlox are produced bs planting masses of each color.

BRIDESMaID. Pure white, with large crimson-carmine eye.

RICHARD WALTACE. A fine orange scarlet with crimson eye. Very fine.

ECIAIREUR. Brilliant rosy magenta with large lighter halo. An excellent varlety.

F. G. VON LAssbuRG. The purest snow-white in cultivation. Individual flowers largèr than any other white. Extra fine.

.MRS. JENKINS. Pure white, large flowering variety.

R. P. STRUTHERS. Brilliant leddish purple, with very large dark red eye. New.

HODUR. One of the best of the deep rose colored varieties.

SUBULATA ROSEA. A pretty, delicate, soft pale rose, with distinct red eye.

\section{RUDBECKIA}

\section{(Cone Flower)}

Indispensable plants for the hardy border; gro' and thrive anywhere, giving a wealth of bloom, which are well suited for cutting.

"GOIDIP GIOW." We question if an' one hardy perennial plant has ever met with freater popularity than this. It is a strong. robust grower, aitaining a helght of 5 to 6 feet, and produces masses of double golden yellow Cactus Dahlia-like flowers from July to September. 


\section{PEONIES}

\section{Hardy as the Oak---Once Planted all is Done Increasing In Size and Beauty With Age}

The Peony is now beyond all doubt the most popular of all the hardy, herbaceous plants. During recent years it has been so vastly improved that now large acreages are being devoted to growing cut flowers for market, so beautiful and highly prized are the blossoms. Peonies will thrive anywhere and in any garden soil. Plant in good soil, but not on freshly manured ground. All the fertilizer should be placed on top after the ground is frozen. A liberal dressing every year will produce fine flowers. Set the roots slanting with the topmost buds three inches below the surface.

For permanent planting, Peonies should be set 3 to 4 feet apart each way, and left undisturbed for at least ten years, when they may be taken up, divided and re-set.

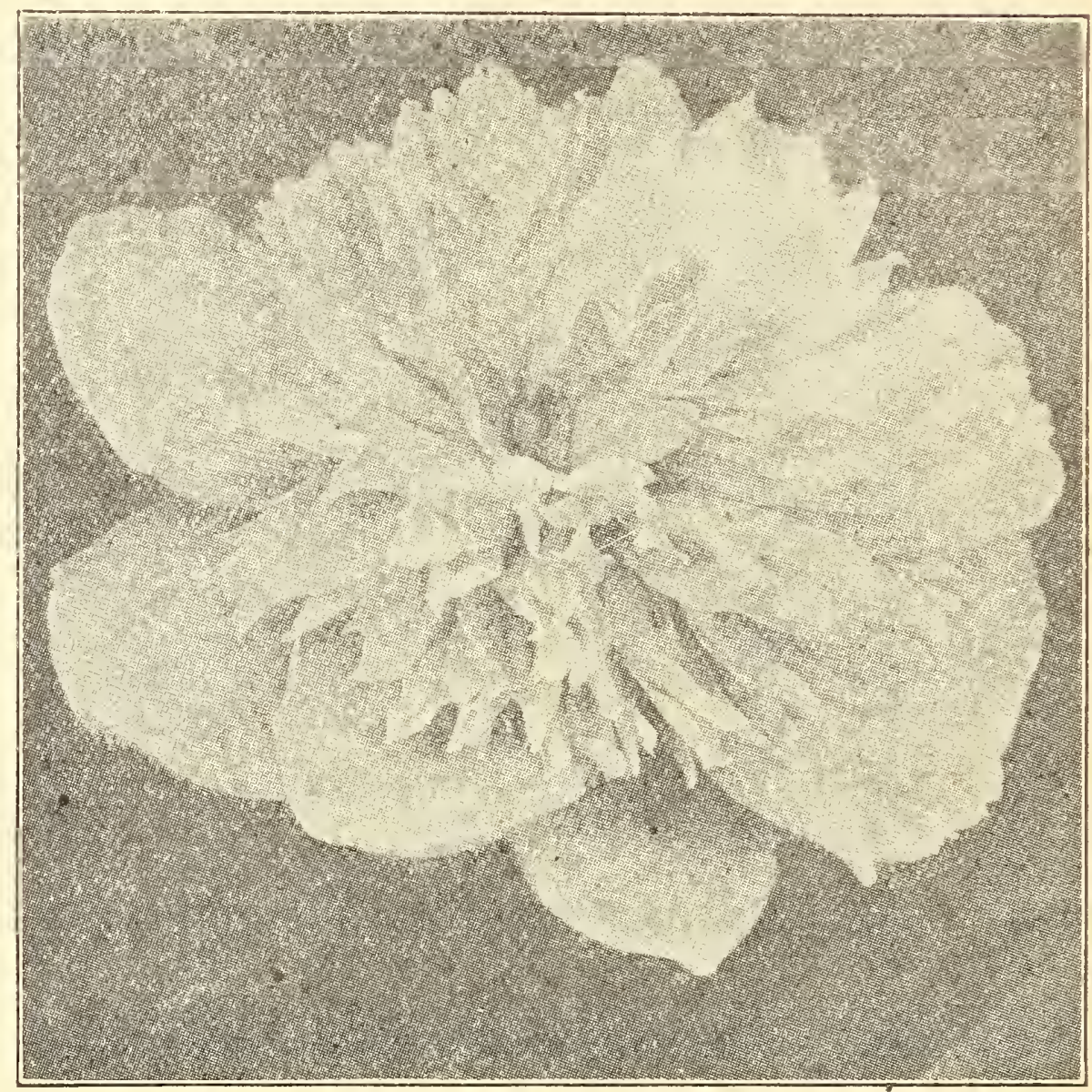

\section{IVHITE VARIETIES.}

FESTIVA MAXIMA. The best known Peony; flow er of immense size, 7 to 8 inches in diameter; snow white, with some red spots on the edges of the center petals. Very Early.

Iadam de Verneville.-White mottled and rariegated with rose. Early.

Queen Victoria.-Center petals delicate cream changing to white; outer ones broader and delicate rose color. Early.

Chinese Alba.-Pure white except outer petals which are tinted with pink; center finely fringed. Mid-season.

\section{RED AND PINT VARIETIES}

GRANDIFLORA. A late blooming Peony with flesh-pink flowers borne on tall, strong stems.

MADAME GELSLER. Very large: delicate, clear pink, ligbter in the center; very fragrant; free bloomer; exceptionally pretty in the bud; a quality flower in every sense It is unexcelled as a cut flower. Blooms in mid-season.

CLAIRE DUBOISE. A bright dark rose; exceptionally fragrant; late.

LIVINGSTON. A large lose-colored flower with purplish tinge. A strong grower.
Expo Universal.--Pale rose striped with crimson. A robust plant with tall stems. Mid-season.

Alexandria. A large bright light rose colored flower. A very tree bloomer. Mid-season.

Paul Neron.-Broad outside petals, purplish-rose; inside, fringed, straw color tipped with white; celfter, bright rose.

Sarah Bernhard-Carge purplish rose A vigorous plant and one of the good ones.

- Francis Ortegat.-A large full double crimson shading to light rose. Early

Terry No, 2.-A light lavender pink. Mid-season.

L'Esperance.-Light rose edged with white. A large, fine double flower. One of the best early peonies.

Duchesse d'Orleans.-Large flower, bright rose and full double. Mid-season.

Offincinallis Rubra.-A deep dark rose color. blooming in late mid-season.

Marguerite Windheim.-A rich dark red flower, very double and a rapid crower. The best deep red we have seen. Late. 


\section{SUMMER FLOWERING BULBS, ROOTS AND PLANTS}

\section{CANNAS}

The Canna has long been considered an almost indispensable plant for flower garden or lawn embellishment. So popular have they become and so thoroughly are they adapted for bedding ourposes, that every summer thousands of them are planted in all the parks, cemeteries and private places in the country. A more gorgeous sight can scarcely be imagined than the many great masses of them of all colors we erequently see. The flowers are produced in great clusters throughout the entire summer.

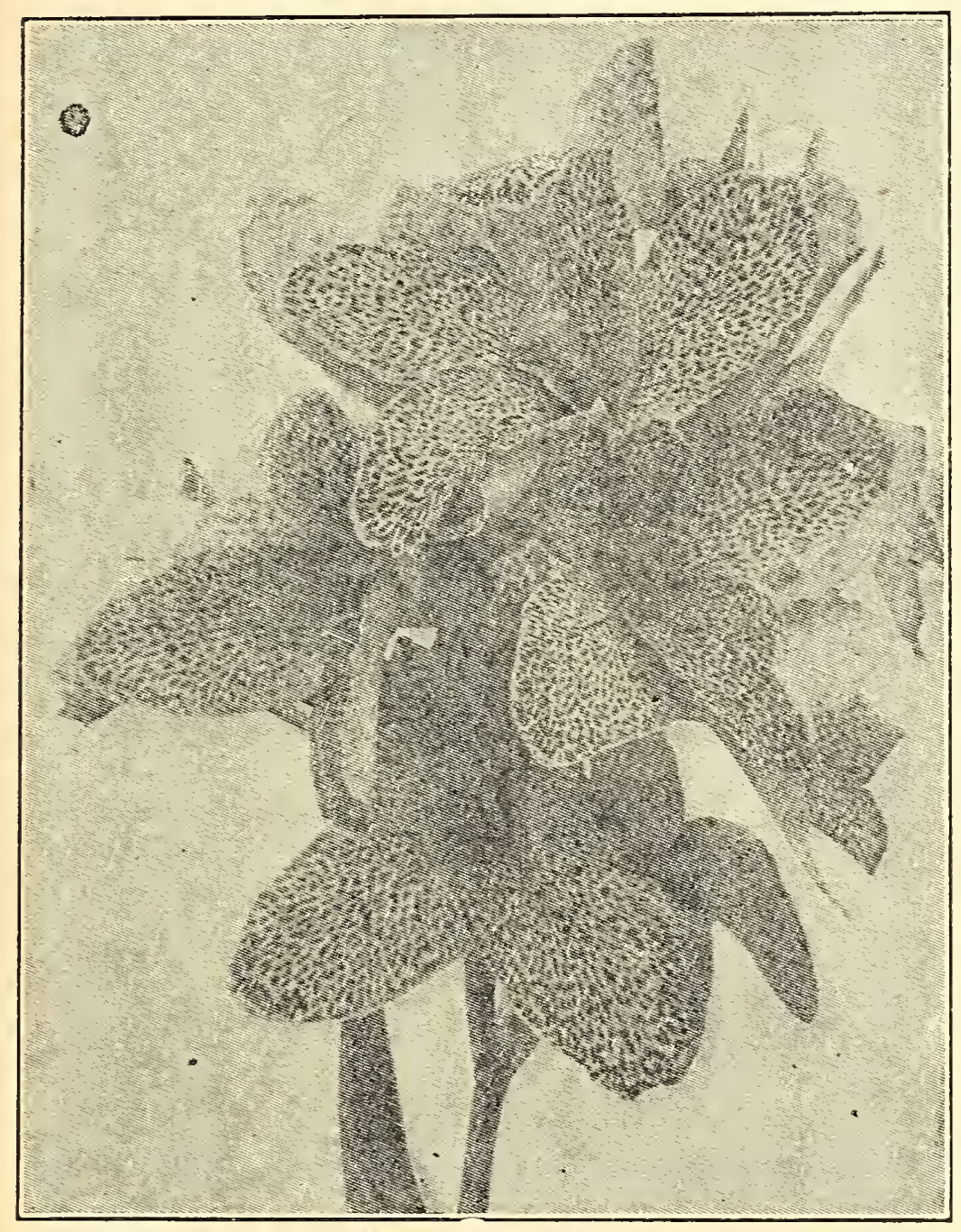

CANNA, FLORENCE VAUGHAN,

CEARISS HENDERSON. Three feet. An ex. cellent bedder; foliage deep green with narrow bronze margin; flowers large and produced in great abundance; color rich crimson.

FIORENCE VAUGRAN. Five feet. A mag. nificent variety; golden yellow, dotted with spots of bright scarlet; foliage green.

ZING EUMBERT. Five feet. In this grand Canna we have a combination of the highest type of flowers with the finest bronze follage. Its flowers measure six inches in diameter, produced in gigantic trusses, a brilliant orange-scarlet with bright red markings; follage broad and massive, of a rich coppery-bronze.

MADAMz CROZY. Four feet. Stlll the leadIng Canna of its kind and color. The flowers are borne in great clusters; color a glossy brilliant vermillion bordered with gold: foliage bright
HUNGARIA. - The ideal pink bedding Canna; tow. ers large, in good sized trusses. An unusual shade and one not found in any other variety. Height, 31/ feet.

SOUVENIR D'ANTOINE CrOZI. Four feet. The best of the gold-bordered varieties; flowern large; color an intense scarlet-crimson, rich and dazzling, bordered with golden yellow; 1oliago green.

AUSTRIA. Golden yellow, dotted red. Orchid flowering. Green foliage, 5 to 6 feet high.

ALLEMANIA. 4 to 5 feet. Green foliage. The outer petals are scarlet, with broad yellow border. Inside of bloom scarlet and dark red.

VENUS. 4 feet. A rosy pink with border of creamy yellow. Green foliage.

MUSAFOLIA. 6 feet. Large green leaves. Used for backgrounds. Flower small.

\section{CINNAMON VINE}

A lovely climber, taking its name from the poculiar fragrance of its delicate white nowers. The leaves are heart-shaped, bright, glossy graen. Growth is very rapid, reaching about eight foot in height; quite hardy.

\section{MADEIRA VINE}

The Madejra vine is of rapid growth, with dense and beautiful foliage, twining to grost height. It grows anywhere, but does better in a warm, sunny, sheltered location. It is also a very pretty plant for training around the win. dows in the house.

\section{TARDT TITHS.}

AURATUA. The glorious, gold-banded lily of Japan and one of the most superb plants in cult1vation. Its immense ivory-white fowers are thickly studded with yellow and crimson spots, while in the center of each petal is a golden band, fading at its edges into the white. Such choice bulbs as we offer, if well cared for, will give from five to ten magnificent flowers the first year and under good cultivation will, after becoming well tablished, give from ten to fifty blossoms.

SPICIOSUM AIBUM. Pure white flowers Fith a greenish band through the center of each petal; of great substance, very fragrant. One of the best for general culture.

SPFCIOSUM RUBRUM. No words can overstate the brilliant beauty of these famous Japanese lillies. The six broad white or pink petals are thickly dotted with rose or crimson spots and the graceful form and brilliant color make them very effective and desirable. Especially thrift Bulbs. 


\section{SUMMER FLOWERING BULBS}

\section{GLADIOLI}

You are sure of fine flowers if you plant Gladiolus, the most attractive of all summer flower ing bulbs. They need only a little culture to keep the weeds down, will grow in any good garden soll and with ordinary rainfall seldom fall to fiower the same season because their growtin is assured from the stored up strength in the bulbs. Wonderful improvements have been made recently in the size and colorings of these flowers. Plant about the 1st of May.

AMFRICA. One of the best Gladioll in existence. The color is a most beautiful soft pink, very much like the Enchantress Carnation. Individual flowers are very large and massive, and as a. group or in vases there, is no other flower which can excel it in effectiveness.

PEACE. Flowers are of perfect paper white, with a slight pink shade on lower half of the petal. The spike is set solid and perfect with the flowers from top to bottom.

MLDS. FRANCIS RING. A new variety which excited great comment and admiration, both for size of flower and beauty; the color of the flower is a light scarlet; the flowers are very large, usually measuring from $31 / 2$ to 4 inches in diameter and are borne on long stems with from 4 to 6 flowers open at a time.

BARON HULO'T. Good-sized flower, well arranged on straight spikes; color, dark violet bordering on blue.

HALLEY. Delicate salmon-pink, slightly roseate, the lower petals showing a creamy blotch bisected by a red stripe. One of the earliest to bloom.

PINK BEAUTY. The earliest flowering Gladiolus. Rose with dark blotch.

SCHWABEN. An imported variety having strong splkes with well expanded flowers of clear yellow with dark blotch in center.

PANAMA. A favorite with Gladiolus fanciers. Similar to America, but is of a rich rose-pink.

WILLY WIGMAN. A white ground delicately tinted rose and having a large carmine blotch on the lower petals. A most desirable variety.

WAR. One of the best Red in existence.

PIRRFCTION MIRTURE. Includes the above and many other named varieties selected to give a proper color proportion. There is nothing finer than this mixture.

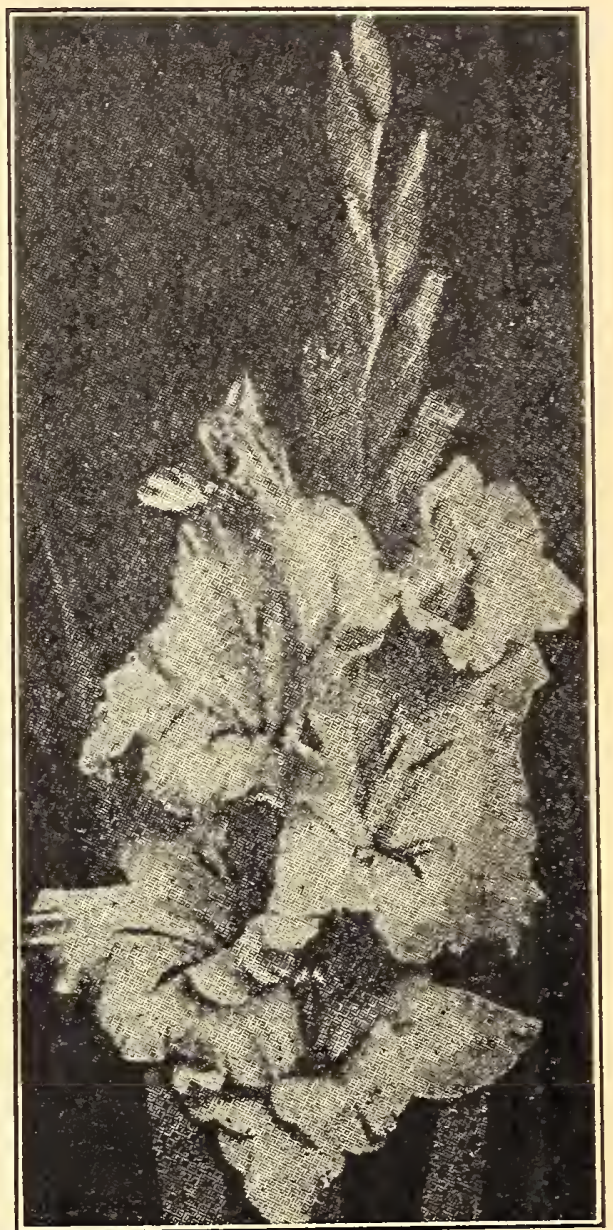

KUNDERDI GLORY.

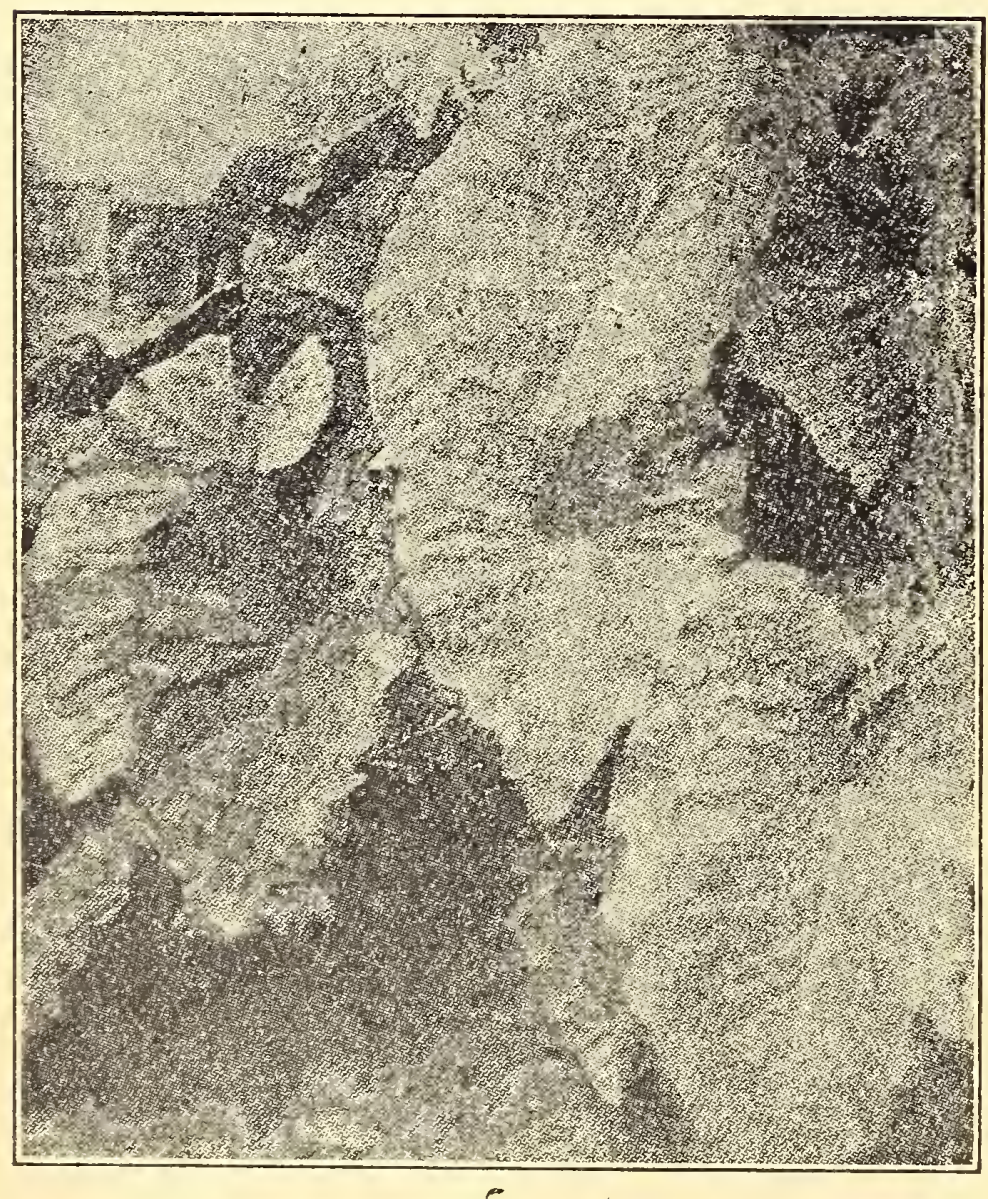

SALADIUM ESLULENTUM.

\section{CALADIUM ESCULENTUM}

\section{(अephant' अar.)}

FSCUIFIrUM. This is one of the handsomest of ornamental leaved plants. Roots obtained in the spring will make good plants in the summer. Leaves three feet or more in length, nearly as broad. Mammoth bulbs and Selected bulbs.

\section{TUBEROSES}

The bulbs we offer are unsurpassed in blooming qualities and purity of strain. In this latitude May 1st is ample time to plant in the open grousd, but the bulbs can be started in pots much earlier if desired.

FXCFISIOR PEARI. Short stalks, long spikes, large flowers, full, double and sweet; mammoth bulbs. Mexican long spike crest single flowers.

MEXICAN. Single, ever-blooming. 


\section{DAHLIAS}

These plants are so well known that no description is necessary. No garden should be without some of these brilliant autumn flowers.

The Dahlia requires a sunny location in light, well fertilized soil, a liberal supply of water and plenty of space in which to grow. Roots ready for delivery in April.

\section{DECORATIVE DAHLIAS}

MINNIE BURGLE. A large dark red flower of beautiful form and borne on long stems.

QUEEN MARY. A beautiful true shade of pink. Large flowers on stiff stems.

TANGIER RED. A sturdy grower. Flowers a rich crimson of fine form.

PRINCE OF ORANGE. Very striking. Soft golden yellow tipped bronzy red; effective under artificial light, perfect form, on long, erect stems.

ELlA CLINE. Pure white. Very large, full flowers. Florets serrated at points, giving the flowers a fine feathery appearance.

\section{CACTUS DAHLIAS}

J. H. JACKSON. Beautiful pure garnet. Splendid form and free bloomer.

BIANCA. Deep rosy pink with lighter center. A distinct and valuable variety as the flowers keep a long time after cutting.
MRS. WARNER. A magnificent flower of largest size with suffused blush.

MRS. LONSDALE. Very large, clear salmon pink, the best cactus.

\section{SHOW DAHLIAS}

DOROTHY PEACOCK. Show. Delicate pink. Well-formed flowers with long stems. Very desirable for cutting. This is an old standard dahlia which every dahlia grower has retained from its introduction, on account of its exquisitely beautiful color and perfectly round, ball-shaped flower. One of the freest blooming dahlias in cultivation.

CUBAN GIANT. Richest dazzling cardinal red. Strong, rigorous grower and free bloomer on long stems. Best red show dahlia for cutting.

ROBERT BROOMFIELD. Large, pure white. Reliable.

YELLOW DUKE. A free flowering, long stemmed variety; its full quilled blooms of primrose jellow being exceedingly soft and pretty.

UNNAMED DOUBLE DAHIIAS. Good sorts. Red. white, pink and yellow.

\section{OUR DAHLIAS ARE ALL GROWN IN DOUGLAS COUNTY, NEBR.}

\section{FERTILIZERS, INOGULATION and INSEGTICIDES}

All tools, sprayers, insecticides, fertilizers, poultry supplies, etc., listed on following pages, subject to market changes.

PULVERIZED SHEEP MANURE. Especially pepared and recommended for lawns, parks, boulevards, flowers and shrubbery of all kinds. It is in a finely pulverized state, absolutely free of weed seeds, due to the extreme heat to which it is exposed during manufacture, and contains food in quickly available form. It is also practically odorless and does not give the lawn an undesirable appearance when applied.

HYDRATED LIME. Lime is the proper material to use on sour or acid soils. Garden soils and lawns that have been cropped year after year need lime. Lime acts as a corrective. Though not considered a fertilizer, it does liberate the elements in fertilizers and soils necessary for plant growth. Lime should be applied to the lawn in the fall and early spring, 1 lb. to $25 \mathrm{sq}$. ft. A trial will prove its value. $10-1 \mathrm{~b}$. bags, 35c. 50-1b. bags, $\$ 1.20 .100-1 b$ bags, $\$ 2.00$.

\section{NEBRASKA SEED CO.'S LAWN FERTILIRER}

Lawn grass is a voracious feeder and will not th rive and hold its beautiful dark green color and velvety appearance unless it receives a sufficient supply of suitable food. Because so few appreclate this fact is the reason there are so many poor, rusty-looking lawns. Btable Manure is unpleasant to handle, Ill-looking and decidedly odorous, and is also full of waste material. It contains weed seeds which are obnoxious, and it often takes years to eradicate the weeds, causing an unnecessary amount of labor. All these objections are obviated by the use of our Iawn Fer. tilizer.

DIRFCMIONS FOR USF.-The first application should bo made early in the Spring, as soon as the frost is out of the ground, at the rate of 25 pounds of fertilizer to every 1,000 square feet of lawn, evenly distributed. For seeding down a new lawn scatter double the amount, say 50 pounds of fertilizer, broadcast, on every 1,000 square feet, and rake it in thoroughly before sowing the seed.

Price 10 lbs., 60c; 50 lbs., $\$ 2.50 ; 100$ lbs., $\$ 4.00$

\section{N11RATE OF SODA, OR CHILI SALTPETER}

NITRATE OF SODA is the cheapest and best form in which to apply nitrogen to plants. Gardeners who are using farm manure should continue to use it, but use Nitrate of Soda in addition to other fertilizers.

BONE FERTILIZER. Bone fertilizer is recognized as a reliable all around fertilizer. It is especially rich in nitrogen and other plant requirements. Bone meal fertilizer is used for garden, lawn, hardy perennial beds, potting soil, and is a valuable fertilizer to be used for indoor plants, bulbs, etc., especially to be recommended for Ferns. 1 lb., 10c; 5 lbs., $40 \mathrm{c} ; 10$ lbs., 60c; 00 lbs., $\$ 2.50 ; 100$ lbs., $\$ 4.50$.

worms, cabbage lice and worms. 1 lb., 20c; 5 lbs. $75 \mathrm{c}$

BUG DEATH. This is a fungicide, insecticide and plant food combined. 1 lb. Pkg, 20c: $3 \mathrm{lb}$. pkg. 50c; 5 lb. pkg. 75c; $12 \frac{1 / 2}{2}$ lb. pkg. $\$ 1.50$.

BLACK LEAF 40. A concentrated solution of nicotine sulphate for spraying vegetables, fruits and flowers to destroy sucking insects. One oz. bottle, $35 \mathrm{c} ; 1 / 2 \mathrm{lb}$. tin $\$ 1.00 ; 2 \mathrm{lb}$. tin $\$ 3.25$.

TOBACCO DUST. For dusting plants affected with aphis, also used on squash vines and melons and now largely used for fumigating. $1 \mathrm{lb} .10 \mathrm{c}$ 5 lbs., $40 \mathrm{c} ; 25$ lbs., $\$ 1.50$.

FEROSFITE FMUISIOAT. (Liquid.) Used as a summer wash against scale, plant lice and aphis Ready for use by simply adding water. Qt., 5bc: $1 / 2$ gal., $\$ 1.00$; gal., $\$ 1.50$.

NIKOTEFr. An economical and powerful nico. tine extract. One part to 600 of water is sufficiently strong to kill all insects except scale, for which use 1 to 400 . I oz. $35 \mathrm{c} ; 1 \% / 4$ oz. $55 \mathrm{c} ; 1 / 2 \mathrm{lb}$. $\$ 1.10 ; 1$ lb. $\$ 2.00$.

SLUG SHOT, HAMMOND'S. To destroy potato bugs and those on tomato and egg plants, currant worms, cabbage lice and worms. 1 Ib., $20 \mathrm{c}$; 5 lbs. 


\section{DEVOE \& RAYNOLDS CO. (1) \\ ESTABLISHED

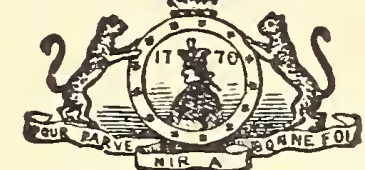 \\ IH 275 is \\ NEW YORK$$
\text { PARIS GREEN }
$$ \\ CHICAGO}

\section{DEVOE PURE PARIS GREEN}

The old reliable, a strong effective poison for potato bugs, tobacco and other leaf-eating insects. Can be applied either dry or in a solution of water. DEVOE, the strongest and brightest Paris Green on the market.

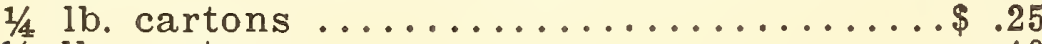

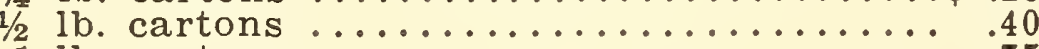

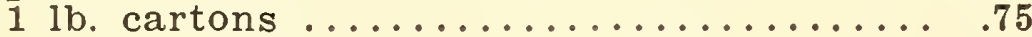

\section{DEVOF CALCIUM ARSENATE}

Dry Powdered Form

For the control of potato bugs. Calcium Arsenate is a lighter, more fluffy powder than Arsenate of Lead or Paris Green-more bulky. When used dry, will dust more plants per pound, and when mixed with water will stay in suspension better and give you better and more uniform distribution. Lead Oxide in Arsenate of Lead has no insecticide or fungicide value; but Calcium Arsenate is made on a lime base which has fungicide value. Lime adheres perfectly to foliage; will not wash off easily and is white. For protection against the potato beetle, cabbage and tobacco worms.

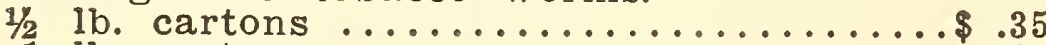

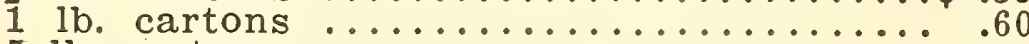

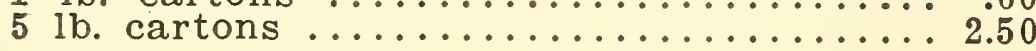

\section{DEVOE ARSENATE OF LEAD}

Dry Povvdered Form

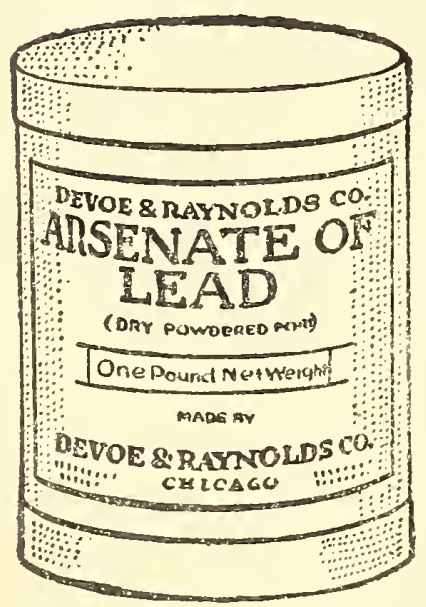

The perfect insecticide. An effective insecticide for leaf-eating insects and particularly suitable for very tender foliage. Due to the light, fluffy character of this material and its adhesive qualities it insures quick and effective control. Under favorable conditions will not injure the foliage. Can be used on apple, pear, peach and plum trees, potatoes, corn and vegetables of all kinds that may be attacked by leaf-eating insects.

1/2 Ib. cartons ..............\$.40

1b. cartons . $\cdots \cdots \cdots \cdots \cdots \cdots+.75$

\section{DEVOE ARSENATE OF LEAD-Pulp Form}

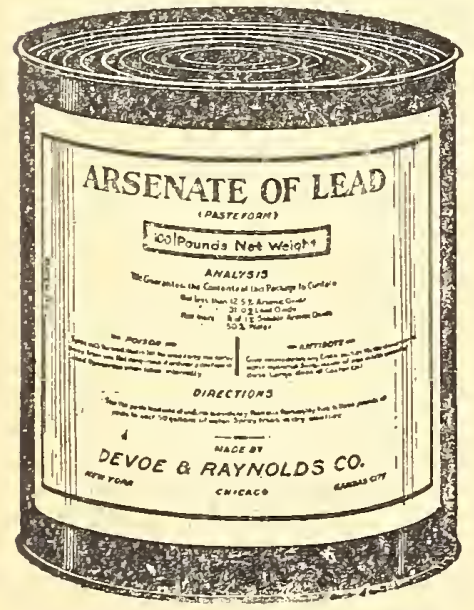

Paste Arsenate of Laed is better than government requirements in the matter of percentage of Arsenic Oxide. An effective insecticide chiefly for many of the bugs, worms and moth that fruit growers have to contend with. It comes in paste form and can be easily mixed with water. It forms a milky film when sprayed on foliage which does not readily wash off with rain. Good for potatoes and tobacco and all kinds of fruit trees. 1 lb. cans .................... .45

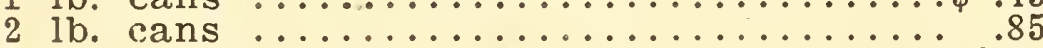

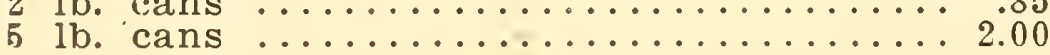

\section{DEVOE BORDEAUX MIXTURE}

\section{Dry Powdered Form}

The best fungicide for curing or preventing blotch, rot, $\mathrm{mildew}$, blight, leaf curl, scab or other fungous diseases on fruit and plants, if used dry.

For potatoes, dust without reduction, 4 to $5 \mathrm{lbs}$. per acre (according to size of vines).

For fruit trees, dust after reducing one lb. of Dry Bordeaux with 20 lbs. of lime dust.

For spray: To make the equivalent of 4-4-50 mixture, use one pound of Dry Bordeaux Mixture to 61/4 gallons of water. For 5-5-50 mixture, use 1 pound to 5 gallons of water.

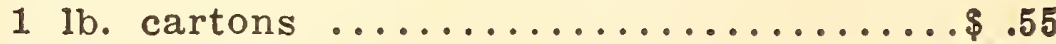

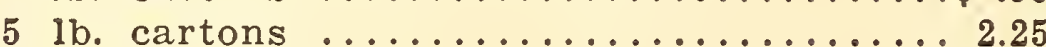

\section{DEVOE "SURE NOXEM"-Dry Powdered Form}

\section{Insecticide-To Most Leaf-Eating Insects}

One of the best vegetable insecticides in use. Specially recommended for destroying worms and insects.

Use on cabbage, cauliflower, tomato plants, cucumber vines, melon vines, currant bushes, gooseberry bushes, vegetables and flowers of all kinds attacked by leaf-eating insects.

1 lb. sifter top cartons $\$ .20$ 5 1b. packages...... .55

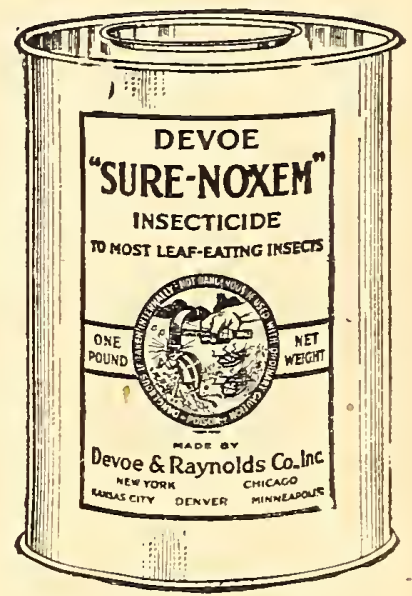

\section{LIME ANI SULPHUR SOLUTION}

\section{Guaranteed to Test 33 Degree Beaume}

A fertilizer, a sheep dip, a fungicide. It is generally conceded that the best defense against San Jose Scale and kindred enemies of the orchard, is in spraying with a solution of lime and sulphur. The experiment stations and leading orchardists now generally recommend its use. To meet the growing demand for this remedy, we are now supplynig the trade with Devoe Lime and Sulphur

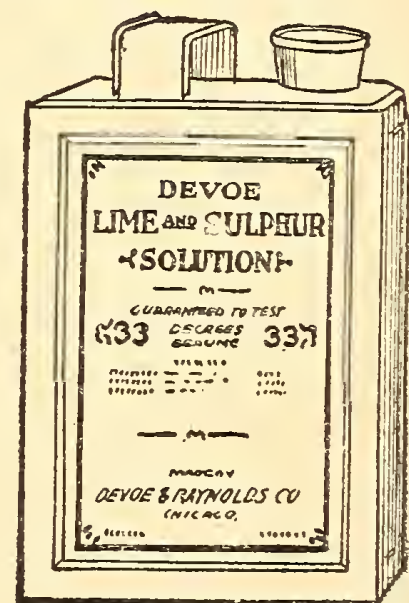
Solution.

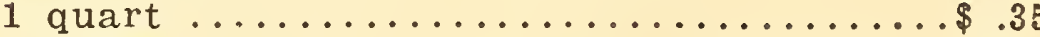

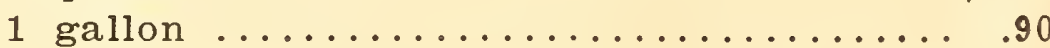

\section{BROWN AND GRAY PRUNING PAINT Ready Mixed}

This is an insecticide paint, to be used on all trees, shrubs and vines after pruning. It not only helps to heal the wound, but keeps out all moisture, prevents "bleeding" and kills insects. $1 / 4$ gal. cans ..................... \$ 40 


\section{NORTHERN GROWN SEED POTATOES}

It is a well known fact that the shortness of the season, the cool climate and congenial soll of the North develop in the potato. qualities of earliness. harriness. nroductiveness, vigor and disease resistance not found in our home grown stock. For this reason we nontract oach yoar sar our seed potatoes in those quarters.

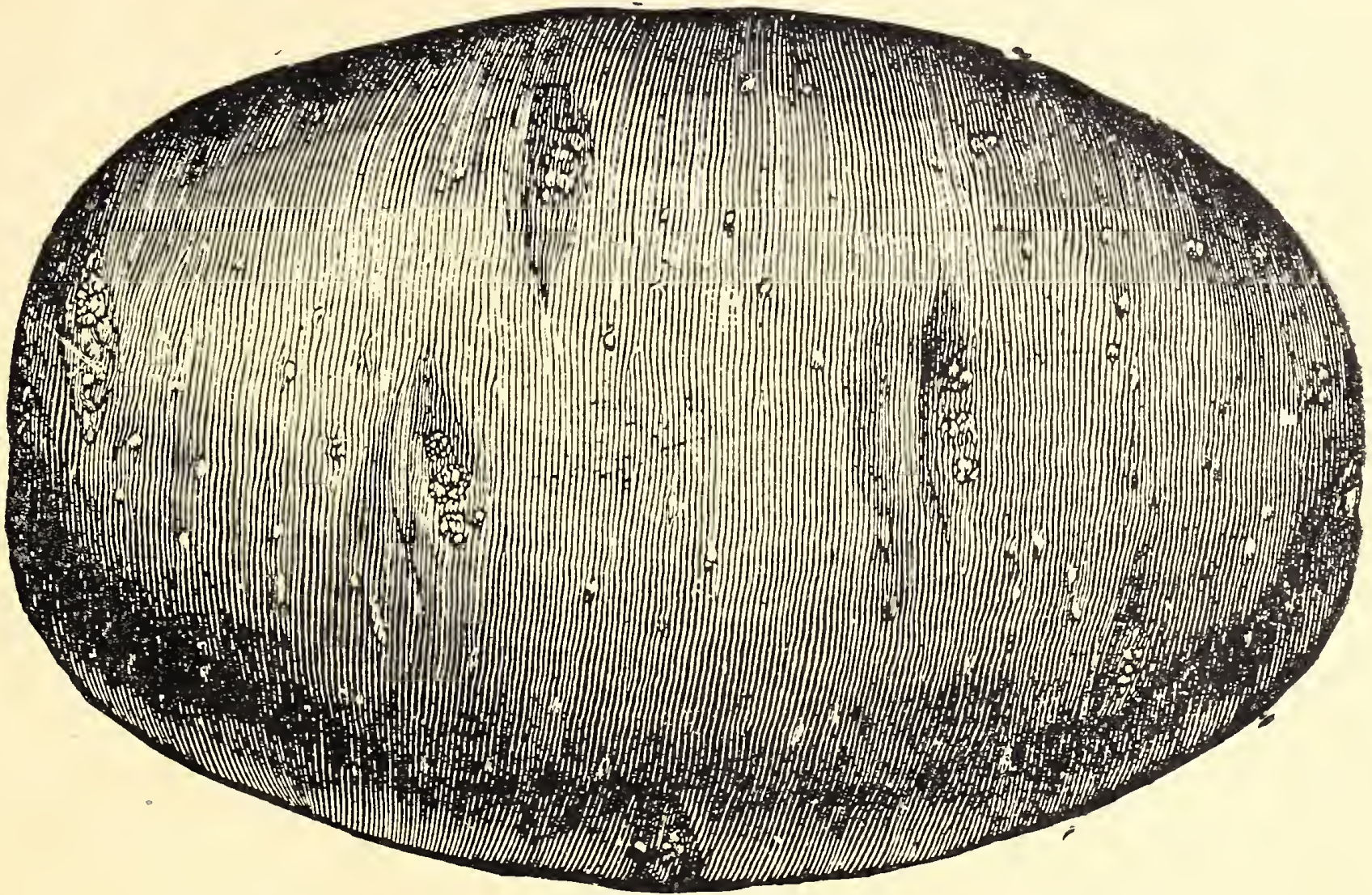

FARI.Y OHIO

EARLY OHIO. Early Ohio is the most popular potato in this country. We have more calls for it than tor any other variety. Every potato grower knows just about what it will do in his locality. It is the standard extra early the country over, and other varieties are measured by it.

We consider our stock of Ohio to be the earliest, purest and altogether the handsomest stock of Warls Ohio potatoes to be found anywhere. On these points we challenge comparison with stock from ang other source. We do not admit that its equal exists among Early Ohio potatoes. They are grown under condltions that make them cost more than common stock. They are selected with the utmost care and the result is grand, such as to delight everyone who knows and appreciates a good potato. Every one of them 1s a picture of what an Early Ohio potato should be.

EARIY SIX WEEKS. This variety is very evidently a seedling of the Early Ohio, which it resembles in very way. The potatoes grow so rapidly that under favorable circumstances in six weeks they are as large as hen's eggs, and therefore, fit for family use in six weeks from the time of planting.

RED BIISS TRIUMPF. Combines the wonderful productiveness of the old Peerless with all the good qualities of the Early Rose, is much more productive and matures its crop at least a week in advance of the Early Rose. Tubers are of medium size, round and uniform in shape, with but a very few small ones; eyes slightly depressed; color a beautiful light red. Its grea beauty, productiveness and fine quality make one of the best extra early red market varietie. Red Bliss Triumph have won their way, and w recommend them as the best early potato in the world, and the most profitable to the grower.

OMAFA gARIY ROSE. Now we offer you a new Early Rose named after our own beautiful town. It is earlier and the tubers larger than the old and popular Early Rose, and under ordinary field culture will yield 250 to 300 bushels to the acre. We know you will be more than satisfied if yo ugive this fine new sort a trial, as it is the standard early potato; rosy hlush skin; white flesh; early, productive, and of excellent flavor; a fine keeper.

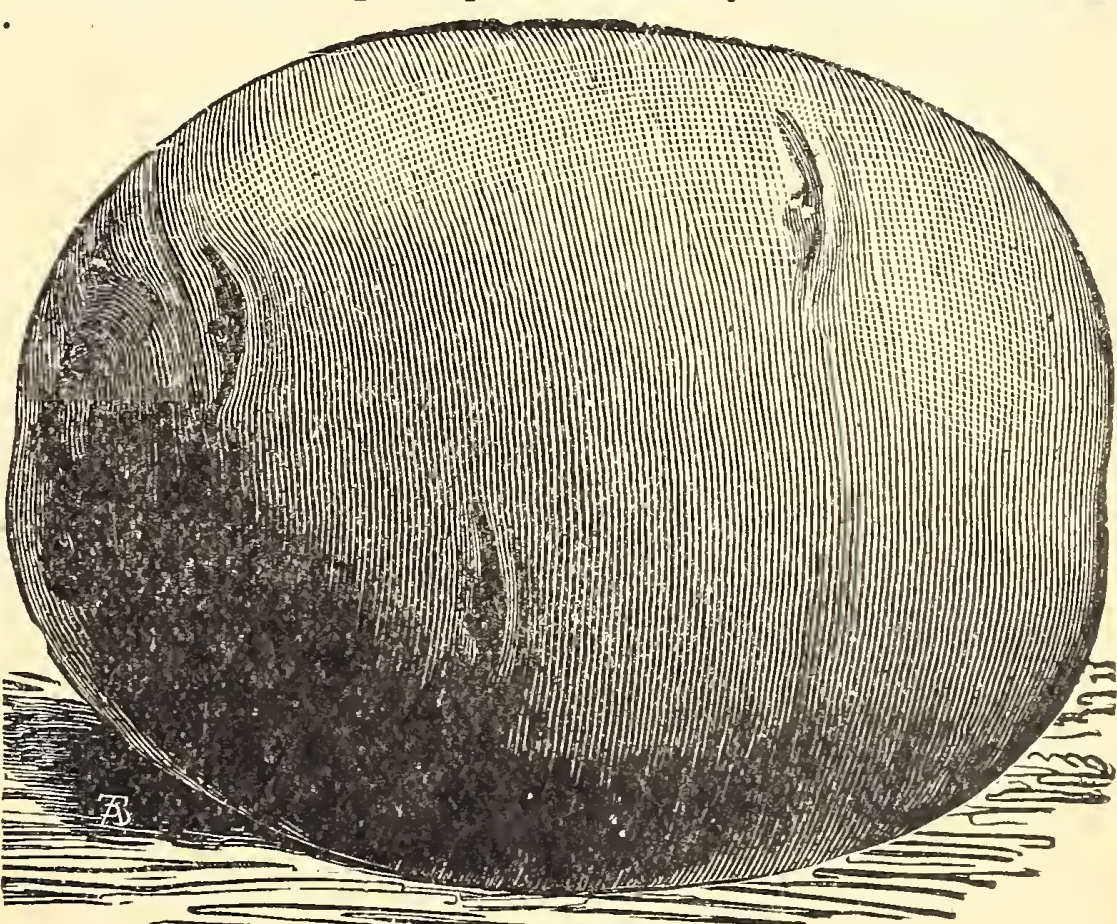

RURAI NFW YORKIR NO. 2. Well knopr now the country over, and very largely planted for a profitable main crop. It commands the highest price in all the leading markets of the country. It has a long, rather spindling vine with dark colored stalks, dark green leaves and purple blossoms; tubers nearly round, flattened, with very smooth, pure white skin, unfform in size, quite numerous in the hill, always very attractive in appearance. Our stock of Rural New Yorkers this vear is a splendid nne, and our prices are certainly very reasonable.

Prices On POTATOES-FIELD And GRASS SEEDS Subject to Market Changes 


\section{CLOVERS}

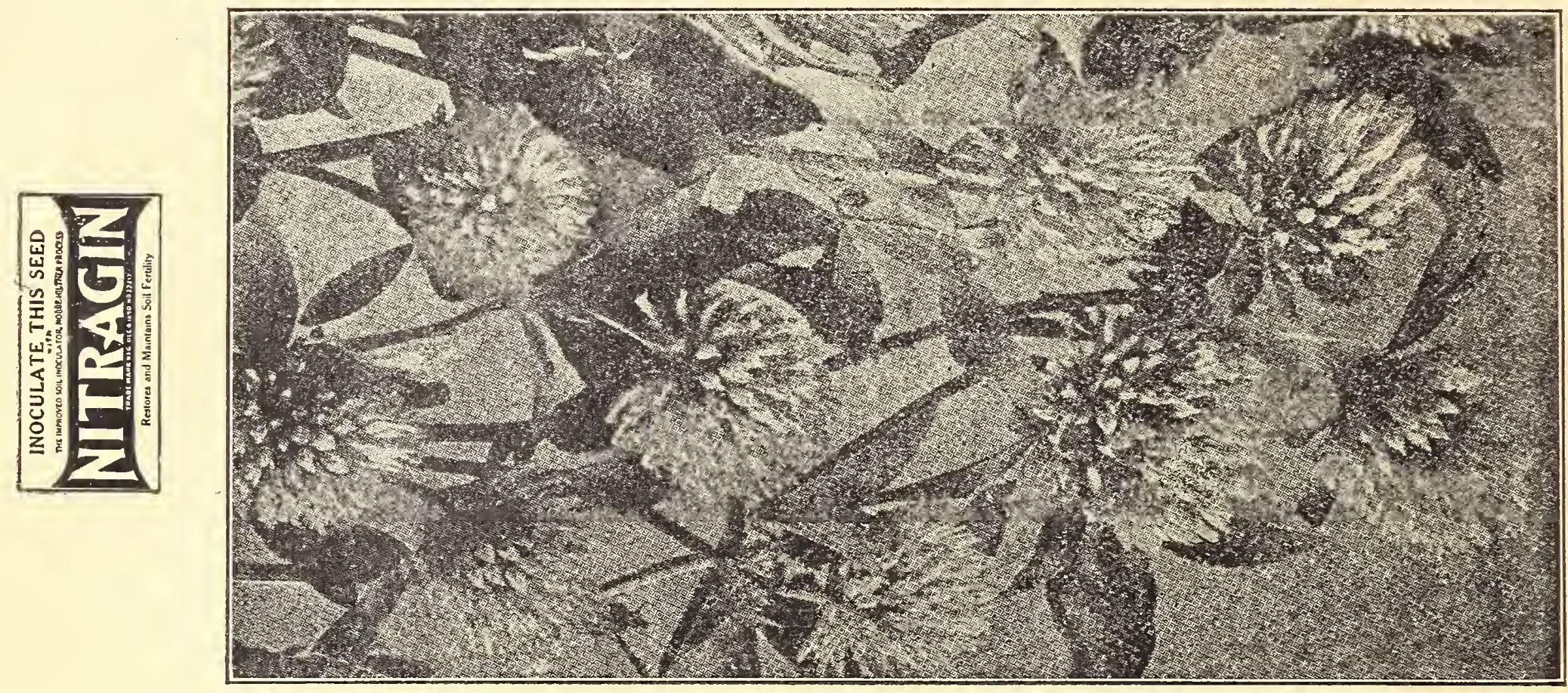

EFD CIOVPR, MEDIUM (Trifolinm pratense). This species is regarded by far the most importent of the whole genus for the practical purpose of agriculture. It makes two crops each year. The fist is usually cut when it is in blossom for hey: the last crop may be harvested for seed, cut for hay, or plowed under for manurial purposes.

Clover adds greatly to the fertility of the land on which it is grown. It does not exhaust the soil but enriches it. It pays always to buy the best grade of Clover seed which can be obtained. Even though the first cost is twice as much as cheaper seed, it will be found in the long run that inferior seed is the most expensive, not only on account of less hay or seed being produced rom it but from the eact that one's land becomes infested with weed seeds which decrease the value of the land on which they are growing.

MAMMOTE RED OR PIA VITE CIOVIR. Compared with common Red Clover, its flower, loliage and stems are of a darker color, and its seed is the product of the flower of the first crop, while the seed of the common Red Clover is the product of the flower of the second crop, and different in some other characteristics of little importance. It is valuable when sown with other orasses for mixed hay, as it ripens later than the common Red Clover, and about the time that Timothy, Orchard and other grasses ripen, thereby making the hay a much better quality. Being a very rank grower, it is coming into very general use for solling purposes. Sow twelve to firteen pounds to the acre. Weight, 60 lbs. per bushel.

AISTKE OR SWIDISE CIOVIR (Trifolium hybrdam). This clover comes from the little province of Alaska, in Sweden. It is one of the hardiest varieties known, being perennial and absolutely refuses to winter kill; it is alike capable of resisting the extreme of drouth or wet. It is a great favorite with all who have tried it. Produces annually a great quantity of herbage of excellent quality. Sow in spring or fall about elght or ten pounds per acre. Weight, 60 lbs. per bushel.

WEITY DUTCF CIOVIR (Trifolium repens) An excellen pasture clover, forming in conjunction with the Kentucky Blue Grass, the finest and most nutritious food for sheep and cows. Sow hve or six pounds to the acre. Weight, 60 lbs, per bushel.

ISPIRSTTP OR SAINFOIN (Fedysarum Onobrichis). This is a leguminous plant with stems from two to four feet long, tapering. smooth, leaves in pairs of pointed, oblong leaf lets, slightly halry on the under side, flower stalks higher than the leaves, ending in a spike of crimson or varlegated flowers, succeeded by flat, hard pods, toothed on the edges and prickly on the sides, root perennial, hardy and woody. H'lowers in July. Espersette is considered an indispensable forage plant, improving the quality of milk when fed to milch cows. It is especially adapted to dry solls, sands, gravel and barren reglons, with rainfali scarce and irrigation unabtainable. To produce a good stand sow forty to fifty pounds per acre. Weight 24 lbs. per bushel.

TEIIOW TREFOII (Medicago lapolina). An annual or biennial suitable for pasture in wet meadows or for stiff, clayey solls too poor for Red Clover. It is very useful in some sections of the country, sometimes used for hay. 15 lbs.

CRIMSON OR SCARIFT CIOVIR (Trifollum incarnatum). It is a native of southern Europe and is now largely grown in our southern states for improving the soll by turning under. The yield of fodder is immense, and, after cutting, it at once commences growing again, and continues until severe, cold, freezing weather. It grows about one foot high; the roots are nearly black leaves long; blossoms long, pointed and of a very deep red or carmine color. Makes good hay. Sow in the fall, fifteen pounds of seed per acre.

\section{For Prices, See Fnclosed Ieaflet.}

On account of the early publication of this catalogue we cannot guarantee any prices on Clover, Grass and. Field Seeds. These are market articles. and prices are subject to variation, but purchasers may depend on having them at the lowest ruling price date of order. Market prices of the day or special prices on large lots cheerfully given on application. Express or freight charges always to be pald by the purchaser, except when sufficient money is sent to repay charges. Seamless cotton bags extra at value.
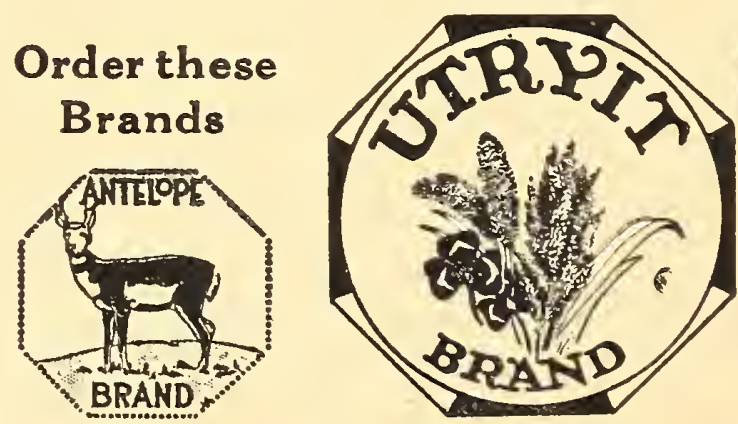

They are THE BEST

ESPERSETTE OR SAINFOIN ...

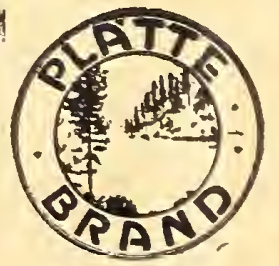

YELLOW TREFOIL

CRIMSON CIOVFR. 


\section{ALFALFA \\ Medicago Sativa. \\ THE BEST PAYING CROP ON THE FARM

Alfalfa is the imperial forage crop of America. While other field crops surpass in acreage and total yleld, in net returns per acre alfalfa is clearly in the lead.

The empire over which alfalfa rules, while not as large as that of corn or wheat, is yet the most remarkable because of the quality and riches that follow in its wake wherever this monarch goes. The time is not far distant when alfalfa will oceupy every available acre in every congenial area in America; when the demand for the crop and for its products for seed and hay at home and for meal abroad will be even greater than the supply.

Alfalfa is one of the few crops that leave the oil in better condition for having grown on it. It makes heavy soils more porous, supplies humus, brings up plant foods from lower depths and fixes nitrogen to its roots from the air to nourish later crops after the alfalfa has been plowed up.

All in all, it is the grandest forage plant on earth, and cannot be too highly recommended.

So profitable is it when once established, that overy farmer can afford to take great pains to obtain a stand. Our free Alfalfa booklet gives detalled instructions as to its handling from the preparation of the soil and sowing of the seed to the harvesting of the crop. As the best of seed is essential to the highest results, we earnestly recommend the use of our "Purity" brand. Like our other grades this seed is American grown, raised in the West and Northwest on nonirrigated land. It is absolutely free of noxious weeds and other foreign matter. It contains none but fully matured seeds and of the highest possible viability. We invite the most critical examination and the most careful analysis.

PRICES. Subject to Market Variations. ties.

Write for samples and prices on large quanti-

GrInI AIFAIRA. This is an extremely hardy variety originally brought from Germany over ifty years ago. Some of the earliest seedings are still producing heavily. On account of its productiveness and extra hardiness it has attained considerable prominence in recent years. It is however a very shy seeding sort, seldom producing more than half as large a crop of seed as ordinary alfalfa.

For Prices, See Inclosed Ieaflet.

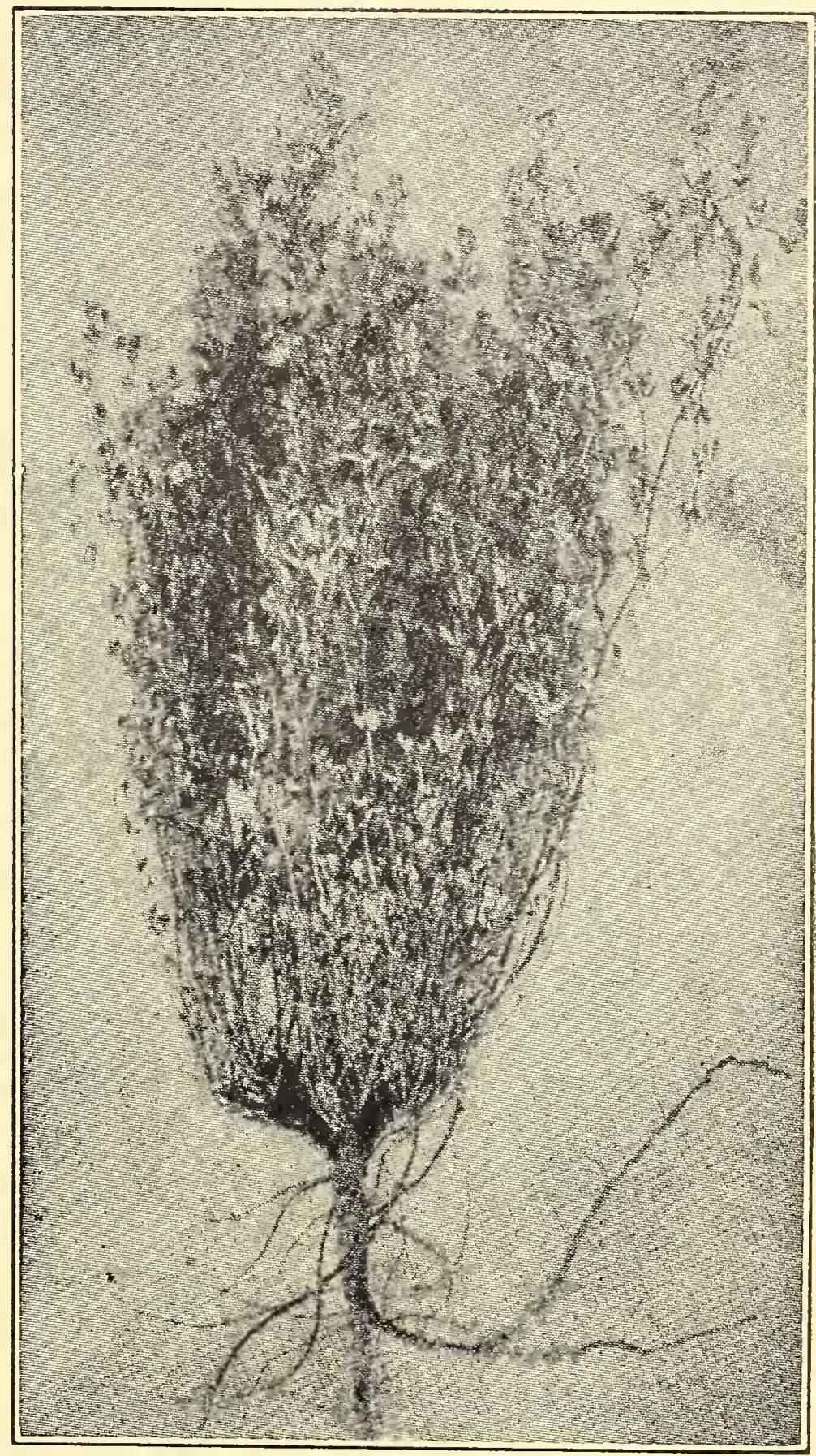

A WELL DEVELOPED PLANT OF ALFALFA

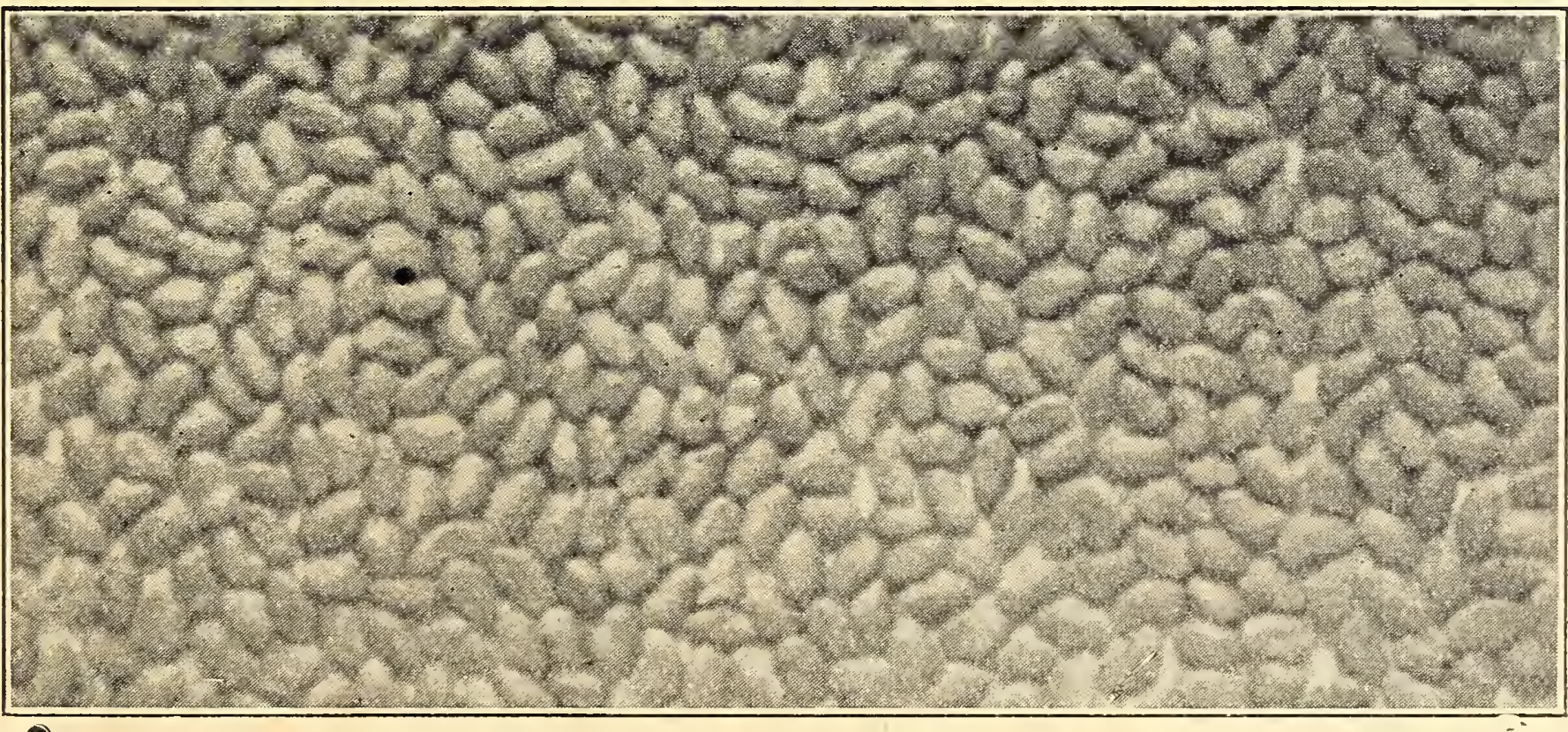

PURITY ALFALFA SEED ENLARGED

Inoculation of Alfalfa Seed is absolutely necessary for the best results-See Page 64 


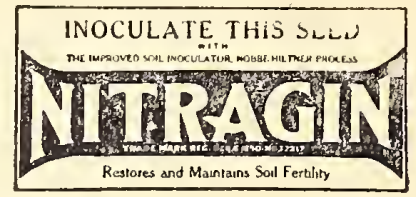

\section{Prices Subject to Market Changes}

\section{TURKESTAN ALFALFA}

The seed of Turkestan Alfalfa was first secured from Russian Turkestan by Prof. N. E. Hansen, while engaged as agricultural explorer for the Department of Agriculture at Washington, D. C.

The climate of Turkestan is not unlike that of our interior states, being far removed from the ocean and surrounded by wide expanses of dry land. The summers are very hot and long, and in many places the evaporation exceeds the quantity of molsture that has fallen during the year. Cattle raising is the main industry. The flourishing growth of this variety of alfalfa under such rigorous conditions gave every reason to believe it would prove equally valuable in this country.

Extensive trials in Western Nebraska, Montana, Wyoming and the Dakotas, in which it successfully withstood a minimum temperature of 46 degrees below zero without injury, soon proved Its hardiness.

In periods of extended drouth it has been found to greatly outyleld ordinary alfalfa. This is largely attributed to its longer and stronger tap root reaching stores of moisture beyond the depth of other alfalfa.

Not only does it endure extreme drought and cold, but excellent crops of it have been raised on strongly alkaline solls.

\section{SWEET CLOVER}

This plant from being considered a pest and legislated against, has in the past few years come to be ranked with red clover and alfalla as a food crop and soil improver.

It will grow on any soil that will grow clover or alfalfa and on many soils that will grow neither of these. It lives but two years. The irst season it makes a rapid growth and may be cut for hay or pastured in the latter part of the summer. The second year it will make two crops of hay or one of hay and a seed crop, as the second year it blossoms, bears seed and dies.

The roots are large and fleshy and penetrate deeply, into the soil, which on the death of the plant decay rapidly and furnish a large amount of humus. The same nitrogen gathering bacteria that are found on alfalfa live on the sweet clover roots making it as valuable a source of nitrogen as the former. It is invaluable for enriching a thin sandy, hard, rocky or sour soil.

It may be used freely as pasture as cattle do not bloat on it as when using alfalfa or
In this way Turkestan Alfalfa permits of a great extension of the area heretofore devoted to the cultivation of Alfalfa, and this, too, in sections where climatic conditions have almost prohibited the growing of leguminous forage crops

The plants grow strong, more leafy with slen. der and less woody stems than the common sorts, thereby making a finer and more nutritious hay.

It is generally possible to cut one more crob per season than of other sorts.

The seed we offer is imported direct from Turkestan.

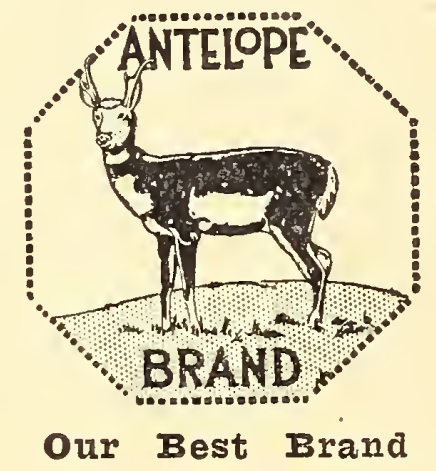

Ask for our booklet on Alfalfa and Sweet Clover, giving full directions for preparing the soil, seeding, and handling the crop.

red clover. The hay is equal to alfalfa, especially when cut before it becomes woody.

Sow 15 to 20 lbs per acre, either fall or spring but preferably in the spring.

We offer the following varieties:

WHITE SWEET OR BOKHARA CLOVER(Melilotus alba. A biennial growing $\&$ to feel high and the variety most widely used. Solid, hulled seeds. Prices subject to market changes:

Write for samples and prices on large quantities.

YELLOW SWEET CLOVER-(Mellotus offcinalis). A biennial, sumilar to the foregolng, but smaller and of more trailing manner of growth. Claimed by many to be superior for pasture.

GIANT WHITE ANNUAI OR FUBAM CIOVIR.

This is a valuabie new type discovered by frof. Hughes of the Iowa state College. It is just like the big biennial white except that it is an annual and makes its entire growth and seeds the first seaison. Seed very scarce yet.

YELLOW ANNUAL SWEET CLOVER(Melilotus Indica). 
Prices Subject to Market Changes.

\section{GRASS SEEDS}

KENTUCEY ELUE GRASS (Poa Pratengis), Agriculturally this is well called the King of all Pasture Grasses. Wherever this grass does well, generally on lime soil, land there at once commands a high price, as it becomes the animal breeder's ideal location. This grass requires some time to establish itself. For a couple of years should only be lightly grazed. Time for sowing depends on the locality. There are three principal times of sowing, in the Fall, in the early Spring and again in June. Sow three bushels (14 lbs to the bu.) per acre. This seed should never be covered, but only rolled after sowing, as the seed germinates better in the light than in the dark. Our seed this year was specially saved for us by one of the largest Kentucky growers, is almost free from foreign and chaffy matter, and our tests show a very high percentage of germination. Purchasers should beware of cheap Blue Grass, as it is sure to be light seed or else mixed with the cheaper Canadian Blue Grass.

For lawn purposes it is the standard and superior to any other sort. Under favorable soils it will withstand all variations in weather and climate. For lawns sow 50 to 75 lbs. per acre; for pasture, 30 lbs.

REODE ISIAND BENT (Agrostis Canina). Of dwarfer habit, with shorter, narrower leaves than Red Top. It makes a beautiful, close, fine turf and is one of the very best grasses for lawns in mixture with other sorts. It adapts itself to almost any soil rich and moist or dry sandy and sterile. (14 lbs. to the bushel.) Sow 50 lbs. to the acre. Ask for prices.

CREEPING BENT (Agrostis Stolonifera). The distinctive feature of this species is its compact creeping rooting stems. It is of rapid growth and spreading habit, and the stoloniferous roots form a strong enduring turf that is positively improved by constant trampling. Being of fine texture it is most valuable for lawns, putting greens, and terraces. Sow 50 lbs. to the acre.
RED TOP (Agrostis Vulgaris), A very hardy native, perennial grass, succeeding best on moist land. It accommodates itself to a variety of soils, however, even to quite dry situations, and stands our hot climate admirably. It is perhaps the most permanent grass we have and remains green for the greater part of the year. Its long trailing stems form a very close matting turf that is not affected by trampling. In chaff, per lb., 20c; $10 \mathrm{lbs.}$ $\$ 1.75 ; 100$ bs., $\$ 15.00$. Fancy seed free from chaff (sow 25 lbs. to the acre).

SWEET VERIAI (Anthroxanthum Odoratum). Valuable on account of its delicious perfume; when included in hay its aroma is imparted to other grasses, enhancing the value of the hay and making it relished by th estock. Ask for prices.

TAII MEADOW OAT GRASS (Avena Flatior). This produces an abundant supply of foliage and is valuable for pasturage on account of its early and luxuriant growth. Sow 40 lbs. to the acre

BERMUDA GRASS (Cynodon Dactylon). The most valuable grass for the southern states, as it withstands heat and drouth wonderfully well. Is valuable for hay and pasture and unsurpassed for lawns in the south, as it runs over the ground, forming a dense turf. Sow 8 lbs. per acre.

CRFSTrD DOG'S TAII (Cynosurus Cristatis). A stoloniferous perennial, forming a smooth, compact and lasting turf. It thrives best on rich moist land, but it can accommodate itself to almost any soil. Its roots penetrate deeply into the ground, which enables it to stand severe droughts. It makes a good bottom grass and is therefore valuable in mixtures for lawns and put. ting greens. It thrives well in the shade.

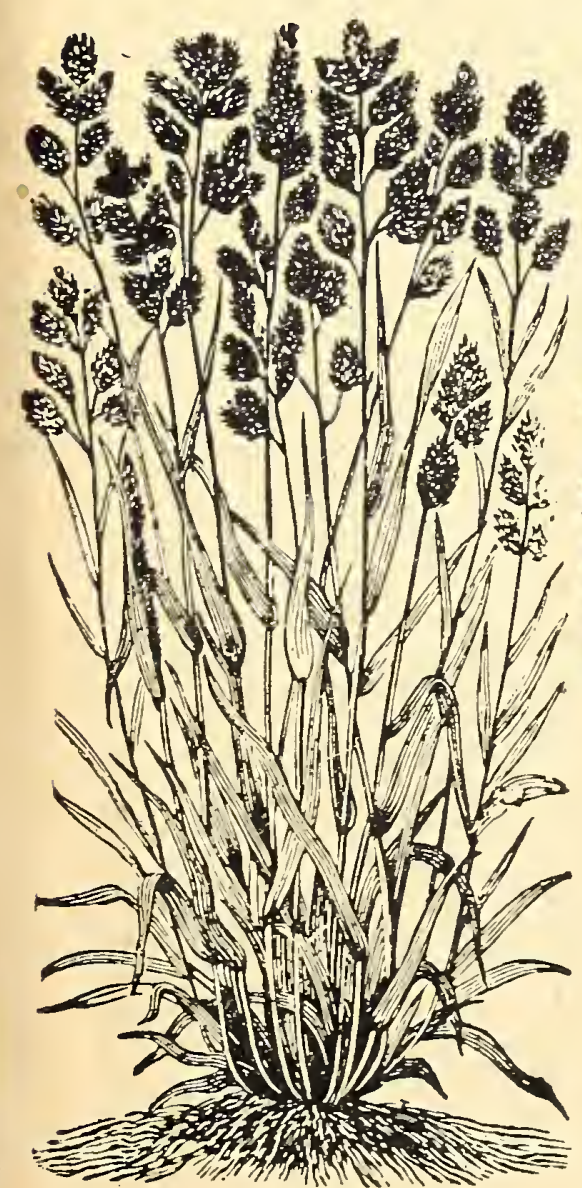

ORCHARD GRASS
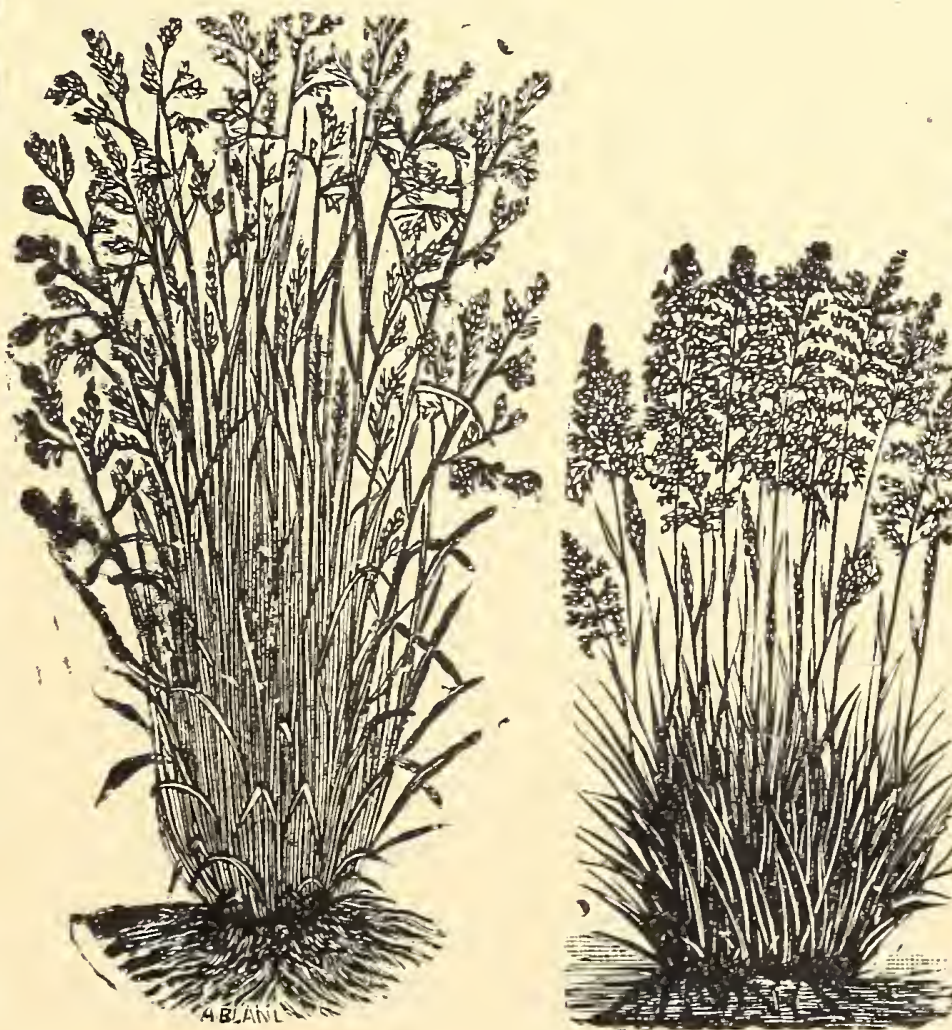

SHEEP FESCUE

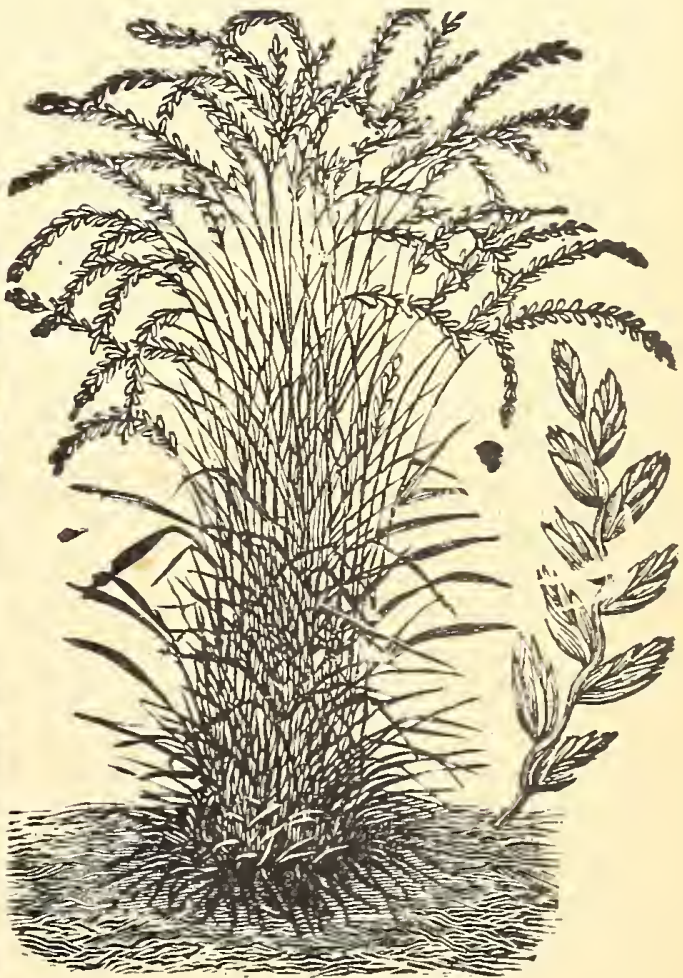

ENGLISH RYE GRASS 


\section{GRASS SEEDS}

\section{Prices Subject to Market Changes.}

ORCFARD GRASS (Dactylis Glomerata). No farm should be without a small field of Orchard Grass, as in many respects it is superior to all other grasses, stands the drouth, grows well in the shade, does well in wet and poor ground, and is splendid to prevent worn-out fields from wash. ing. This grass furnishes excellent pasturage three weeks before any other and after close graz. ing, ten days' rest is sufficient to produce another growth. Cows fed on this will produce more and richer milk than on Blue Grass. It makes a very heavy sod, and when well set remains for many years. It is especially adapted for winter graz. ing, as it remains green all the season. Sow twenty-five to thirty pounds to the acre.

FARD FESCU (Festuca Duriugcula). This grass does well in sandy pastures. Is a slender, and very tufted perennial, a dwarf form of Sheep's Fescue. A good grass for resisting drought. Of fair value as a lawn grass, and must be sown very thickly on account of its forming tufts. Sow 30 libs. to the acre. Ask for prices.

VARIOUS IIAVHD FESCUE (F. ZEeterophylla). A perennial grass, native of Europe. Of some value agriculturally as a bottom grass in pase tures. Good for both hay and pasture. For lawn purposes is quite desirable, especially for shaded places, its fine soft leaves and its creeping roots making a very good turf. Sow $40 \mathrm{lbs}$. to the acre.

SHFFP'S FFSCUI (F. OVina). Suited to light, sandy soll, and dry uplands or hillsides. It is deep rooted, and not affected by extreme drouth. Sheep are especially fond of it. Sow 35 lbs. per acre. Ask for prices.

MEADOW FESCUE OR FNGIISH BIUE GRASS (F. Pratensis). Grows two or three feet high, but never in large tufts like Orchard Grass. One of the earliest, most nutritious and productive grasses. It is especially suitable for permanent pasture: thrives well in all soils, but to best advantage on moist lands. Makes good hay and cattle thrive well on it, whether dry or in a green state. It succeeds well even in poor soll, and, as its roots penetrate the earth twelve to fifteen inches, it is not affected except by exceedingly dry weather, and is as valuable a fertilizer as Red Clover. It is one of the hardiest grasses after a good stand is secured; it will stand more freezing than any other variety. It yields an abundant crop of seed, about eight to ten bushels per acre, which can be threshed by any threshing machine. Notwithstanding its acknowledged merits, this grass has been sown only to a limited extent in this country. It is deserving of much more attention than it has heretofore received from our western farmers. Sow about twelve to eighteen pounds per acre in spring or fall.

RED OR CRFFPTA FFSCD (F. Rnbra). This is a creeping rooted species of Fescue. On account of its creeping roots, forms a compact and dur able turf, especially valuable for binding loose solls and for gravelly banks and dry slopes. An excellent bottom grass for pastures and especially for those which are quite shaded. For a lawn grass, is very good, especially for shaded spots. Sow 30 lbs. to the acre.

JOENSOI GRASS (Sorghum Ialapense). This is a species of the Sorghum family. It is an excellent grass for grazing, and contains a large percentage of saccharine matter. Sow about 25 lbs. to the acre. ASK FOR PRICES

FHGISE OR PERENNIAI RYE (I0I1UM Porenno). The hay grass of England where it position is the same as Timothy in the United States. Also does very well in this country. Good for both pasture and meadows. Molst and rich clays or loams are the solls best suited to it. The seed is heavy and very quick to start. It is a valuable lawn grass, especially where quick results are sought. Sow 50 to $60 \mathrm{lbs}$. te the acre.

ITAIIAIT RYI GRASS. In nutritive value, earliness and quickness of growth after it has been mown, it far surpasses the Perennial Rye Grass. It is, therefore, indispensable for alternate husbandry; but as it does not last over two years, it is of no use in permanent pastures. The soils best adapted to Italian Rye Grass seem to be those that are moist, fertile and tenacious, or of a medium consistency, and on such soils it is said to be one of the best grasses known to cut green, affording repeated luxuriant and nutritive crops. Sow thirty to forty lbs. to the acre.

TIMOTEY (Phleum Pratense). The most popular of all grasses for hay and the standard to which all other hay is compared. It is a perennial, doing best on a moist, tenacious, rich soll. On light soils the yield is generally scant. The best results are had by sowing Timothy with a mixture of Red Top and Clover. Timothy does not make a desirable pasture as there is little growth after being cut and tramping of stock soon destroys it. Hay should be cut just when it has stopped flowering. Quantity of seed per acre varies with the character of the soil. On heavy solls sow one-third to one-half bushel per acre; on light soils less.

\section{Ask for Prices. They are Subject to Markot Changes}

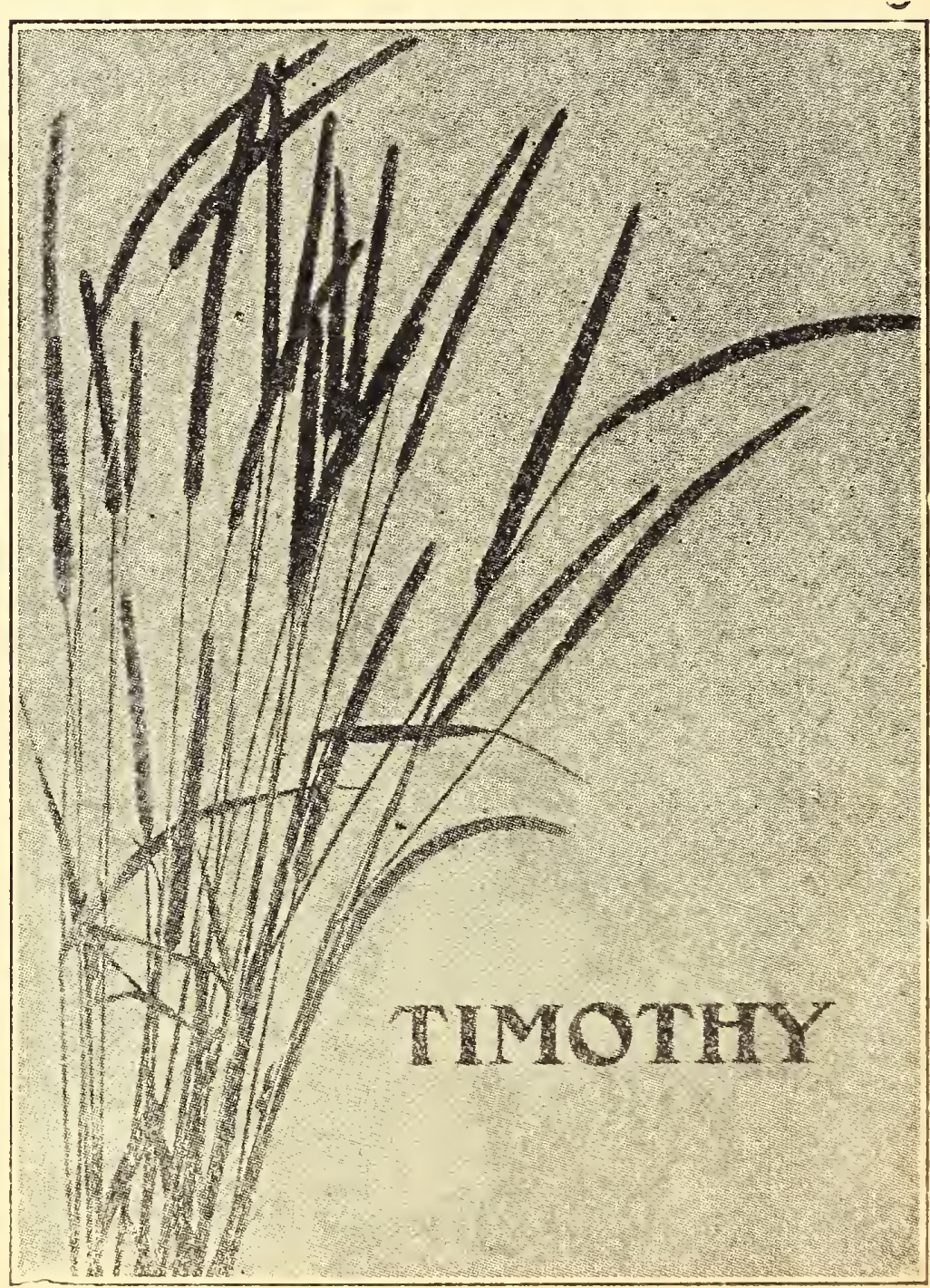


TESTED GRASS SEEDS.

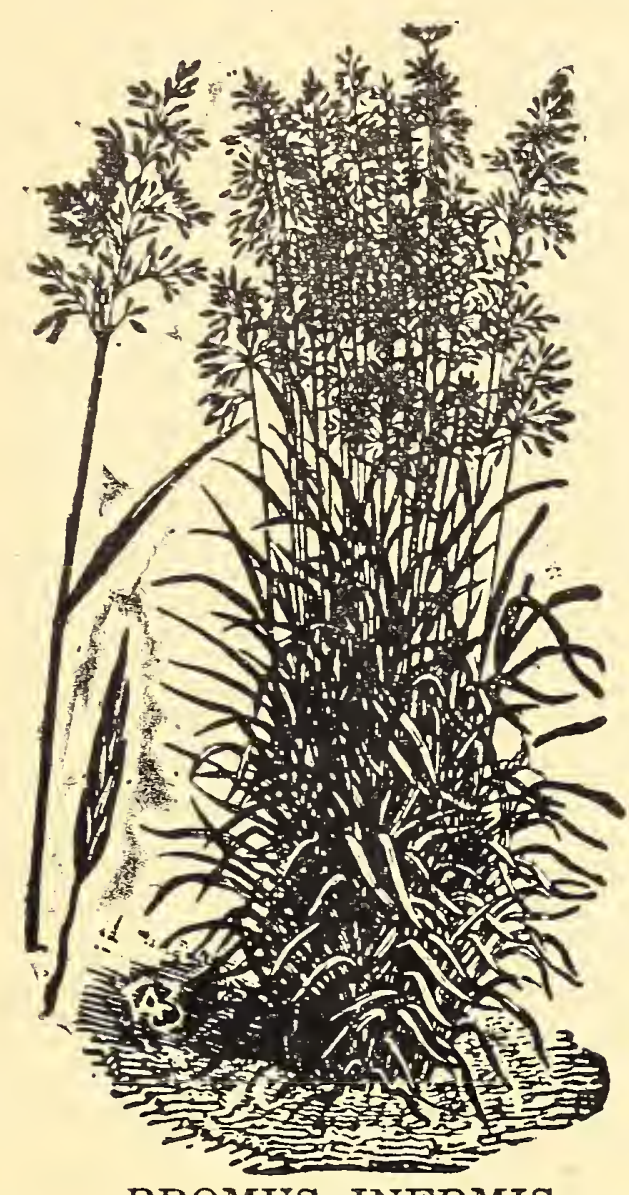

BROMUS INERMIS.

(Bromus Inermis). Is the best all around pasture grass that has ever been introduced. It is
FUNGARIAN OR AWNIMSS BBOMI GBASS a native of Hungary, but it seems to bo adapted to the prairies of the West, the cold reglons the North, and the hot plains of the South better than any other grass.

It is a strong-growing perennial grass with smooth, leafy stems, which grow from one to four feet high. It forms a tough sod, soon crowding out other common forage plants. It is very hardy. The underground stems, (root stalks) grow more rapidly in light, sandy loam but they penetrate with apparent ease the stiffest clay, and in all cases form a dense, tough sod.

It is a thoroughly established success in the West. It is a "cosmopolitan" grass, adapting itself to almost every condition of soil or climate and to any use to which grass may be put, equaling in qualicy and rivalling in yleld almost every other grass resisting extremes of temperature whether of heat or cold, profitable to sow anywhere, ibut most valuable for its wonderful power to grow under dry conditions. Its supreme adaptation for the semi-arid belt that lies west from the Rocky Mountains and extends northward from Oklahoma to the Alaskan boundaries, renders it a veritable Godsend to the people of that region.

Bromus Inermis may be sown at any time of year when ground is bare, but the preferred season for sowing in the West is in the early spring. with or without a nurse crop but is better som alone. The seed is large and light and it has been generally supposed that it could only be sown by hand, but the special "Michigan WheelbarroSeeder" handles this and other grass seeds perfectly and rapidly, and we have arranged to make special prices on this seeder to those who purchase their seed from us. Sow 28 lbs. per acre. Weight 14 lbs. per bushel.

\section{SPECIAL GRASS SEED MIXTURES}

\section{THE NERASKA SEED CO.'S SPE. CIAL GRASS MIXTURE}

This extra-choice mixture contains a large proportion of the finer and more expensive species, such as Rhode Island Bent, Crested Dog's Tall, Creeping Bent, in extra-heavy samples, bringing the welght up to $20 \mathrm{lbs}$. per bushel, and producing a turf of the closest and finest texture possible. Sow 100 ibs. per acre.

\section{LAWN RESTORING GRASS MIXTURE}

A mixture of grasses peculiarly suited to take firm hold and grow quickly on hard, worn-out or burned spots. The ibest time to re-sow them is very early in spring, but seed may also be sown in the fall from first of September to first of October. Some Lawn-restoring Grass seed should also be sown before every summer rain on thin places.

\section{FAIR GREEN AND GOLF LINK MIXTURE}

A mixture of foreign and domestic grasses that will give general satisfaction on a majority of solls. The turf formed by the grasses comprising this mixture will stand wear and tear and still retain its good appearance.

\section{PUTTING GREEN MIXTURE}

A mixture of extra fine leaved, low growing, perennial grasses that will make a close, firm and lasting turf which actually improves with tramping. Sow 60 lbs. per acre.

\section{GRASS MIXTURES FOR MEADOWS AND PASTURES}

It is a well-ascertained fact that a thicker and more prolonged growth is produced by a mixture of manj sorts of grasses than by only one or two. For every different kind and condition of soll there are grasses that are especially suitable. Some sorts do best on high ground and in dry weather; others prefer plenty of moisture. Some mature so early and others so late that from the beginning of spring antl winter sets in there is no time when one species or another is not at its best. Grass seed may be sown either early in spring or in fall from first of September to middle of October in this latitude.

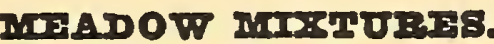

No. 1-On good land, neither too dry nor too Not. 2-On high and dry land.

No. 3-On wet late land.

\section{PABTUR2 MTRTUREB.}

No. 4-On good land, neither too dry nor too wet: No. 5 on dry land; No. 6 on wet land. 


\section{MILLETS}

\section{Prlces Subject to Market Changes.}

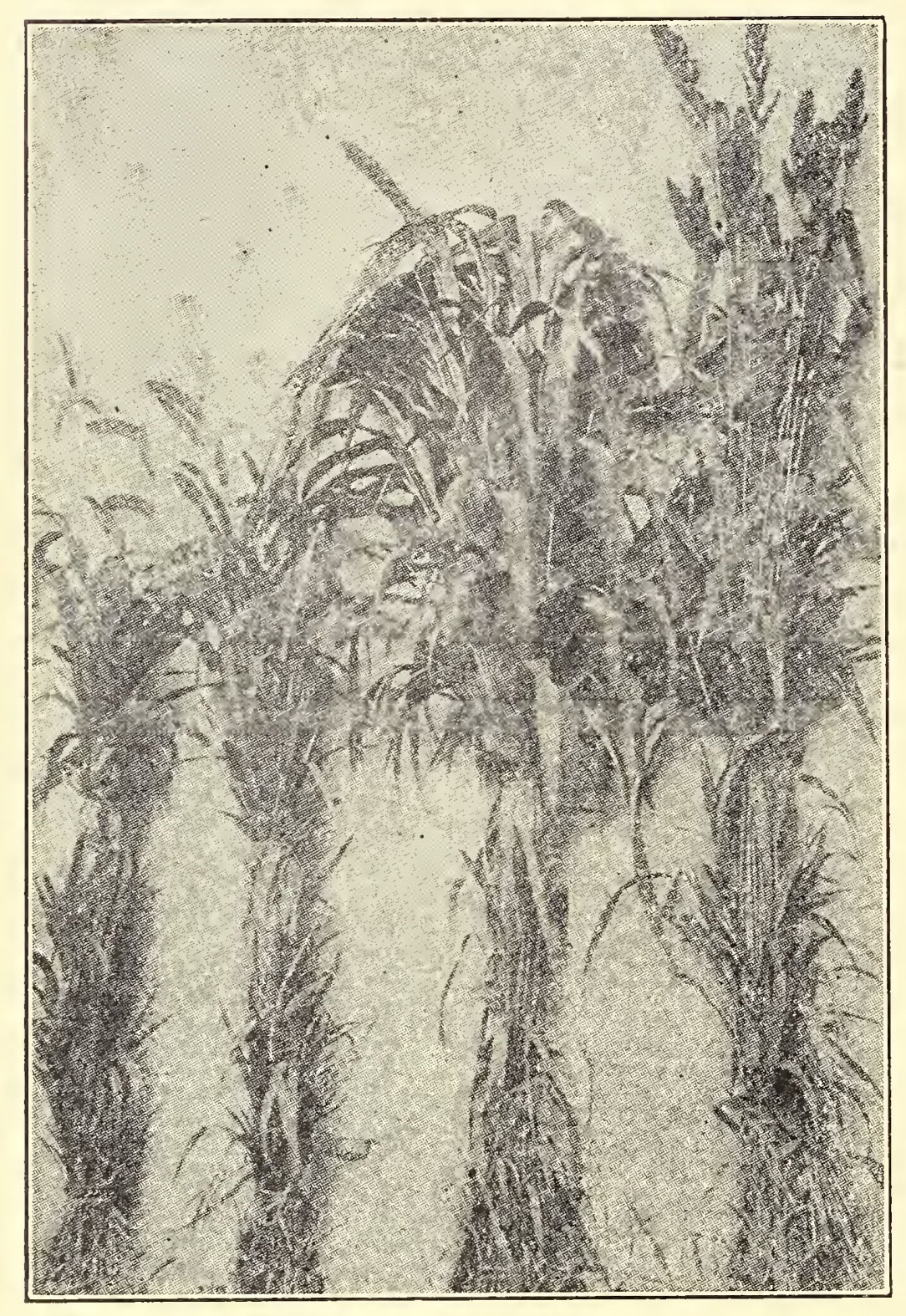

Eungarian Siberian Southern German millet millet Millot Tard

\section{THE DIFFERENCE BETWEEN GER- MAN MILLET AND COMMON MILLET}

In the North. Millet is sown almost altogether for hay, and for that purpose. Southern-grown German Millet is much better than Common Millet. It grows taller than Common Millet and that means more hay. It is finer, and that means better hay. Millet seed produced in the North, even from Southern seed, becomes eventually what we call Common Millet. Not only does the plant change in character. becoming coarser and much more dwarf. but the seed itself shows a change and is readily distinguished by those experienced in handling it.

GOLDEN (Southern Grown). Southerngrown German or Golden Millet Seed is far superior, both in quality and yield, to Western or Northern-grown seed. When properlv grown or handled, it makes an enormous yield of nutritious feed. succeeding in almost any soil. Sow in May or Tune, one bushel to the acre. Price varies with the market.
GOLDEN (Northern Grown Crop of Southern Seed). Grows three to five feet high, heads closely condensed, spikes very numerous, seed round, golden yellow, in rough sheaths. Sow thirty to fifty los. per care.

\section{Ask for Prices}

JAPANESE MILLET. All things considered, wo call this the most valuable thing in our whole list of forage plants. It has been sold under different names, as "Billion Dollar Grass," "Steel Trust Mil. let," etc., but they are all one and the same thing. We recommend it because it makes more hay than the other millets, is adapted to all sections, two crops may be cut from it and it requires less seed per acre.

Treat it the same as German Millet, except that it may be sown a little earlier. Use 20 to 30 lbs. per acre.

WHITE WONDER MILLET. Grown under semiarid conditions, this millet has proven itself to be equally as hardy and vigorous as the other varietles. It produces extraordinarily large heads and is ear. lier than German millet. The leaves are long and broad, consequently the amount of fodder produced is large and the weeds are kept from maturing. These desirable features should give White Wonder a leading place among millets.

IMANITOBA OR HOG MIIIFT. This has come to be one of the most valuable crops that the farm can raise, the seed being the richest and most valuable hog food that can be produced, while the hay is very valuable for stock. A very much prized peculiarity of the New Manitoba is that the seed ripens while the hay is yet green, when if cut promptly can be threshed for seed, while the hay makes excellent fodder after belng threshed.

TBE NEW SIBERIAN. The most wonderfully productive and satisfactory forage plant, possess. ing in a superior degree all the essential merits of any of the older sorts-exceeding them by far -besides many other points of excellence that distinguishes it and renders it a most valuable addition to the list of forages, and the claims are well founded which destines it to take frort rank, if not lead of all the rest. It is said to have come from Russia, which would, of course give it vigor and hardiness not possessed by those originating in a warm climate.

FUNGARIAN GRASS. A valuable iorage plant, withstands drouth, yields well on light soil. Sow broadcast at the rate of thirty-four to forty-eight pounds to the acre and cultivate the same as millet. Weight, 48 pounds per bu.

COMMON MIILET (Panicum Milliacenm). Very early; grows two or three feet high; follage broad. Sow in drills broadcast from May 1 to Jure 20 , if for seed, or until the last of July for aay. For grain sow in drills; use 30 to 50 lbs. per acre. Tf for hay sow broadcast, 50 lbs. per acre. Weight, 50 lbs. per bu. 
Price subject to Market Changes.

\section{RAPE -TRUE DWARF ESSEX}

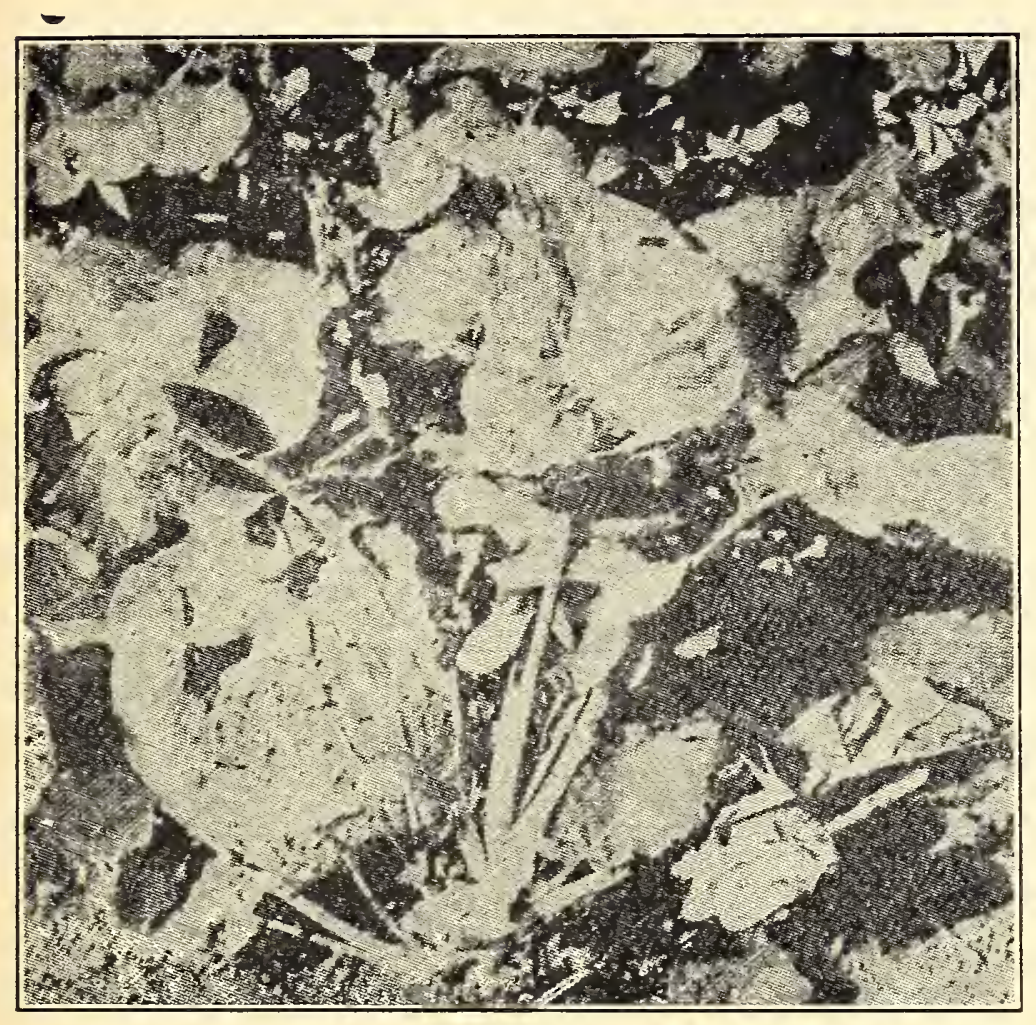

RAPE-DWARF ESSEX

DWARF ESSEX RAPE. This is an ideal sheep feed, easily grown; perfectly hardy and possesses remarkable fattening properties. One acre will pasture 36 head of sheep two months and lambs will make a gain of 8 to 12 pounds a month. Pigs and cattle are also very fond of it. The plant

\section{BROOM CORN}

WIISON'S IMPROVED TENNESSEF FVERASTING, This Broom Corn grows about 8 to 10 feet high, stands up well and is entirely free from crooked brush. The fibre is long and fine and will always command the highest price.

MISSOURI EVERGREEN. Is a favorite of Kansas, Nebraska and Missouri.

\section{BUCKWHEAT}

Buckwheat should be sown about the middle of June, broadcast, at the rate of from one to three oecks per acre.

JAPANESE. An early maturing variety with dark brown seeds, or large size, making it a profitable sort to raise.

SIIVIR HUII. This variety is a decided improvement over the common sort. The hulls are light gray and very thin. Much preferred by millers as there is less waste and it produces a winter flour. Remains in bloom for long time.

COMmon. The old. well known sort.

\section{PEANUTS}

Peanuts can be cultivated as early as potatoes. They yield largely and are a paying crop. Planted in April they ripen in August.

MAMMOTH VIRGINIA. is a rank grower and should have heavy manuring as well as high cultivation. Any corn soll will grow rape. A good crop will furnish at least twelve tons of green food per acre and its nutritive value is nearly twice that of clover.

This plant may be grown successfully in the following ways:

First-In the early spring to provide pasturo for sheep and swine.

Second-In June or July on well prepared land to provide pasture for sheep. The crop will be ready to feed at a season when it is most needed.

Third-Along with grain, using two lbs. of seed per acre to provide pasture for sheep after harvesting.

Fourth-Along with peas, oats, clover seed, to provide pasture for sheep, and to get a "catch" of clover.

Fifth-Along with corn drilled in broadcast to provide pasture for sheep.

Sixth-In corn, sowing the seed with the last cultivation given to the corn.

Seventh-Along with rye sown in August in sheep pastures.

When the Rape is sown broadcast, 5 lbs. of seed per acre will suffice. When sown in rows, say 30 inches apart, and cultivated, from one to two lbs, will be enough. The cost of sowing an acre is less than with any other forage plant.

A director of one of the Agricultural Experiment Stations says: "We had one-half an acre of Rape, which gave an actual yield of nine and three-fourths tons, or at the rate of ninteen and one-half tons per acre."

\section{FLAX SEED}

PRIMOST OR MINATSOTA NO. 25. A variety selected and improved by the Minnesota Experiment Station. Field tests at the station for three years showed yields averaging 3.4 bushels $\mathrm{per}$ acre more than the average of three commercial varieties. In addition to its superior yielding abillty it produces longer stems. Write for prices.

RUSSIAN FIAX. The variety principally used in the flax growing sections, but which wo expect to be superseded by the No. 25. Our stocks were. especially selected for large heavy seed and freedom from disease.

\section{FMTIR.}

\section{(Triticum Spelta.)}

This grain, wrongly called speltz, was intro. duced from Europe and has been profitably grown in this country for more than twenty years with increasing popularity. Its ability to resist drought, attacks of rust and smut and damage by wet weather during harvest, and the fact that it is adapted to semi-arid as well as more humid conditions and to a variety of soils make it a gen. eral purpose crop as regards soil and climate. It is readily eaten by all kinds of stock, being especially adapted to milch cows. Mixed with oats as a ration for horses, it replaces corn.

BIACE OR WINTER FMMER. An improved strain originated by selection of individual plants which proved their hardy quality. Used for stock feeding the same as barley or oats, it is of value where these grains do not do well. Ripens earlier than oats, yields better and furnishes fall and winter pasture. 


\section{Nits?}

More and more Cow Peas are planted every year more and more their great as the plant is a legume, ad through the agency of the nitrogen producing acteris on its roots adds this valuable plant food a much cheaper than it is possible to the allent hay: should be cut and cured the same as ellent hay; should be cut and cured the same as Clover: then the stubble with its new growth may be turned under as a fertilizer. Kaffir corn sown with Cow Peas holds the

For those in the North who have had poor success with Cow Peas, we suggest the plant must cess warm, almost sandy soll. Where never have a before, the best results may be had in grown before, the best results may fist as for drlling the seed and cultivating at nist as ior neld beans the best of things unless kept down.

BIACI COW PIAS. This variety, whlle a litle later than Whippoorwill, produces more growth of follage and is consequently better for cutting

\section{CANADA FIELD PEAS}

"Peas could be made to bring more nitrogen to the solls of this country every year than is now the solls of this con purchased annually, by the larmers at a cost partment of Agriculture.

For the Northern States there is no crop of reater value than Fleld Peas and none is more srealected, which can only be attributed to a lack of knowledge as to its merits. Whether for rodder, in mixture with oats, sown at the rate of wo bushels each per acre, or the Peas sown lone at the rate of three bushels per acre for alowing under, there is no crop that we can so strongly recommend for more extended culture.

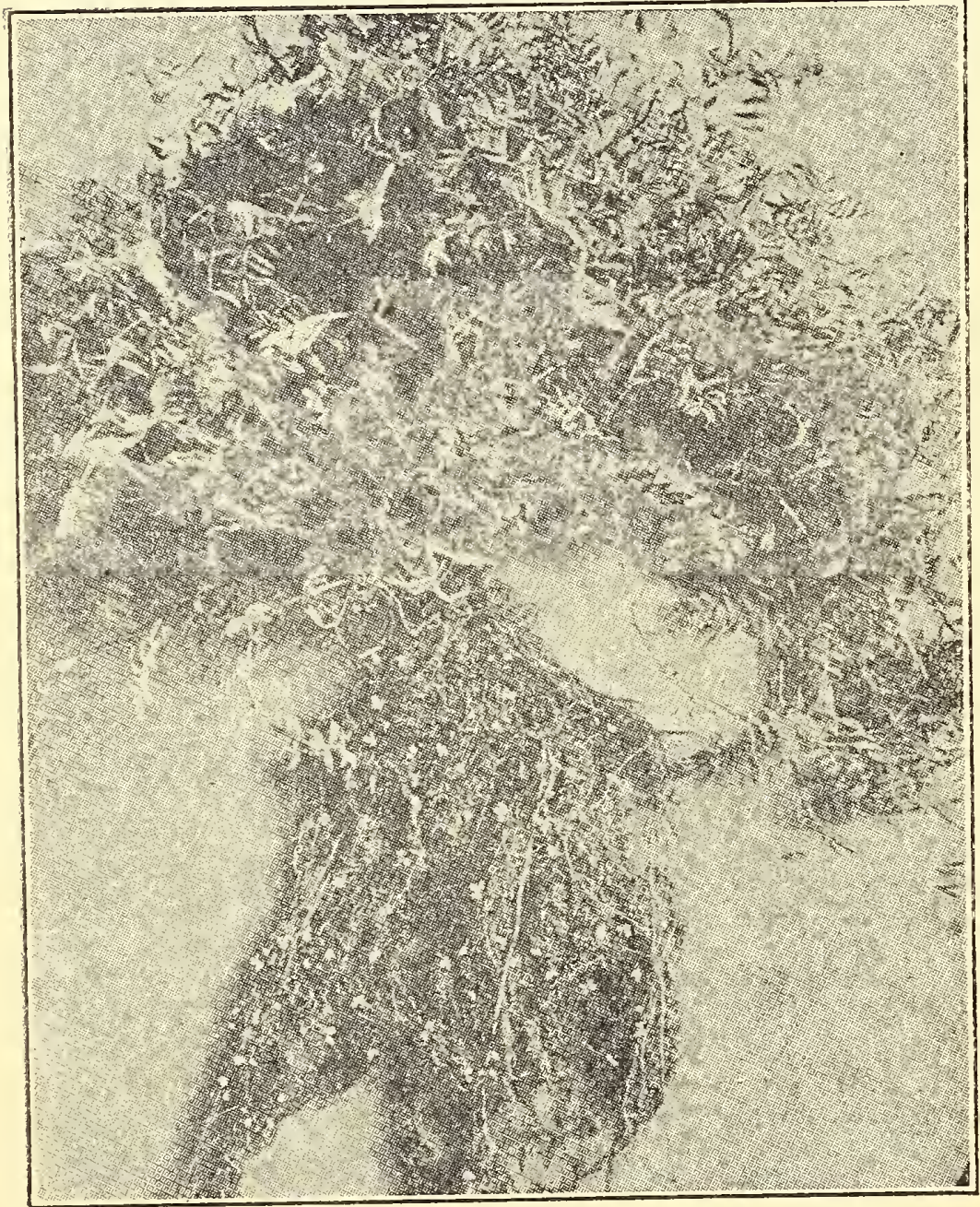

PIANT OF SAND OR WINTERVETCH-NOTE THE GREAT NUMBER OF NITROGEN TUBERCLES ON ROOTS and as a soil improver. It makes large yleld of peas and is very popular in the latitude of Kentucky.

WHIPPOORWIII. A favorite early bunchgrowing variety, has brown speckled seed.

This variety is a prime favorite in the North and West on account of its early maturity and habit of growth.

CIAY. This makes an enormous and remarkable growth of vines but requires the full grow. ing season to make its crop. In yield and growth of vines it surpasses any of the varletles of Cow Peas. This variety should be planted in May.

INEW gRA. An early maturing variety, which has proved very popular and satisfactory. It is upright-growing, quick to mature, and remarkably prolific of peas. The vines cure easily, making splendid dry forage. The seed are smaller in size than the ordinary Cow Pea, so that it does not require as many to seed an acre from three-fourths to one bushel per acre will give ample seeding.

\section{CANADA FIELD PEAS AND OATS FOR FODDER}

For Dairy Cows and Iogs, Equal to Corn, and sis Weeks zarlier.

These make a fodder and hay which double the production of milk. They should be sown in March or early April, two bushels of peas and two bushels of oats to the acre. The peas should be sown first and plowed under about four inches deep; the oats then sown and harrowed in. They will be ready for cutting about the latter end of June, when the oats are in milk and the pods formed on the peas. Farmers who have never sown this crop will be surprised at its large yield. It is a nutritious food and relished by all kinds of stock. This crop also makes an excellent soll improver when turned under like cow peas as described above.

FIFID PEAS. White Canada Field.

\section{SAND OR WINTER VETCH}

Too much cannot be said regarding the value of this Vetch for forage and fertilizing purposes. It succeeds and produces good crops on poor sandy soils as well as on good lands, growing to a height of 4 to 5 feet. It is perfectly hardy throughout the United States, remaining green all winter. If sown in the spring, it can be sown alone or mixed with oats, spring rye or barley. If sown during August or September, winter rye serves as a good support. The root growth is very extensive from the beginning, and makes quantities of nitrogen tubercles, thus giving it very valuable fertilizing properties. For plowing under as a soiling crop we belleve it is superior to Crimson Clover or Cow Peas. As a forage piant it will yield $11 / 2$ to 4 tons per acre. It is excellent for dairy stock and poultry pasturage, being exceedingly nutritious, eaten with relish and may be fed safely to all kinds of stock. Sow 50 to 60 pounds per acre with $1 / 2$ bushel rye, oats or barley.

\section{SPRING VETCHES, OR TARES}

A species of very small pea, grown extensively in England and Canada for stock feeding. The seed is also largely used for pigeon feed. Culture same as for field peas. 


\section{OATS}

IIIrCOIIr. After many years' trial, has proved Itself one of the most popular oats yet introduced. We call attention to the following special points of excellence: First-It is very productive, having in all instances yielded more to the acre than any other sort grown in the same locality, in one case having yielded 174 bushels from a single bushel of seed. Second-It is very early. Third -It has thus far proved itself rust-proof. Fourth -It stands up better than any other sort. Fifth -It is best for feeding on account of its thin hull, heaviness and soft nib. Sixth-It is best for oatmeal or grinding.

SWFDISE SFIECT OATS. A pedigree variety introduced from Russia. This was in the cereal exhibit made by the United States Department of Agriculture at the late St. Louis Exposition. Now well acclimatized, weighs from 36 to 40 pounds per measured bushel. The straw is coarse, noted for its stiffness and power to withstand lodging. The grains are pure white in color, large, thick and plump, making a very handsome appearance. The heads are large, upright and bushy, they are also nearly all meat, the hull being exceedingly thin, making them especially valuable as a feeding oat. Their great root development enables them to resist drought better than most other kinds. They are quite early and less liable to smut and rust than most any other sort.

\section{SEED BARLEY}

MALSEUEY. Is one of the very best sixrowed barleys grown, with kernels plumper and fuller than the best Scotch Barley, while for malting it is the very best known. It is early in ripening, which helps it to fill well, thus it is always plump.

WHITE HULIESS. A valuable variety, has large heads, plump kernels, both hulless and beardless and looks like large white wheat. Is two or three weels earlier than any other barley and an immense jlelder. Stools wonderfully; sow only 1H bushels per acre.

\section{WINTER OR SPRING RYE}

RYE, WINTER. Our stock is No. 1 Grade.

RYE, SPRING. This grain is often planted by farmers especially for the paper makers, who prefer it to any other.

\section{WINTER WHEAT}

We have growing now the following varieties: Red Turkey, Fulcaster, Highgrade, Nigger, New Monarch, Golden Cross, Red Clawson, Jones Winter Fife and others. Will be pleased to quote prices next fall in time for sowing.
KHERSON OATS. Brought to America in 1900 by the University of Nebraska from the provinco of Kherson, Russia, with the idea of procuring on oat that would be hardy, a good yielder, and yet extra early. Small lots were sent out to farmers all over Nebraska and the tests have proven that the oats far exceed their highest expectation as to earliness, amount of yleld, and ability to withstand our heavy winds and not lodge.

We have secured our stock seed from a grower in Douglas county who received his start from one of these small lots furnished him four years ago by the Experimental Station. The Kherson Oats when ripe are a beautiful yellow color, have fine, large sprangled or full heads which trequently contain more than 100 seeds. The stalk is stiff and does not lodge or rust. It has broad leaves, many of which are three-quarters of an inch wide; they extend to the roots and are so pliable that they stay on even through threshing. Unlike most heavy yielders these oats have a large grain with a very thin hull. Under Iav. orable conditions they have yielded as high as 95 bushels to the acre in Nebraska. At the University Experimental Farm they made 74 bushels to the acre.

\section{SPRING WHEAT}

VFIVIT CEAFF BIUE STEM. This a remarkable semi-hard spring Wheat, yielding extremely well in soft wheat states. No soft wheat will give better satisfaction than Volvet Chat.

MACARONI SPRING WEEAT. New variety for the semi-arid district. "The thorough establishment of this new wheat industry will be the greatest benefit to agriculture in the semi-arid plains A million or more acres can thus be given to profitable wheat raising which, on account of drouth heretofore have been entirely idle or less profitably employed. In a lew years the result ought to be the addition of thirty to fifty million bushels to the annual wheat production of the great plains alone."

In the West, especially the semi-arid sections, the conditions are ideal for producing this wheat.

MARQUIS. Is a week to ten days earlier, yields 5 to 10 bushels per acre more and has higher milling and baking tests than any other hare spring wheat.

This wheat is a cross between the Red Fife and Red Calcutta, an early, hard, red wheat from India. The plant is similar in appearance to Red Fife, but the heads as a rule are heavier and the straw shorter, thus making it less liable to lodge. The grain is flinty dark red and short and thick, giving it a distinctive appearance. The heads are beardless and the chaff smooth and yellow.

The seed we offer is Canadian grown, free from smut and exceptionally pure. 


\section{Prices Subject to Market Changes} SORGHUM

\section{NON-3ACCHARINE VARIETIES}

SFAIIU. A Non-Saccharine Sorghum from India, where it is extensively cultivated under the name of "Shallu."

It grows quite tall and stools from the root, a single grain making 3 to 6 stalks. The heads are large, similar to broom corn, and well flled with lump round white seeds. It makes excellent feed for horses and cattle and is unexcelled for chickens. While more a grain than a forage crop, it furnishes good fodder.

Sow in rows three feet apart, three to five pounds of seed per acre. For fodder, sow half to one bushel either broadcast or in drills. Give it a trial.

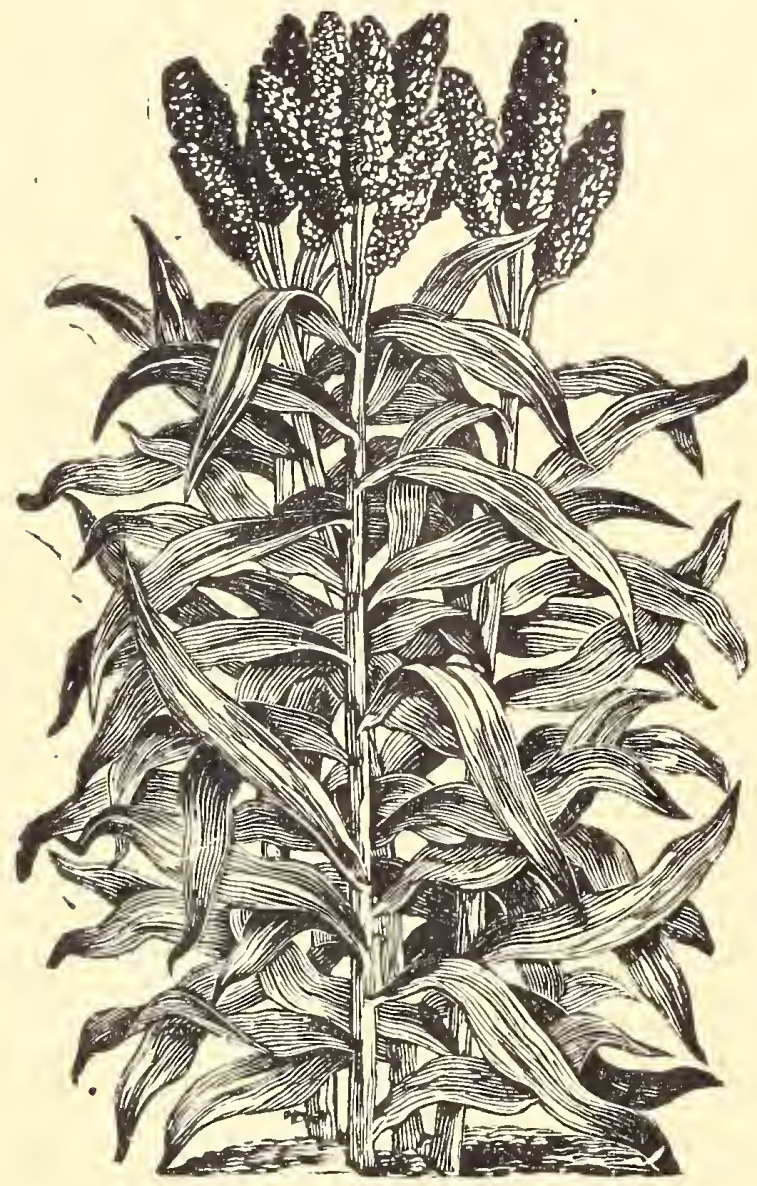

KAFFIR CORN

WIITE KAFIIR COIN. It grows from four to five feet high, making a straight, upright growth. It has a stalky stem, with enormous wide leaves. The stalk keeps green and are brittle and juicy, not hardening like other varieties of sorghum, making excellent fodder either green or dried, which is highly relished by cattle, horses and sheep. The seed heads form at the top of each stalk, and as soon as these show the grain well, the joints next below the top send up shoots which yield the second seed heads. For the grain sow in rows three feet apart, three to five pounds of seed to the acre. For lodder sow one-half to one bushel, either broadcast or in drills.

RED KAFII CORN. This grows taller than the white; the stalks are slenderer, but more juicy and very leafy. 'The heads are long, slender, compact and grow erect; they measure from one to two feet. The seed is red, smaller than that of the white, and rather hard and urittle. It does well on poor land and yields well. It rlpens a little earlier than the white variety, and yields much heavier. It is highly recommended by the Kansas Agrionltural College at Manhattan

SCHROCK IRAFTIR. An early drouth resisting half saccherine variety.
YELLOW MILO MAIZE-(Milo). Growth is tal1, 9 to 12 reet, stooling from the ground. It sends out shoots also from the joints. Seed heads grow to great size, often weighing $\%$ of a pound, sometimes a full pound, after ripening. On account of the branching habits this grain should be planted in rows 4 to 5 feet apart, and 2 to 3 feet in the drill, or 2 plants in a hill. 3 to 5 feet apart.

FrTfRIA-Introduced in the United States in 1907 from Egypt. Feterita has been grown for several years in Oklahoma and found to be one of the greatest drouth resistant and heavy yielding plants grown in that section. Grower raised 30 to 55 bushels per acre last season.

Feterita has a white kernel, somewhat larger than Kafir and heads a little shorter; grows 4 to 6 feet tall and matures about 40 days earlier than Kafir. Should be planted in rows $3 \frac{1 / 2}{2}$ feet apart and dropped 6 to 8 inches apart in the rows. It should not be planted as close as Kafir, because when the plant is about 6 inches high, it puts out from 4 to 10 sucker plants, each plant maturing a large head of grain. The heads of Feterita grows upright and has the same feeding value for all kinds of stock or poultry that Kafir or Milo has.

Feterita should be cultivated the same as Corn Kafir or Milo: should be cut and bound the same as Kafir and fed out in bundles to get the best re. sultis.

SUDAN GRASS. This, one of the most remark. able forage crops known, was introduced by the U. S. Department of Agriculture, from Egypt, in 1909 and tested at various state experiment stations. These tests show it to be adapted to the semi-arid regions as well as those enjoying ample rainfall.

It is a tall annual grass normally growing from 6 to 10 feet high and producing from 25 to 100 stalks to each plant. The yield of hay is reported from 3 to 6 tons per acre.

All kinds of stock eat it readily and it makes a profitable ensilage.

In arid districts it is usually planted in row 3 feet apart, using 2 to 4 lbs. of seed per acre if a seed crop is desired. If forage is wanted. plant 8 to 12 lbs. per acre in 18-inch drills. Sown broadcast in regions of ample rainfall, 15 to 20 lbs. per acre is required.

\section{SACCHARINE VARIETIES}

Sorghum (or sugar cane) has attracted general attention. In the West, its great merit is not at all appreciated, and we wish to call the attention of farmers everwhere to the great value of Sorghum as a pasture and fodder crop, and to the particular advantage to be gained by growing it. Sorghum may be made to furnish the principal provender for cattle and horses from August until the following spring. As a summer pasture for sheep, a wide field is likely to be opened up by it. As a soiling food for swine it is most excellent, and the seed furnishes a splendid food for fowls. It can be profitably growi everywhere, from the extreme north to the extreme south, and on any ground adapted to the growth of corn. It grows right along through the severest and most prolonged drouths, so that a good yield may be expected from suitable soils in any seasons after the plants have secured a good start.

FARII AMBIR CANE. This popular and well known variety is the earliest.

EARIY ORAITGE CANE. A well known vari. ety, well adapted for the south. 


\section{PEDIGREE SEED CORN}

\section{THE COST OF GOOD SEED AND ITS VALUE}

The extra expense on growing our seed corn is not the largest item in its cost. Once harvested it must be carefully hand picked three times before shelling. After picking and grading it is seldom that more than 15 per cent of the crop is left for seed. Hence it is apparent that our margin of profit is not large. A bushel of corn will plant six to eight acres. It usually costs less than $35 \mathrm{c}$ to plant one acre.

If the yield is increased one bushel to the acre the cost of good seed corn has been paid. Prof. Holden shows a difference in yield due to the seed planted of from twenty to eighty bushels per acre. This difference in yleld is the difference between planting common crib corn and planting our selected, graded, hand picked, pedigree seed corn, with a history of big yields behind it.

IMPROVFD IFAMITG. The Leaming, in its various types, is probably more largely plantea, now, both in northern and southern states, than any other field corn known. The ears are very handsome, of good size, with fair-sized grain of a deep orange color and small, red cob. The stalks grow to medium size (not large), with few suckers, slender and leafy, making most excellent fodder, and usually produce two good ears to a stalk. It husks and shells easily; ripens in from 90 to 100 days, and never falls to make a good crop. Over 100 bushels per acre is not an unusual crop for this corn. It is also adapted to a greater variety of solls than many, producing unusually well on light land.

RFID'S THIIOW DINT. The great prizewinning Show Corn. Now the most popular and most uniformly distinct type of Yellow Dent for Northern Central Nebraska (in fact for the whole state) and similar corn belts. Fifty years of careful selection has resulted in remarkable evenness in appearance of ears. It is more accurately described as follows: Ear 9 to 10 inches long, 7 inches around, 18 to 24 rows with narrow space hetween rows; deep grains with small cob well qlled at butt and tip. We offer a very choice sesetion of seed grown from pedigree seed selections for years-our stock. This strain is slightly rough, tapering very slightly; cob medium. It has won first prizes at most all state fairs and corn shows. It was grown with the view of breeding it up to an average size of ear eliminatIng barren and inferior stalks which produce only nubblns, and increasing the amount of oil and protein in the corn for feed purposes. We believe in this corn we have corn in which two bushels wlll do as much towards developing farm animals as with an ordinary corn, $2 \frac{1}{2}$ bu. will do. It ripens in 120 days easily.

IOWA GOID MIIP. This variety has every. where received the most cordial endorsement as one of the best and most profitable varieties. It is early, ripening in about 100 days, ears of goo size, color a bright golden yellow; grain is very deep, cob small, and therefore dries out very quickly as soon as ripe. Seventy pounds of ear corn will make about sixty pounds of shelled corn; and in hauling to market it welghs out considerably more to the wagon load than common varleties.

\section{Ask For Prices.}

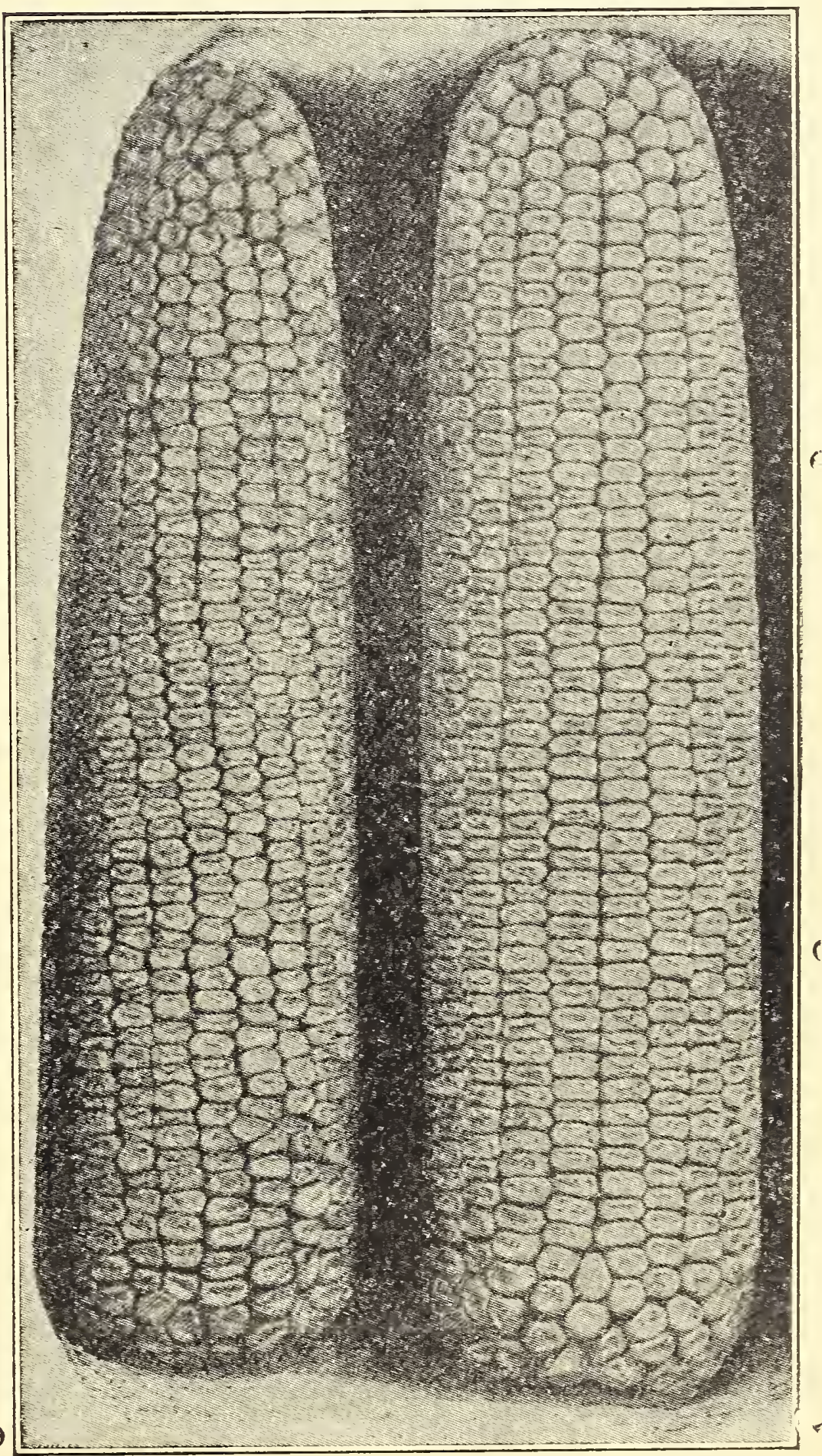

IMPROVED LEAMING REID'S YELLOW DENT

PRIDE OF THE NORTH (16-ROWed, Maturen in 90 days). Ears 8 to 10 inches in length and $11 / 4$ inches in diameter. Kernels closely set, above medium size, long, narrow, thin, of deep orange color, shading to pale yellow at the tip. Cob very small and red. In a test, 70 pounds of ears, not selected and but imperfectly dried, produced $601 / 4$ pounds of shelled corn and only $91 / 4$ pounds of cobs, instead of 14 pounds, the usual proportion. Stalks about medium height-6 to 8 feet. 
"IDEAL" SPRAYING OUTFIT

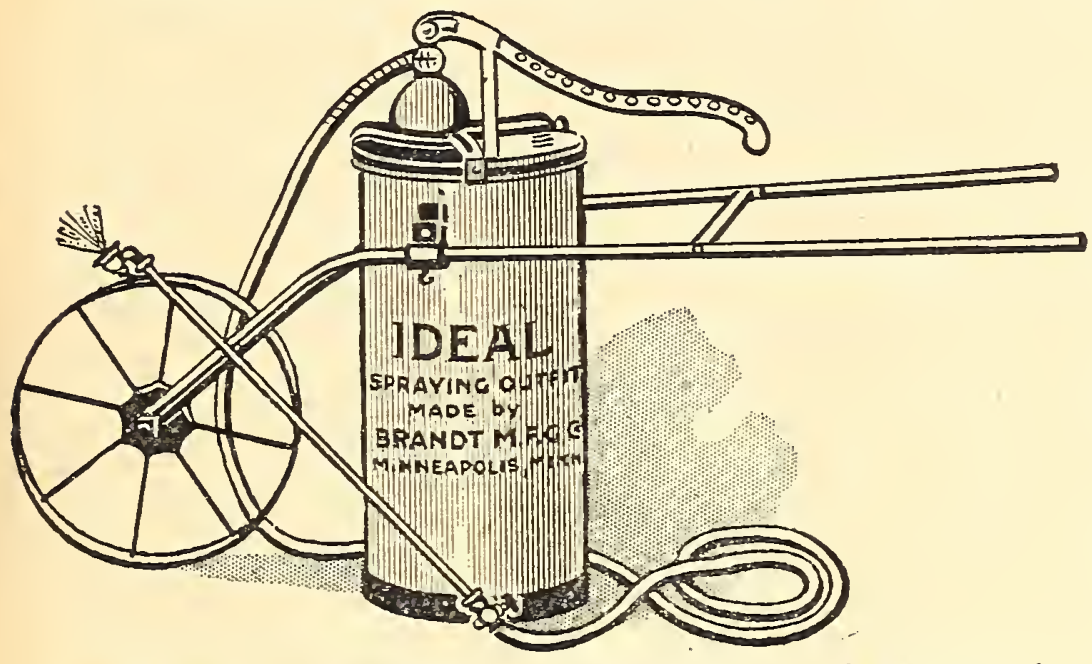

Designed to meet the requirements of the smal! gardener and fruit grower. The tank holds 15 gallons and is mounted so liquid will not slop or spill, and is easy to wheel and handle. A pressure of 151 ibs. can be easily maintained. Equipsure of $150 \mathrm{lhs}$. can be easily maintained. ten feet pipe extension ( 3 pieces): one brass shutoff cock; one Brandt Ideal nozzle.

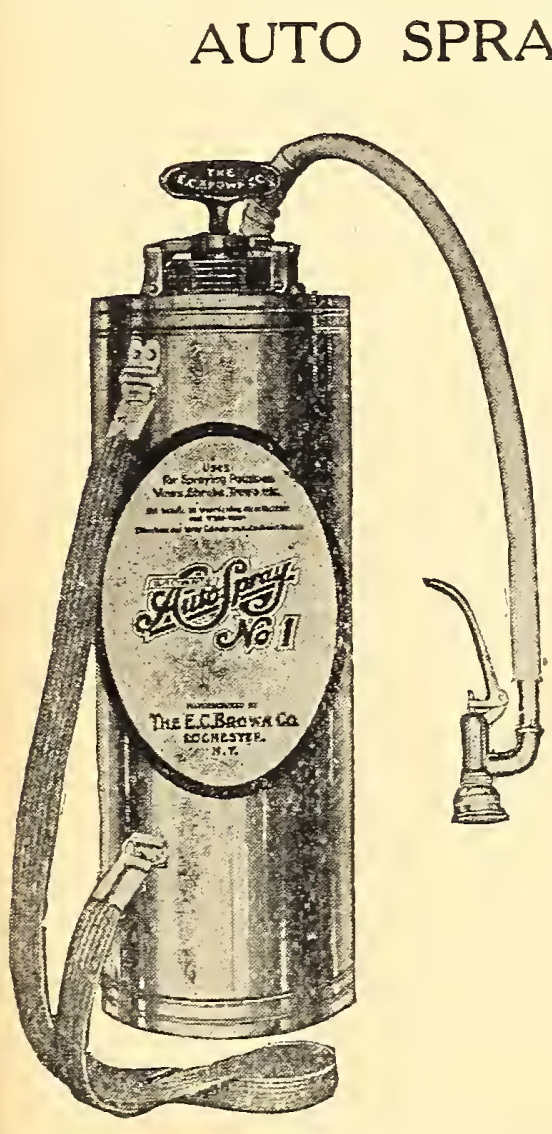

NO. 1

Works automatically for 6 to $15 \mathrm{~min}$ utes, according to the nozzle opening. It may be started in 15 seconds by a few strokes of the plunger.

The "Auto Spray" has a capacity of four gallons, and when properly ch a rged contains three gallons of solution and one gallon compressed air. Eight to $t$ w e l vie strokes of the plunger will compress the air, and two pumpings will discharge the entire contents. Three gallons of solution or one charge will easily cover one-half acre of potatose or other similar crop.

\section{StimUplanT \\ Makes a \\ Wonder Garden}

\section{AUTO SPRAY NO.28}

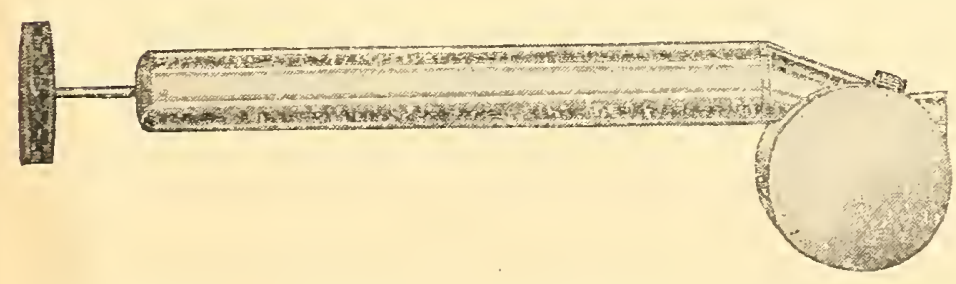

A general purpose sprayer, for farm, stable or garden uses. Handles fly-oils, bug poisons and disinfectants. Has large powerful pump. $50 \mathrm{c}$.

Solution tank is made from heavy IX tin and is so constructed that the sprayer will not tip over when filling. Capacity one quart.

\section{YOUR SPRAYING PROBLEMS}

THE STANDARD SPRAYER.

If you have several hundred trees, buy the STANDARD and 20 or 30 feet of hose; put a barrel on a sled or drag and you are ready to spray from 300 to 500 trees a day.

If you grow potatoes, you need the Knapsack and Extension. Ten acres a day is the easy capacity of this outfit.

One man with a STANDARD will actually accomplish more work than three men with an ordinary outfit costing from $\$ 35.00$ to $\$ 20.00$.

The STANDARD SPRAY PUMP is not merely a "bucket" pump. It is a Bucket, Barrel or Knapsack pump as desired.

If you have only 20 or 30 trees to spray the STANDARD with the usual $3^{*}$ foot length of hose and a bucket will do your work nicely.

If you keep chickens, you will want the Curved Extension. This helps in spraying around roosts, nests and corners of the chicken house.

The STANDARD is very efficient for whitewashvehicles, veterinary injections, dampening tobacco, ing, disinfecting live stock, fire protection, washing pumping out boats, etc., etcs.

\section{SPRAY-TABS}

\section{CONTINUOUS SPRAYER NO. 25}

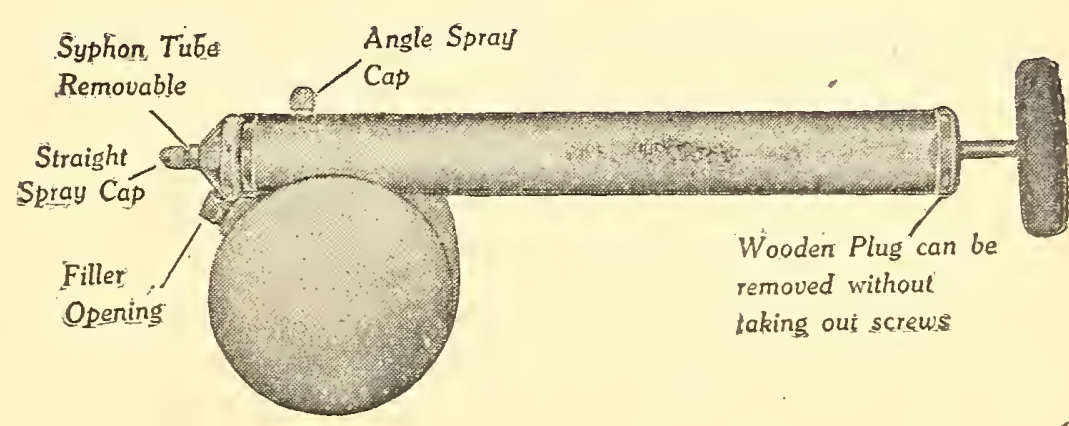

As the name implies, is so constructed that it not only sprays on the downward stroke of the plunger, but also when it is drawn back, thus causing a continuous mist-like spray.

Two spray caps-one straight, the other at an angle for reaching under leaves or spraying directly down. Construction of tank permits the sprayer to be operated at any angle and it will not tip over when fllling.

By a convenient arrangement the wooden plug that guides the handle can be taken out of the pump cylinder without removing any scrows. 
AUTO SPRAY NO. 21

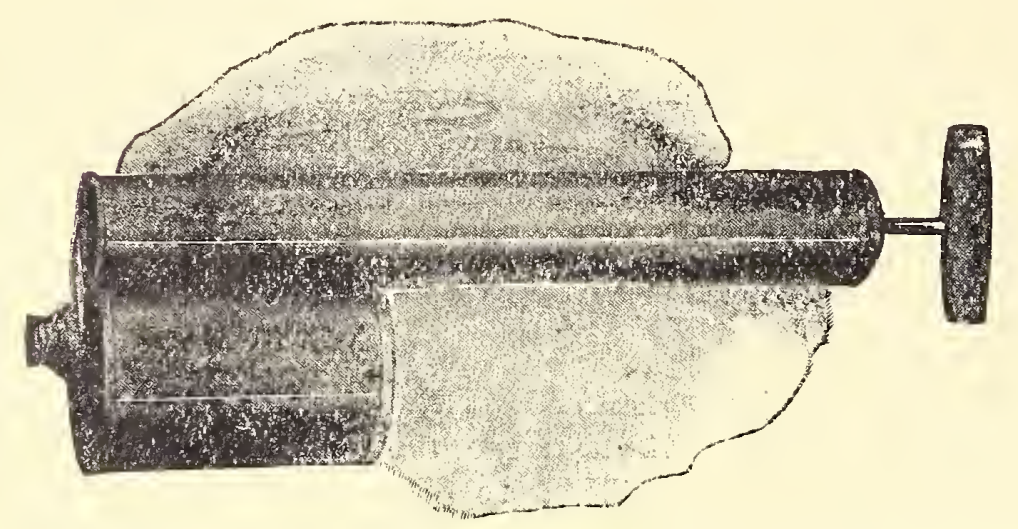

Similar to the No. 22 sprayer but has capacity of one pint.

\section{AUTO SPRAY NO. 20}

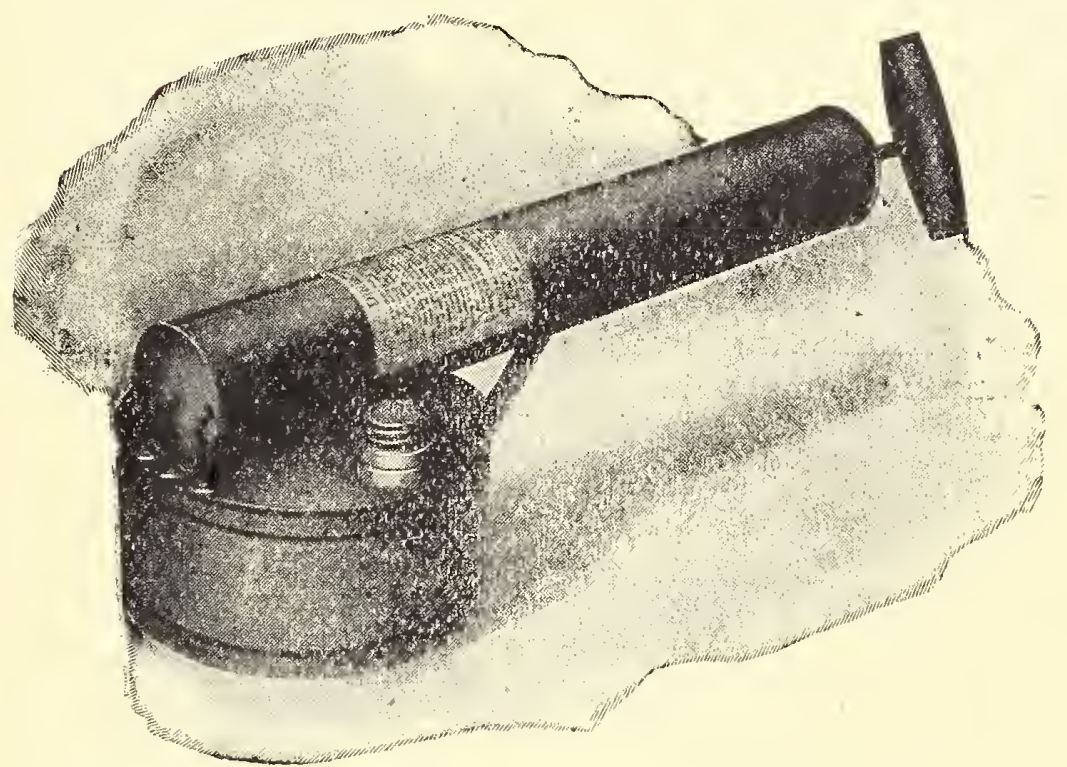

This Sprayer has a one-quart galvanized reservoir and three spray jets. The pump is two inches in diameter, which insures ample pressure.

\section{STIM-0:-PLANT}

LIGHTNING DRY POWDER DUSTER

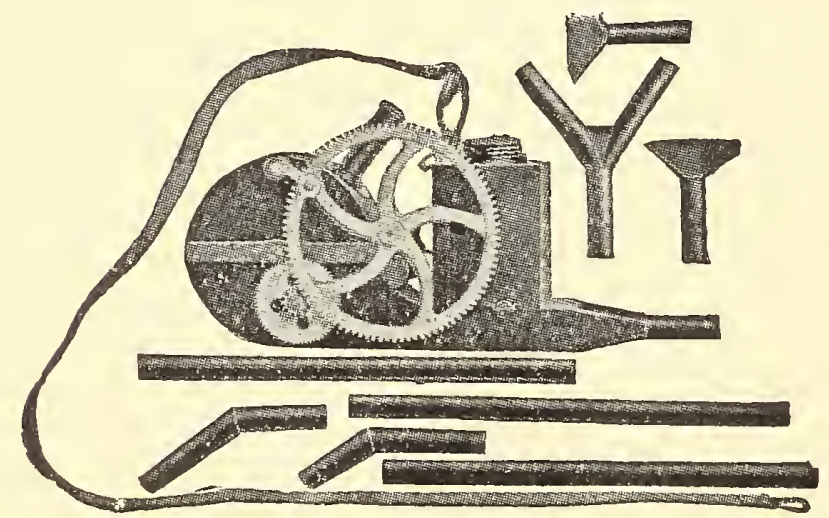

The best dry powder gun; will distribute any ary insecticides and fungicides. Will do as much work in a day as a horse power sprayer. Dusts two rowis at once.

NO. 12 HAND DRY POWDER DUSTER. Holds about 3 pints. For applying dry paris green, hellebore, Bug Death, etc.
AUTO-SPRAY NO. 5

\section{tis Double Acting}

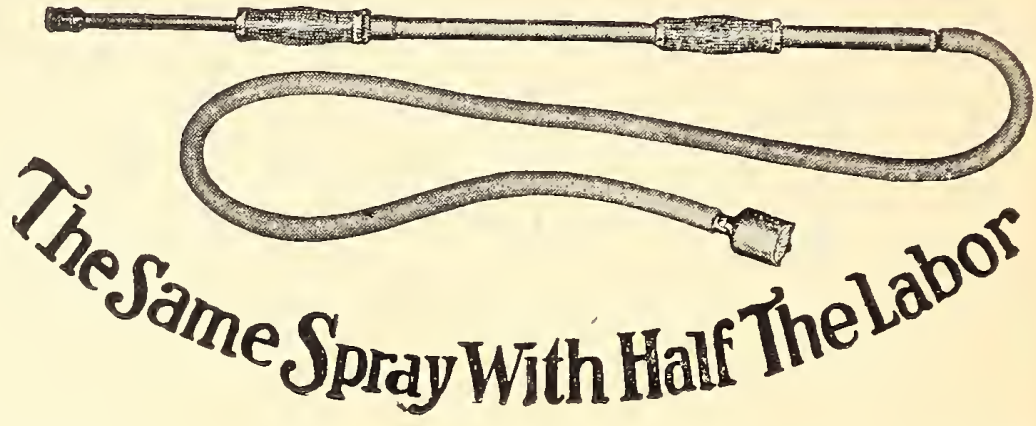

The pump is made entirely of brass. It has two ball valves so arranged that they may be instantly cleaned. The threads are all cut, not rolled, so that there is no chance for leakage. Pump is double acting and will generate a pressure of $180 \mathrm{lbs}$.

No. 26 Brass Bucket Spray Pump, adjustable to any size pail; maintains a constant pressure of from 50 to $100 \mathrm{lbs}$.

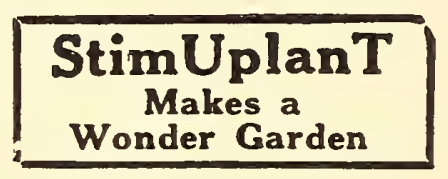

\section{THE HUDSON SPECIAL}

\section{COMPRESSED AIR SPRAYER}

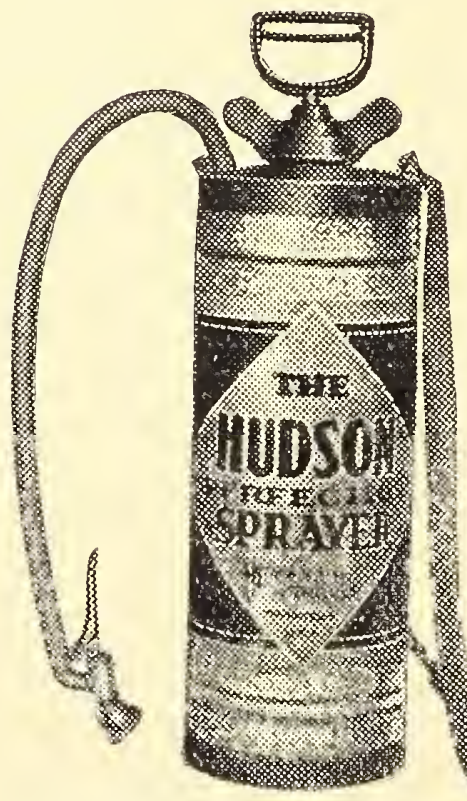

We positively guarantee this Sprayer to operate at 60 to $80 \mathrm{lbs}$. pressure. It is made of heavier materials throughout than the average compressed air sprayer. The liquid is discharged in a fine penetrating fog like mist, which not only sprays the tops of the foilage but turns the leaves over by sheer pressure, reaching the underside where most insects are located.

Tank is furnished in galvanized steel, a powerful all brass pump screws into top of tank. thus eliminating any possible leakage of air. Furnished complete with three feet discharge hose, spray nozzle, shut-off cock and shoulder strap.

FOR SPRAYING MATERIALS

SEE PAGES 39 AND 40 

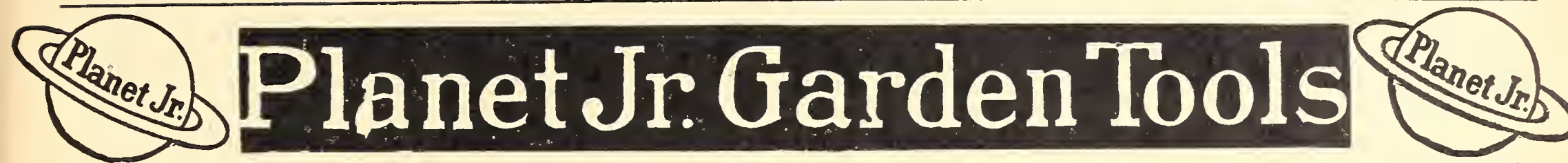

The New "PLANET JR" Catalogue is the ha ndsomest, best, and most instructive book ever issued on a similar subject. Full of little point $s$ that bring profit. Full of true and handsome lilustrations. We mail it free to any address on applieation.

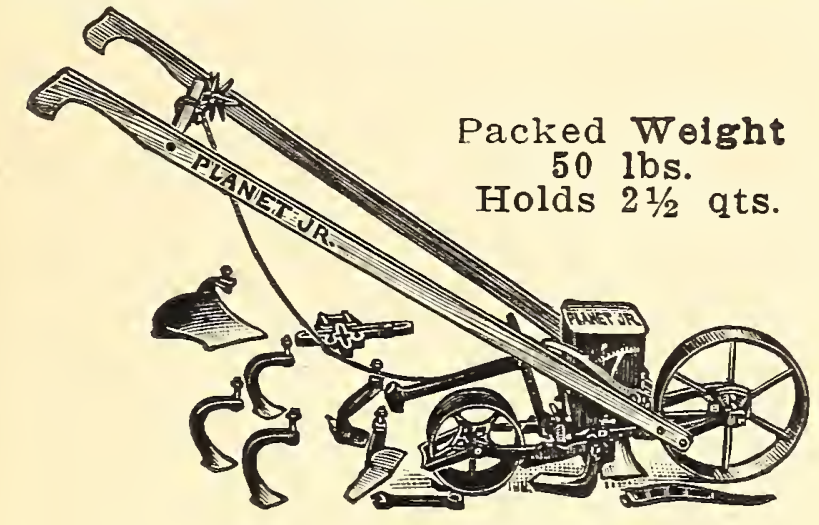

No. 4 PLANET JR. COMBINED HILL AND DRILL SEEDER, WHEEL HOE, CULTIVATOR AND PLOW

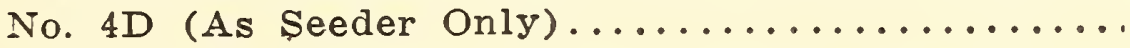

Plants in hills $4,6,8,12$ or 24 inches apart.

For use as a cultivator, the drill parts are removed and the tool frame substituted by changing but on $\theta$ bolt; it is then a perfect single wheel hoe, with a variety of tools, and a rapid change frame, with side extension for hooing both sides of a row at one passage.

No. 25 PLANET JR. COMBINED HILL AND DRILL SEEDER, DOUBLE WHEEL HOE, CULTIVATOR and PLOW

The simplicity of this tool, both as a seeder and as a wheel hoe, makes the combination thoroughly practical.

Two acres a day can easily be worked with this implement, and when it is done, it will be a better job than several men could have done in the same time with hand hoes.
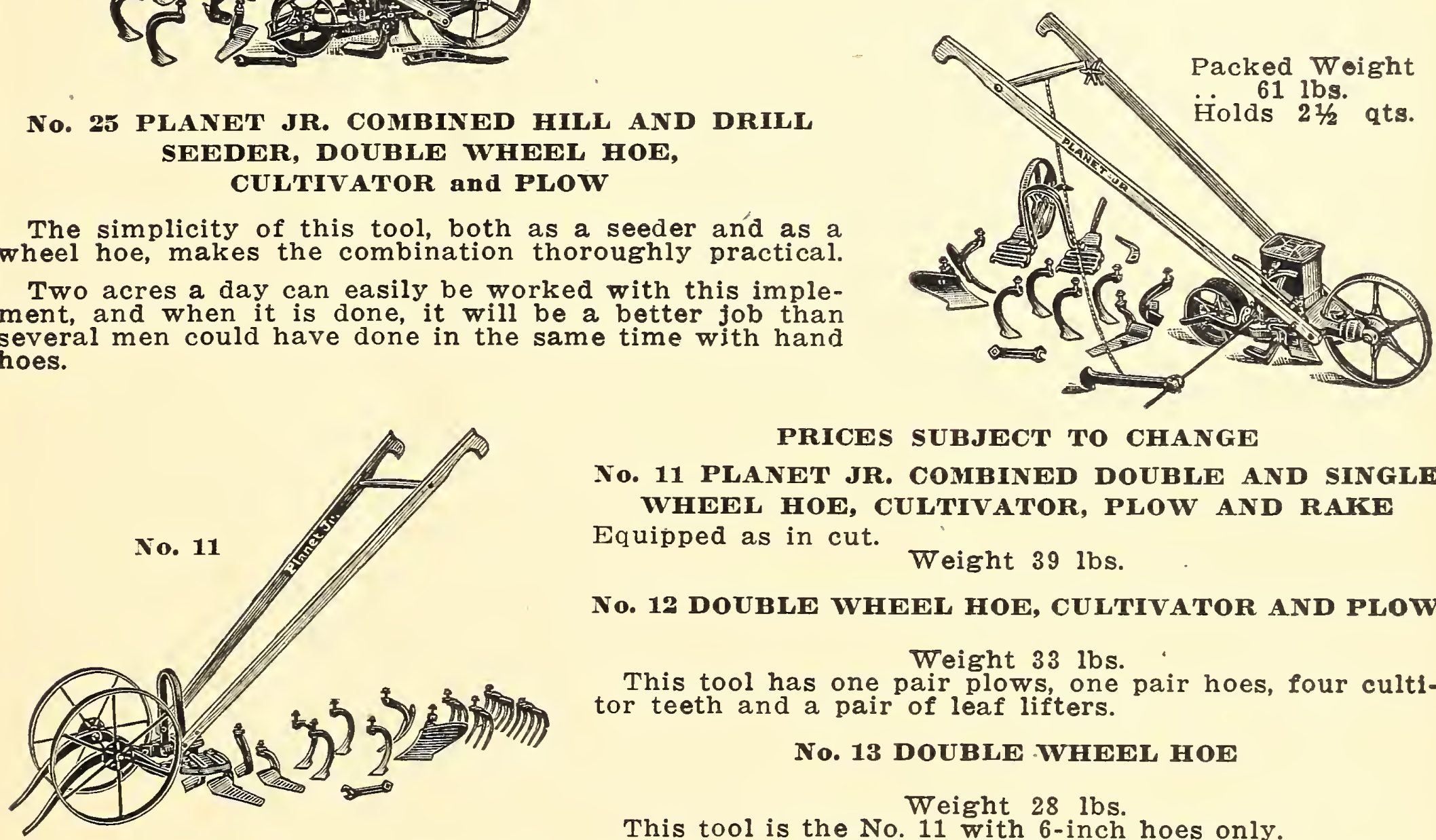

PRICES SUBJECT TO CHANGE

No. 11 PLANET JR. COMBINED DOUBLE AND SINGLE WHEEL HOE, CULTIVATOR, PLOW AND RAIKE Equipped as in cut.

\section{No. 12 DOUBLE WHEEL HOE, CULTIVATOR AND PLOW}

Weight 33 lbs.

This tool has one pair plows, one pair hoes, four cultitor teeth and a pair of leaf lifters.

\section{No. 13 DOUBLE .WHEEL HOE}

Weight $28 \mathrm{lbs}$

This tool is the No. 11 with 6 -inch hoes only.

No. 16 PLANET JR. SINGLE WHEEL HOE, Equipped as in cut. CULTIVATOR, RAKE AND PLOW

Weight $26 \mathrm{lbs}$.

No. 17 PLANE'T JR. SINGLE WHEEL HOE

Weight $24 \mathrm{lbs}$

The No. 17 has a pair of 6 -inch hoes, a plow and a set. of cultivator teeth, an outfit sufficient for most garden work.

\section{No. 18 SINGLE WHEEL HOE}

Weight 19 lbs.

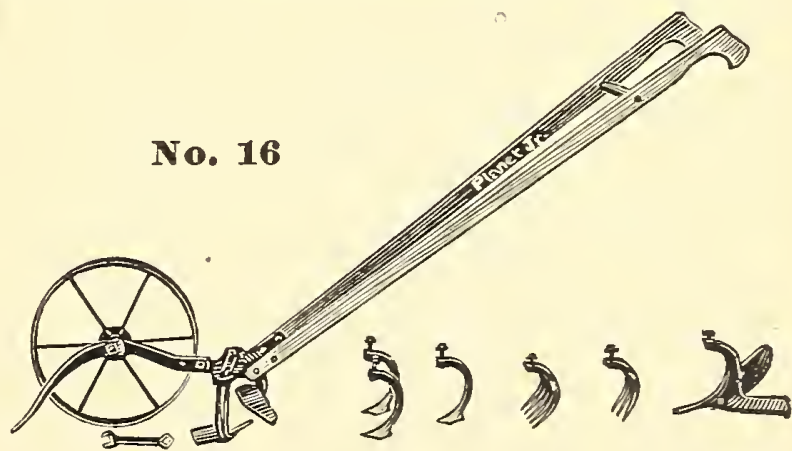

This has one pair of 6-inch hoes only.

NO. 8 PLANET JR. COMBINED HORSE HOE AND CULTIVATOR

No other cultivating machine is so widely known, for it is in use throughout the civilized world. So strongly built as to withstand incredible strain yet light and easy to handle.

PLANET JR. CATALOGUE ON APPLICATION

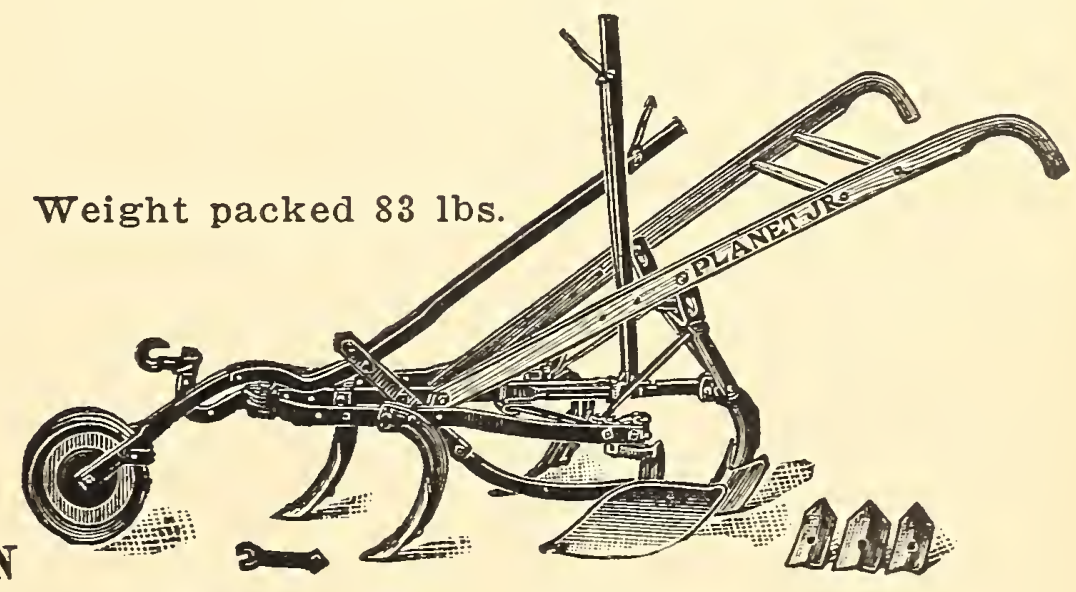




\section{PRICES SUBJECT TO CHANGR}

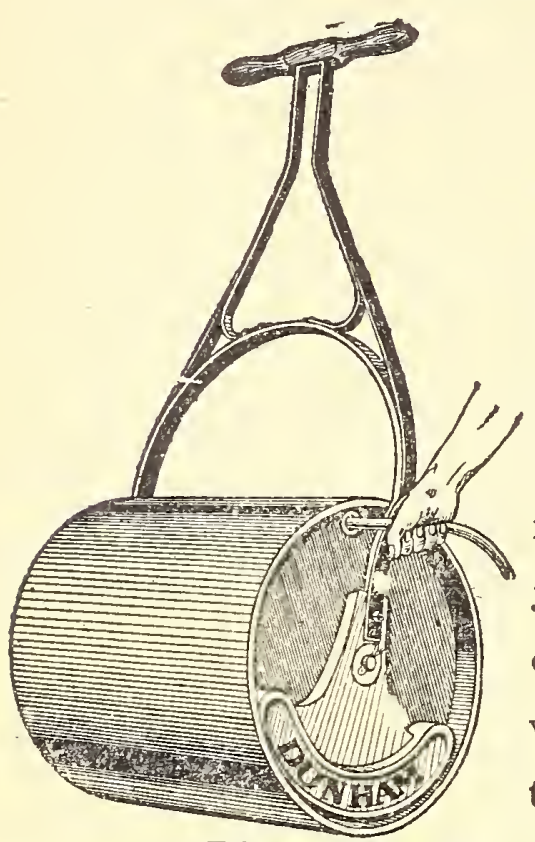

\section{WATER WEIGHT LAWN ROLLER}

These Rollers are smooth on face and rounded on outer edges to avoid cutting the lawn. Roller bearings make them 40 per cent easier to operate than the old-style roller. The fact that the weight is ad. justable for different lawn conditions is a great ad. vantage. Write for descrip. tive circular.

\section{Diam. Inchgth}

14

14
18
24
24
18
24
24

20
24
24
32
24
32
24

No.

WB3

WB5

WB7

WB9

WB11

WB13

WB15
Weight Filled with Empty Water

60
75
125
140
100
170
125

200
300
500
650
300
650
500

R E I C H A R D'S Magic: Wecder Hofs

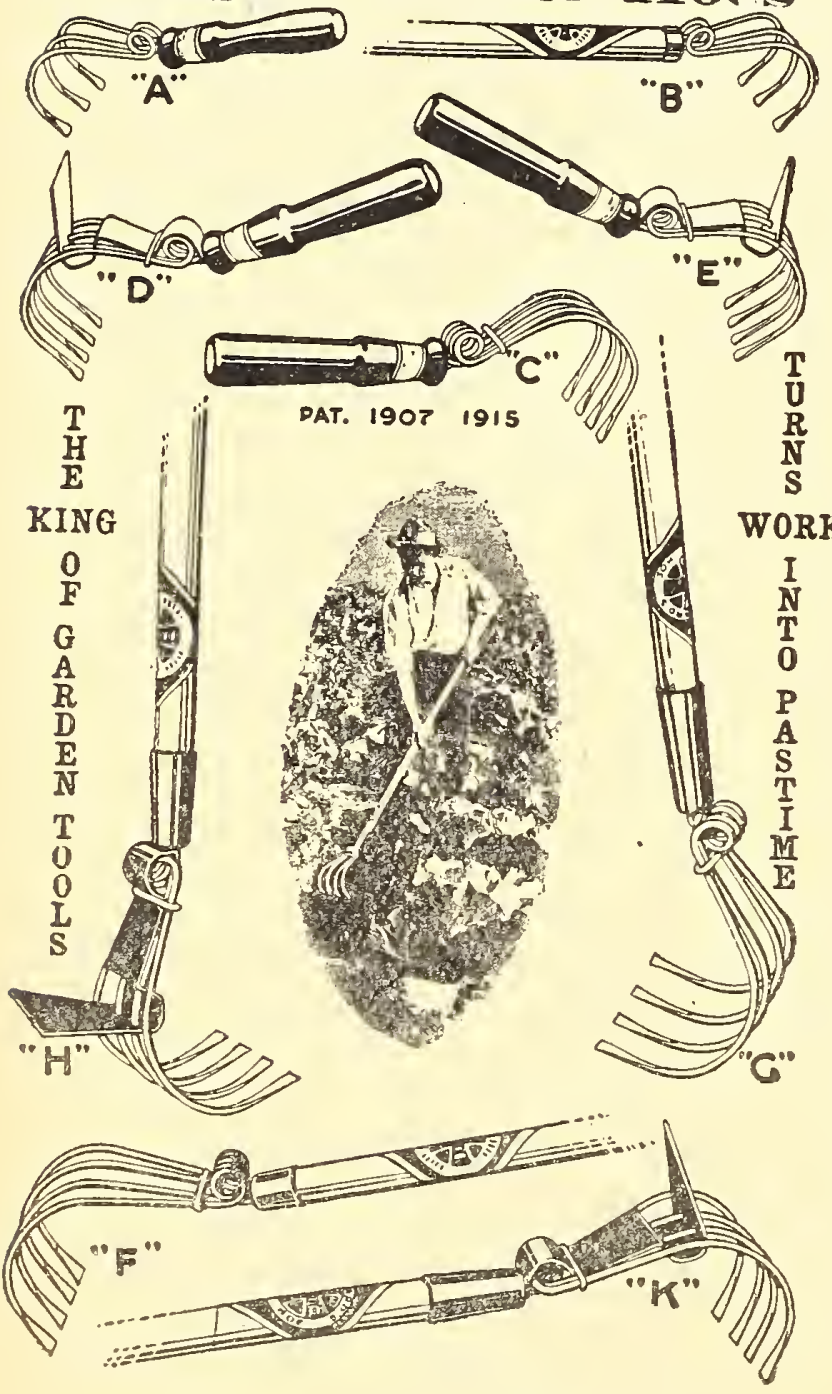

HANDY GARDEN TOOLS
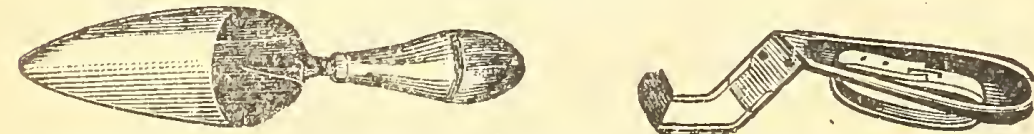

Solid Steel Garden Trowel.Jangr's Frand Weeder. COMBINATION SPRING-TOOTH

\section{GEM}

Dandelion

RAKE

Price

$\$ 11.00$

13.00

17.00

19.00

18.00

24.00

22.00 finger-hook.

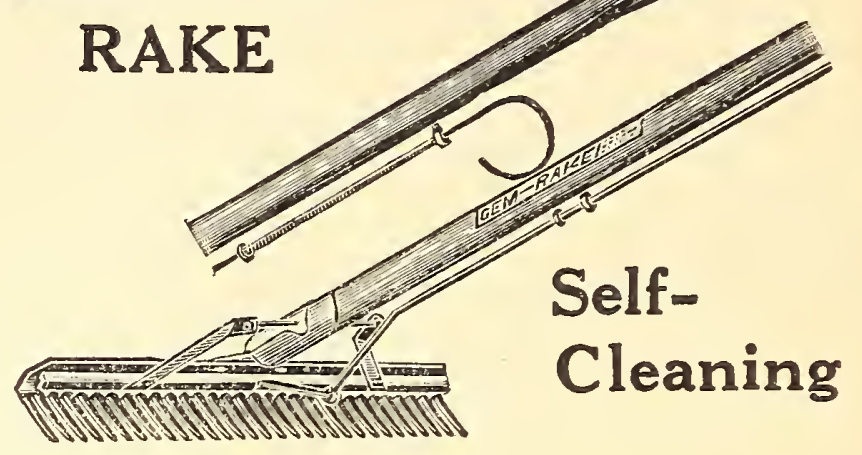

Will greatly improve your grass and the appearance of your lawn. Blade-like fine steel teeth slide over sod; rapidly clip off dandellons. Self-cleaning, stripper worked by light pull on

\section{Positively cannot tear or injure the sod.} Price:

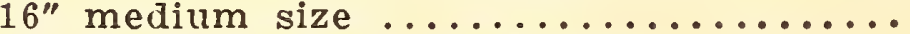

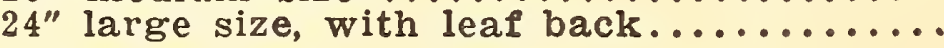

\section{ADJUSTO PLANT SUPPORT}

The "Adjusto" is a very simple, unbreakable, practical and cheap support which will last a lifetime. It is adjusted in a jiffy to any height, to conform to the plant's growth. It is indispensable for Toinatoes, Roses, Hydrangeas and Dahlias; in fact. everything on the lawn or in the garden that needs a support.

The stake is made of hard wood, having a protecting coat of green paint; the heavy spring wire is also painted green and so will not rust.

\section{MAGIC WEEDER HOES.} the shank, thus acting independently and making it work very easily, obviating all danger of clogging or breaking.

The tines are formed so as to enter the ground on the order of a cultivator or garden plow, lifting and pulverizing the snil, loosening and rendering friable, suberserving moisture, so essential to the rapid growth of young plants.

The Magic Weeder and Hoe is also provided with a steel blade or weed cutter and which is found to be very convenient in cutting roots or for making a small furrow. Also adapted for transplanting. An excellent tool for the sarden or greenhouse.

We furnish the Magic Weeder and Hoe as shown, and at the following prices:

No. A, without blade, short handle..15c No. B, without blade, 18-in. handle..20c No. C, without blade. short handle..25c No. D, with blade, short handle...40c No. E, with blade, short handle....40 c No. H, with blade, long handle.....1.00 No, K, with blade, long handle....1.00 No. F, no blade, long handle......50 No. G, extra heavy, no blade, iong handle ................75c
Each tine is provided with a coll near

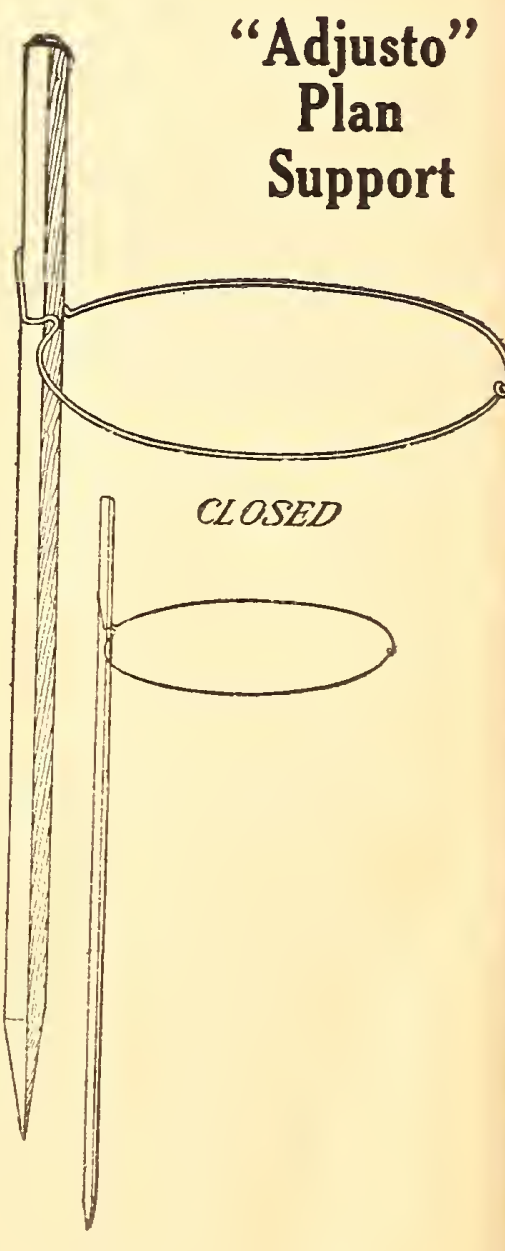

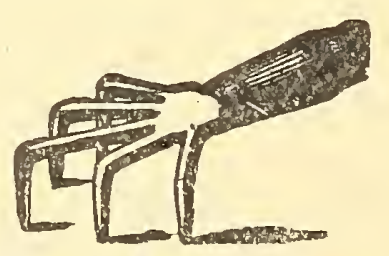

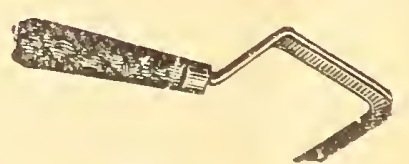

Fscelsior Eand Weeder. Tazeltine Weeder. 


\section{GENERAL DESCRIPTION}

\section{OF THE \\ No. 1-B and No. 2-B Clipper Cleaners}

These Cleaners are guaranteed to be first class in every respect. They are built by competent and skilled workmen and nicely finished in three coats of paint and varnish.

We can furnish the best outfit of screens ever sent out with a farm Mill. Our perforated zinc screens are graduated in 64ths of an inch in both round and oblong holes. Our woven wire screens are made of plated wire with the meshes uniform and true to count. The zinc screens will not rust and our plated wire screens will last for years if properly cared for.

We can make any separation on the Clipper, based on difference in sizes of seeds or grains, that can possibly be made with screens, and the Vertical Air Blast will make separations, based on difference, in weight, that can be made on no other mill and in no other manner.

Our screen outfit is very complete for the work required and contains screens for Wheat, Oats. Barley, Rye, Red and Alsike Clovers, Alfalfa, Sweet Clover. Timothy, Millet, Flax, Peas, Beans, Cow Peas, Soy Beans, grading Seed Corn, cleaning clover containing buckhorn, plantain or ripple, cleaning timothy seed containing pepper grass seed and sorrel; also Cane seed, Milo Maize, Kaffir Corn and separating corn from oats.

VERTICAI AIR BIAST. This is a feature that no other cleaner has and it makes posisible some very difficult separations that can be made in no other way. For instance, when cleaning seed wheat if the blast is properly regulated and the mill turned just fast enough, all the light shrunken kernels can be blown out or separated, leaving only the largest, heaviest. plumpest grain which is the choicest kind of seed. The same is true when cleaning seed oats-The Vertical Blast blows out all the light shrunken kernels and "pin oats" leaving. heavy weight, high grade seed. The same is true of Barley and Rye. If you use an air blast isufficiently strong on your seed grain you can raise the weight from three to five pounds per bushel. That is, the grain will weigh that much more per measured bushel, after being graded on the Clipper Cleaner. than it did before the light immature kernals were removed.

The No. 2-B differs from the No. 1-B only in size and capacity. Both machines are equipped with a set of 12 screens for general farm use. The No. 2-B is larger and of course does not turn as easy as the No. 1-B. For cleaning large quantities of grain or beans by hand we recommend the No. 1-B, but if you have a gas engine or other power, the No. 2-B is very satisfactory for cleaning grain or beans. Either Mill will do strictly first class work on Clovers. Timothy, Alfalfa and all kinds of seed, whether operated by hand or power.

We can furnish a 6" diameter driving pulley for either mill for 50 cents postpaid. When cleaning red or alsike clover or alfalfa containing dead or brown seed, the air blast can be regulated to blow out all seed that is not prime. When driven by power, the drive pulley should run 390 per minute.

CAPACITY NO. I-B

Wheat and other grain, 20 Bushels per hour. Clover and other Seed, 10 Bushels per hour. Screen length including spreading board 29". Screens 19 inches wide, $221 / 4$ inches long.

DIMENSIONS NO, 1-B

Length _-..-Width Height - -

Shipping weight, $185 \mathrm{lbs}$.

\section{SEEDERS}

\section{LITTLE GIANT SEEDER}

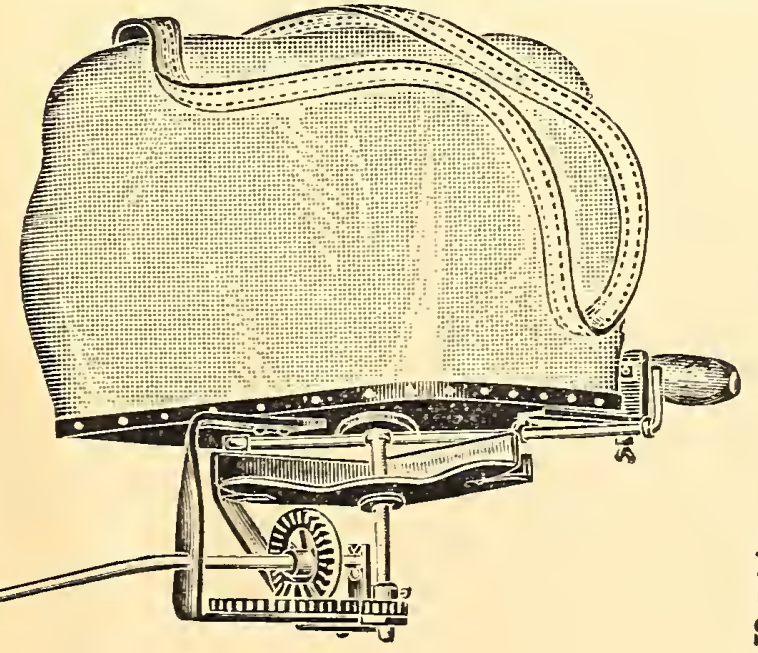

LITTLE GIANT SEEDER. The frame of this machine which carries all the bearing parts is made of the best metal. The seed is fed to the fan wheel through an adjustible slide in such a manner as to insure even distribution. The slide can be closed instantly. The Little Giant will sow any seed that is sown by hand and will do the work much better.

\section{CYCLONE SEEDER}

Simple in construction and easy of operation; has automatic regulator and cut-off, and performs its work perfectly. It is practical. Price $\$ 2.25$.

IDEAL SEEDER. Operates on same princlple Little Seeder as higher priced machines. 


\section{I'OULTRY FOODS}

PERFECTION CHICK STARTER. A clean mixture of small grain feeds, designed for the first feeding of young chicks. It is a balanced ration containing the easily digestable bone and muscle forming elements.

PERFECTION CHICK FOOD. A clean balanced ration of grain feeds, designed to carry the baby chick to an age when they can digest the coarser grains.

PERFECTION HEN FOOD. A balanced grain ration for the laying Hen. Contains corn, wheat, milo maise, kaffir, buckwheat, sunflower, millet and charcoal. Best grade of grains; all worthless matterial removed.

PERFECTION PIGEON RATION. A special prepared balanced feed, particularly adapted to the raising of young pigeons and squabs. Contains a liberal amount of Canada peas, wheat, milo maize, kaffir and buckwheat.

Pratt's "Buttermilk Baby Chick Food-21/2 and $5 \% / 4$ lbs. carton; 14 lb., $50 \mathrm{lb}$. and $100 \mathrm{lb}$. bags.

Conkey's Original Buttermilk Sterling Food-21/2, 5, 10, 25, 50, 100 1b. bags.

Ryde's "Start-Rit" Buttermilk Baby Chick Food4 1b. cartons; 10, 25, 50, 100 lb. bags.

DARLING'S MEAT CRISPS. Made from sweet meat trimmings carefully cooked, pressed and dried. Contains $75 \%$ protein. 3 1b. carton, 35c; 61/2 1b. carton, 70c.

SWIFT'S MEAT SCRAPS. A valuable food for laying hens and growing chicks. Rich in protein, meat scraps satisfies the craving for bugs and worms. Fine meal, medium, coarse.

BONE. Poultrymen find that for developing sturdy chickens nothing surpasses the liberal use of Bone Meal. Medium and coarse ground bone to be fed to laying hens.

Three sizes-Fine meal, medium, coarse. GENUINE CRUSHED OYSTER SHELL. As material for forming egg shells this is a most essential feed for the laying hen. We invite your inspection of "Pilot" and "Antelope" Brands.

GRIT. Every poultry man realizes the value of Grit for the paying hell. It creates perfect digestion because it keeps things in the crop on the move, $o$ wing to the fact that the corners of the pieces always remains sharp.

CHARCOAL. Successful poultrymen feed charcoal to the growing chick and laying hen. Charcoal promotes health.

Three sizes-Fine, medium, coars. In cartons, $20 \mathrm{c}$ each, and $50 \mathrm{lb}$. bags.
OIL MEAL. A little pure linseed meal fed occasionally to laying hens assist nature to keep the system in order. It is especially recommended if rich, glossy plumage is desired.

ALFALFA MEAL. The universal substitute for green grass feed. Contains the fine ground leaves of specially cured alfalfa. Used generally for prepared mash feeds and for floor covers in the rearing of baby chicks. Fine, medium and coarse.

\section{StimUplanT Makes a Wonder Garden}

\section{RYDE'S CALF MEAL.}

\section{(Richest Substitute for Milk)}

A meal that makes calves strong and healthy. Contains everything necessary for their rapid and symmetrical growth. Safe for the baby calf. Made with the care of baby food. Cooked by special process to render it easy to digest. No filling or indigestable matter to cause scouring. The milk for one calf will pay for the raising of three on Ryde's Calf Meal. Fully guaranteed.

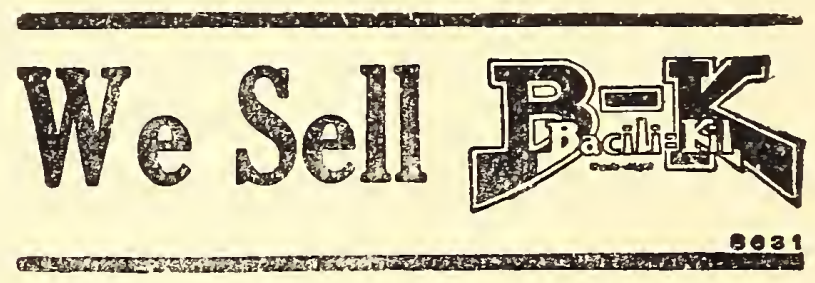

\section{BIRD SEED AND SUPPLIES}

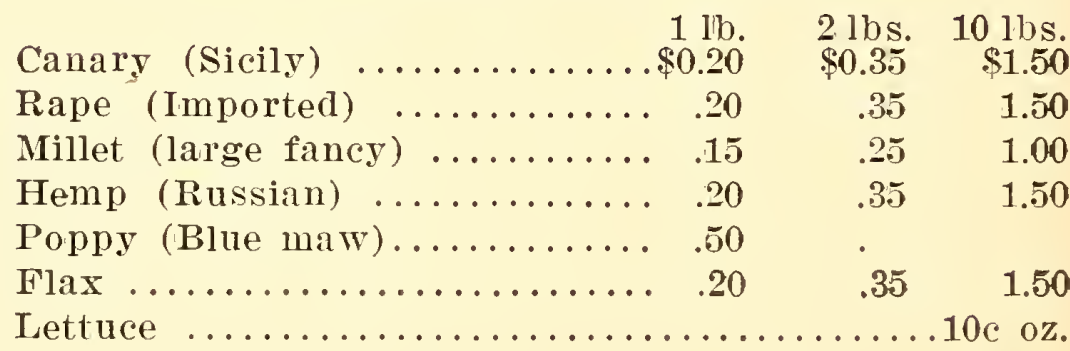

Steel cut oats and wild rice

Sunflower (Mammoth Russian)

Nebseeco mixed bird seed.

All clean, plump seeds mixed proportionatels to promote health. A mixture for years called for by experienced bird raisers and fanciers.

$1 \mathrm{lb}$., 20c; 2 lbs. for $35 \mathrm{c} ; 10$ lbs. for $\$ 1.50$. Cuttle Bone-Large, 5c, and small, 2 for $5 \mathrm{c}$.

Bird Manna-15c each; 2 for $25 \mathrm{c}$.

Bird Bitters-25c.

Bird Gravel (magnesia bird grit with charcoal)-15c; 2 for $25 \mathrm{c}$

Bird Nesting ............................ . .

Bird Nests .............................

Lice Powder ........................ 0 c

Glass and opal cups......................20c 


\section{BUCKEYE AND SURE HATCH INCUBATORS AND BROODERS PRICE AND CATALOGUE ON APPLICATION}

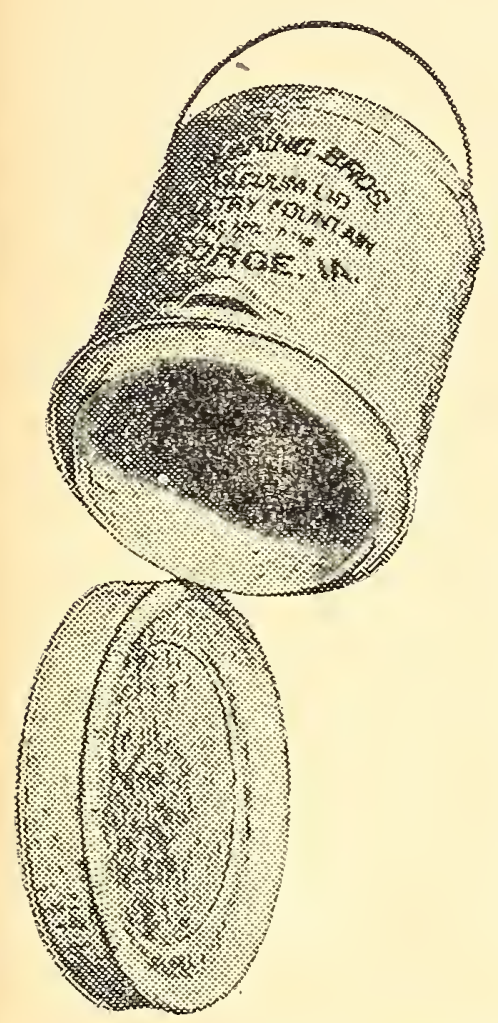

\section{SILBRING'S THERMO POULTRY FOUNTAIN}

A Thermo Fountain that can be cleaned, repaired and filled the same as a common watering pail. Keeps water warm in winter and cool in summer. Drinking water is available all around the base of this fountain. (See cut.) 5 gallons only $\$ 5.50$.

\section{THE O. K. SANITARY THERMO FOUNTAIN}

A Thermo Fountain that is absolutely sanitary. The inside tank can be removed, thus making it possible to wash clean.

No. 300-21/2 gal., $\$ 4.75 ;$ No. 500-5 gal., $\$ 5.50$ No. 50-Same as above without removable top, $\$ 4.50$.

\section{THE BABY THERMO FOUNTAIN}

Holds one-half gallon of water. Insulated the same as larger thermo fountains and is reliable in the average poultry house. Keeps water warm in the winter and cool in the summer. Each, $\$ 1.50$.

\section{SANITARY FEEDING TROUGHS FOR GROWN FOWLS}

Suitable for dry feed, wet mash or water. The top slides off, so the pan can be easily cleaned and filled. Best quality galvanized iron.

Nevada-30 inch length, 6 in. wide..........\$0.75

Carter-18 inch length, 6 in. wide...............

Carter-24 inch length, 6 in. wide................. 1.50

Kentuco-24 inch length, 5 in. wide........... 1.00

\section{MOE'S DOUBLE FEEDING TROUGH}

Made of best quality galvanized iron, sliding top. No sharp edges to injure chicks.

No. $58-12$ in., each....................

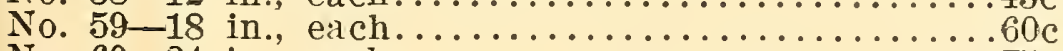

No. $60-24$ in., each.......................

MOE'S SINGLE FEEDING TROUGHS

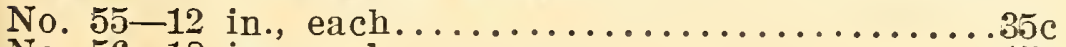

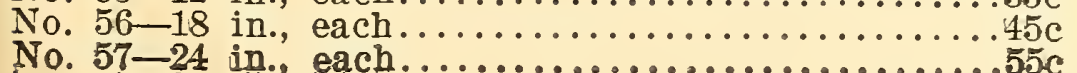

\section{MOE'S LARGE CAPACITY FEEDER}

A wonderful feeder for young growing stock. Feeds 32 chicks at one time. Made of heary galvanized iron, length 21 in., width $81 / 2$ in., height 7 in., capacity 10 qts., wt. $24 \mathrm{lbs}$.

No. 140 - Chick Feeder .....\$1.25

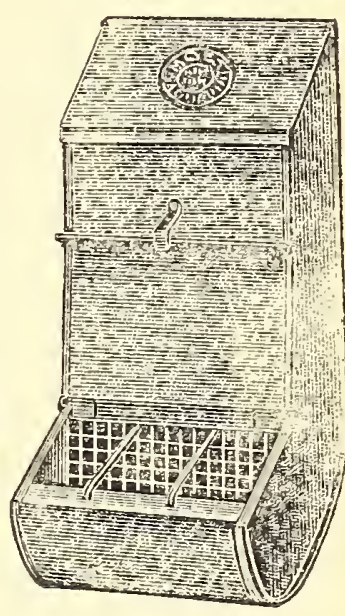

\section{MOE'S MAGAZINE CHICK FEEDER AND WATERER}

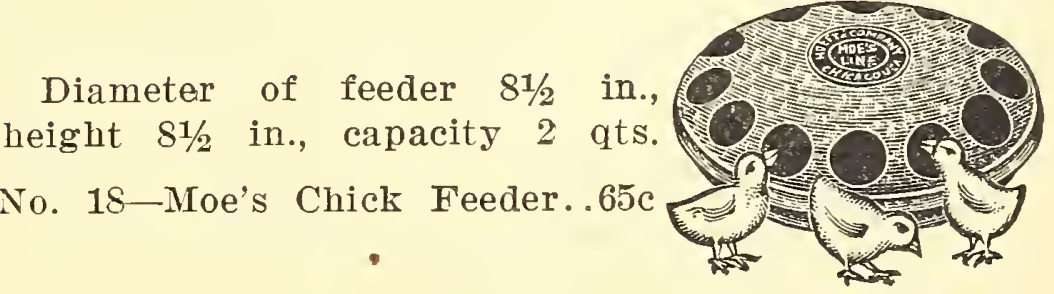

\section{THE FAMOUS STAR JAR FOUNTAIN}

Made of a single piece of heary non-rusting metal. Made in one size only, which will fit any Mason jar. (We do not furnish Mason jars.)

No. 32-Star Fountains-10c each. Doz.-\$1.20

\section{MOE'S ROUND BABY CHICK FEEDER}

Made of the best quality galvanized iron. Top fits singly, yet can be taken apart for cleaning and filling.

No. 12-Diameter $81 / 4$ in., each............25c

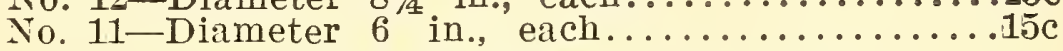

\section{MOE'S PIGEON FEEDERS}

Pigeons are fastidious feeders with a tendency to scatter and waste feed. Made of galvanized iron. A practical, economical feeder that will soon save its cost.

No. 105-Capacity 3 qts.................\$1.00

\section{MOE'S PIGEON NESTS}

Made of galvanized iron. Diameter $\delta$ in. with small hole punched in the center so it can be tacked on a board. Light in weight, yet substantial and easily cleaned.

No. 107-Pigeon Nests, each, 15c; dozen, $\$ 1.80$.

\section{MOE'S POULTRY VEGETABLE RACK}

Made of best quality galvanized iron with galvanized wire rack. A practical device for holding roots, beets, cabbage, sprouted oats, clover, etc. Prevents scattering and wasting of food. The round bottom trough catches the small tender leaves, thus feed

saved soon pays for the rack.
No. 44 Vegetable Rack, each 75 c; dozen, $\$ 9.00$.

\section{MOE'S TRAP NEST FRONT}

Made of the best quality galvanized iron. Can be easily fitted to arrange on any wood box. Effectively traps the hen, yet allows ample ventilation. 11 in. wide by 12 in. high.

No. 63-Trap Nest Front, each, 50c; dozen, $\$ 6.00$

\section{POULTRY PUNCHES}

No. 38-Moe's Punch, each...............25c No. 39-Moe's Ideal Punch, scissors type, each....30c

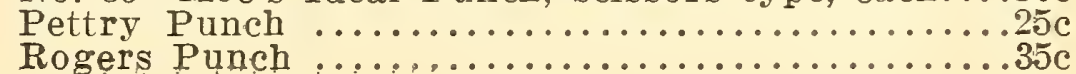




\section{POULTRY REMEDIES}

\section{LEE'S POULTRY REMEDIES GERMAZONE}

(Liquid)-4 oz. bottle, $40 \mathrm{c} ; 12$ oz., 75c; 32 oz., $\$ 1.50$. (Tablets) -20 tablets, 25c; 75, 65c; 200, \$1.25.

Egg-o-latum-2 oz. jar, 50c.

Egg-o-hatch-2 oz. jar, $50 \mathrm{c}$.

Lee's Louse Powder-1 1b. pkg. 25c; 21/2 lb. pkg., 50c. Lee's Lice Killer-Qt., 60c; 1/2 gal., 90c; gal. \$1.50.

Lee's Dry Rub-3 1b. pkg., 50c.

Lee's Fly Curo-Qt., 60c; 1/2 gal. 90c; gal., $\$ 1.50$.

Head Lice Ointment-2 oz. cans, $15 \mathrm{c}$.

Lee's Egg Maker-2 1b. pkg., 40c; 5 Ib. pkg., 90c;

12 1b. pail, $\$ 2.00 ; 25$ lb. pail, $\$ 3.75$.

Lee's Special Hand Sprayer-Qt. size, 65c.

Lee's Tobacco Worm Powder, 4 oz., 25 c.

Lee's Sodium Fluoride Lice Powder-6 oz., 25c; 11/2 $1 \mathrm{~b} ., 75 \mathrm{c}$.

\section{CONKEY'S REMEDIES}

Conkey's Roup Remedy, 30c, 60c, \$1.20.

Conkey's Roup Pills-30c, 60c, \$1.20.

Conkey's Cholera Remedy-25c, 50c.

Conkey's Gape Remedy-25c, 50c.

Conkey's White Diarrhea Remedy-25c, 50c.

Conkey's Sore Head Remedy-25c, 50c.

Conkey's Canker and Bronchitis Remedy-50c.

Conkey's Limberneck Remedy-50c.

Conkey's Poultry Laxative-25c, 50c.

Conkey's Blackhead Remedy-50c.

Conkey's Worm Remedy-25c, 50c.

Conkey's Scaly Leg Remedy-25c.

Conkey's Sulphur Candles-10c.

Conkey's Lice Powder-15 oz., 25̌c; 48 oz., $50 \mathrm{c}$

Conkey's Head Lice Ointment-1 oz., 10c; 3 oz., $25 \mathrm{c}$.

Conkey's Lice Fix-25c.

Conkey's Poultry Tonic 11/2 lbs., 25c; 31/4 lbs., 50c; 7 lb., $\$ 1.00 ; 12$ lb. pail, $\$ 1.60$.

Conkey's Noxicide and Disinfectant-25 1b. pail, $\$ 3.00$; pint, 50c; qt., 80c; $1 / 2$ gal, $\$ 1.30 ;$ gal., $\$ 2.00$.

Conkey's Nox-6 cubes, 25c; 15 cubes, 60c.

Conkey's Fly Knocker-qt., 60c; 1/2 gal., 90c; gal, $\$ 1.50$.

\section{NEST EGGS}

Lice repulsing white sanitary nest eggs of superior quality and appearance. Keep the nest free from vermin. Soon pay for themselves. Per doz, 60c.

China Nest Eggs. White porcelain, natural in appearance, uniform in size. Will not break easily. Dozen, 40c. 3 for $10 c$.

\section{WIRE HENS NESTS}

Made of copper steel wire with flat steel ribs and heavy top wire, all copper finish. Intended to fasten to wall. $12 \mathrm{in}$. diameter. Each, 23ōe Dozen, $\$ 2.80$.

\section{MISCELLANEOUS POULTRY SUPPLIES}

Incubator Thermometer, Universal, with stand-each, $\$ 1.00$.

Incubator Thermometer, with stand-each, $75 \mathrm{c}$.

Brooder Thermometer. Thermometer on round holder to be inserted in holes in top of brooder. Length, 10 inches. Each, $\$ 1.25$.

Hygrometer-Each, $\$ 1.50$.

Hinged Lamp Burners for Incubators, Brooders, Drinking Fountains, etc. Size No. 1-50c each; Size No. 2-75c each; Double wick burner- $\$ 1.00$ each.

Lamp Wicks-Cotton, 2 for 5c; Red felt, 5c each.

We carry Lamp bowls, chimneys, smoke pipes and elbows for brooder stoves.

\section{PRATT'S REMEDIES}

Pratt's Powdered Lice Killer-1 lb. pkg., 25̌c; 31 b. pkg., 50c.

Pratt's Roup Tablets or Powder-25c, 50c.

Pratt's Special Compound-25c, $50 \mathrm{c}$.

Pratt's Condition Tablets-25c, 50c.

Pratt's Gape Compound-25c, 50c.

Pratt's Scaly Leg Ointment-25c.

Pratt's Red Mite Special-Qt., 65c; 1/2 gal., $\$ 1.00$ gal., $\$ 1.80$.

Pratt's Disinfectant and Lice Killer-Pt., 30; qt. 5̆c ; $1 / 2$ gal., $\$ 1.00 ;$ gal., $\$ 1.75$.

Pratt's White Diarrhea Tablets-25c, 50c.

Pratt's Sore Head and Chicken Pox-30c, 60c.

Pratt's Bronchitis Tablets-25c, 50c.

Pratt's Head Lice Ointment-25c.

Pratt's Lice Salve-15c, 25c.

Pratt's Poultry Regulator-24 oz., 25c; 4 lb., 50c; 9 lb., $\$ 1.10 ; 12$ lb., $\$ 1.40 ; 12$ 1b. pails, $\$ 1.60 ; 25$ $1 b ., \$ 3.00$.

\section{STANDARD REMEDIES}

Standard Protexal (Dry Dip)-1 Ib., 40c; 3 Ibs., 75c. Standard Poultry Tonic-2 lbs., 35c; 5 lbs., 75c; 10 lbs., $\$ 1.25 ; 25$ lib. pails, $\$ 3.00$.

Standard Liquid Lice Killer-Qt., 60c; 1/2 gal, 90c; gal, $\$ 1.50$.

Standard Insect Destroyer-1. 1b., 25̌c.

Standard Roup Remedy-4 oz. box, 50c.

Standard Chicuro, White Diarrhea Tablets-50c.

Chlorine-16 oz. bottle, 65̌c; tablets, box, 65c.

B-K-liquid-4 oz. bottles, 35c; 8 oz., 60c; 32 oz., \$1.25. Oculum-Bottle, 60c.

Smoke-Em-Can, $\$ 2.00$

Succulenta Tablets-100 tablets, 50c; 250 tablets, $\$ 1.00$ Carbola (whitewash disinfectant paint) $-51 \mathrm{bs} ., 75 \mathrm{c}$ $10 \mathrm{lbs} ., \$ 1.25 ; 501 \mathrm{bs} ., \$ 5.00$.

Don Sung (Chinese Egg Laying Tablets)-50c, $\$ 1.00$ 


\section{PRICES SUBJECT TO MARRET CHANGES}

\section{POULTRY LEG BANDS}

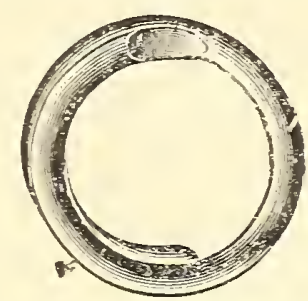

Key Ring colored celluloid leg bands. Fast colors. Keep their shape, will not fade and are weatherproof.

Made in six sizes for Asiatics, American, Mediteranean, bantam, pigeon and baby chick.

Iade in ten colors, white, black, red, garnet, pink, green, dark blue, light blue, purple, yellow.

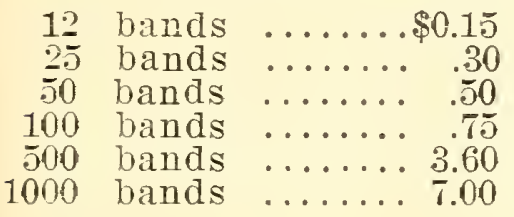

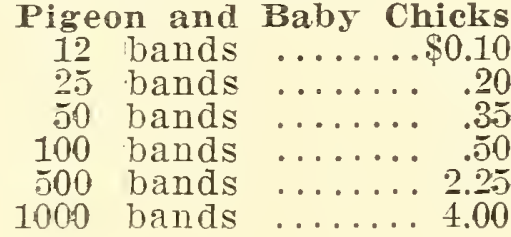

\section{ALUMINUM LEG BANDS}

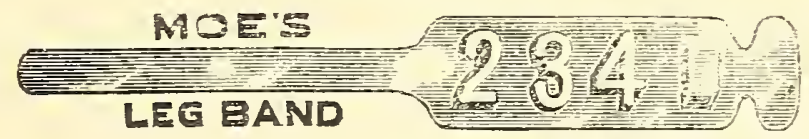

Made of sheet aluminum, with large raised numbers, easy to read. Adjustable to any size fowl.

\begin{tabular}{|c|c|c|c|}
\hline n & . .\$0.15 & 100 & bands \\
\hline bands & $\cdots \cdots$ & 1000 & bands \\
\hline
\end{tabular}

\section{THE VICTOR POULTRY BAND}

The Victor bands are made made in colors and hare extra large printed numbers, readable 10 to 15 feet away. Just the band for show birds.

Supplied in the following colors: Red, white, blue, sreen and sellow.

Made of extra heavy aluminum, smooth finish and locks with double clinch.

12 for $50 \mathrm{c} ; 25$ for $\$ 1.00$; 50 for $\$ 1.85100$ for $\$ 3.50$.

\section{THE RELIABLE POULTRY BAND}

The Reliable leg bands are smaller in size and are manufactured from material that is lighter in weight than what is used in the Victor bands. Made in colors: Red, white, blue, green and yellow. Supplied 50 for $\$ 1.00 ; 100$ for $\$ 1.90$.

\section{LEG BANDS}

Colored Leader Adjustable leg band. A general purpose band. Light in weight. Continuous line of color all around the band. Good for trap nesting. Furnished in red, blue, green, white, sellow and pink. 12 for 25c; 25 for $50 \mathrm{c} ; 100$ for $\$ 1.25$.

Double end clinch bands, wing bands for baby chick. 12 for $15 \mathrm{c} ; 25$ for $25 \mathrm{c} ; 50$ for $35 \mathrm{c} ; 100$ for $60 \mathrm{c}$.

Aluminum and celluloid pigeon bands. These bands are of open style, large numbers, come in pairs with same number on each band. 12 for $40 \mathrm{c}$ : 25 for $75 \mathrm{c}$; 50 for $\$ 1.40 ; 100$ for $\$ 2.50$.

\section{CAPONIZING SETS}

Poultrymen can double their profits by caponizing. The operation is very simple. Philadelphia caponjzing set.-Ask for prices.

\begin{tabular}{c}
\hline $\begin{array}{c}\text { StimUplan T } \\
\text { Makes a } \\
\text { Wonder Garden }\end{array}$ \\
\hline
\end{tabular}

\section{OAT SPROUTERS}

H. A. Sterens practical quick groming oat sprouter. No lamp.

8 pan-11x15 in.-wt. 18 lbs.

8 pan--11x33 in. - wt. 35 lbs.

5 pan-11xis in. - -12 t. $13 \mathrm{lbs}$

5 pan-11x33 in. - -2 t. $25 \mathrm{lbs}$

Moe's Oat Sprouter. The Sectional steel frame can be quickly taken apart and stored in a small place. Fire of the pans hare a perforated bottom to secure drainage, and the bottom pan is solid to hold drippings. Pans are interchangeable.

Height 3 ft.s pan 16 in by 18 in., $\pi t .30 \mathrm{lbs}$

No. 110 Oat Sprouter, each.. $\$ 6.00$

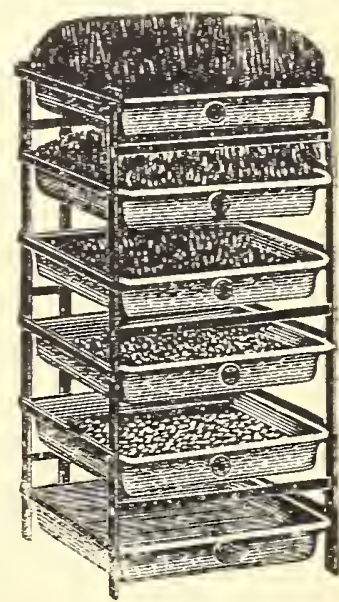

\section{GRIT AND SHELL BOXES}

Ioe's No. 90-3 compartment, round bottom.....\$0.90 Ioe's No. 9-4 compartment, round bottom..... 1.25 O. K. -2 compartment, square bottom........ 1.00 Kentuco--1 compartment, square bottom, for baby chicks 45

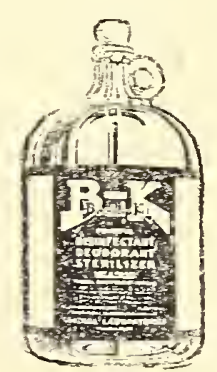

\section{DRY MASH HOPPERS}

A Dry Mash Fopper made of heary galvanized iron. Especialls made to prevent clogging and waste.

Height Width Capacity Wt. Each No. 35-19 in. 81/2 in. 10 qts. $t$ lbs. $\$ 1.50$ No. 36-19 in. 12 in. 14 qts. 5 lbs. 2.00 No. $13-19$ in. 18 in. 22 qts. $6 \mathrm{lbs} . \quad 2.40$ No. 37-19 in. 24 in. 32 qts. $10 \mathrm{lbs} . \quad 2.80$ No. 3-181/2 in. 21 in. length. 35 in., capacity $100 \mathrm{lbs}$. height of stand $1 \tilde{5}^{1 / 2}$ in. Total height $341 / 2$ in.; wt. 50 lbs. Hopper feeds from two sides. 


\section{LARGER CROPS in FIELD and GARDEN}

Registered in the

United States Dec. 6tho 1898.

25 YEARS AGO. if you use

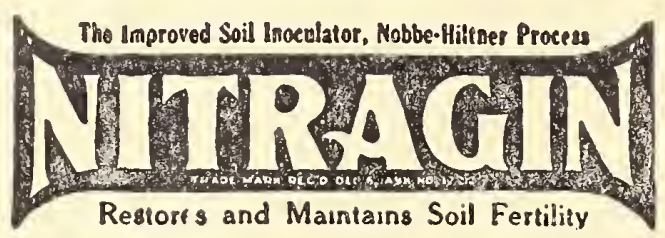

Awarded Gold Medal

Worlds Fair - St. Louis

1904.

19 YEARS AGO.

Alfalfa, clovers, soybeans, vetches, peas, beans, cowpeas, peanuts and other legumes should always be inoculated witr Nitrag.n. The lack of necessary bacteria in the soil is often the cause of a poor legume crop-a weak start-or a total failure.

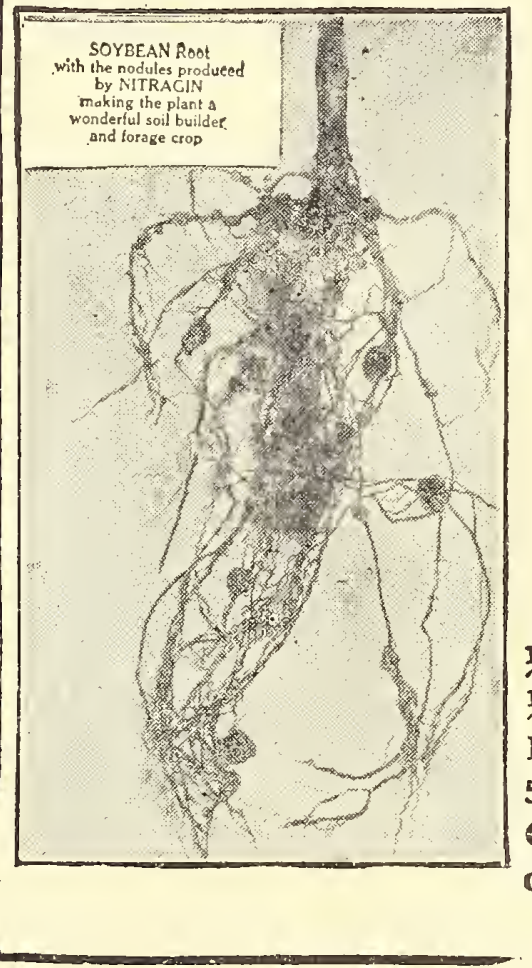

\section{A Great Price Reduction NITRAGiN Costs Less}

Nitragin now comes in Bushel sizes instead of acre sizes. This means that it costs you less per acre than inferior imitations. If you sow 12 pounds of seed to the acre it will only cost you 20 cents for your Nitragin. It means that

\section{Your Dollar Goes Further With NITRAGIN}

Nitragin is an old, reliable inoculator. At the low price of 20 to' 33 cents per acre you cannot afford to sow legumes without it. Nitragin is put up in the modern ventilated packrge; in a rich, soil-like packing medium. The contents are always fresh, living bacteria to feed your plants. Easy to use.

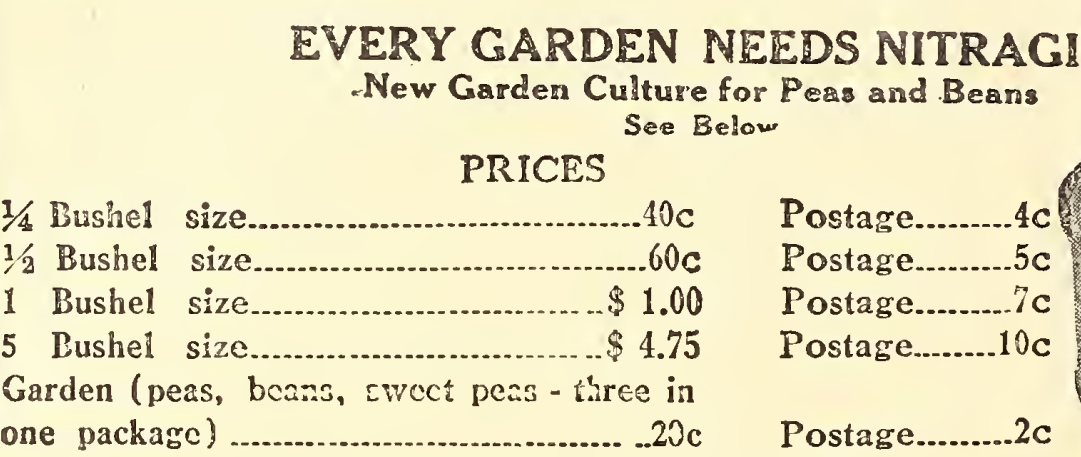

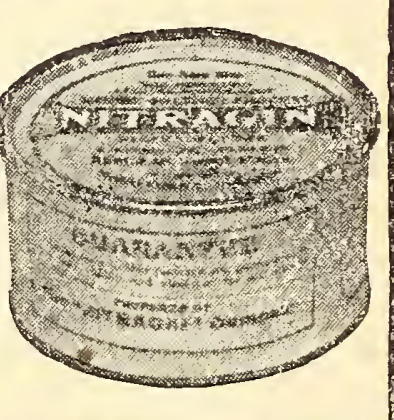

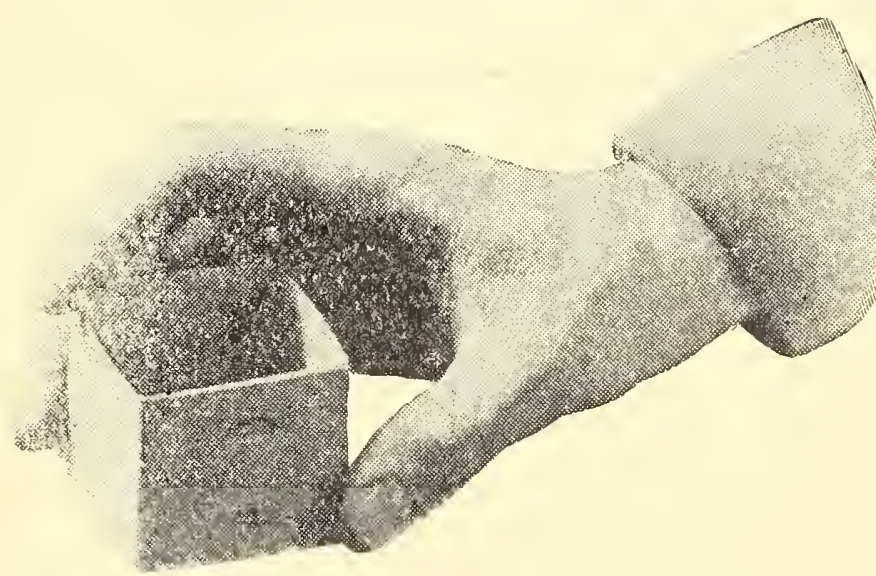

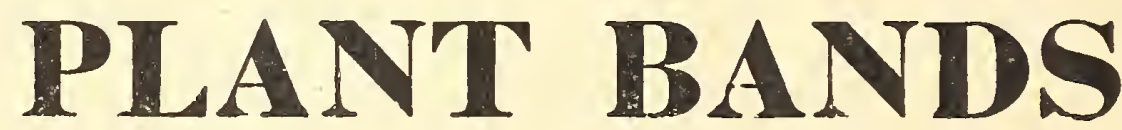

This device makes it possible to raise plants such as tomatoes, cabbage, peppers, etc., as pot grown plants and saves from 8 to 10 days on maturing said vegetables, as it will keep roots from injury at time of transplanting. Remember early vegetables are the ones which bring high prices and are more desired by amateurs as well as professionals.

Plant bands $2^{\prime \prime} \times 2^{\prime \prime}$ are the most convenient size used for flower and vegetable plants usually used by the amateur as well as by the professional gardners. They are put up in cartons of 250 each.

$$
\begin{aligned}
& 1 \text { Carton (250) ....\$1.25 } \\
& 4 \text { " (1000)....4.50 }
\end{aligned}
$$

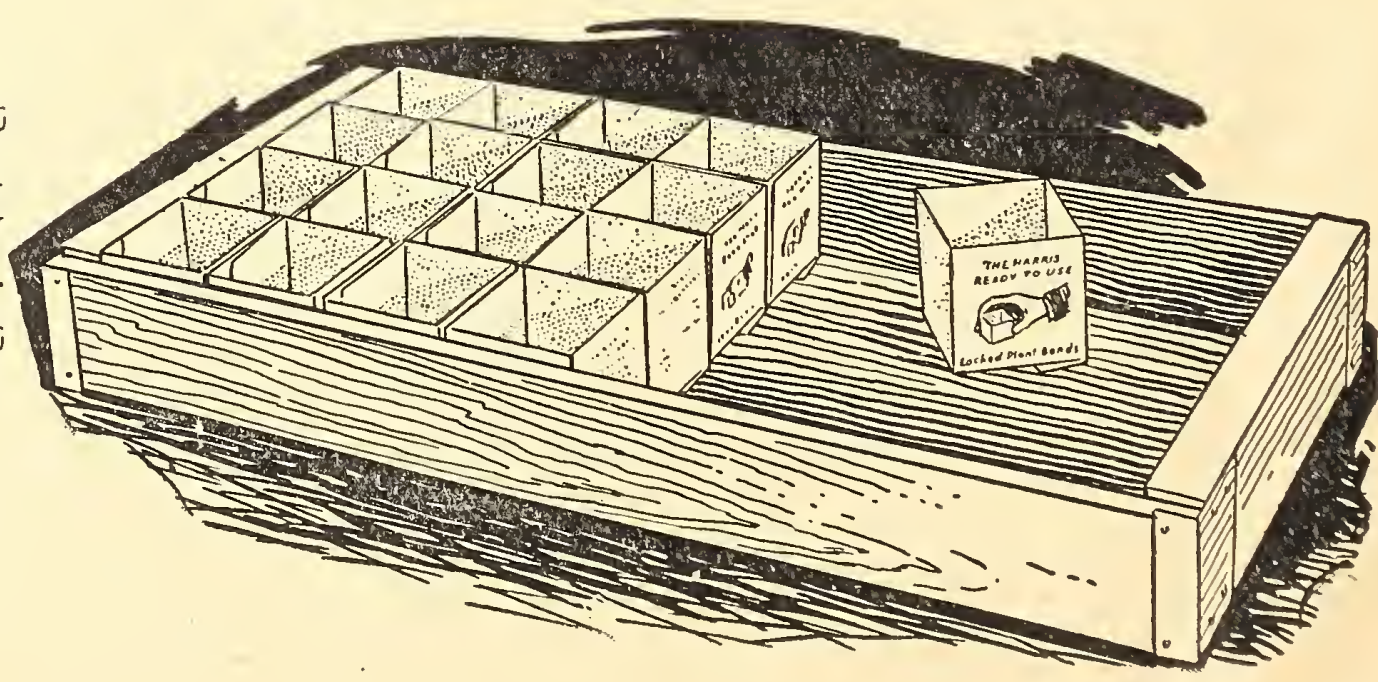




\section{N D E X}

Achillea

Alfalfa -

Alsike --

Alyssum _-_-_-_-_- 26

Amaranthus s

Antirrhinum -

Aquilegia - -

Artichoke

Aster

Balsams _-_.-.--

Balsam, Apple and Pear

Barley -..-

Beans -

Bird Seeds

Blatchford's Foods

Bone Cutters _.

Borecole -

Broadcast Seeders _-_-_-_59

Bromus Inermus

Broom Corn

Brussels Sprouts

Buckwheat _.......... 49

Bulbs, Flowering _- $37-38-39$

Cabbage -

Caladium

Calf Meal

Calliopsis

Canary Bird Vine-.--

Cane, Sugar or Sorghum -52

Candytuft _.

Canna

Carrot

Castor Beans

Cauliflower

Celery - Celosia

Centaurea

Chervil

Chicory

Chives

Chrvisanthemum

Cinnamon Vine

Clovers -

Cobaea -.

Cockscomb -

Columbine _.

Coreopsis Broom

Corn, Field -

Corn. Fop

Corn, Sweet _-

Corn, Salad -

Cosmos

Cow Peas

Cress

Cucumber

Cultivators

Cypress Vine

Dahlia

Daisy-Shasta

Delphinium

Dianthus -

Dielytra -

Digitalis

Drills _..-

Egg Plant

Elephant's Ear

Endive

Emmer

Eschscholtzia

Esparsette

Everlasting Flowers -
Fertilizer

Feterita

$-39$

Flax --

Forget-Me-Not

Four O'Clock -._.-_-_._- 28

Foxglove

Gaillardia

Garden Tools

Geranium -_._-

Gladiolus

Gourds. Ornamental _.

Grass Lawn ---------

Grass Seeds --_----45-46-47

Gypsophila

Heliotrope

Herbs -

Hibiscus Hollyhocks

Horseradish

Humulus _...-...-_.

Hyacinth Bean _..._._._- 29

Hubam Clover

Incubators _.

Insecticides

Inoculation

Iris.

Japanese Hop _........ 28

Job's Tears _.._._._._. 28

Kaffir Corn -

Kale ------------------ 11

Kochiä-ō̄i

Kohl Rabi Vine

Larkspur

Lawn Rollers

Leek Rollers -

Lettuce

Lobelia

Lillies

Leg Bands

Madeira Vine _._._._. 39

Marigold - -

Mangel Wurzel

Matrimnny Vine

Melons _-_-_-_-_-_-_-13-14

Mills for Cleaning Grain_-59

Millet

Milo Maize

Moonflower Morning Glory

Mushroom Spawn _._._._11

Mustard

Nasturtium

Nicotiana

Nebseeco Calf Meal-_.

Nitragin

Oats

Okra or Gumbo

Onions

Onion Sets

Oyster Plant
Pansy -

Parsley

Parsnip -...-

Peanuts

Peas, Cow

Peas, Field

Peas, Garden

Pepper -

Petunia - -

Phlox -

Planet, Jr. Tools--

Poppy

Potatoes - Sweet

Portulaca

Poultry Remeđies

Poultry Supplies

Primrose _...

Pyrethrum

Rutabaga - _.......-.

Radish -

Rape

Rudbeckia

Rye - -

Salsify

-

Schrock Kaffir-Sorghum - - 32

Seed Cleaners

Seed Sowers _.

Shallu -...- 59

Sorghum

Speltz -.-_-_-

Spinach -

Sprayers _-_-

Squash -.--

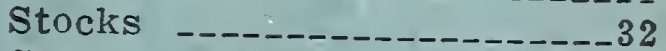

Sudan Grass

Sugar Beets

Sugar Cane _..._.

Summer Cypress _-_._-_. 29

Sunflower

Sweet Clover

Sweet Corn _-_-

Sweet Peas _-_._-_-_-_- 33

Sweet William

Sweet Rocket

Tobacco

(1)

Tuberoses

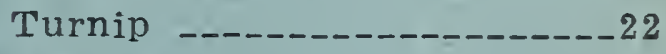

Verbena -

Vetch _..._-____._. _- 50

Violet _...

Theat

Wild Flower, Garden...-.32

Wild Cucumber _..... _..--32

Weeders

Yucca

Zinnia _- 


\section{WE ARE HEADQUARTERS}

for

\section{FANCY SWEET PEAS}

Spencer Varieties in Separate Colors and Mixtures (See Page 33 of Catalogue)

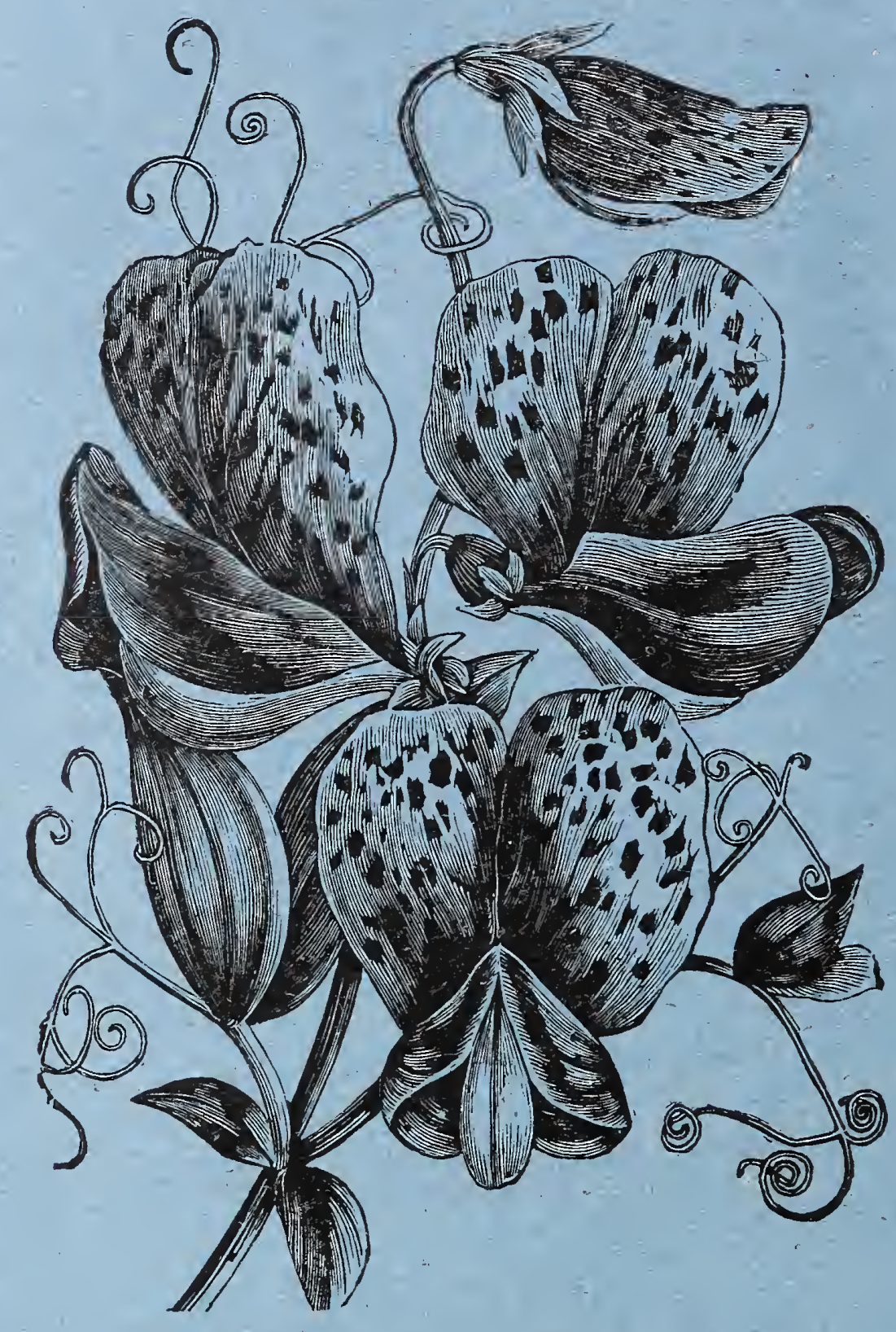

WE ALSO HAVE

A Complete Line of Poultry Supplies

At Our City Salesroom, Corner 15th and Howard Street Telephone ATlantic 1739

THE NEBRASKA SEED CO.

General Office and Warehouse: 1208-10-12-14 Jones Street

OMAHA, NEBRASKA 